July 1999 • NREL/SR-500-24663

\title{
Performance and Economics of a Wind-Diesel Hybrid Energy System: Naval Air Landing Field, San Clemente Island, California
}

Ed McKenna

National Renewable Energy Laboratory Golden, Colorado

Timothy L. Olsen

Tim Olsen Consulting

Denver, Colorado

(2)

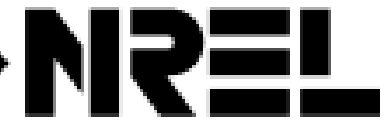

National Renewable Energy Laboratory

1617 Cole Boulevard

Golden, Colorado 80401-3393

NREL is a U.S. Department of Energy Laboratory

Operated by Midwest Research Institute $\bullet$ Battelle $\bullet$ Bechtel

Contract No. DE-AC36-98-G010337 
July 1999 • NREL/SR-500-24663

\section{Performance and Economics of a Wind-Diesel Hybrid Energy System: Naval Air Landing Field, San Clemente Island, California}

DOE Strategic Environmental Development Research Program

Ed McKenna

National Renewable Energy Laboratory Golden, Colorado

Timothy L. Olsen

Tim Olsen Consulting

Denver. Colorado

NREL Technical Monitor: Ed McKenna

Prepared under Subcontract No. CAK-6-15387-01

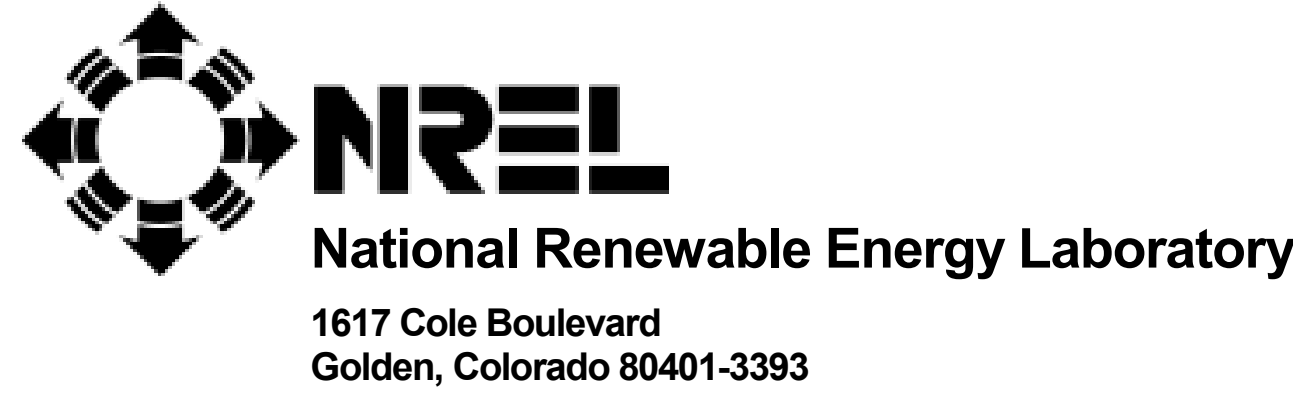

NREL is a U.S. Department of Energy Laboratory Operated by Midwest Research Institute $\bullet$ Battelle $\bullet$ Bechtel Contract No. DE-AC36-98-G010337 


\section{NOTICE}

This report was prepared as an account of work sponsored by an agency of the United States government. Neither the United States government nor any agency thereof, nor any of their employees, makes any warranty, express or implied, or assumes any legal liability or responsibility for the accuracy, completeness, or usefulness of any information, apparatus, product, or process disclosed, or represents that its use would not infringe privately owned rights. Reference herein to any specific commercial product, process, or service by trade name, trademark, manufacturer, or otherwise does not necessarily constitute or imply its endorsement, recommendation, or favoring by the United States government or any agency thereof. The views and opinions of authors expressed herein do not necessarily state or reflect those of the United States government or any agency thereof.

Available to DOE and DOE contractors from:

Office of Scientific and Technical Information (OSTI)

P.O. Box 62

Oak Ridge, TN 37831

Prices available by calling 423-576-8401

Available to the public from:

National Technical Information Service (NTIS)

U.S. Department of Commerce

5285 Port Royal Road

Springfield, VA 22161

$703-605-6000$ or $800-553-6847$

or

DOE Information Bridge

http://www.doe.gov/bridge/home.html

Printed on paper containing at least $50 \%$ wastepaper, including $20 \%$ postconsumer waste 


\section{CONTENTS}

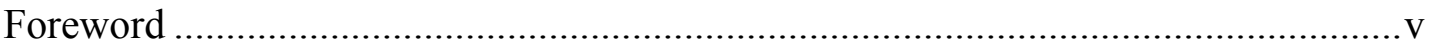

Acknowledgments .........................................................................................

Executive Summary ........................................................................................ vii

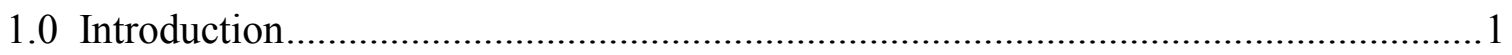

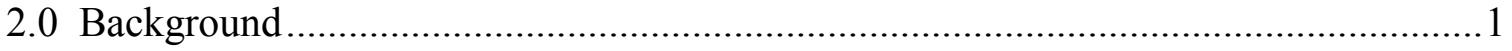

2.1 San Clemente Island ....................................................................... 1

2.2 Naval Installation Mission ......................................................................... 2

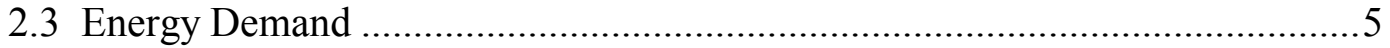

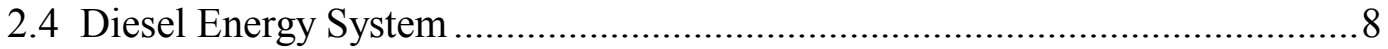

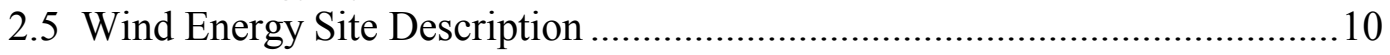

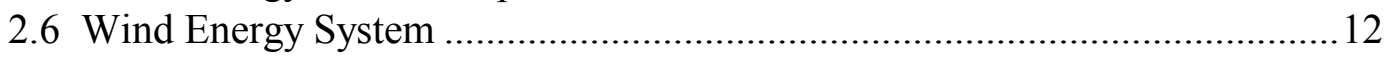

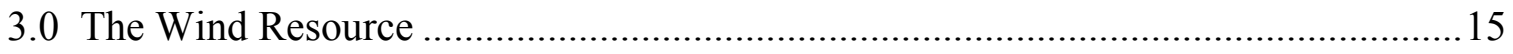

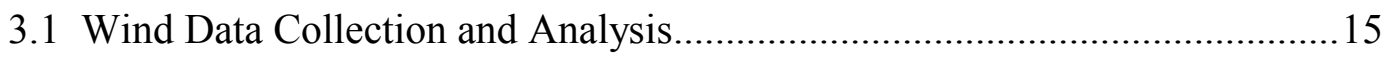

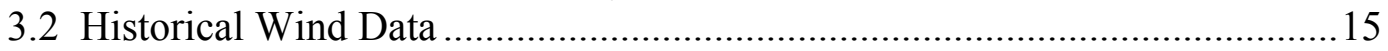

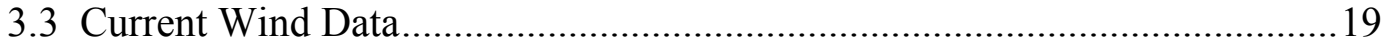

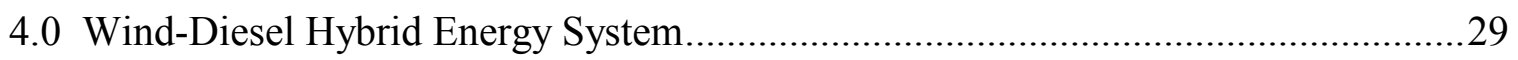

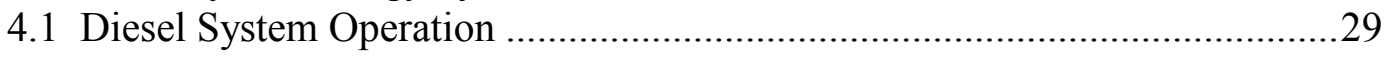

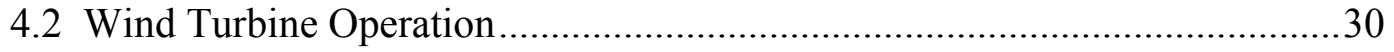

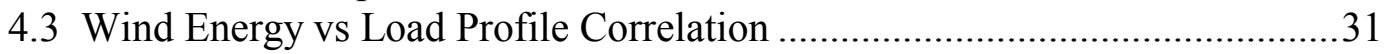

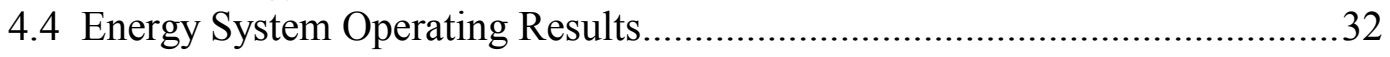

4.5 Hybrid System Spreadsheet Model.......................................................... 32

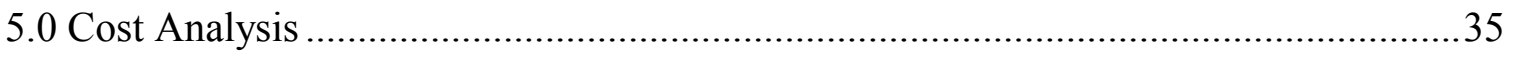

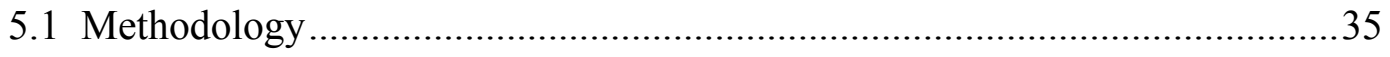

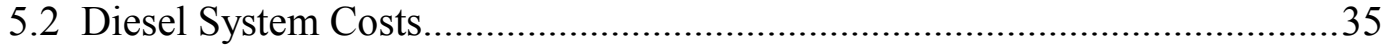

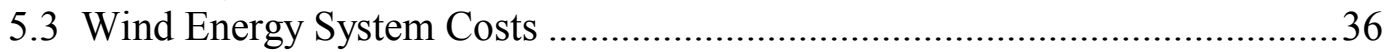

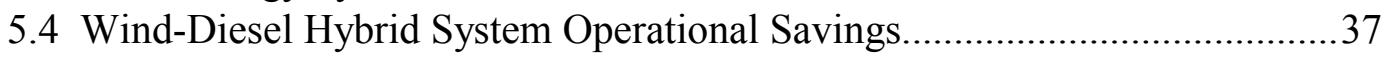

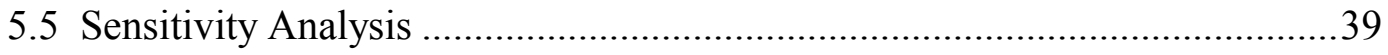

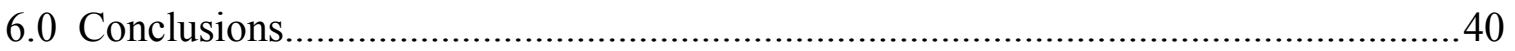

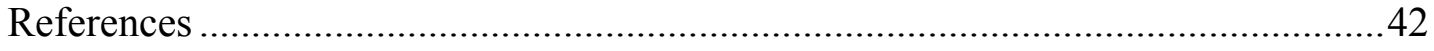

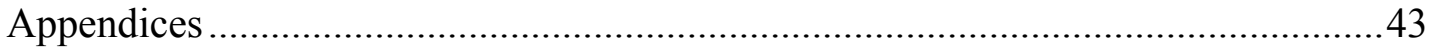

A. Hybrid System Model and Economic Summary Tables

B. SCI 1998-9 Power Plant Status and Production Reports

C. Independent Paper on Wind-Diesel Hybrid Energy System Design and Operation

D. Wind-Diesel System Operational Guidelines 


\section{LIST OF TABLES}

$\underline{\text { Page }}$

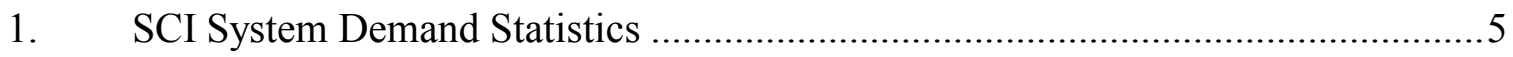

2. Diesel / Generator Power Rating and Fuel Consumption...................................9

3. Source Years for Composite Wind Data Set ................................................... 19

4. Summary of Current SCI Meteorological Data ...............................................19

5. 1998 Hybrid Systems vs Baseline: Spreadsheet Model Results ..........................34

6. Initial Capital Costs for One Additional $225 \mathrm{~kW}$ Wind Turbine.........................36

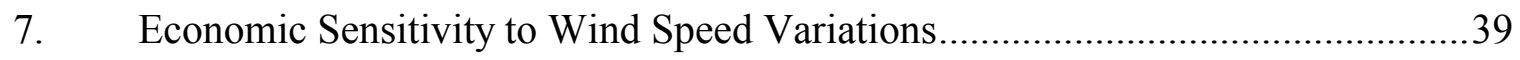




\section{LIST OF FIGURES}

$\underline{\text { Page }}$

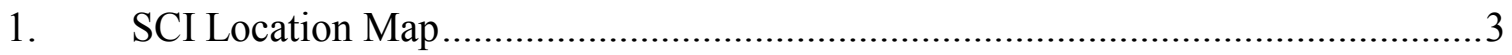

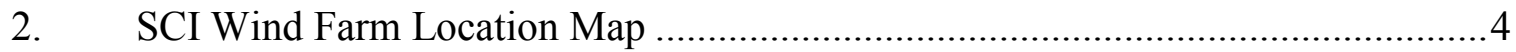

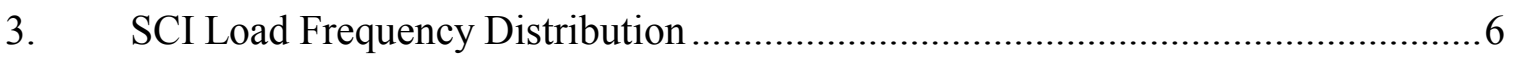

4. SCI Annual Average Diurnal Load....................................................................6

5. SCI Annual Energy Production Record ..............................................................

6. SCI Annual Fuel Consumption Record ..........................................................

7. SCI Energy Production vs Fuel Consumption ..................................................

8. SCI Naval Facilities and SERDP Wind Farm Site ...............................................11

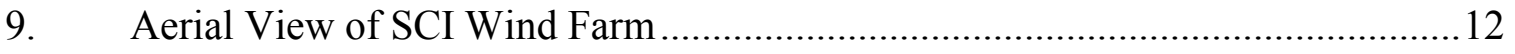

10. SCI SERDP-Funded NM 225-30 (225 kW) Wind Turbines ..............................14

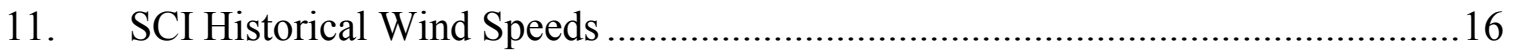

12. Annual Average Diurnal, Jacobs Site, 1983-4 ...................................................17

13. Annual Average Diurnal, Jacobs Site, 1984-5 ....................................................18

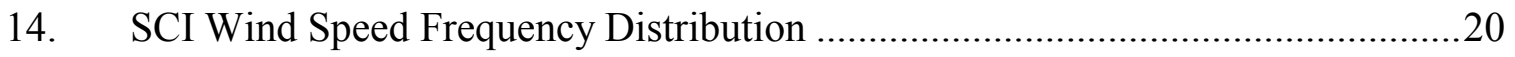

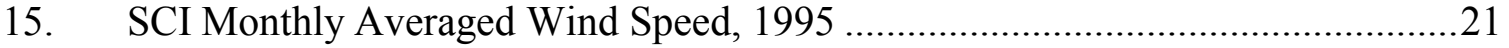

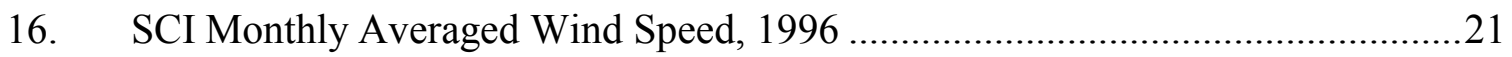

17. SCI Monthly Averaged Wind Speed, 1997 ......................................................22

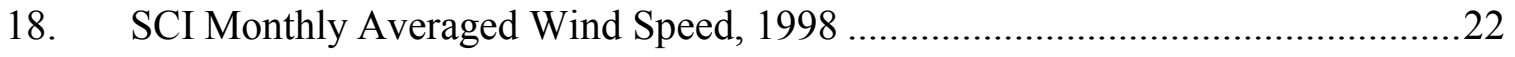

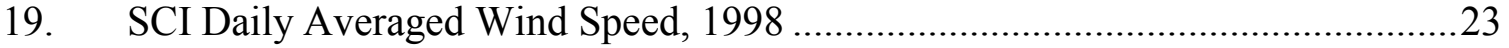

20. SCI Monthly Averaged Temperature, 1998 .........................................................23

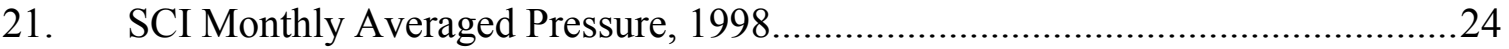

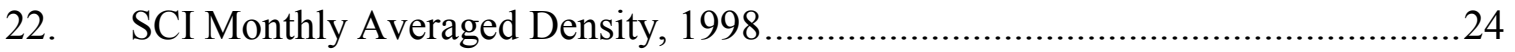


23. SCI Monthly Averaged Wind Power Density, 1998.......................................25

24. SCI Annual Average Diurnal Wind Speed ...................................................26

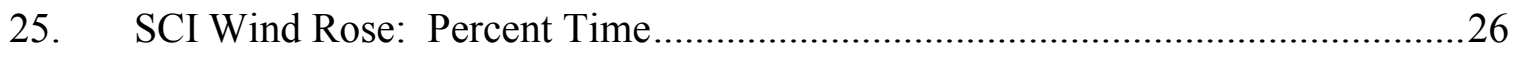

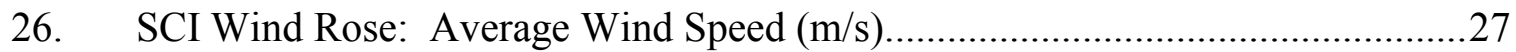

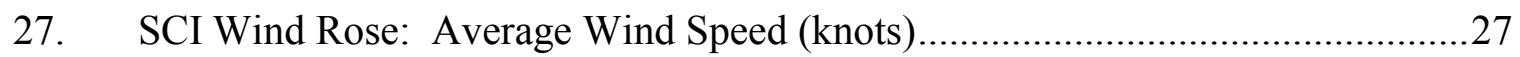

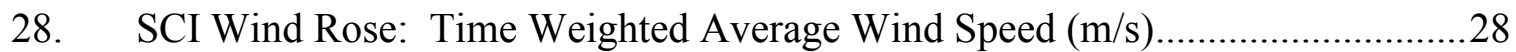

29. SCI Wind Rose: Time Weighted Average Wind Speed (knots).........................28

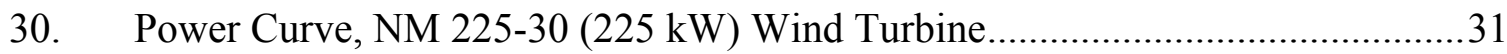

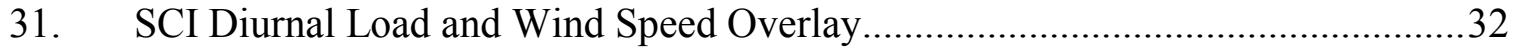

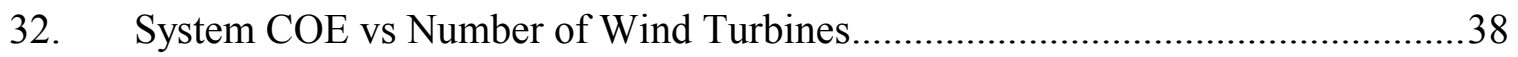

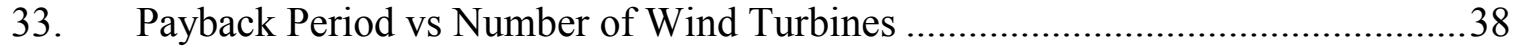

34. Internal Rate of Return vs Number of Wind Turbines ......................................39 


\section{FOREWORD}

This report was prepared as an account of work for others funding contract, sponsored by the Department of Defense (DoD) Strategic Environmental Research and Development Program (SERDP) under Department of Energy (DOE) Contract \# DE-AC02-83CH10093.

This report provides an overview of the wind resource, economics and operation of the recently installed wind turbines in conjunction with the with diesel power for the Naval Air Landing Field (NALF), San Clemente Island (SCI), California Project.

The purpose of the SERDP and Federal Energy Management Program (FEMP) funded installation is to use wind power, a form of renewable energy, to decrease the Navy's dependency on fossil fuel at San Clemente Island. Wind-powered electrical generation would allow a reduction in the current use of diesel-powered generators on the island. The primary goal of the SCI wind power system is to operate with the existing diesel power plant and provide equivalent or better power quality and system reliability than the existing diesel system. The wind system is intended to reduce, as far as possible, the use of diesel fuel and the inherent generation of nitrogen-oxide emissions and other pollutants.

The first two NM 225/30 225kW wind turbines were installed and started shake-down operations on February 5, 1998. This report describes the initial operational data gathered from the February through January 1999, as well as the SCI wind resource and initial cost of energy provided by the wind turbines on SCI. In support of this objective, several years of data on the wind resources of San Clemente Island was collected and compared to historical data. The wind resource data was used as input to economic and feasibility studies for a wind-diesel hybrid installation for San Clemente Island.

Timothy L. Olsen, an engineering consultant, was contracted by National Renewable Energy Laboratory (NREL) to assist with data reduction analysis, research historical wind resource data, perform wind-diesel hybrid analysis, and assist in the generation of this report. 


\section{ACKNOWLEDGMENTS}

The authors wish to acknowledge major contributions to the success of this project by the following people: Ed Cannon of National Renewable Energy Laboratory (NREL), the Strategic Environmental Research and Development Program (SERDP) project manager, and Neil Kelley of NREL, the meteorological consultant. Bob Keller and crew of Mountain Valley Energy, who installed, commissioned, and helped operate the meteorological towers and instrumentation. Extensive typing, editing, and graph building was provided by Roni Olsen of Highline Editions.

Scott Davis, the Utilities Supervisor at San Clemente Island (SCI), advised on aspects of SCI facilities, costs, operations, and detailed breakdowns for the SCI diesel plant operations and costs. Scott also manages daily wind energy project activities. More detailed diesel cost information was provided by Valre Kehler and Mike Stevens of Valley Detroit Diesel Allison. Additional support was provided by Brian Cable, the SCI project manager of Naval Facilities Engineering Service Center (NFESC); Ken Nicoll, past Division Director of Public Works Center (PWC); Diana Bendle, Assistant Operations PWC.

Tom Brule, Division Director at PWC San Diego, and Joyce Sengpaseuth, the electrical engineer at PWC San Diego made the site available for study and arranged travel to and from SCI. Scott Miller of NFESC assisted with meteorological instrumentation, and the rest of the SCI Navy support staff assisted with this project in countless ways. And yes, one other that kept the SCI Wind Energy dream alive - Norm Groth, USN COGEN-SD Director.

Each of these people deserves special thanks for their role in bringing this project together. 


\section{EXECUTIVE SUMMARY}

In 1991, Congress authorized the Strategic Environmental Research and Development Program (SERDP) to help Department of Defense (DoD) meet their environmental obligations. The SERDP efforts included the use of alternative energies to reduce emissions.

The long-term objectives of the U.S. Navy for San Clemente Island (SCI) are to install about 8 MW of wind capacity and to develop a pumped-hydroelectric storage system, using the ocean as the lower reservoir. SCI's electrical system is powered with diesel generators, using wind energy to reduce the overall diesel system operating costs.

To accomplish this mission, National Renewable Energy Laboratory (NREL), with the aid of Naval Facilities Engineering Service Center (NFESC), was charged with collecting wind resource data, and then providing the wind turbine generation system installations. The first two turbine installations were funded through DOE/SERDP, the third is being funded by the Department of Energy (DOE) Federal Energy Management Program (FEMP) funds, and the fourth will be funded through DoD Navy funds. This report summarizes the results of those tasks and the operational data learned to date.

The 1995 through 1998 wind resource at the designated SCI Wind Turbine Site has an annual average wind speed of $6.1 \mathrm{~m} / \mathrm{s}$ (11.8 knots) as measured by NREL and NFESC on a $42.7 \mathrm{~m}$ (140 foot) meteorological tower. Data were collected between August 1995 and January 1999 with several sections missing throughout.

This work presents a study of the operation of a wind-diesel hybrid system using two wind turbines, along with predictions for an expansion up to 4 wind turbines. The study shows that wind energy can be cost effective in this application. As the third and fourth wind turbines are added, further savings are expected as the power plant can then run with fewer or smaller diesel engines. Further additions would start to see diminishing savings. Additional wind turbine installations may be limited at SCI, as the island has 7000 protected archeological sites and other Navy facilities have priority. Higher wind potential is available at the southeast end of the island, but that region is used for the bombing range and is off limits.

Using two $225 \mathrm{~kW}$ wind turbines, the wind energy COE of $\$ 0.142 / \mathrm{kWh}$ helps reduce the winddiesel hybrid system COE from the baseline $\$ 0.476 / \mathrm{kWh}$ to $\$ 0.461 / \mathrm{kWh}$. This reduces system COE by $3.2 \%$. The payback period is 6.5 years, the internal rate of return $14.4 \%$. The four-turbine case had a wind energy COE of $\$ 0.139 / \mathrm{kWh}$ and a hybrid system COE of $\$ 0.447 / \mathrm{kWh}$, saving $6.1 \%$. The payback period is 6.3 years, the internal rate of return $14.8 \%$. The COE for this case is relatively insensitive to annual average wind speed, varying $2.6 \%$ for a $17.5 \%$ change in wind speed. But the payback period is quite sensitive to wind speed, varying $28 \%$ to $63 \%$ for a $17.5 \%$ change in wind speed.

As a preliminary review, this study used 1-hour average wind and load data for the hybrid system modeling to develop a general sense of economic tradeoffs. Dynamic load management should be addressed using load and wind data at shorter intervals (1 minute or less) to study system dynamics. 


\subsection{INTRODUCTION}

This report outlines and summarizes the local wind resource and evaluates the costs and benefits of supplementing the current diesel-powered energy system with wind turbines at the Naval Auxiliary Landing Field, San Clemente Island, California. This renewable electrical power generation provides a reduction of emissions from the diesel power plant. Specifically, the project began with two operational $225 \mathrm{~kW}$ wind turbines, and construction has begun on a third turbine, which should be installed and online by July, 1999.

In Section 2.0 the San Clemente Island (SCI) site, naval operations, and current energy system are described, as are the data collection and analysis procedures. Section 3.0 presents the wind resource data and its analysis results, including historical wind speed averages, recent annual records, diurnal wind speeds, and annual wind roses. Sections 4.0 and 5.0 present the conceptual design and cost analysis of a hybrid wind and diesel energy system on SCI, with conclusions following in Section 6. Appendix A presents summary pages of the hybrid system spreadsheet model. Appendix B contains actual system operating data. Appendix $C$ presents the results of a preliminary load and fuel analysis. Appendix D presents Wind-Diesel System Operational Guidelines developed by NREL and the RMH Group (Lakewood, Colorado).

\subsection{BACKGROUND}

\subsection{San Clemente Island}

\section{Installation Setting}

SCI is one of the Navy's largest real estate assets and is among its most unique installations. SCI is the southernmost of the eight Channel Islands located off the southern California coast, lying approximately $89 \mathrm{~km}(55 \mathrm{mi})$ southwest of Long Beach and $135 \mathrm{~km}(84 \mathrm{mi})$ northwest of San Diego. The next nearest land-mass to SCI is Santa Catalina Island, lying approximately $40 \mathrm{~km}(25$ $\mathrm{mi}$ ) away between SCI and the mainland. SCI's geographical center is $32^{\circ} 54^{\prime} \mathrm{N}, 118^{\circ} 29^{\prime} \mathrm{W}$.

The Island is approximately $34 \mathrm{~km}(21 \mathrm{mi})$ in length, with a land area of about $148 \mathrm{~km}^{2}\left(57 \mathrm{mi}^{2}\right.$, or 35,540 acres), making it one of the larger Channel Islands shown in Figure 1. The rugged southern third of the island has an average width of about $6.4 \mathrm{~km} \mathrm{(4} \mathrm{mi),} \mathrm{with} \mathrm{the} \mathrm{remainder} \mathrm{tapering} \mathrm{to} 1.6$ $\mathrm{km} 1(\mathrm{mi})$ across at the flatter and lower north end.

SCI is considered the most biologically and historically distinctive coastal island owned by the United States. Because the island supports unique natural, cultural, and anthropologic resources as well as a variety of activities for Naval operations and training.

The island, generally treeless, is relatively flat on top and drops off sharply on the east side with a more gradual slope to the ocean on the west side. The interior terrain is a rolling mesa, with little vegetation, mostly coarse grasses and few large shrubs. Its highest point, Vista View Point, is 592 $\mathrm{m}(1,943$ feet $)$ at the southwestern portion of SCI. 
The San Clemente Island wind turbine site, Figure 2, is located along Telemetry Road in the island's north-central portion ( $\left.33^{\circ} 59^{\prime} \mathrm{N}, 118^{\circ} 53^{\prime} \mathrm{W}\right)$.

Prevailing winds on SCI are from the west and northwest and are moderate and steady most of the year. The average wind speed at the wind turbine site is $6.1 \mathrm{~m} / \mathrm{s}(11.8 \mathrm{knots})$ and seasonal variation is small.

\section{Climate}

SCI's climate is distinctly maritime, with cool summers and mild winters. Except for fog and overcast conditions and generally cooler year-round temperatures, the weather is similar to that of the southern California mainland coastal region [1].

\section{Temperature}

One of the outstanding features of SCI's climate is the narrow temperature range, with mean winter temperature just $-12.2^{\circ} \mathrm{C}(10 \mathrm{~F})$ lower than the mean summer temperature. Mean annual temperature at the lower elevations is about $15.6^{\circ} \mathrm{C}\left(60^{\circ} \mathrm{F}\right), 16.6^{\circ} \mathrm{C}\left(62^{\circ} \mathrm{F}\right)$ at the higher elevations. Temperatures above $32.2^{\circ} \mathrm{C}\left(90^{\circ} \mathrm{F}\right)$ are rare, but occasionally when Santa Ana wind conditions occur between August and October, temperatures of $32.2^{\circ} \mathrm{C}\left(90^{\circ} \mathrm{F}\right)$ and even $37.8^{\circ} \mathrm{C}\left(100^{\circ} \mathrm{F}\right)$ have been recorded. No temperatures below freezing have ever been recorded at the location of the air field station, but at the higher elevations such as Mt Thirst such temperatures appear to occur according to the Navy based public utility crews.

\section{Humidity}

High relative humidity is experienced throughout the year with an annual average of 78 percent. The exception occurs during Santa Ana conditions when the relative humidity is generally less than 25 percent [1].

\section{Winds}

Gale force winds are common at higher elevations during the winter, but are infrequent elsewhere on the Island. Average wind speeds measured at the airfield are less than ten knots. The airfield sits at a low elevation next to a rise in the land, which can deflect or shelter the wind.

\section{Precipitation}

Annual precipitation averages just five to eight inches, with the majority falling between November and April, and the driest period being June to September. Snowfall has been reported at the highest elevations on the Island, Mt. Thirst and Mt. Vista, but in minimal amounts. Occasionally small hail accompanies the passage of strong storm fronts [1].

\subsection{Naval Installation Mission}

The Naval Auxiliary Landing Field (NALF), SCI serves a variety of weapons research, development, testing and evaluation activities, and a number of military training functions as well. It is used primarily by several major Naval tenant commands, but is also used by research divisions of government agencies and private companies working on government contracts. The Island is 
administered by the Commanding Officer, Naval Air Station North Island. SCI's relative isolation, restricted airspace, variable topography, adjacent deep seas and clear water conditions permit a great deal of flexibility in accommodating specific testing and training programs [1].

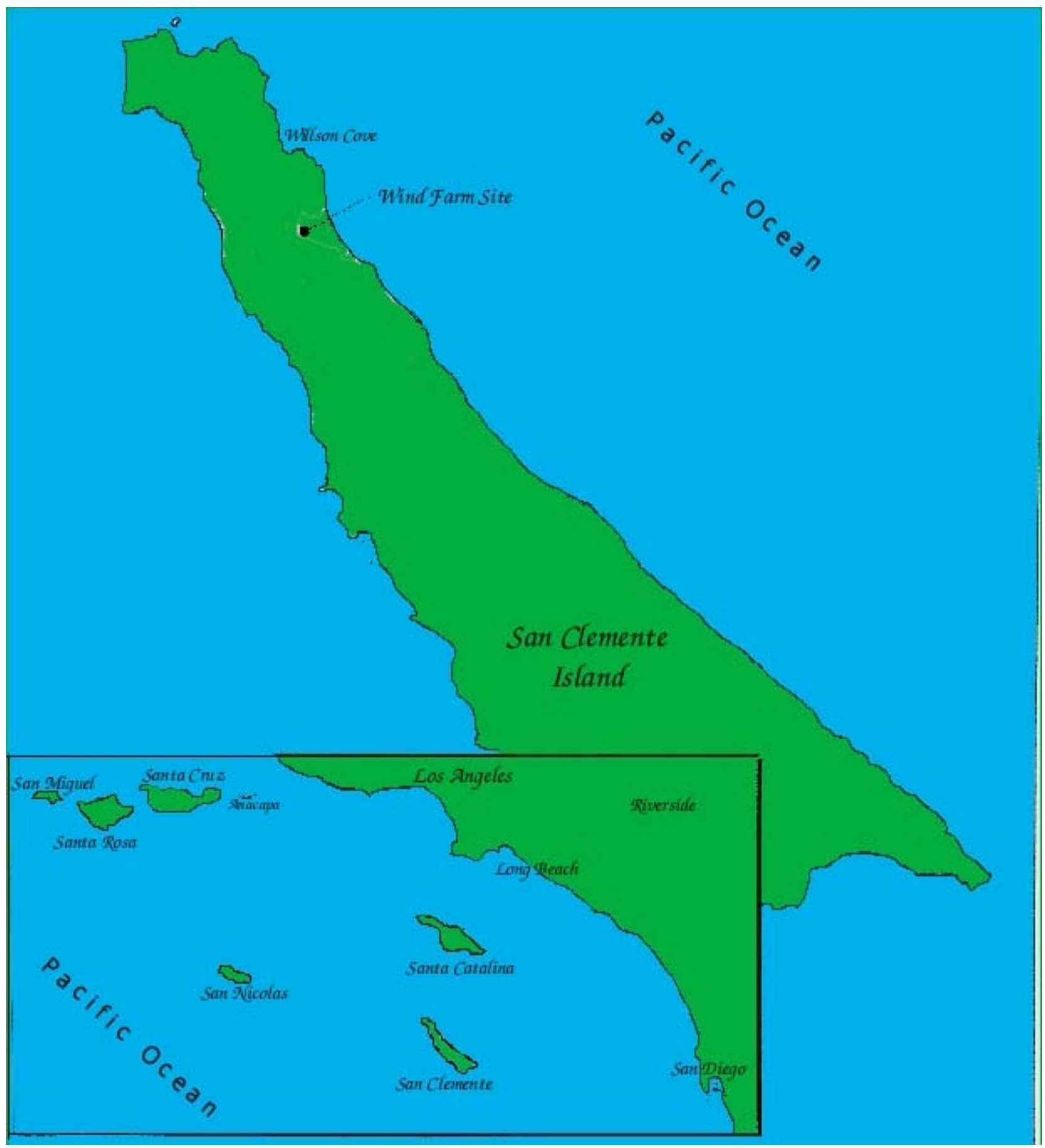

Figure 1: SCI Location Map

Source: San Clemente Island Site Manual 


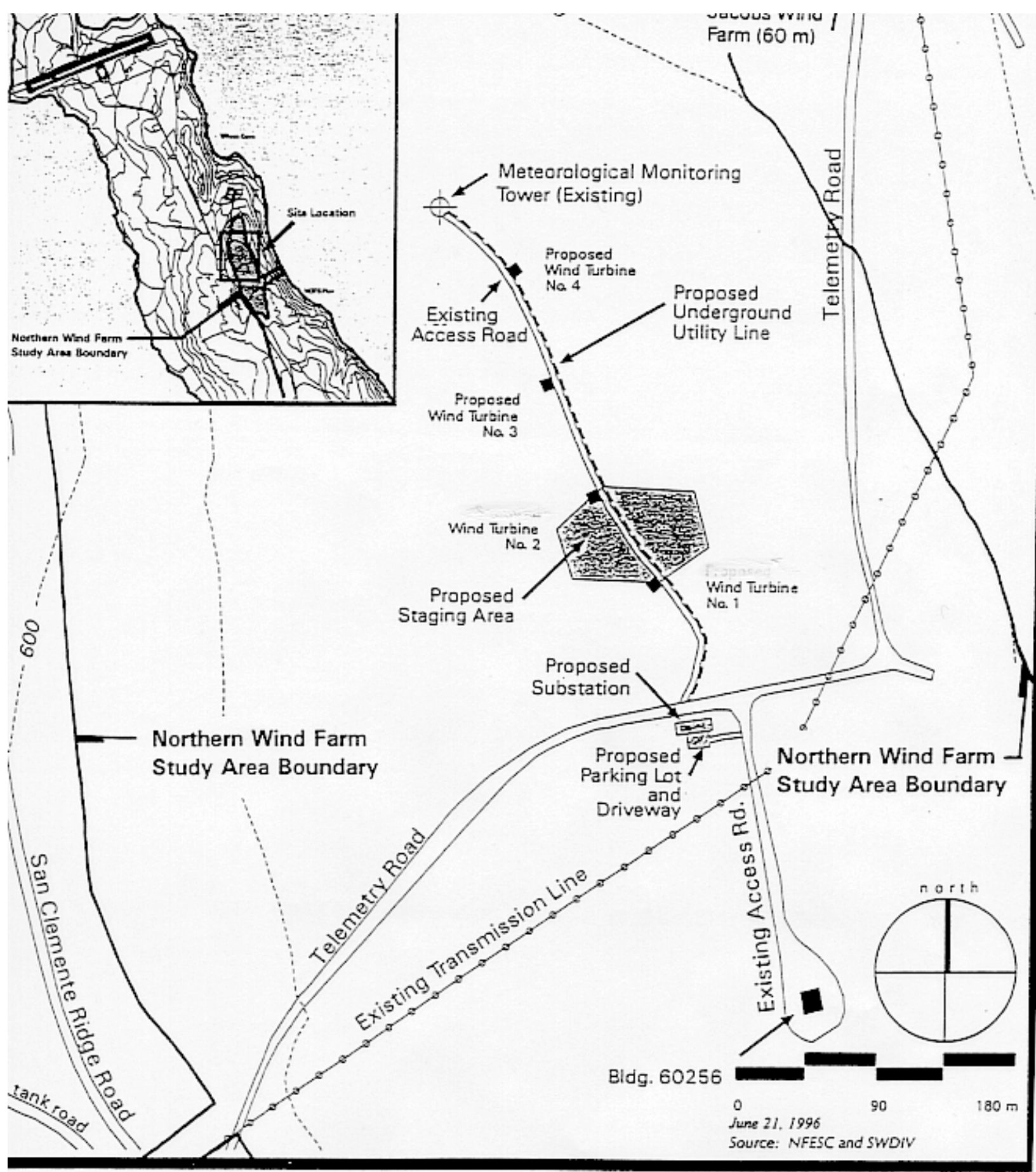

San Clemente Island SERDP Wind Farm Location of SERDP Wind Farm within Northern Wind Farm Study Area

Figure 2: SCI Wind Farm Location Map

Source: USN NFESC and SWDIV Environmental Assessment Report 


\subsection{Energy Demand}

Energy production information follows in Table 1. The current (1998) average hourly electrical demand at SCI is $846 \mathrm{kWh}$; the hourly average peak is $1350 \mathrm{~kW}$. The SCI electrical power system supplied 7.42 million $\mathrm{kWh}$ in 1998, up from 6.15 million $\mathrm{kWh}$ in 1996.

Table 1: SCI System Demand Statistics

\begin{tabular}{lrrrrr} 
& & & & & San Nicolas \\
Year & & 1996 & 1997 & 1998 & Island 1995 \\
\hline Peak daily demand & $(\mathrm{kWh})$ & 22,400 & 25,900 & 26,788 & $\mathrm{~N} / \mathrm{A}$ \\
Low daily demand & $(\mathrm{kWh})$ & 12,250 & 14,000 & 13,650 & N/A \\
Average hourly demand & $(\mathrm{kWh})$ & 711 & 785 & 846 & 771 \\
Average daily demand & $(\mathrm{kWh})$ & 17,075 & 18,838 & 20,320 & 19,275 \\
Average monthly demand & $(\mathrm{kWh})$ & 512,269 & 565,146 & 618,080 & 586,281 \\
Peak monthly demand & $(\mathrm{kWh})$ & 547,100 & 724,150 & 708,438 & $\mathrm{~N} / \mathrm{A}$ \\
Low monthly demand & $(\mathrm{kWh})$ & 478,000 & 523,250 & 578,025 & $\mathrm{~N} / \mathrm{A}$ \\
Annual energy production & $(\mathrm{kWh})$ & $6,147,230$ & $6,781,750$ & $7,416,959$ & $6,753,000$ \\
Annual energy from diesel $(\mathrm{kWh})$ & $6,147,230$ & $6,781,750$ & $6,631,021$ & $6,753,000$ \\
Annual fuel consumption & $(\mathrm{liter})$ & $1,983,120$ & $2,033,260$ & $2,074,240$ & $1,996,584$ \\
Annual fuel consumption & $(\mathrm{gal})$ & 523,942 & 537,190 & 547,958 & 527,499 \\
Energy / Fuel ratio & $(\mathrm{kWh} / \mathrm{l})$ & 3.10 & 3.34 & 3.58 & 3.38 \\
Energy / Fuel ratio & $(\mathrm{kWh} / \mathrm{gal})$ & 11.7 & 12.6 & 13.54 & 12.8 \\
Demand growth & $(\%)$ & - & 10.3 & 9.4 & -
\end{tabular}

Source: SCI Public Works Center

The load frequency distribution in Figure 3 shows predominant operation between $700 \mathrm{~kW}$ and $1000 \mathrm{~kW}$, with peaks up to $1400 \mathrm{~kW}$. Annual diurnal loads are shown in Figure 4. These figures are based on the composite data set using original 1998 loads data. Included with the data set are daily energy production and monthly fuel consumption. Annual records of monthly energy production and fuel consumption are shown in Figures 5 and 6, and the relationship between the two in Figure 7. 


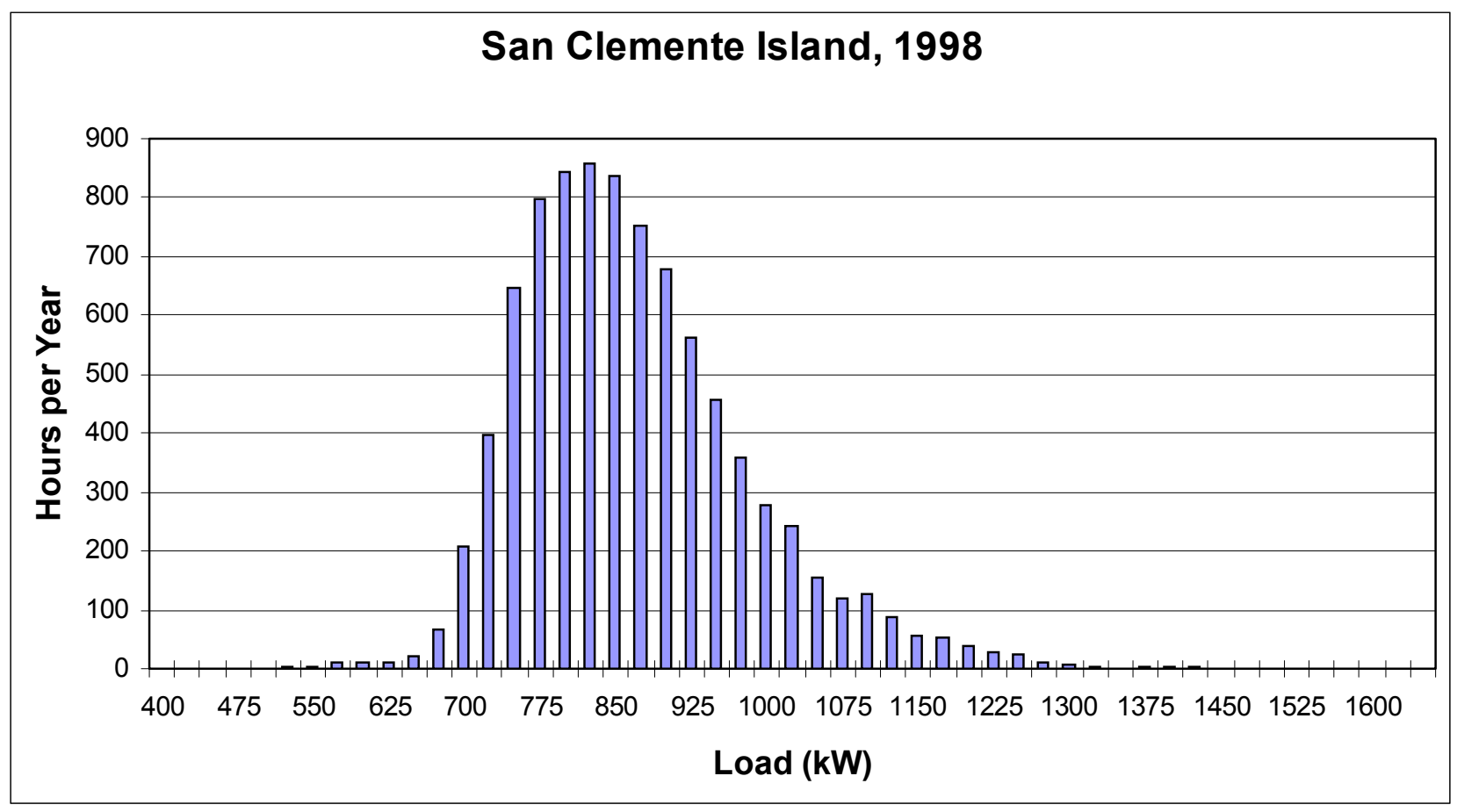

Figure 3: SCI Load Frequency Distribution

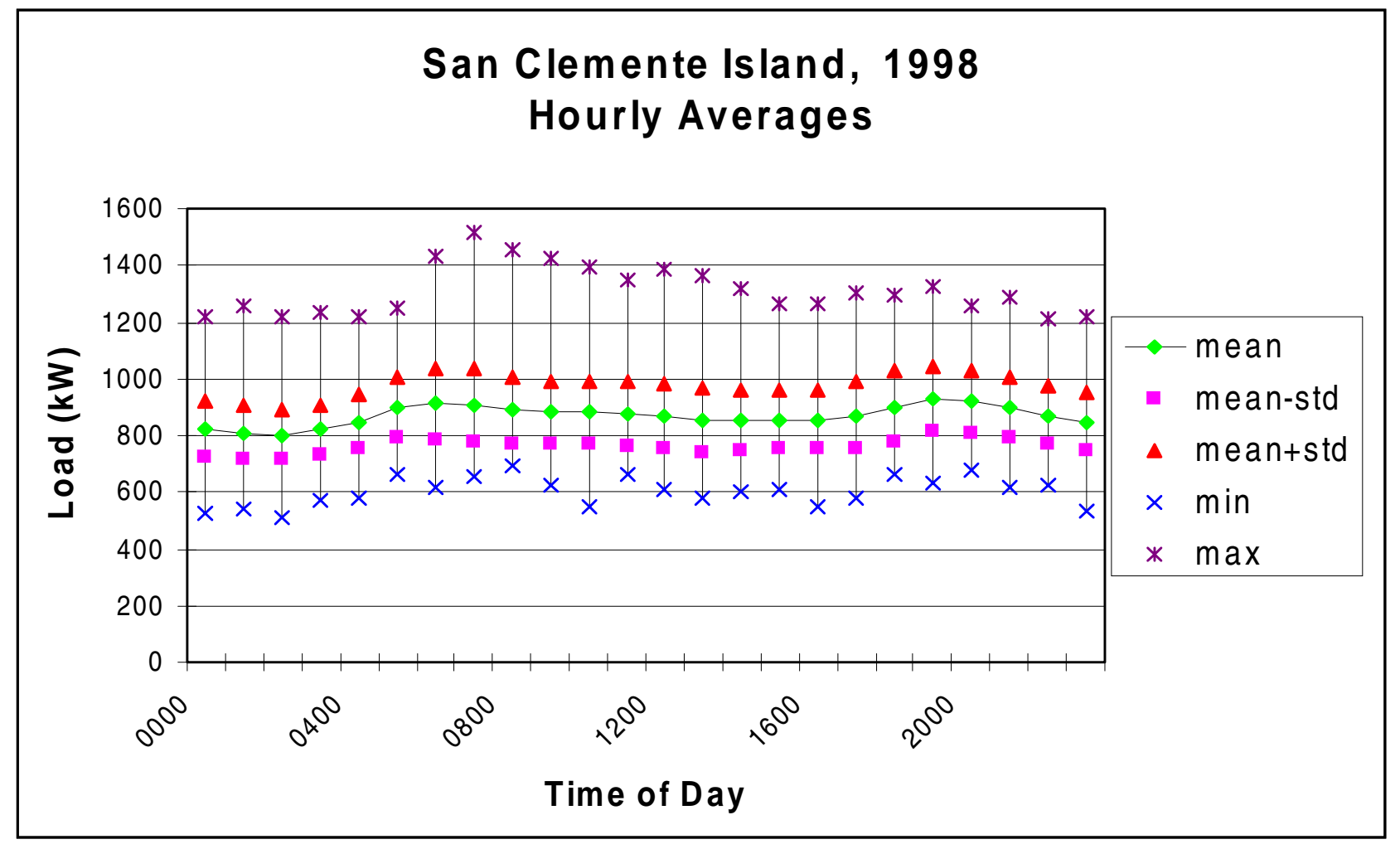

Figure 4: SCI Annual Average Diurnal Load 


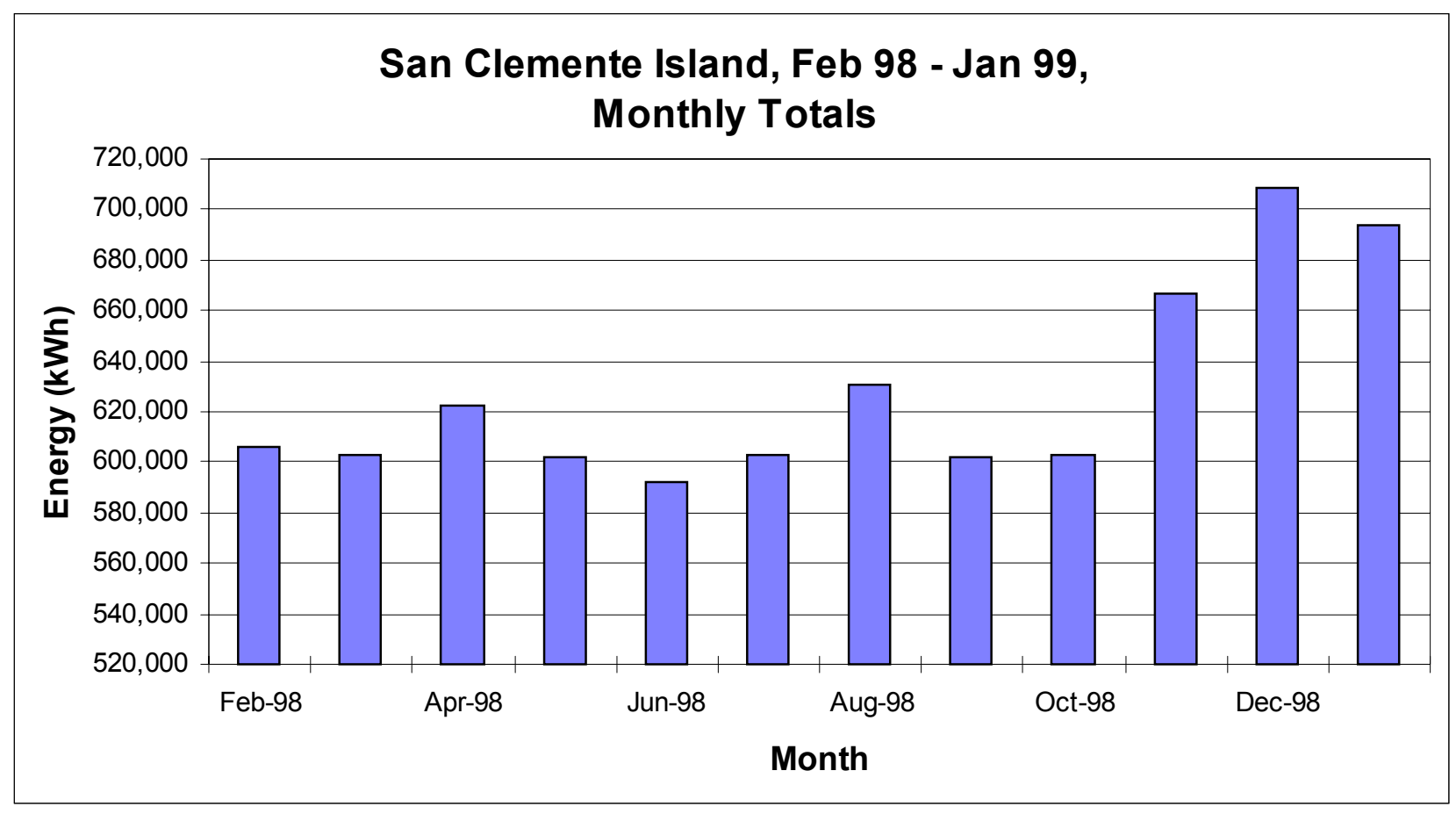

Figure 5: SCI Annual Energy Production Record

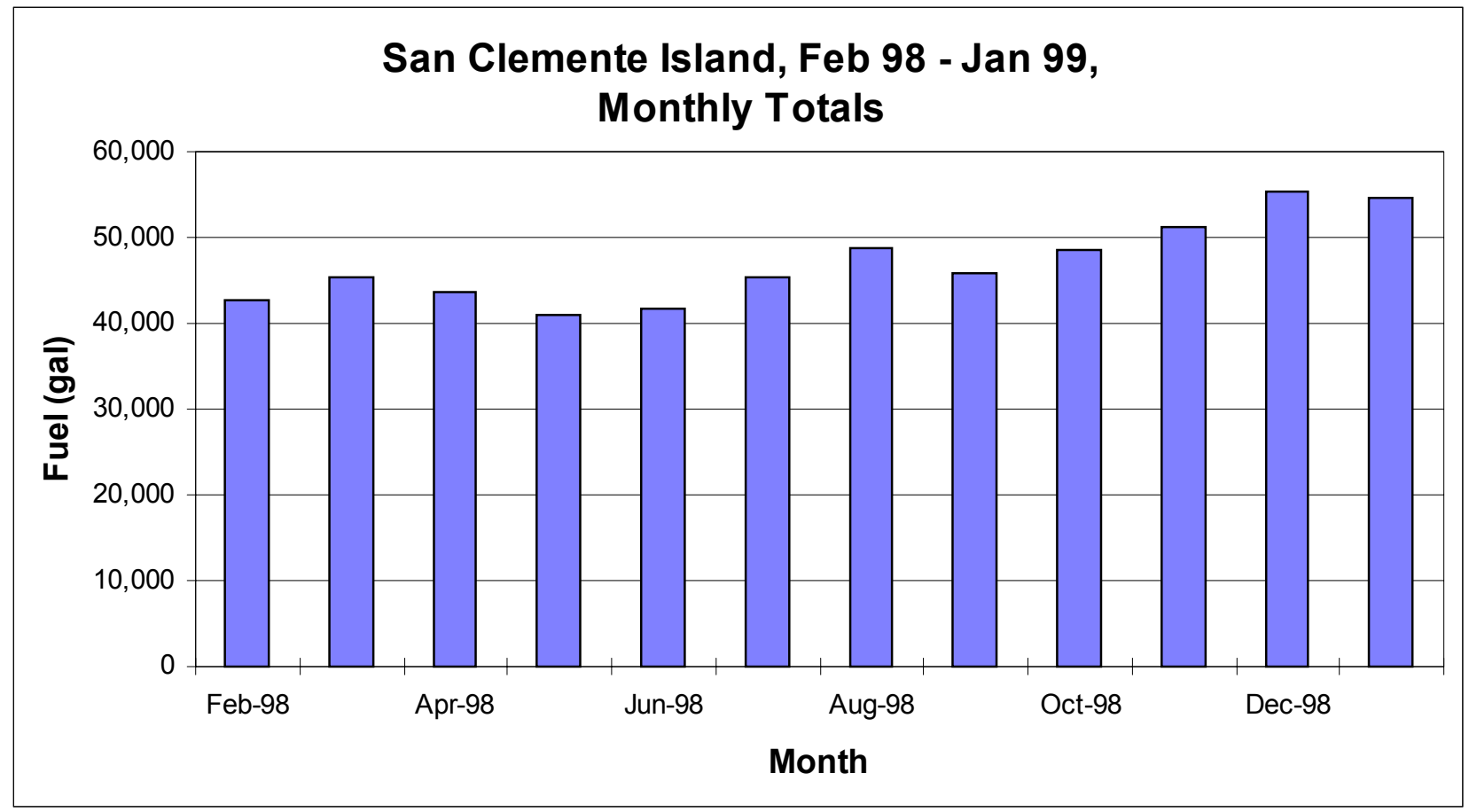

Figure 6: SCI Annual Fuel Consumption Record 


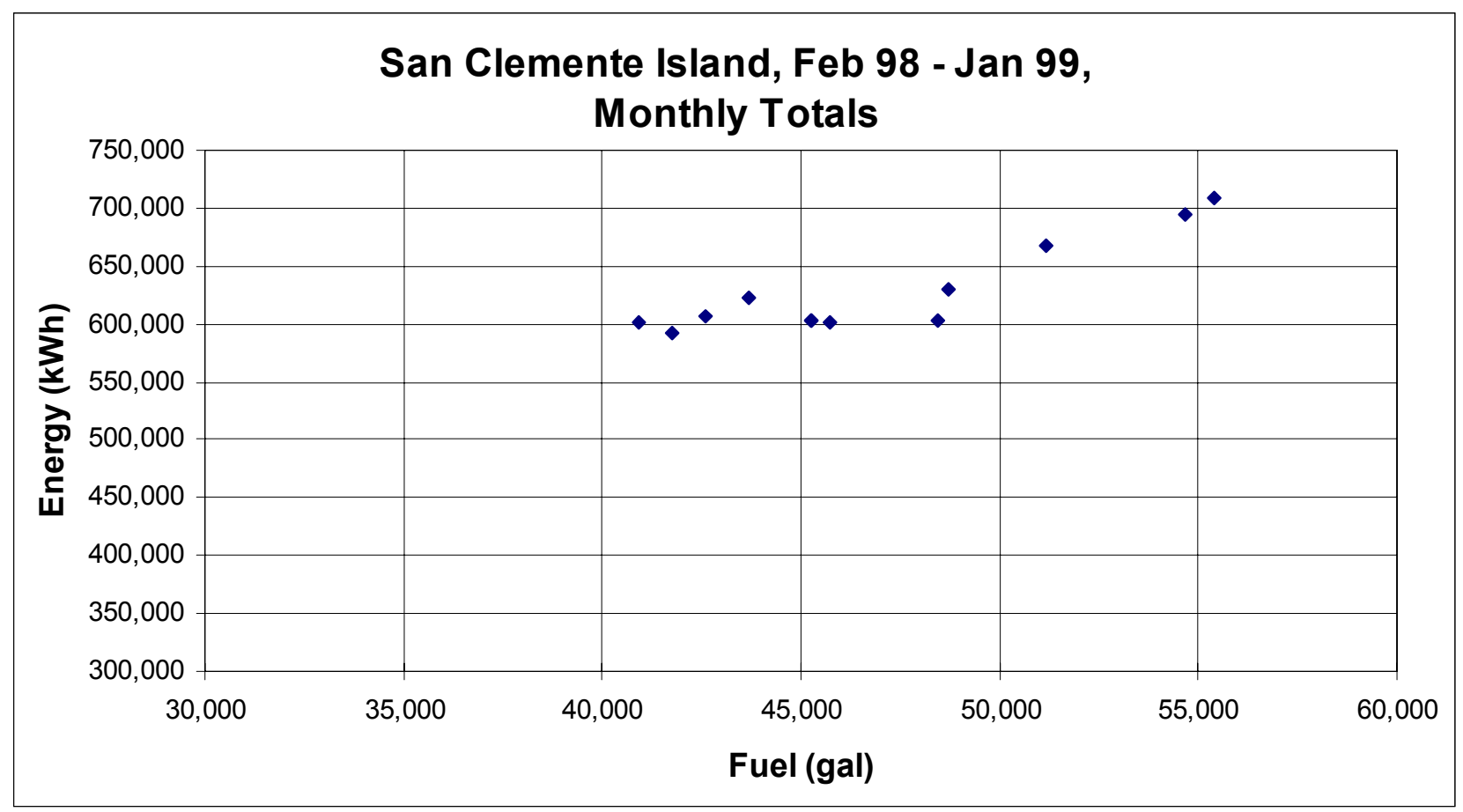

Figure 7: SCI Energy Production vs Fuel Consumption

\subsection{Diesel Energy System}

The existing SCI power plant consists of four diesel generators. The diesel generator plant is

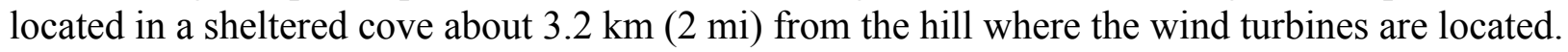
Power for the island grid is generated by diesel generators at 4,160 V and stepped up through two 2,000 KVA transformers to 12,470 VAC, three-phase, three-wire (Delta) for distribution on the island.

- The existing power plant and island power grid has the following electrical characteristics:

- Grid Voltage: $12.470 \mathrm{kV}$

- Frequency: $\quad 60 \mathrm{~Hz}+/-1.0 \mathrm{~Hz}$ (1998 PIE-NREL Data Record)

- Power Factor: $0.8-0.95$ lagging

- Average Load $846 \mathrm{~kW}$ (1998 SCI Data)

- Maximum Load 1350 kW (1998 SCI Data)

- Minimum Load $500 \mathrm{~kW}$ (1998 SCI Data)

Diesel Generator Sets: Electrical power at SCI is presently supplied by four Navy-owned, 3phase, $4160 \mathrm{~V}$, diesel driven electric generators that are operated by the Public Works Center located at San Diego. The diesel plant on the island was rebuilt in 1994 as Building 60137. The SCI operating data for 1998 shows an average diesel fuel consumption rate of $236.8 \mathrm{l} / \mathrm{h}$ (62.6 gph), and average energy conversion rate of $3.2 \mathrm{kWh} / 1(12.1 \mathrm{kWh} /$ gal, from Table 1$)$. The engines' specific diesel fuel rates are shown in Table 2. 
Table 2: Diesel / Generator Power Rating and Fuel Consumption

\begin{tabular}{llrr}
\multicolumn{2}{l}{ Manufacturer \& Model } & $\frac{\text { Power }}{\text { Rating }}$ & $\frac{\text { Fuel Usage }}{\text { Full Load }}$ \\
\hline Diesel & Generator & $\mathrm{kW}$ & $1 / \mathrm{hr}(\mathrm{gal} / \mathrm{hr})$ \\
\hline 1. EMD 8-645E1 & KATO (A258730000, 720 rpm) & 500 & $144(38)$ \\
2. EMD 8-645E1 & KATO (A258730000, 720 rpm) & 500 & $144(38)$ \\
3. EMD 12-645E4 & KATO (A257780001,720 rpm) & 1,200 & $329(87)$ \\
4. EMD 12-645E1 & KATO (A258710000,720 rpm) & 750 & $216(57)$
\end{tabular}

Unfortunately, there is little real data for the units operating at no load. The only information available is from EMD Power Products for its similar 12-cylinder, turbo-charged units during EMD factory testing. On units similar to 12-645E4, they recorded 57 liters per hour (15 gal per hour) at rated speed, no load. Based on this information, the hybrid system analysis presented later in this report uses a no-load consumption value of $17 \%$ of full load consumption. The other units probably would have no-load rates of $25 \%$ of full load, but the hybrid system model uses $17 \%$ because the turbo-charged unit is on the majority of the time.

In the current operating protocol, online diesel capacity typically exceeds average demand by a substantial margin to ensure enough capacity to cover excursions and to avoid too frequent switching between diesels. The resulting excess margin causes the diesels to run below their ratings most of the time, resulting in lower energy conversion efficiency. A tighter margin would allow more efficient operation but the more frequent switching would cause faster wear on the diesels and more work for the operators.

Fuel Supply System: Petroleum products are delivered to SCI by regularly scheduled barge and unloaded at Wilson Cove. Diesel fuel (DL-2) is delivered by barge to the fuel tank farm at the north end of Wilson Cove. Barges dispensing fuel tie up to a buoy and pump fuel directly into above-ground storage tanks. The DL-2 fuel is stored in the 37,854 liter (10,000 gal) above-ground tank located to the north of the power plant, Building 60137. Fuel is continuously circulated and centrifuged in this tank. Upon demand, fuel is automatically diverted from returning to the main storage tank and sent to day tanks located just outside the power plant instead. From the day tanks (one for each engine), fuel flows by gravity to each operating engine's fuel pump.

A 757 liter (200 gal) lubrication oil tank is located within Building 60137. Oil is added to each running engine via pumps or centrifuge. Each engine has a direct pipe connection to the lube oil centrifuge, and oil can be gravity-fed at this point or pumped in with pump 7 .

The plant is also provided with a waste-oil collection system. This system consists of one 1514 liter (400 gal) holding tank. The tank and pumps are located immediately outside the power plant and are equipped with secondary containment and interconnecting piping.

Balance of Plant: The plant is operated 24 hours per day. Operators observe equipment operation, make hourly log entries, and start and stop the generators as required. The control room has been 
recently upgraded and is enclosed by sound-reducing insulation and double doors leading to the engine room.

The station auxiliary equipment includes two $150 \mathrm{kVA}$, three-phase, 4160-120/208-V station service transformer, a $120 / 208-\mathrm{V}$ distribution panel board, a 20-battery $125-\mathrm{V}$ DC station battery bank, and two 2,000-kVA, three-phase, grounded-wye-delta-connected grounding transformers. There is one grounding transformer for each bus in the switchgear to provide a neutral for singlephase, $2400 \mathrm{~V}$-loads.

The power plant switchgear, installed in 1994, has two buses with a vacuum circuit-breaker tie. The circuit-breaker tie will trip automatically in the event of a fault on either bus.

In addition to the $4160-\mathrm{V}$ generators, local emergency generators provide back-up power for critical loads. The power is generated at utilization voltage $(120 / 208 \mathrm{~V}$ or $480 \mathrm{~V})$ and is applied to the load through manual or automatic transfer switches.

Distribution: Electricity is distributed throughout the island by three 12.4-kVA, 4160-V feeders. Feeder \# D-Line serves most of the southern end of the island. Feeder \# C-Line serves the northcentral area of the island, including personnel living facilities, administration and recreational facilities, and the public works buildings. Feeder \# A-Line serves the air terminal and associated hangars and maintenance facilities, and loads in the northwest part of the island.

The SCI Air Field portion of the distribution (feeder \# A-Line from pad A- 57-7) is completely underground. Feeders \# C-Line and \# D-Line use mostly overhead lines, consisting of wood poles supporting bare copper conductors.

\subsection{Wind Energy Site Description}

The wind energy site is located along Telemetry Road in its north-central portion $\left(33^{\circ} 59 \mathrm{~N}, 118^{\circ}\right.$ $53 \mathrm{~W}$ ), as shown in Figures 8 and 9. The highest elevation at this location is $222 \mathrm{~m}(730 \mathrm{ft})$.

The SERDP site is surrounded by, and dominated by, open, undeveloped habitats. The older wind farm that consisted of six Jacobs $20-\mathrm{kW}$ wind turbines is presently shut-down. It will be removed in 1999. It was constructed in 1987, and is positioned approximately $400 \mathrm{~m}(1312 \mathrm{ft})$ to the north of the current wind site at a lower elevation. Telemetry Road runs East-West through the wind site and a Navy building is located roughly $300 \mathrm{~m}(985 \mathrm{ft})$ to the south.

There are no trees or other wind obstructions on the site, just light vegetation including grasses and cacti. Several low water tanks and buildings, including the Power Plant Island Utilities, are located to the north and on lower elevations from the wind turbine site. The nearness of the power plant minimizes power line distances to the wind energy site.

This site has moderate winds throughout the year. Although more optimal wind site locations exist on the southern section of the island at higher elevations, this particular site was selected because it does not interfere with radar, communications, or other naval operations. It is close to the San 
Clemente Island power plant (approximately $4.3 \mathrm{~km}$ or $2 \mathrm{mi}$ ), and it does not pose environmental or anthropologic constraints or interfere with Naval Weapons Testing Operations.

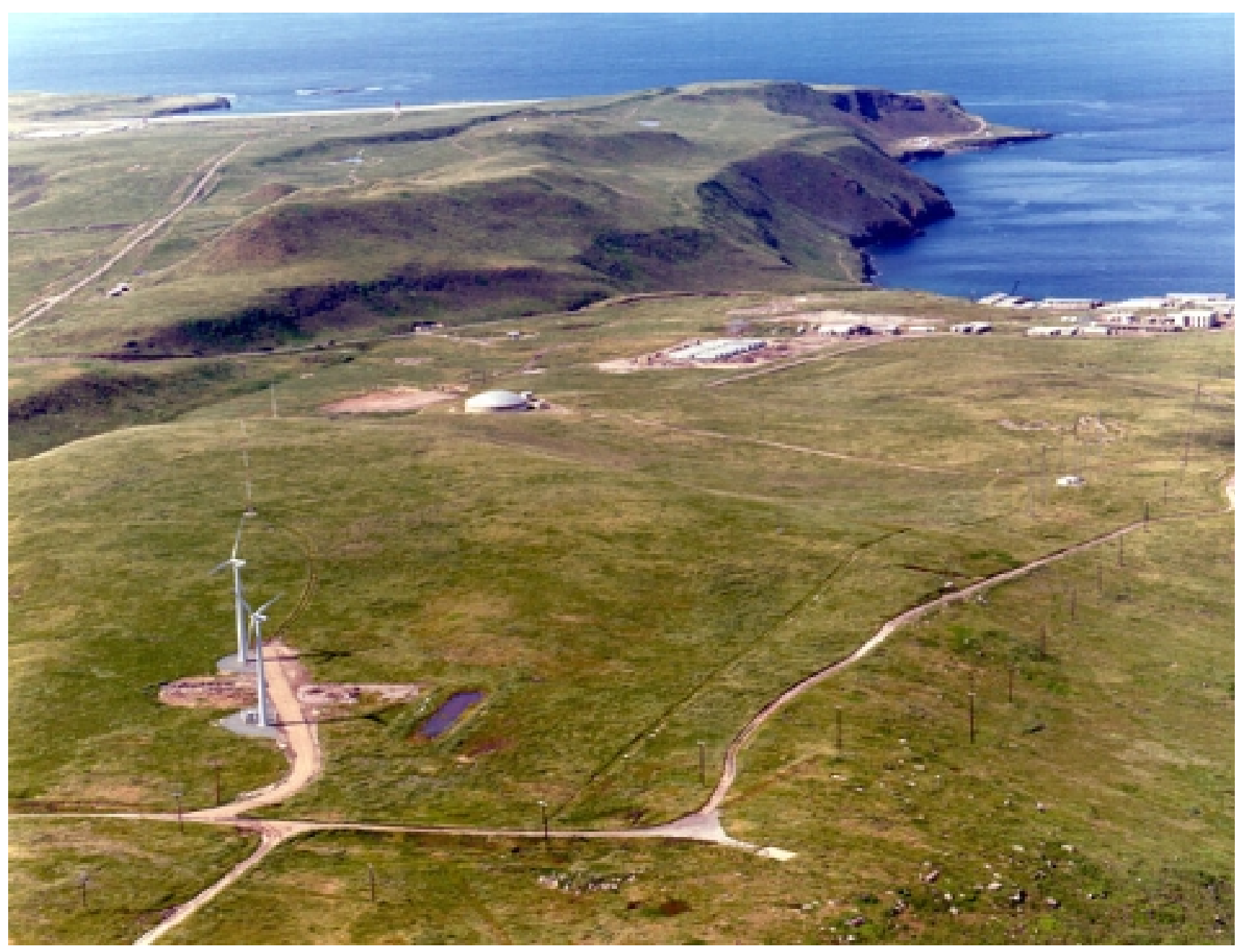

Figure 8: SCI Naval Facilities and SERDP Wind Farm Site Source: USN NFESC Aerial Photograph 


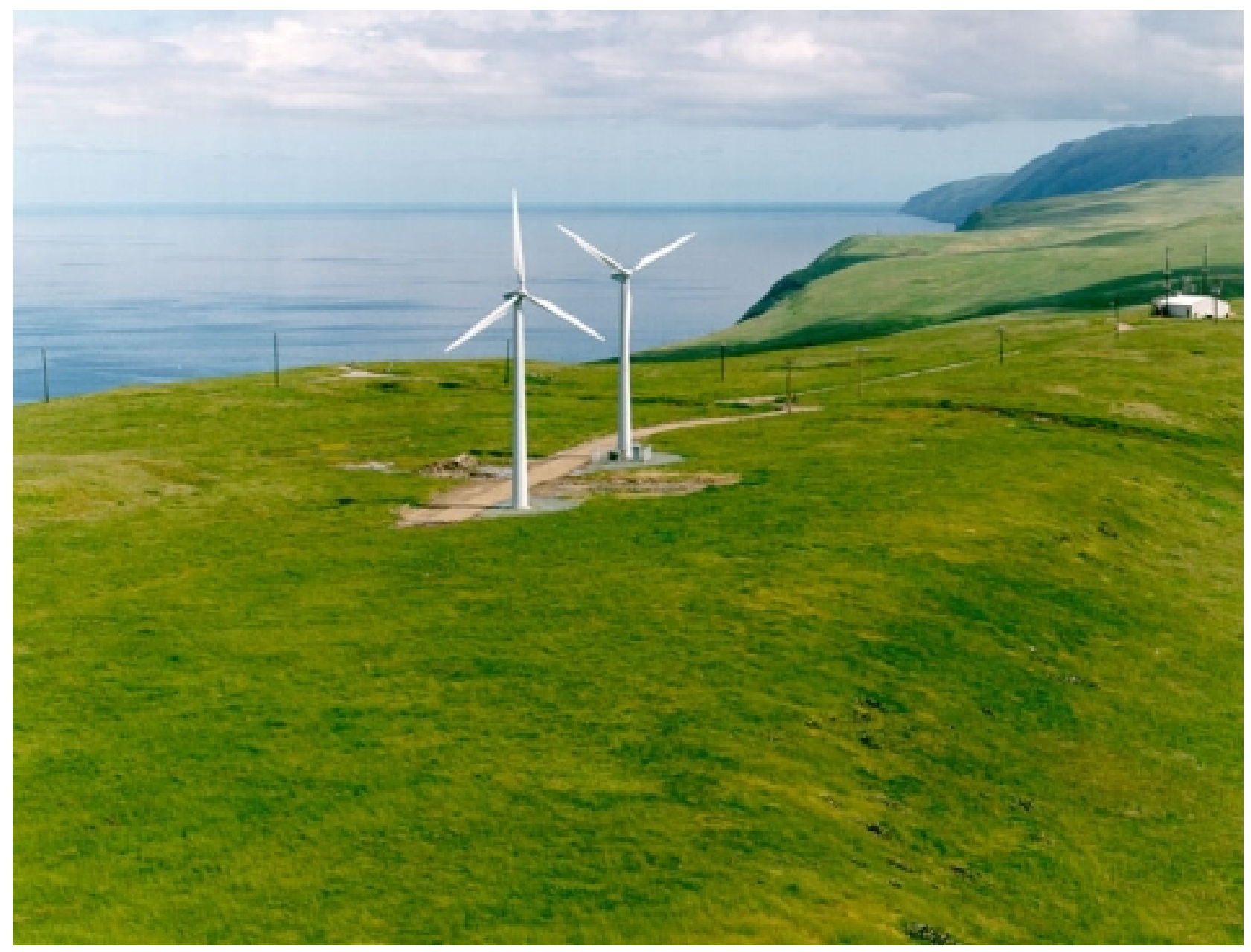

Figure 9: Aerial View of SCI Wind Farm

Source: USN NFESC Aerial Photograph

\subsection{Wind Energy System}

The wind turbine electrical power generation facility is composed of two NEG Micon Model 700225/40 wind turbines, now called the NM 225/30 model following the merger of Nordtank Energy Group and Micon. Shown in Figure 10, this wind turbine has a rotor area of approximately 700 square meters and a rated output of $225 \mathrm{~kW}$. (The new "30" designation in the model name of the turbine reflects the approximate diameter of the rotor measured in meters, instead of the lower generator rating). The wind turbines start producing power at approximately $4 \mathrm{~m} / \mathrm{s}(9 \mathrm{mph})$ and continue producing power up to $25 \mathrm{~m} / \mathrm{s}(56 \mathrm{mph})$.

Turbine \#1 is located at $32^{\circ} 59.147 \mathrm{~N}$ by $118^{\circ} 33.127 \mathrm{~W}$, Turbine \#2 is located at $32^{\circ} 59.211 \mathrm{~N}$ by $118^{\circ} 33.072 \mathrm{~W}$ and Turbine \#3 will be located nearby, all at $223 \mathrm{~m}(730 \mathrm{ft})$ altitude. The third $225-\mathrm{kW}$ wind turbine is under construction as this report is being written. 
Nacelle: The base frame is designed as a self supporting, integrated welded steel plate construction which also supports the main shaft bearing, gearbox, generator, yaw system, rotor, etc. The integrated construction is hot-dip galvanized and makes up the bottom half of the nacelle cover. The upper half is made from lighter, hot-dip galvanized steel plate.

Yaw System: The yaw system applies forced yaw by electrical gear drive over a cogged ball bearing ring with friction brake system.

Rotor: The rotor consists of three blades manufactured by LM, type LM 13.4, fastened to a hub. The blade diameter is $29.6 \mathrm{~m}(97.1 \mathrm{ft})$ with a swept area of $688 \mathrm{~m}^{2}\left(7407 \mathrm{ft}^{2}\right)$. The height to the blade tip in straight upright vertical position is $44.8 \mathrm{~m}(147.0 \mathrm{ft})$.

Tower: The tower height is $28.7 \mathrm{~m}$ ( $94.2 \mathrm{ft}$ ), with a hub height at the center of the rotor of $30.0 \mathrm{~m}$ $(98.4 \mathrm{ft})$. The tower weight is approximately $12,000 \mathrm{~kg}(26,455 \mathrm{lbm})$, and has three layers of zinc silicate for protection from the island's marine environment. (An alternative standard tower height for this turbine model provides a hub height of $36.0 \mathrm{~m}(118.1 \mathrm{ft})$, and is recommended for sites with a wind shear coefficient higher than 0.1.)

Wind Turbine Control: The main wind turbine control panel is located inside the tower bottom, protected against weather and unauthorized access. Its function is to provide automatic cut-in of the generator to the SCI electrical grid and fault detection and wind turbine protection. This control panel has easy access to operate and control the wind turbine. This controller has displays with fault indicators to secure quick fault finding in case of a turbine stop condition. If the SCI grid fails, and then is brought back on line the wind turbines can be automatically re-started. These wind turbine controllers are under the supervision of the main wind turbine control computer located at the SCI PWC diesel power plant.

Electrical: The MICON wind turbine is equipped with phase compensation which improves the power factor to 0.96 lagging. Over-voltage protection in case of lighting is provided in the control system. Soft cut-in is also provided by thyristors that limit the in-rush current to 1.3 times normal current. 


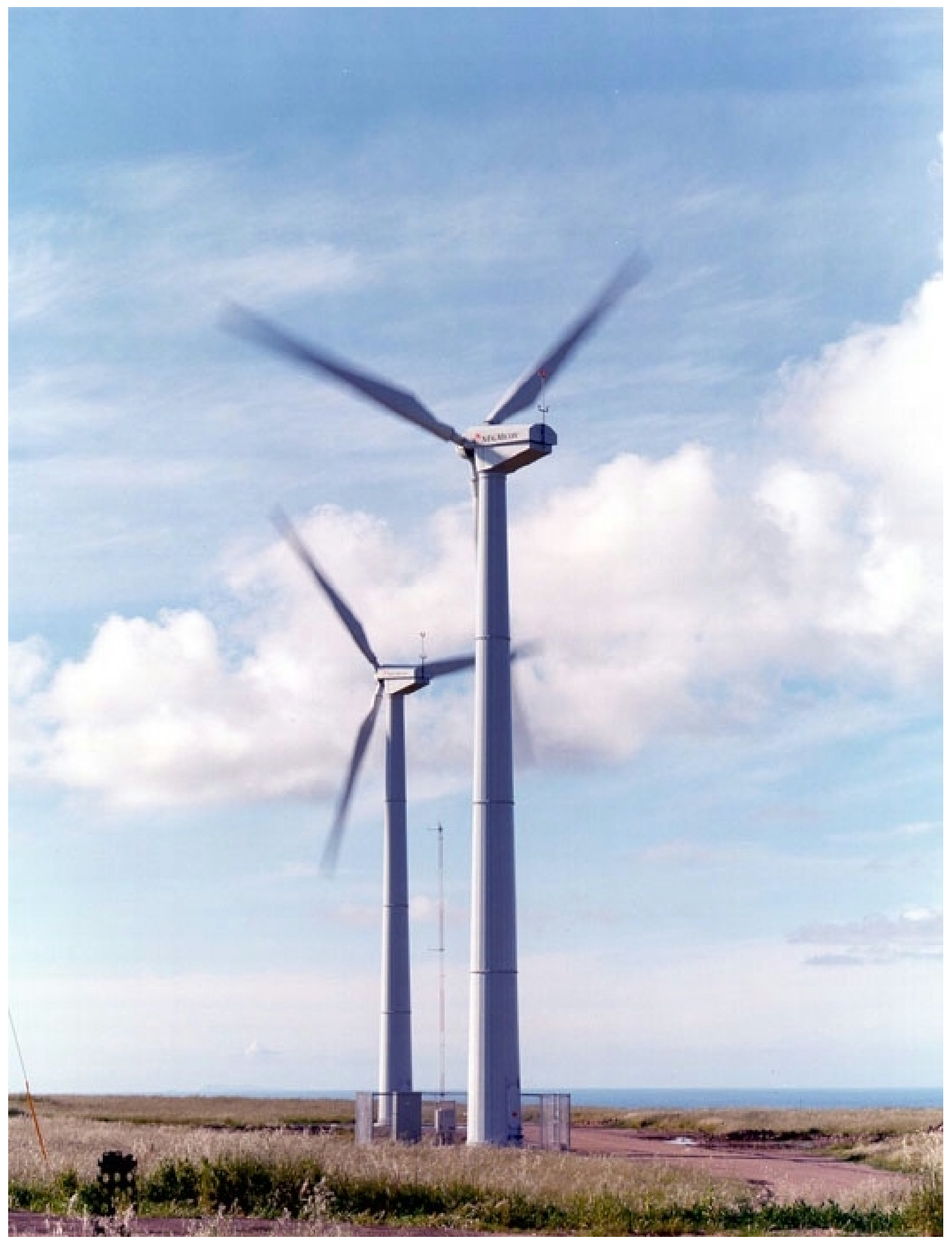

Figure 10: SCI SERDP-Funded NM 225-30 (225 kW) Wind Turbines Source: USN NFESC Photograph 


\subsection{THE WIND RESOURCE}

\subsection{Wind Data Collection and Analysis}

In July 1994, the National Renewable Energy Laboratory (NREL) entered into a cooperative agreement with the Naval Facilities Engineering Service Center (NFESC) to collect one full year of high quality wind energy resource data at San Clemente Island (SCI) old Jacobs wind turbine facility, (Tower \#6) at 18.3-m (60-ft) height. Three additional UNR-ROHN 43-m (140-ft) towers were installed by NREL crews at SCI sites Met2: $32^{\circ} 59.236 \mathrm{~N}$ by $118^{\circ} 33.209 \mathrm{~W}$ (at the present $450 \mathrm{~kW}$ wind turbine site), Met3: $32^{\circ} 58.630 \mathrm{~N}$ by $118^{\circ} 33.977 \mathrm{~W}$ (approximately 1 mile south of Met2), and Met4: $33^{\circ} 01.248 \mathrm{~N}$ by $118^{\circ} 33.041 \mathrm{~W}$ (Lemon Tank Reservoir). We examined the Met2 data in detail, and reviewed historical summary data to describe long-term wind characteristics.

The new data were collected through a full wind-energy meteorological sensor system including two anemometers, two wind vanes, a temperature probe, and a barometric pressure sensor. The anemometers were mounted $24.4-\mathrm{m}(80-\mathrm{ft})$ and $42.7-\mathrm{m}(140-\mathrm{ft})$ high at the new wind energy site on tower Met2.

Data collection began in August 1995, and continued through January 1999. All data was sampled at $1 \mathrm{~Hz}$ and then stored as 10-minute and 24-hour averages. The 10-minute average data was used for this report. Annual records of the 10-minute average wind speed, and the monthly records use daily averages. An annual record is derived for air density using

$$
\rho=p /\left(R^{*} T\right)
$$

where $\rho$ is density, $\mathrm{p}$ is pressure, $\mathrm{T}$ is temperature, and $\mathrm{R}=0.286 \mathrm{~kJ} /(\mathrm{kg} * \mathrm{~K})$ for air. Then wind power density is derived using

$$
\mathrm{P} / \mathrm{A}=0.5 * \rho * \mathrm{~V}^{3}
$$

where $\mathrm{P}$ is power, $\mathrm{A}$ is area, and $\mathrm{V}$ is wind speed. Using hourly average data, the diurnal wind speeds are created by computing an average for each hour of the day over all days in the period.

Wind direction data is difficult to present because the most common directions do not necessarily have the strongest winds. Therefore, this report includes three types of wind roses: percent time at each direction, average wind speed at each direction, and time-weighted average wind speed at each direction.

\subsection{Historical Wind Data}

This section begins with a review of 19 years of wind-speed data (1960-1978) at SCI station number 93117, compiled by Pacific Northwest Laboratories and archived by the National Climatic Data Center [2]. Historical annual average wind speeds follow in Figure 11. 
The airfield began its operations in 1960 and the historical 19-year anemometer locations changed several times for this collection of historical wind data, and used different sensors, mountings, heights, exposures, and possibly drifting calibrations. Readings on the historical data were made 24 times a day after the first 3-years, which were read 5 to 11 times a day. The heights varied from $5.2 \mathrm{~m}$ to $7.9 \mathrm{~m}$, so each year's data were adjusted to the wind turbine hub height [30.0 m (98.4 ft)] using the $1 / 7$ power law. These low measurement heights are very susceptible to the effects of obstructions.

The average 19-year wind speed at SCI adjusted to the $30.0 \mathrm{~m}(98.4 \mathrm{ft})$ height is $4.0 \mathrm{~m} / \mathrm{s}(7.8$ knots) based on annual averages of hourly data, and the average of the annual standard deviations is $2.6 \mathrm{~m} / \mathrm{s}$ (5.1 knots). The standard deviation of the annual averages is $0.7 \mathrm{~m} / \mathrm{s}(1.3 \mathrm{knots})$, giving a variability of $0.7 / 4.0=0.175$, or $17.5 \%$. Although confidence in the average wind speed is low, this variability implies that the annual average wind speed will fall within $+/-53 \%$ (3 standard deviations) $99 \%$ of the time, assuming these values are normally distributed.

Some bias toward lower wind speed measurements is expected because of low heights, proximity to buildings and other obstructions, and possible binding (bearing or shaft roughness) of older anemometers. The airfield's altitude is $55.5 \mathrm{~m}$ (182ft). The ASR-8 Radar hill with an east-west ridge peaking at $160 \mathrm{~m}(524 \mathrm{ft})$ south of the airfield is approximately $2,300 \mathrm{~m}(7,500 \mathrm{ft})$ away. Although the ridge does not shadow the prevailing north to northwest winds, it can deflect them upward and cause lower measurements below. Winds from the northeast to southwest are sheltered. Because these factors are not tractable, no attempt is made to adjust the data to account for them. However, the averages found here are not used for the hybrid system modeling later in this report, but the interannual variability of $17.5 \%$ is used for the sensitivity analysis.

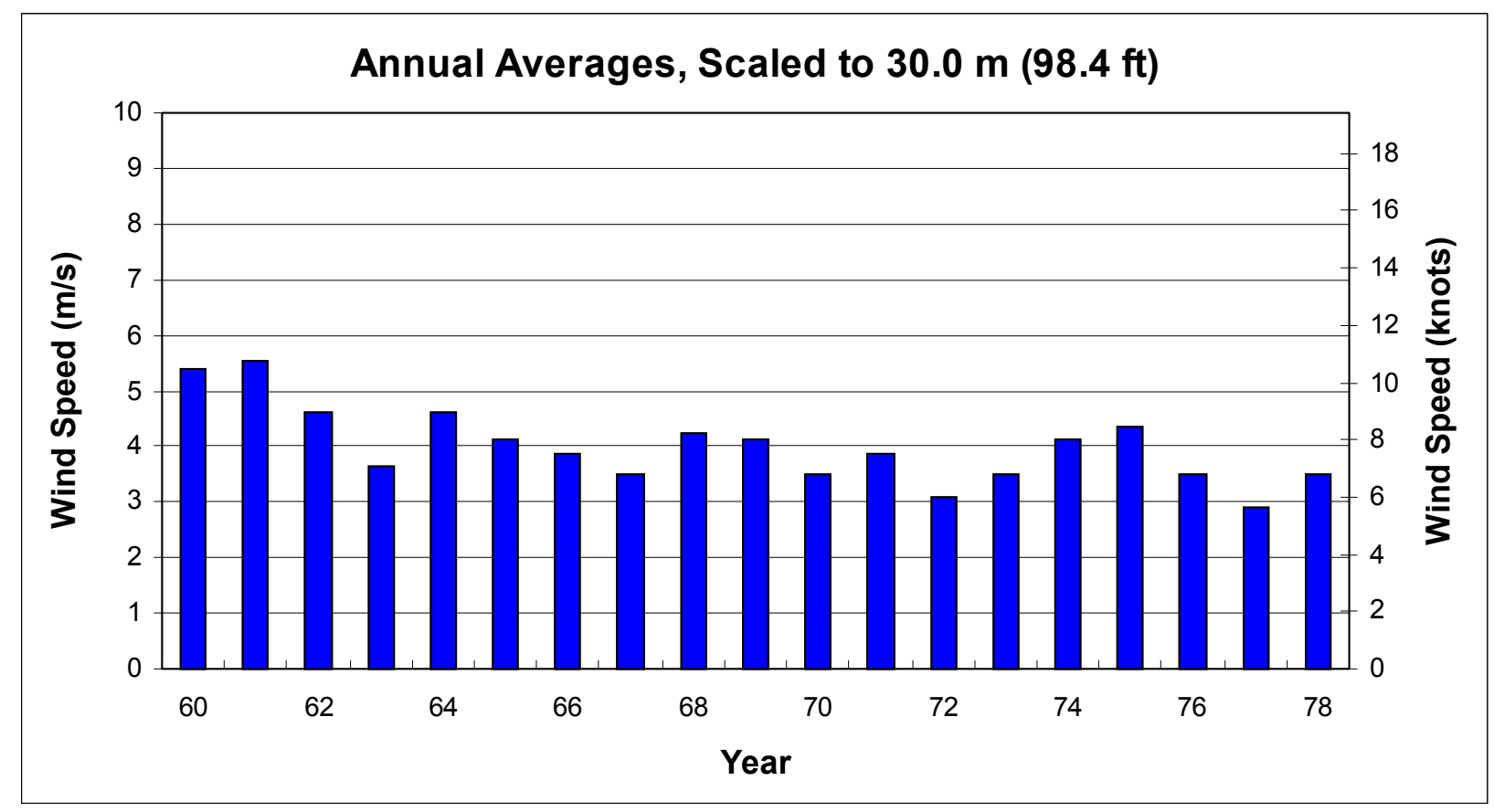

Figure 11: SCI Historical Wind Speeds 
The following figures, 12 and 13, show some average diurnals from 1983-4 and 1984-5 collected at the old Jacobs site [3]. The data was collected with a MAXIM type 40 anemometer at $32 \mathrm{ft}$ elevation and a Second Wind Datalogger Model A1-2002-4K. The average wind speed for both

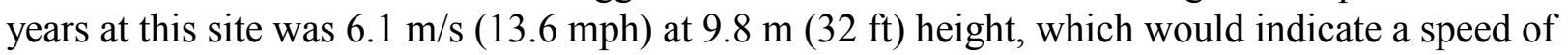
$7.2 \mathrm{~m} / \mathrm{s}(16.0 \mathrm{mph})$ at $30.5 \mathrm{~m}(100 \mathrm{ft})$ using the $1 / 7$ power law.

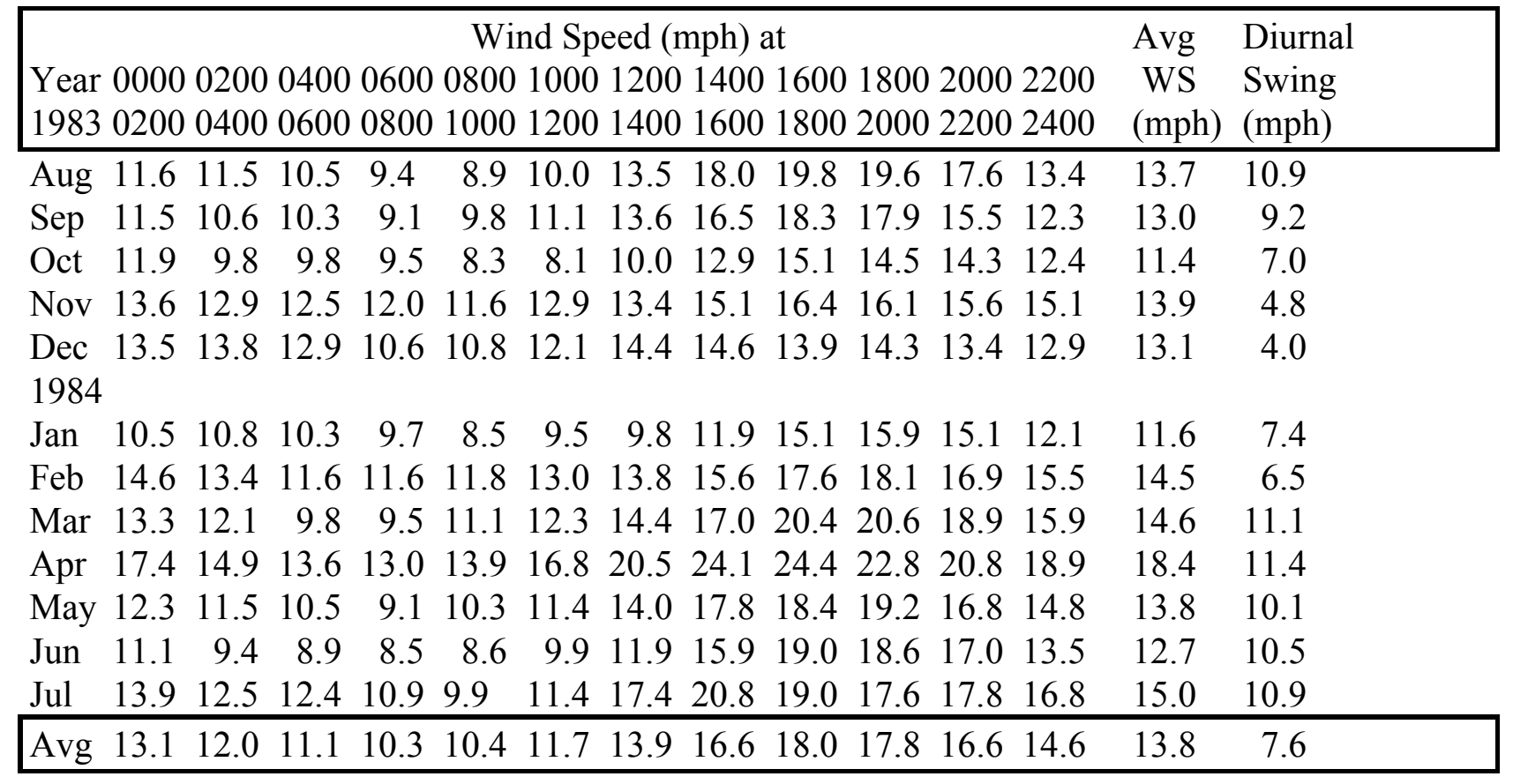

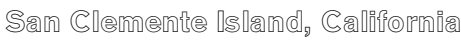

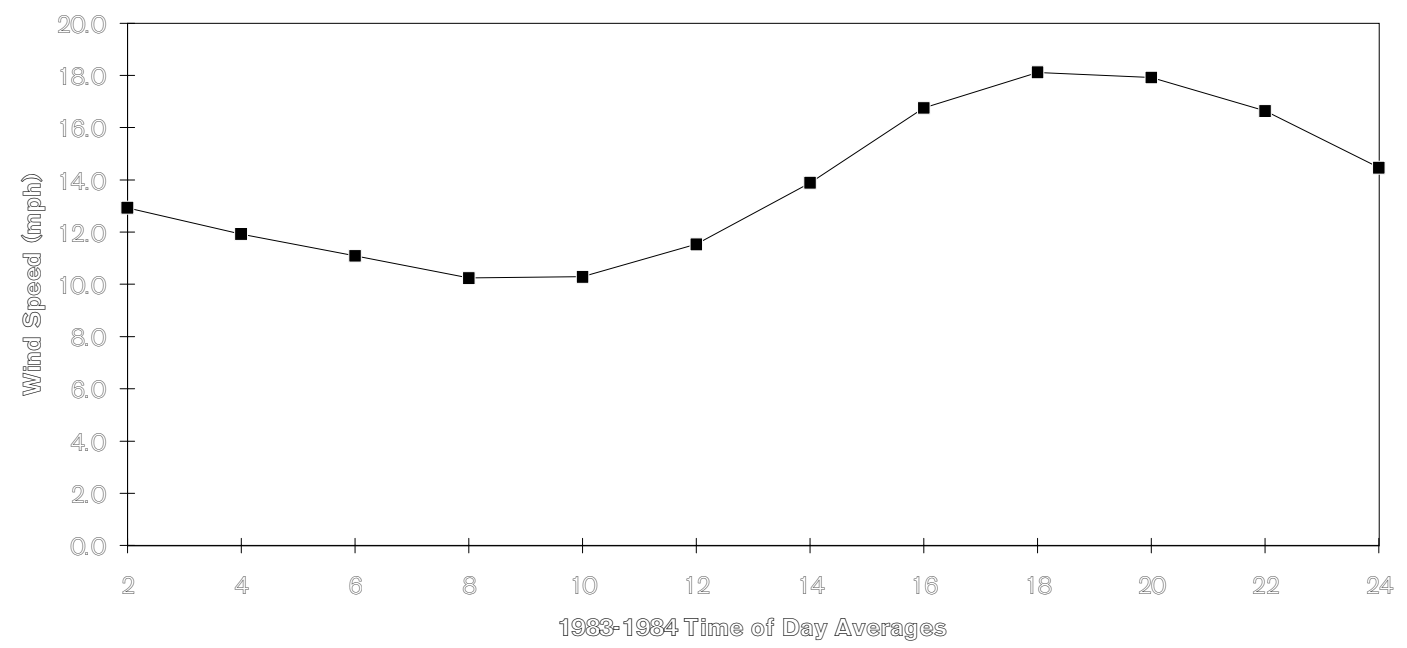

Figure 12: Annual Average Diurnal, Jacobs Site, 1983-4 


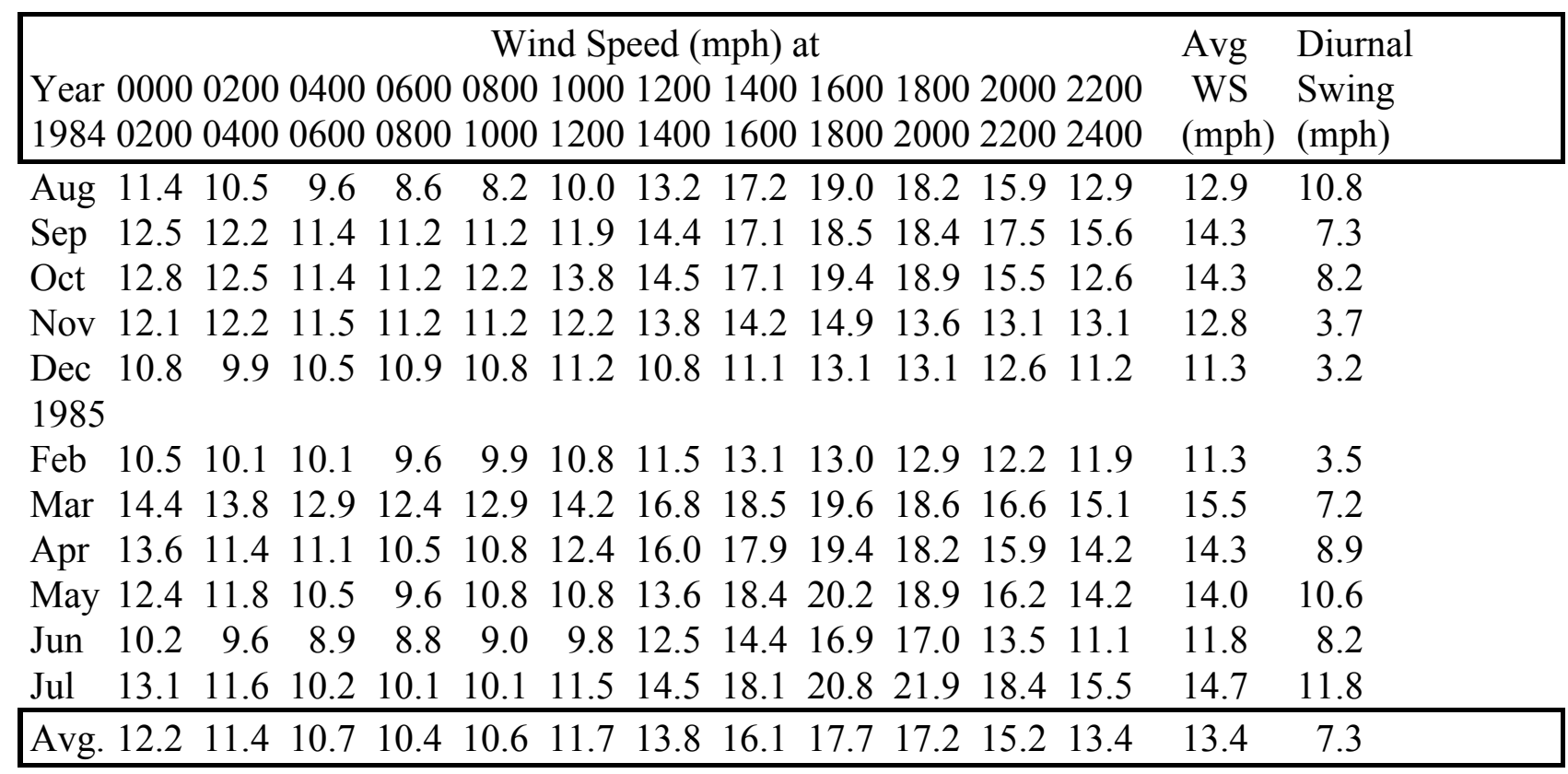

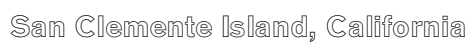

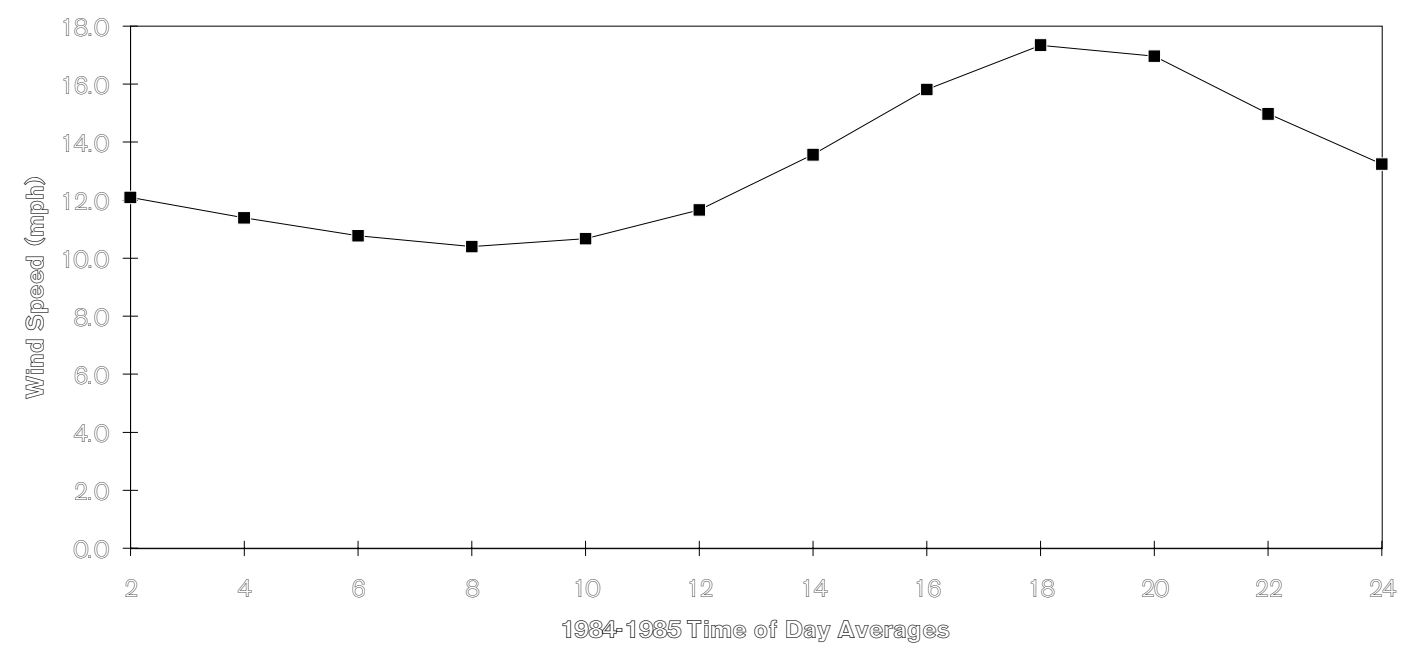

Figure 13: Annual Average Diurnal, Jacobs Site, 1984-5 


\subsection{Current Wind Data}

Data were collected between August 1995 and January 1999 at the 43.6-m (140-ft) meteorological tower number 2 at the designated SCI Wind Turbine Site. The wind speed data was collected at 43.6-m (140-ft) height and temperature and pressure at 3-m (10-ft).

The data collection rate was about $75 \%$, with several gaps spread throughout the data sets. This low collection rate is attributed to a lack of available staff for checking, downloading data, and maintaining the site data acquisition systems. In addition, the data shows error rates of 5 to $10 \%$. Because no year has a full data set, a composite 10-minute data set was created to use for generating a wind speed histogram, annual diurnal, wind rose, and hourly data for hybrid system modeling. Using 1998 as the baseline data set, both missing data and bad data segments were filled in with good data segments from the other years as itemized in Table 3.

\section{Table 3: Source Years for Composite Wind Data Set}

$\begin{array}{cc}\begin{array}{c}\text { Julian } \\ \text { Day }\end{array} & \begin{array}{c}\text { Source } \\ \text { Year }\end{array} \\ 1-31 & 1999 \\ 32-36 & 1996 \\ 37-238 & 1998 \\ 239-273 & 1995 \\ 274-284 & 1998 \\ 285-287 & 1995 \\ 288-365 & 1998\end{array}$

Statistical analysis of the last 3-years of daily meteorological data yielded the results shown in Table 4, and a full wind speed distribution is presented in Figure 14. Subsequent hybrid system modeling used the composite data set adjusted to wind turbine hub height. The 10-minute data set was not used here because of the amount of manual processing required to remove bad data segments. However, the 10-minute data would indicate somewhat higher standard deviations of $3.3 \mathrm{~m} / \mathrm{s}$ and lower minima of $0.0 \mathrm{~m} / \mathrm{s}$ (both affected by bad data), with maxima reaching $25.9 \mathrm{~m} / \mathrm{s}$.

Table 4: Summary of Current SCI Meteorological Data

\begin{tabular}{lccccc} 
Channel & Units & Average & $\begin{array}{c}\text { Standard } \\
\text { Deviation }\end{array}$ & Minimum & Maximum \\
\hline Wind Speed, 1996 & $\mathrm{m} / \mathrm{s}$ & 6.1 & 2.7 & 1.8 & 16.9 \\
Wind Speed, 1997 & $\mathrm{m} / \mathrm{s}$ & 5.5 & 2.6 & 1.4 & 18.0 \\
Wind Speed, 1998 & $\mathrm{m} / \mathrm{s}$ & 6.6 & 2.7 & 2.3 & 17.0 \\
Wind Speed, composite & $\mathrm{m} / \mathrm{s}$ & 6.4 & 2.7 & 2.3 & 17.0 \\
Wind Speed, composite & $\mathrm{knots}$ & 12.4 & 5.2 & 4.5 & 33.0 \\
Ambient Temp, 1998 & ${ }^{\circ} \mathrm{C}$ & 14.4 & 2.5 & 8.2 & 22.8 \\
Ambient Pressure, 1998 & $\mathrm{mbar}$ & 990 & 3.3 & 981 & 1002 \\
Air Density, 1998 & $\mathrm{kg} / \mathrm{m}^{3}$ & 1.20 & 0.01 & 1.17 & 1.24 \\
Power Density, 1998 & $\mathrm{W} / \mathrm{m}^{2}$ & 267 & 400 & 7.6 & 2990
\end{tabular}




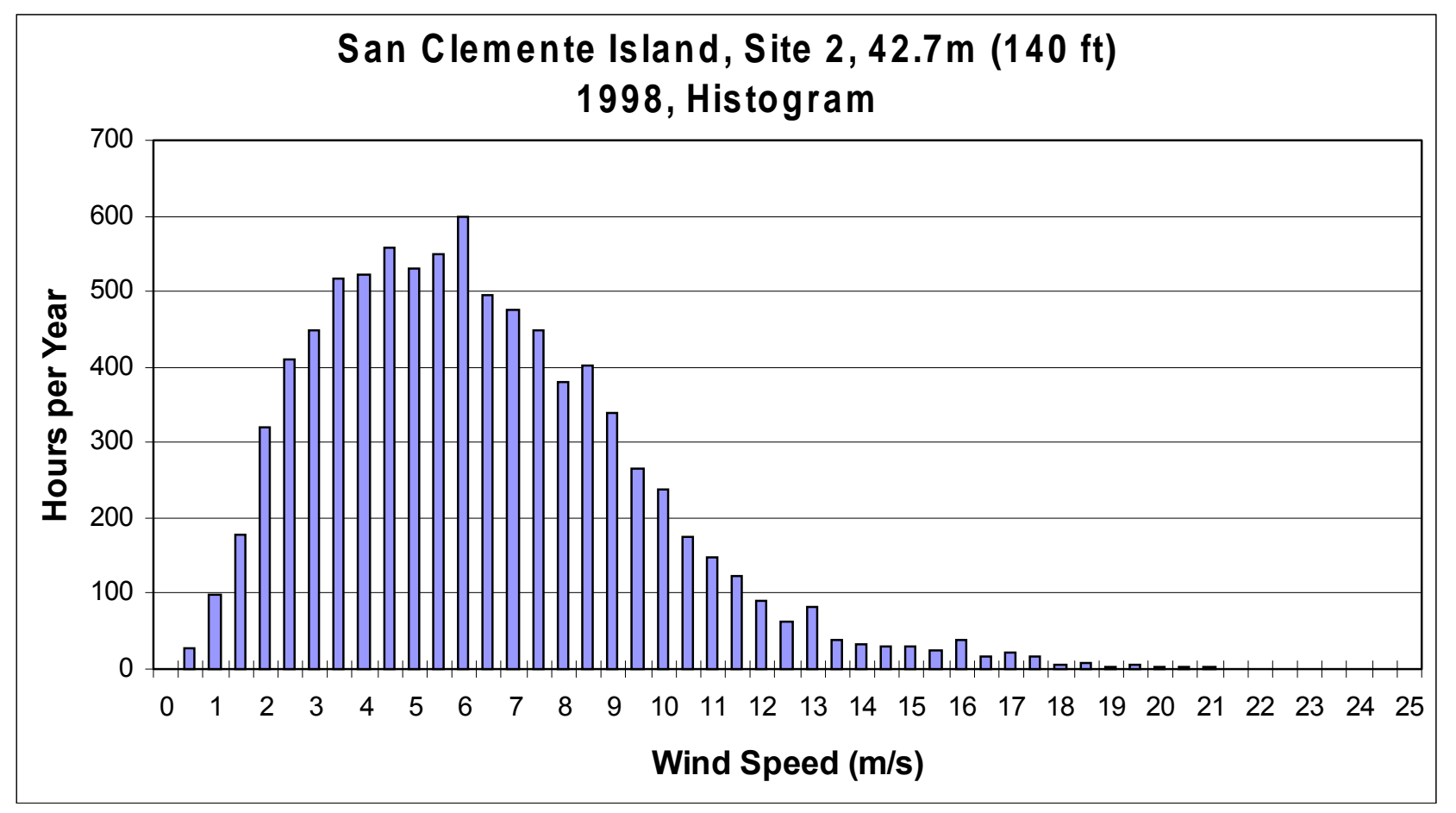

Figure 14: SCI Wind Speed Frequency Distribution

Annual records using monthly averages have been plotted for wind speed, ambient temperature, ambient pressure, air density, and power density. The source data were derived from NREL testing on SCI at 42.7-m (140-ft) on tower Met2 for the August 1995 through January 1999 period.

Missing and bad data segments were removed from the daily and monthly-averaged data for these records. Wind-speed records for 1995 through 1999 appear in Figures 15-19, and records for other meteorological parameters in 1998 are shown in Figures 20-23.

Wind speeds are fairly consistent at this site; no months stand out as significantly higher or lower between the 3-years examined. The wind speed range generally falls between 5 and $8 \mathrm{~m} / \mathrm{s}$.

Temperature and pressure cycle gently with more warmth and lower pressure in the summer, causing slightly lower summer densities. Power density looks like an exaggeration of wind speed, as expected from its cubic relationship. 


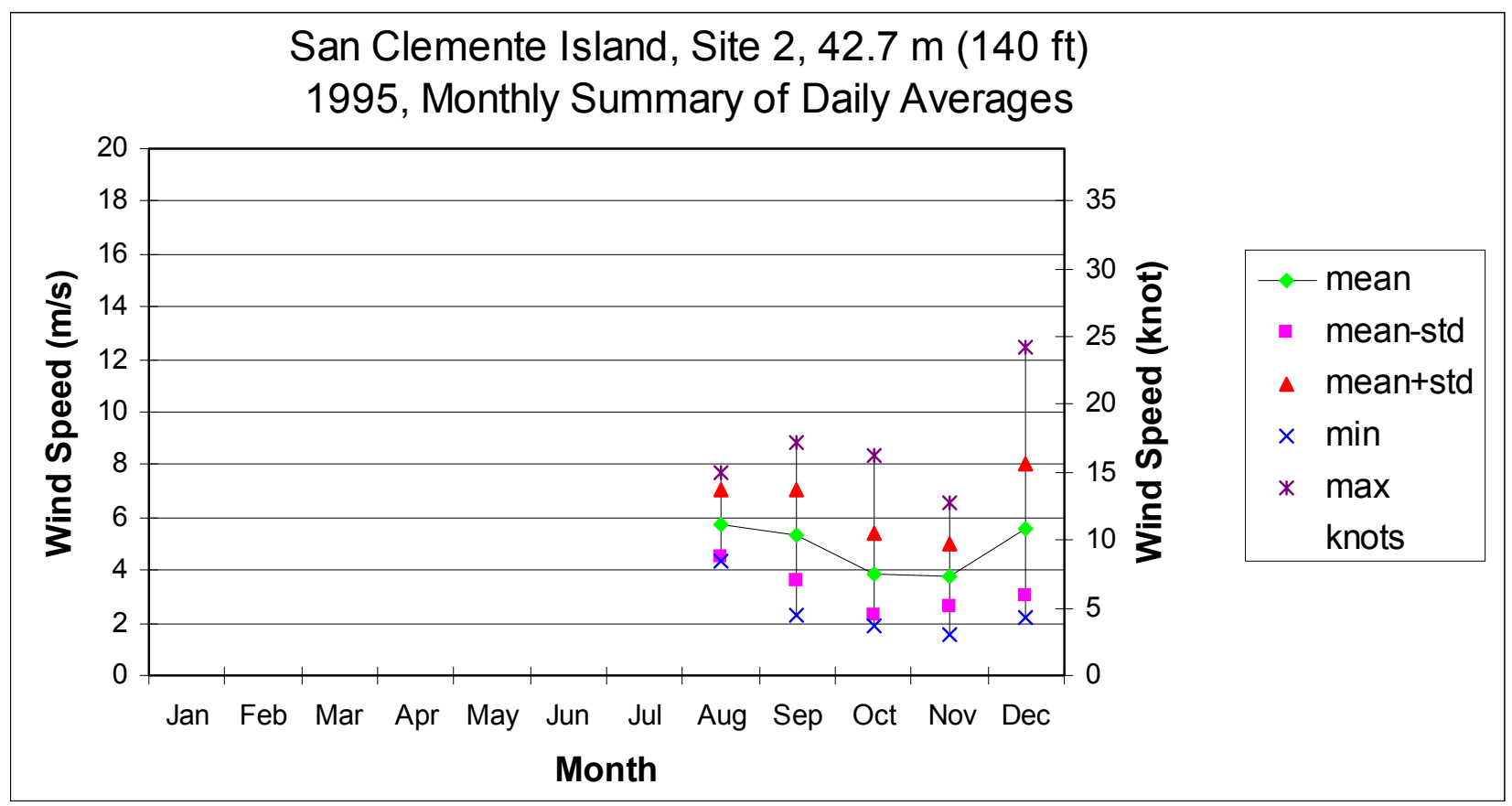

Figure 15: SCI Monthly Averaged Wind Speed, 1995

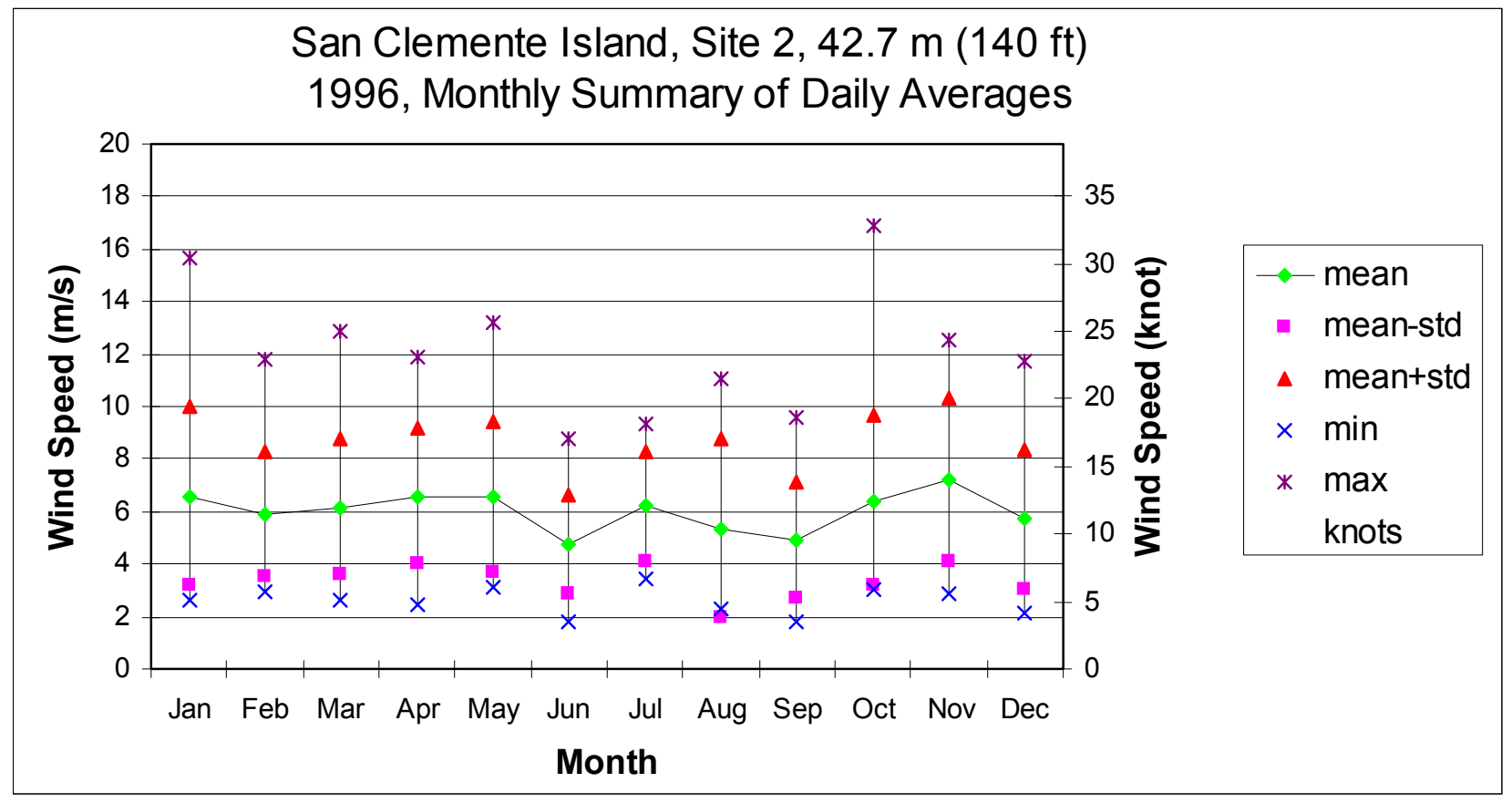

Figure 16: SCI Monthly Averaged Wind Speed, 1996 


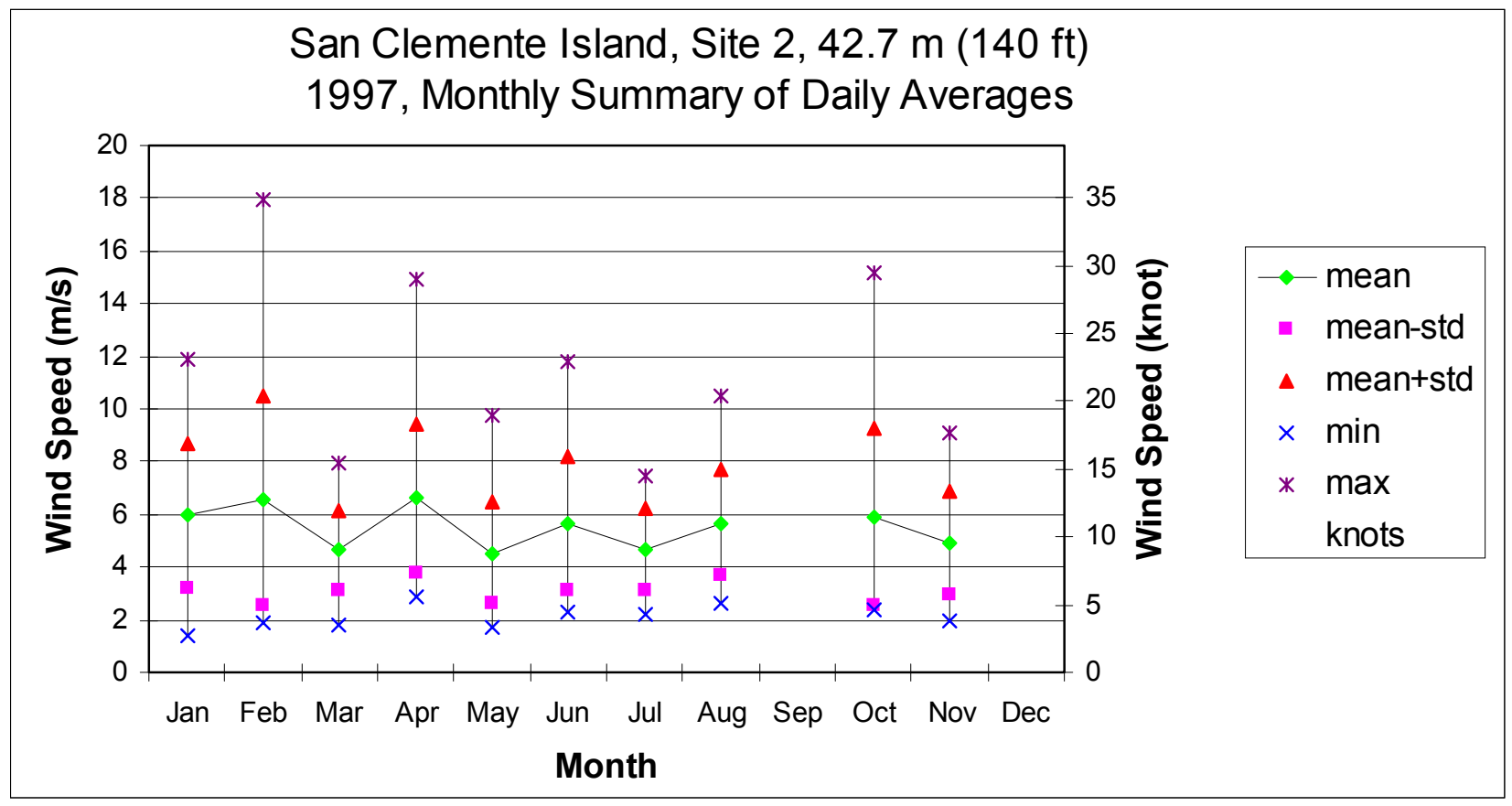

Figure 17: SCI Monthly Averaged Wind Speed, 1997

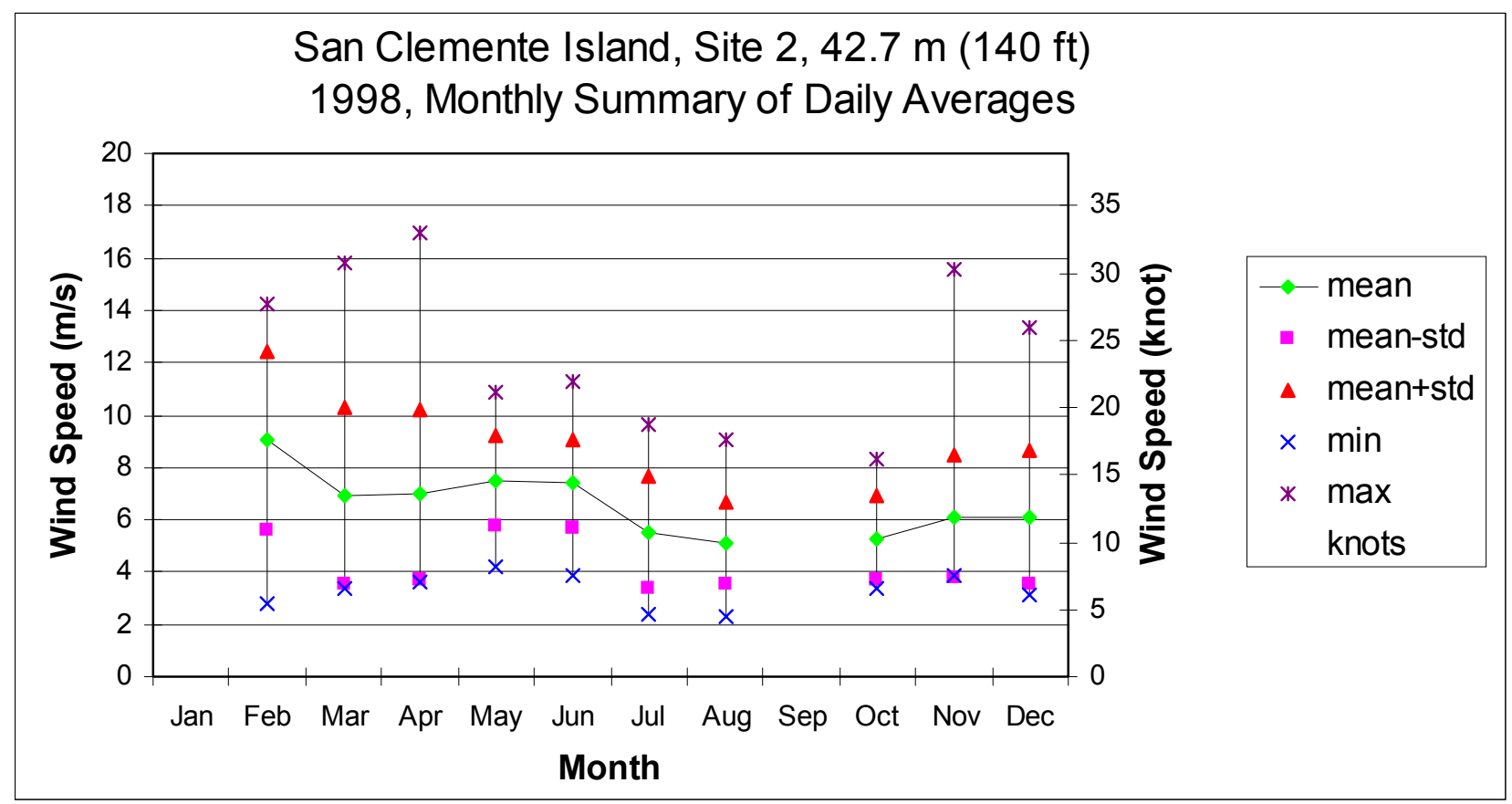

Figure 18: SCI Monthly Averaged Wind Speed, 1998 


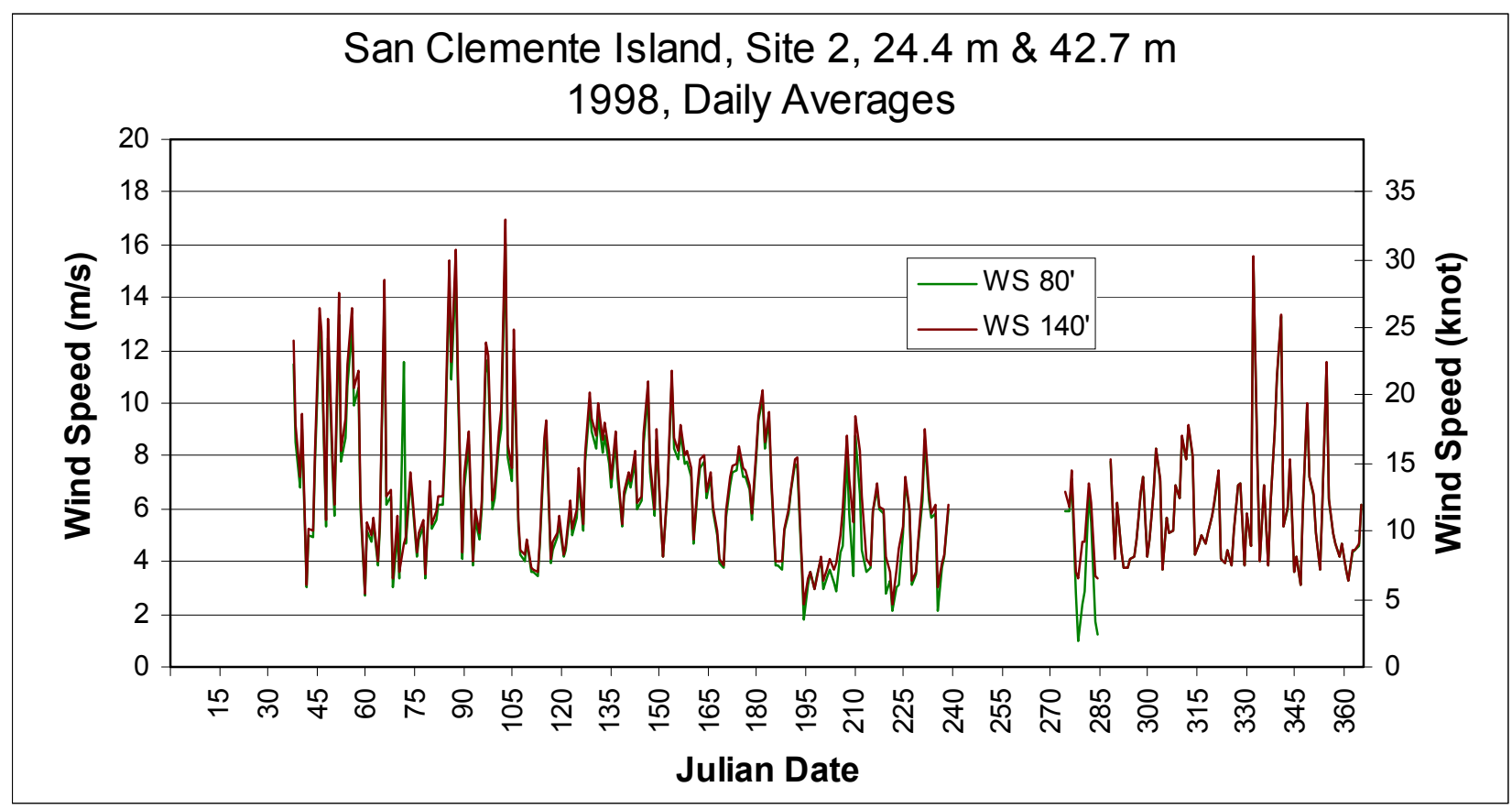

Figure 19: SCI Daily Averaged Wind Speed, 1998

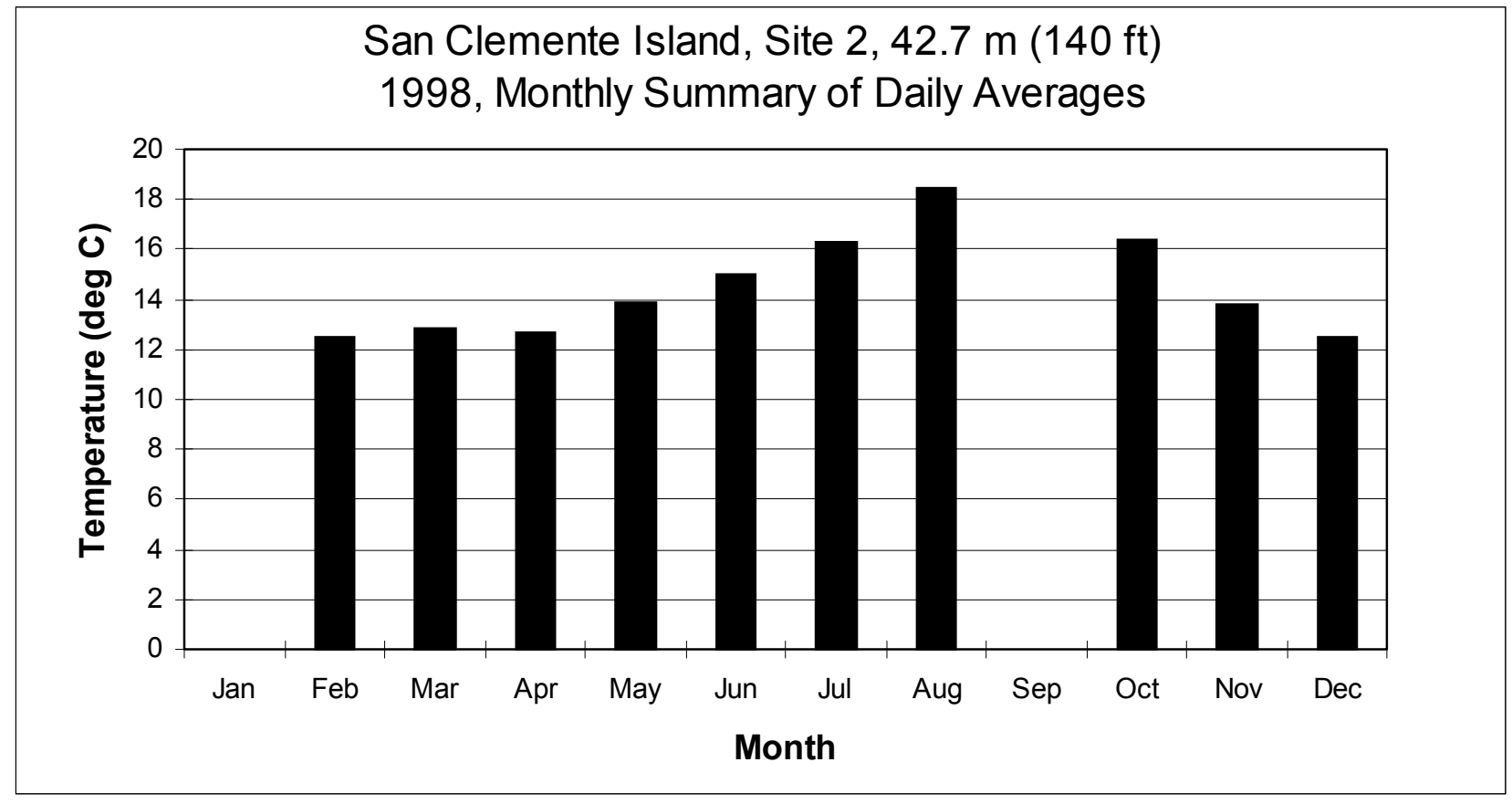

Figure 20: SCI Monthly Averaged Temperature, 1998 


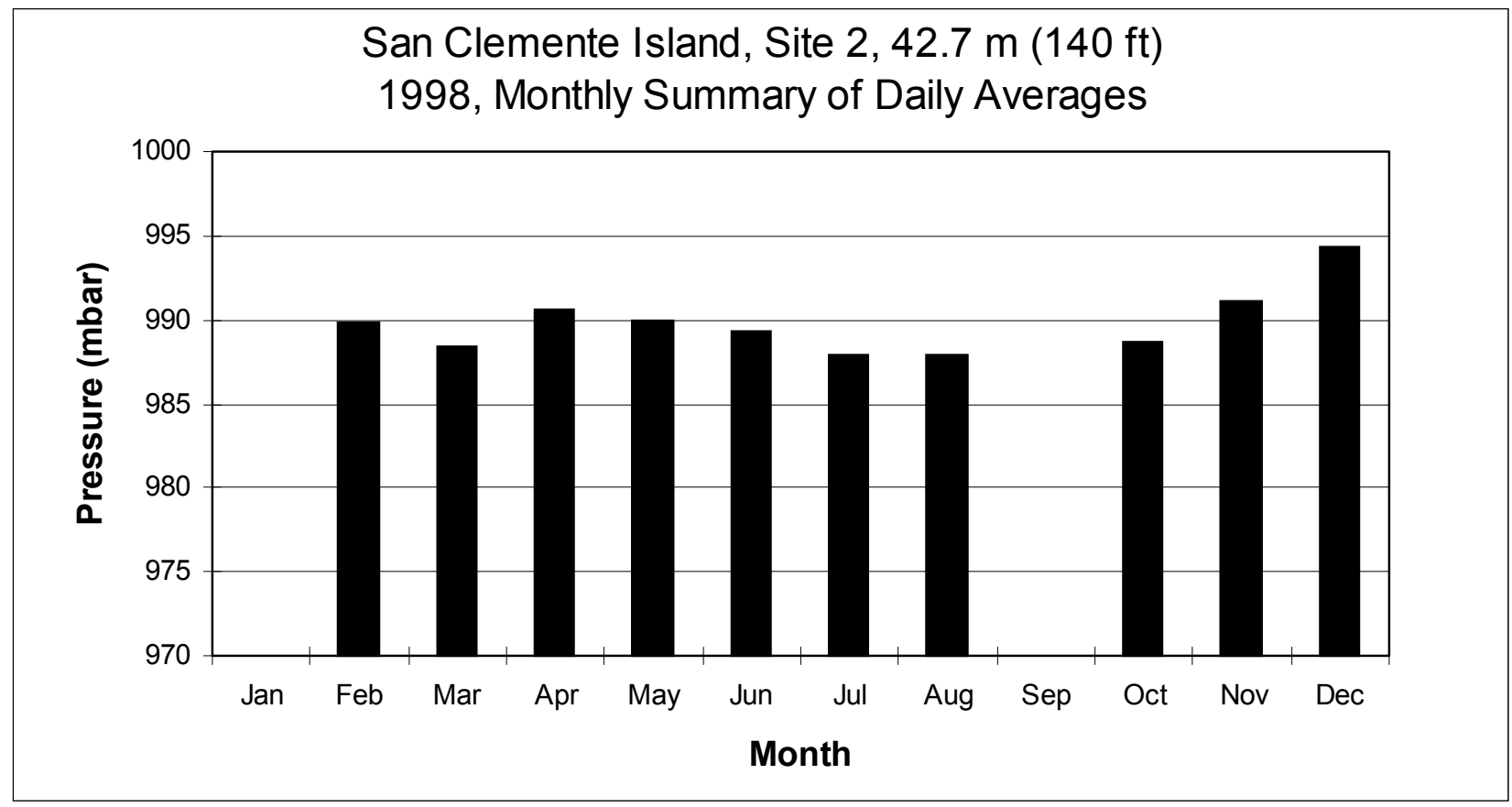

Figure 21: SCI Monthly Averaged Pressure, 1998

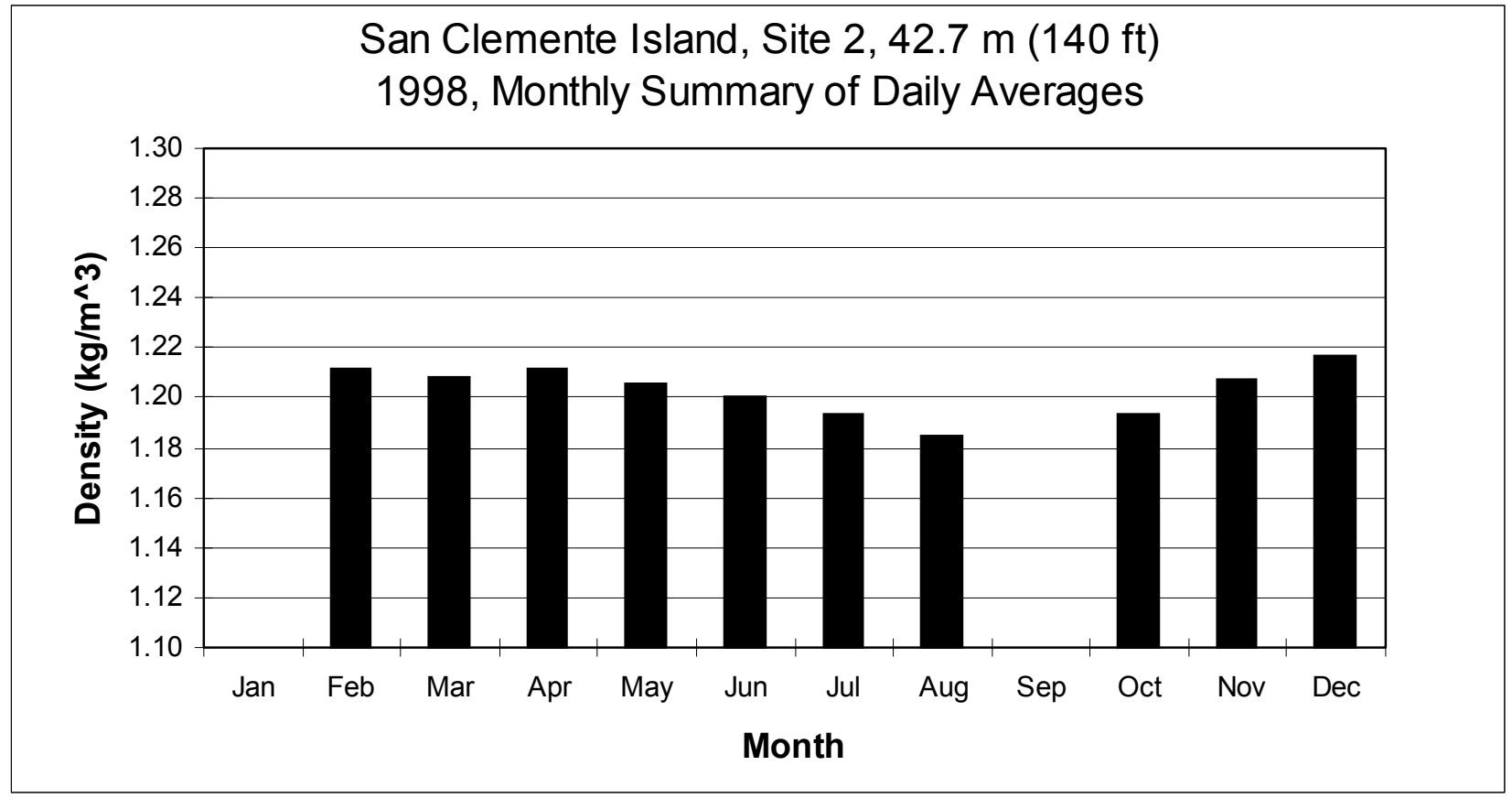

Figure 22: SCI Monthly Averaged Density, 1998 


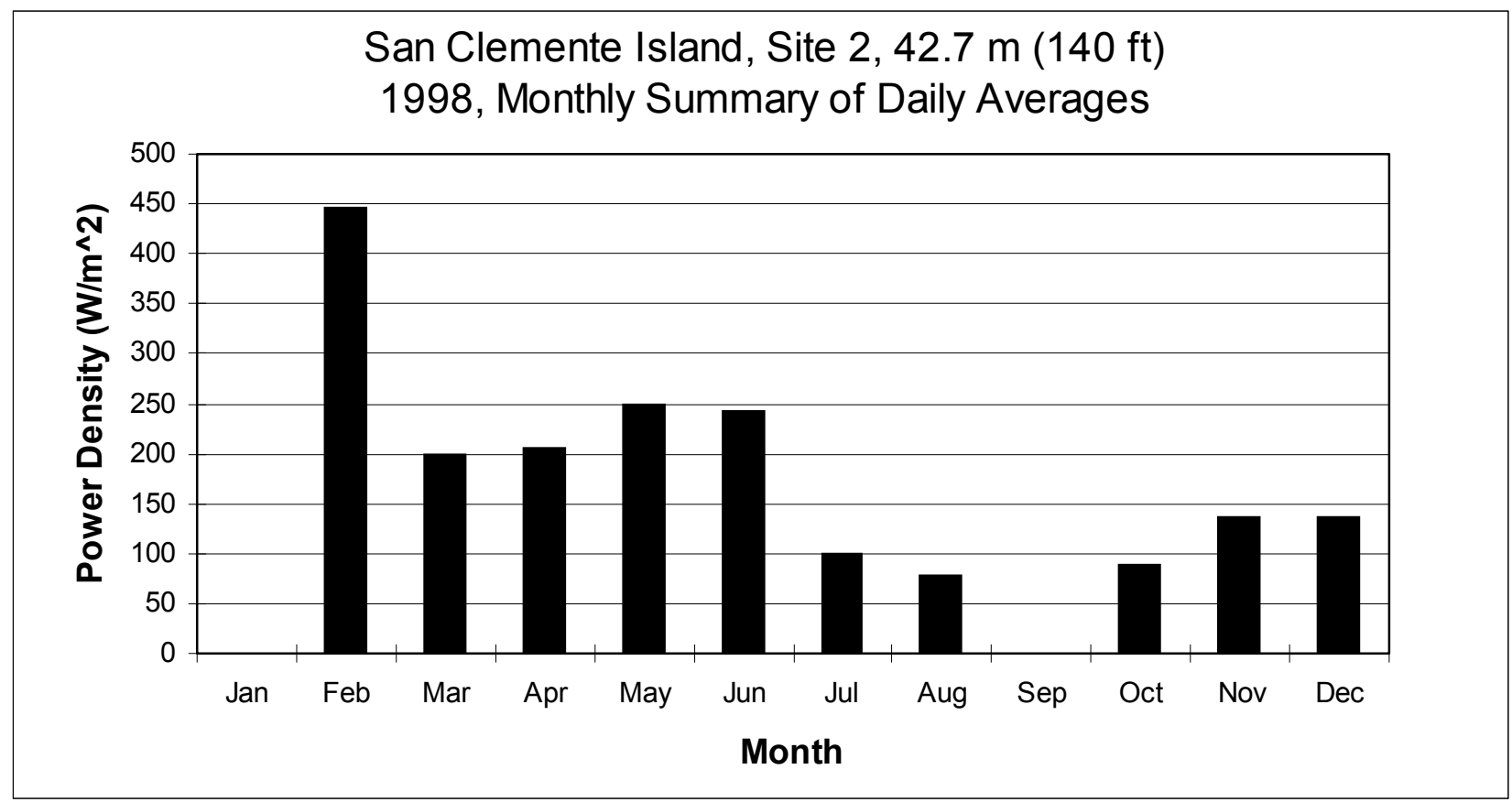

Figure 23: SCI Monthly Averaged Wind Power Density, 1998

The annual average diurnal given in Figure 24 shows a stable pattern, with wind speeds falling between 5 and $7.5 \mathrm{~m} / \mathrm{s}$. They are slightly lower through night and morning, and slightly higher through the afternoon and evening. The diurnal is derived from the 1-year composite hourly data set described earlier. Each hour is averaged through the whole year; any specific day could be quite different. For reference, the column labeled "0000" refers to the first hour of the day: 0000 to 0100 .

The wind roses shown in Figures 25-29 also use the composite hourly data set. They indicate prevailing winds from the west and west by northwest, with somewhat stronger average wind speeds in these directions as well as in the northwest, southwest, and south. 


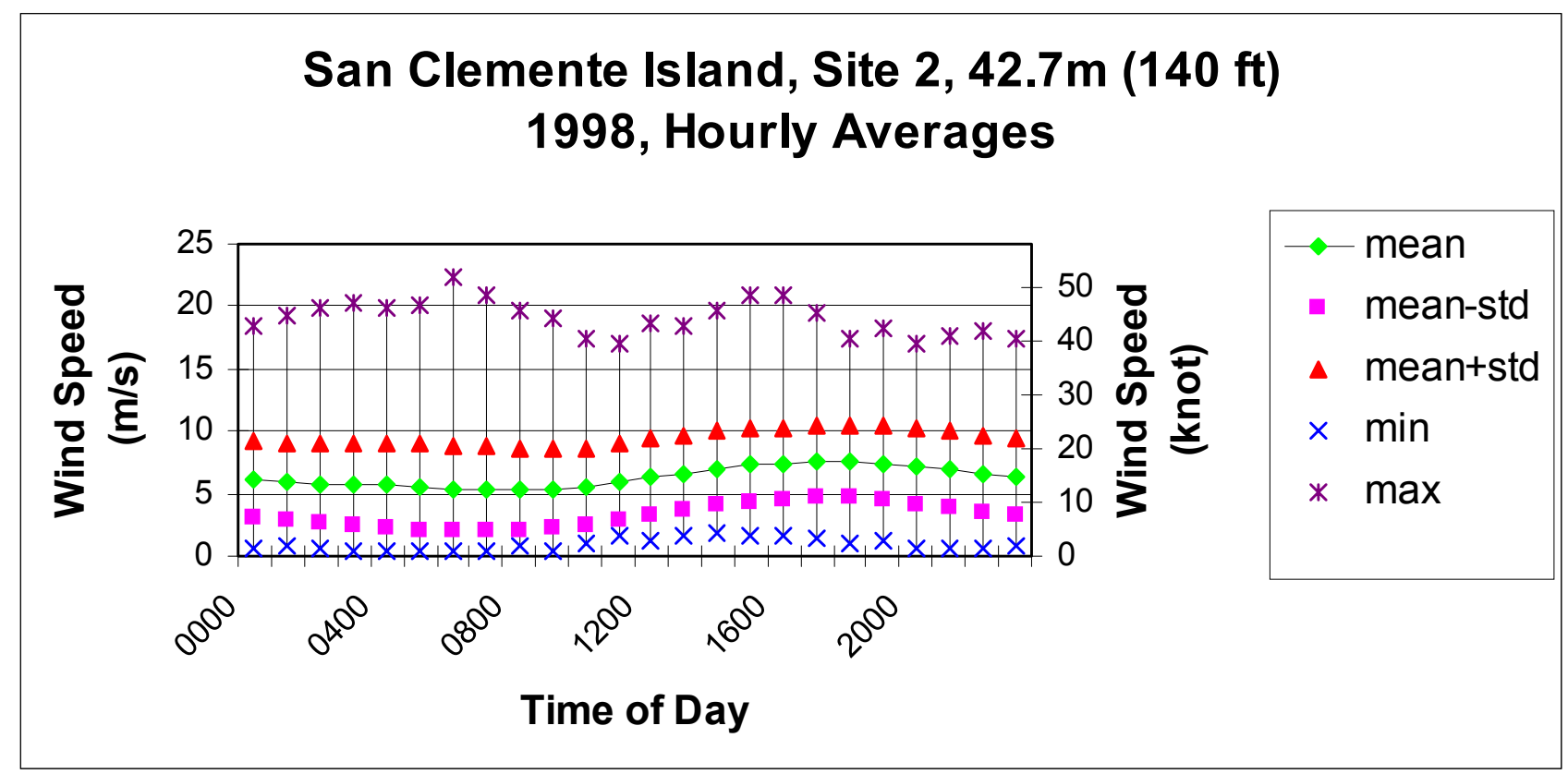

Figure 24: SCI Annual Average Diurnal Wind Speed

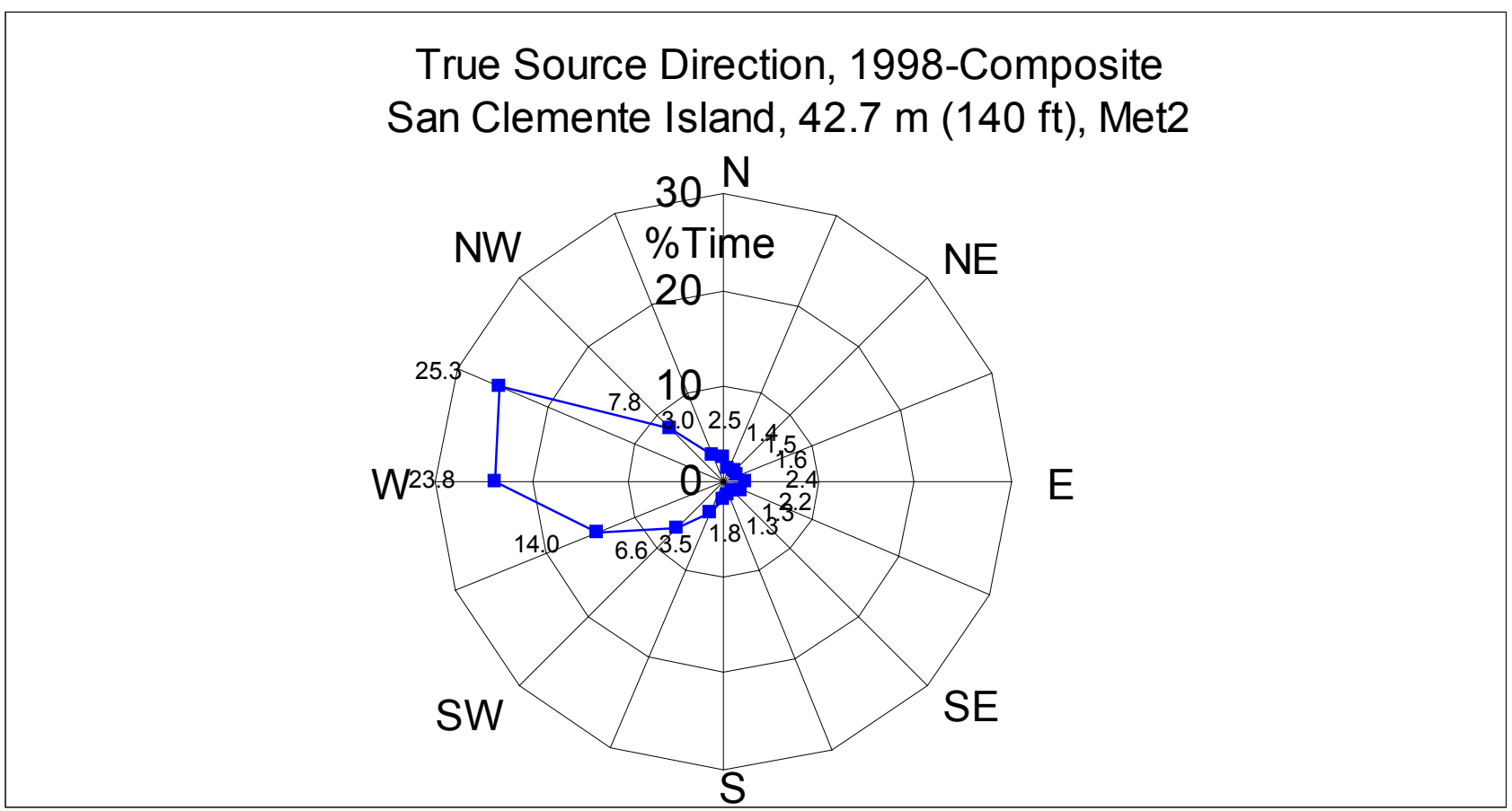

Figure 25: SCI Wind Rose: Percent Time 
True Source Direction, 1998-Composite San Clemente Island, $42.7 \mathrm{~m}$ (140 ft), Met2

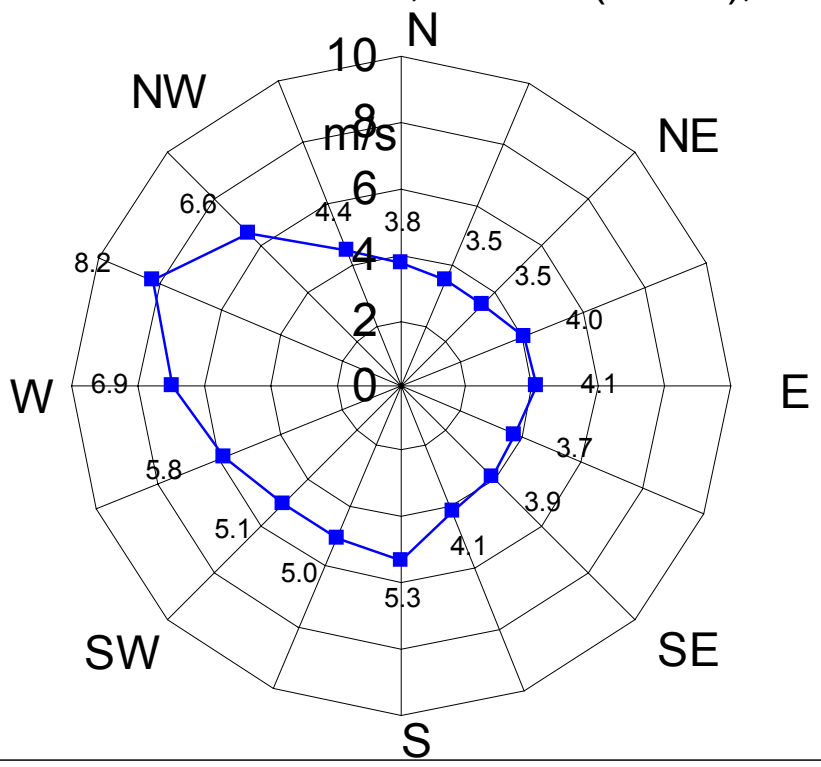

Figure 26: SCI Wind Rose: Average Wind Speed $(\mathrm{m} / \mathrm{s})$

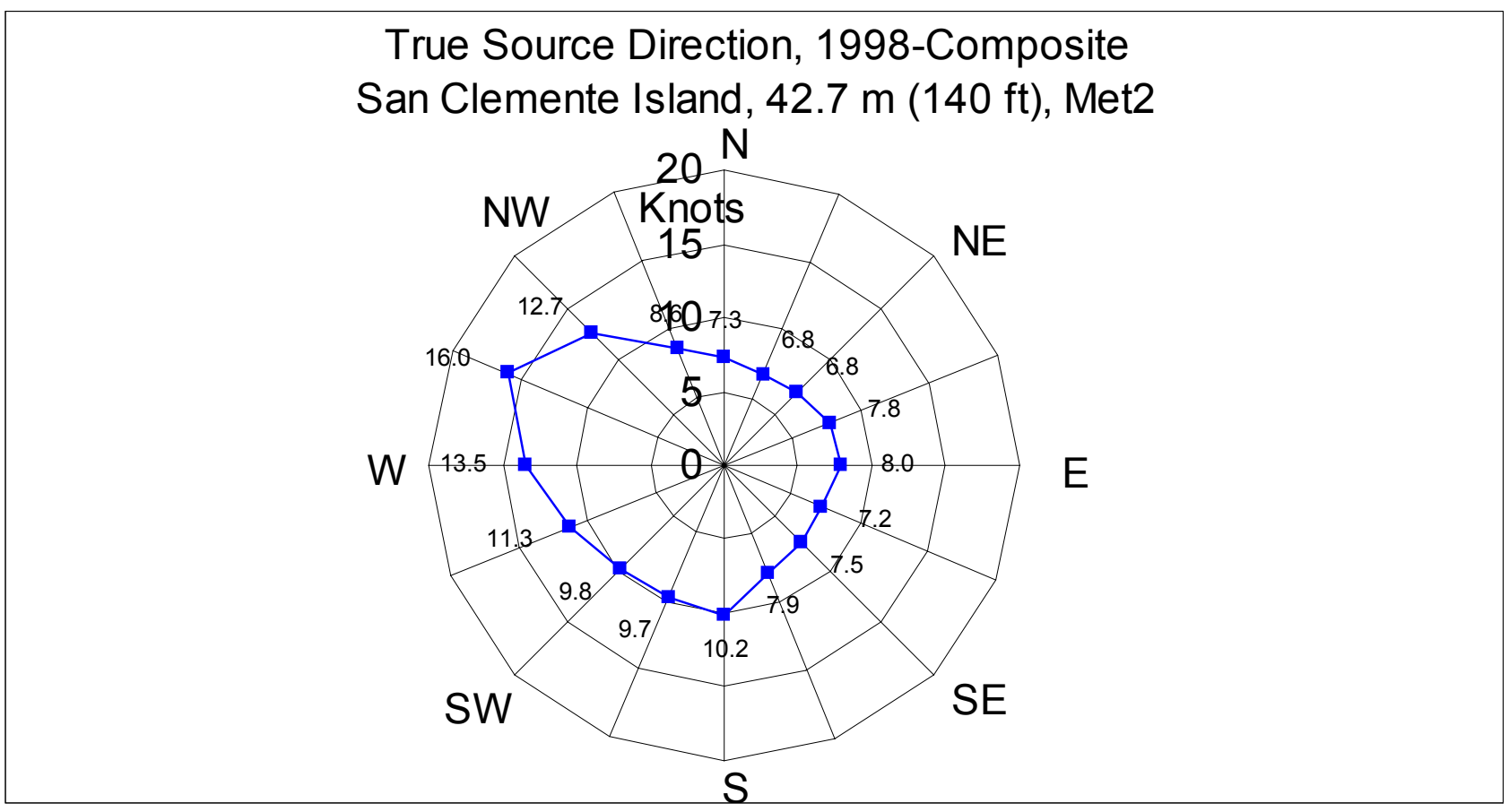

Figure 27: SCI Wind Rose: Average Wind Speed (knots) 
True Source Direction, 1998-Composite

San Clemente Island, $42.7 \mathrm{~m}$ (140 ft), Met2

$\mathrm{N}$

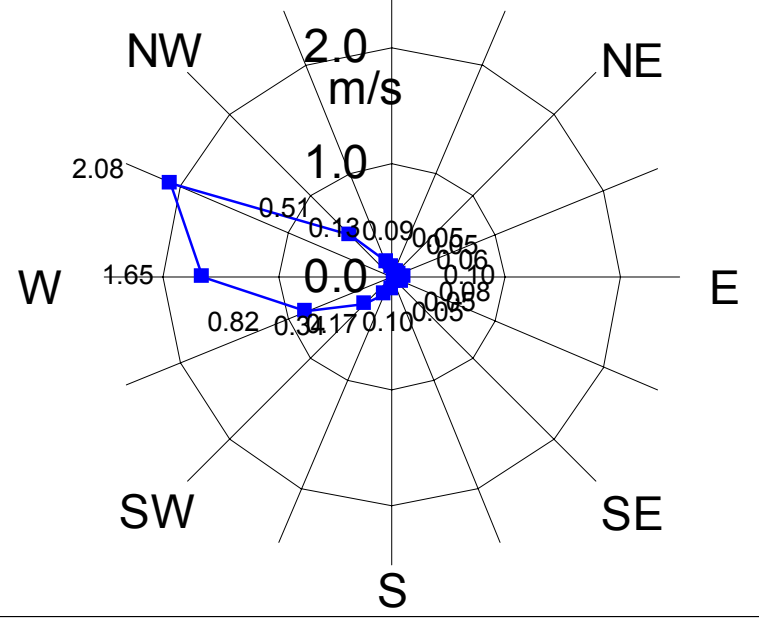

Figure 28: SCI Wind Rose: Time Weighted Average Wind Speed $(\mathrm{m} / \mathrm{s})$

True Source Direction, 1998-Composite

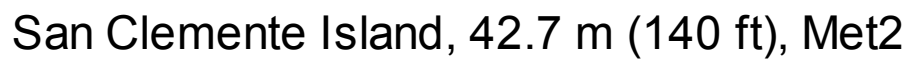

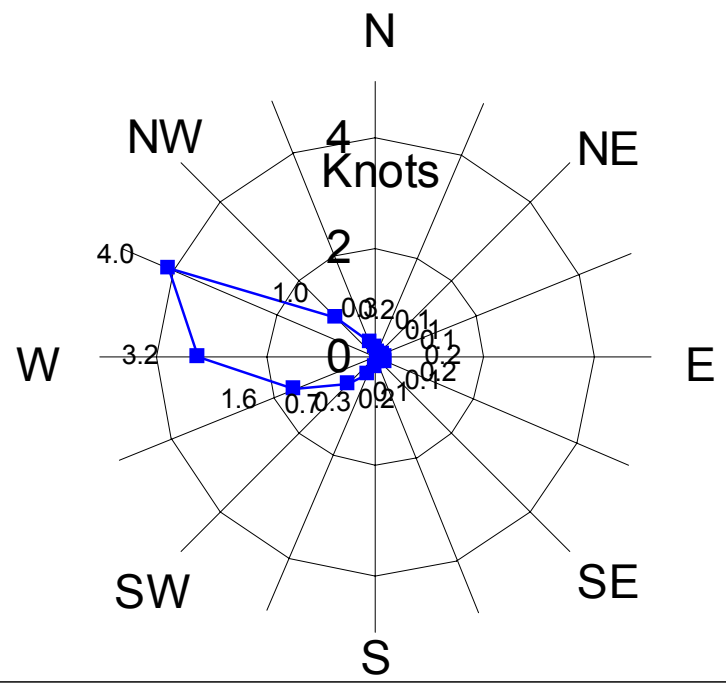

Figure 29: SCI Wind Rose: Time Weighted Average Wind Speed (knots) 


\subsection{WIND-DIESEL HYBRID ENERGY SYSTEM}

The San Clemente Island (SCI) hybrid-energy system, consisting of combined wind and diesel generators is proving to be economically and environmentally advantageous for SCI. A study of such a system was conducted using a spreadsheet program to compare the cost of power generation for the diesel-only baseline to several wind-diesel hybrid cases. The hybrid cases were compared to determine the most cost-effective number of wind turbines.

The wind-diesel hybrid system is relatively simple. Two commercially available wind turbines (total capacity of 450-kW) are combined with the existing 2950-kW diesel generation, a third wind turbine (total wind capacity of $675-\mathrm{kW}$ ) will be online July 1, 1999, and a fourth is scheduled for 2001 (total wind capacity of $900-\mathrm{kW}$ ). With a demand peak of $1350-\mathrm{kW}$, no more than $1700-\mathrm{kW}$ of diesel should be necessary at any time. Therefore, wind penetration of "on-line" capacity with two wind turbines is $450 / 1700=26 \%$, and four wind turbines is $900 / 1700=53 \%$. Based on instantaneous power, wind penetration can range from $0 \%$ when there is no wind to $180 \%$ when peak wind power of $900-\mathrm{kW}$ is combined with a minimum load of $500-\mathrm{kW}$.

Several assumptions were made regarding the power that can be generated by the wind. First, at least $200-\mathrm{kW}$ always must be generated by the existing diesel generators, even if there is excess wind capacity. Second, it is assumed that only the necessary number of turbines will generate power at any given time, with the remaining turbines idled.

\subsection{Diesel System Operation}

As mentioned in Section 2.3, there are four diesel generator sets, two generators rated by the Navy at $500-\mathrm{kW}$, one at $750-\mathrm{kW}$, and one at $1200-\mathrm{kW}$. One generator of each size is included in the hybrid-system model. The generator fuel/energy curves were given in Section 2.3. Typically, only one diesel is run at a time, unless the island's electrical demands require more than $1000-\mathrm{kW}$. Then two diesels are generally on line to provide the electrical capacity required.

The latest SCI power demand for 1998 ranges from a minimum of 500-kW to a maximum of $1350-\mathrm{kW}$. The fuel needed (with no wind-energy input) is calculated based on minimizing the number and rating of operating diesel generators. Configuring the diesels to produce 500, 750, 1200 , or $1700-\mathrm{kW}$ can meet the power demand.

The diesel generators follow the load automatically through speed and frequency monitoring. The diesels have no specific selection priority, but there are other constraints. At least one diesel must be on line at all times to ensure reliable capacity and system stability; the present minimum operating load for the diesels are set at $200 \mathrm{~kW}$, or $40 \%$ rated power for the smallest unit. In the future, this may be set to $100 \mathrm{~kW}$.

Also, according to SCI power system operating data from 1996 to 1998, the manual operating scheme tends to favor running the large engine for long periods of time, as estimated from the Navy-supplied data. That reduces the number of starts. An optimized operating scheme alone 
could provide significant fuel savings, but it would require many more diesel starts and some form of automated system control.

For this study, the spreadsheet model follows the actual manual operating scheme for all cases, wind and baseline. The hybrid wind-diesel systems likely would show greater savings over the baseline with such an optimizer.

\subsection{Wind Turbine Operation}

The wind generation system modeled uses between 1 and 4 commercial wind turbines rated at 225$\mathrm{kW}$ each. The sea level power curve for this turbine is shown in Figure 30. A fifth-order polynomial was fit to the curve for use in the spreadsheet model. No density correction was made to the power curve, as the present San Clemente Island wind site is only $700-\mathrm{ft}$ to $750-\mathrm{ft}$ above sea level. The wind turbines can be curtailed (shut down) as necessary when excess wind energy is available.

The net annual energy production (AEP) can be computed by multiplying the power production level by the number of hours for each wind speed level and summing the results. If $\mathrm{P}_{\mathrm{i}}$ is power and $\mathrm{N}_{\mathrm{i}}$ is number of hours at each wind speed, then:

$$
\operatorname{AEP}=\operatorname{sum}\left(\mathrm{P}_{\mathrm{i}} * \mathrm{~N}_{\mathrm{i}}\right), \quad \mathrm{i}=0.0,0.5,1.0, \ldots 100.0 \mathrm{~m} / \mathrm{s}
$$

The actual AEP is often lower because of various system losses. Assessment of the wind site showed that there are not any significant obstructions to the prevailing wind flow. Also, there is room for additional wind turbines without interference, so array losses should be mitigated with proper siting. Other sources of loss could include $1-5 \%$ availability loss for operation and maintenance, up to $5 \%$ for blade soiling losses, up to $2 \%$ for turbulence losses, and up to $3 \%$ for control, grid, and collection system losses. Using $97 \%$ availability, the combination of these sources is significant, having a possible net loss of $11.5 \%$. However, the first year of operation for the two SCI wind turbines has generated power curves that match the manufacturer's published curve. Therefore, no losses have been applied in the energy system model for this report. 


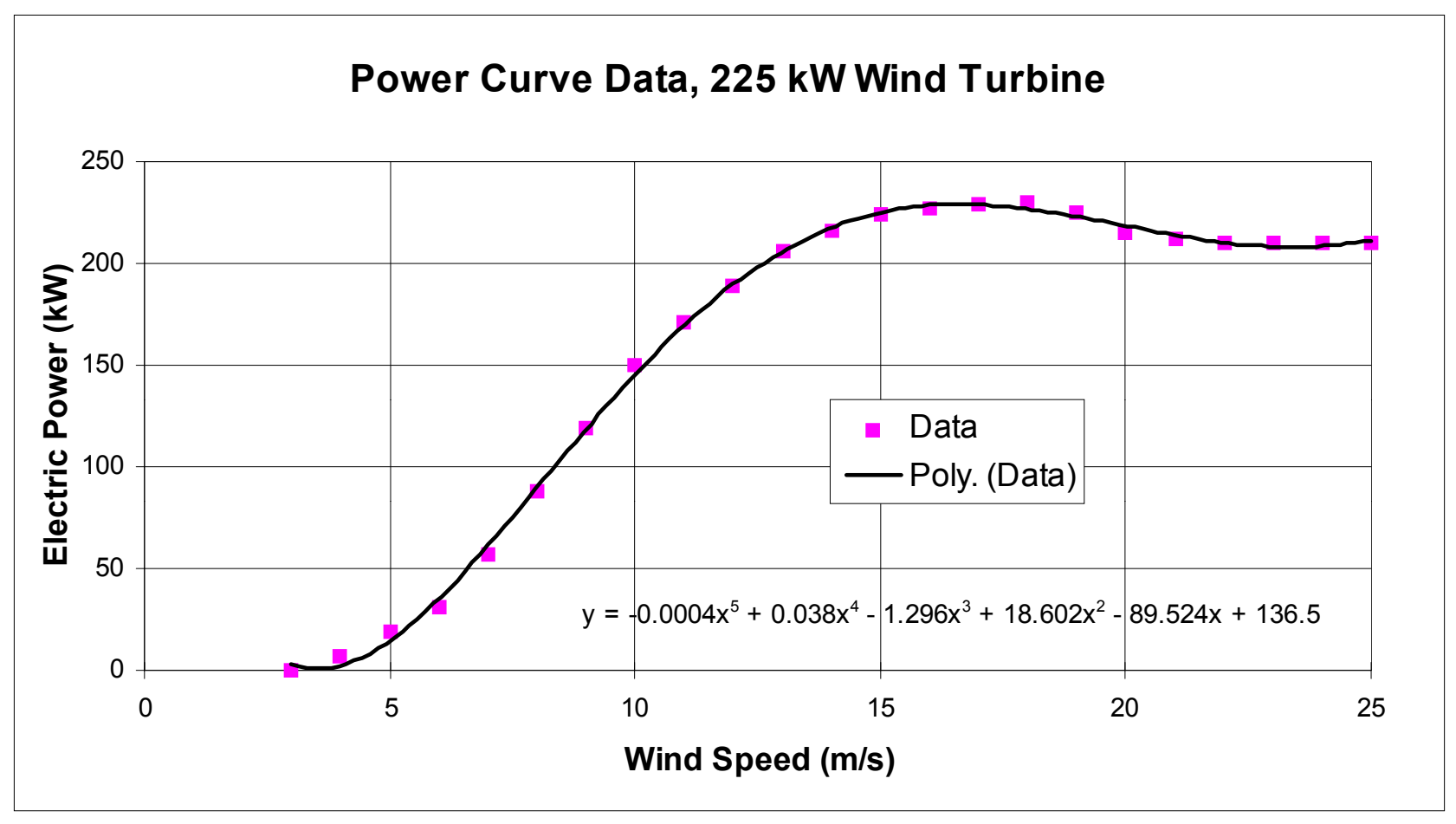

Figure 30: Power Curve, NM 225-30 (225 kW) Wind Turbine

\subsection{Wind Energy vs Load Profile Correlation}

The hybrid system model used hourly load data derived by combining hourly diesel production data with wind production based on hourly wind speed data. The evidence of the power production statistics in Section 2.3 indicates the loads at SCI grew 10\% per year from 1996 through 1998. Several new buildings and facilities would indicate a more substantial load increase in 1999. The load frequency distribution was shown earlier in Figure 3.

Short-term load variability is defined as 0.135 based on the following rationale: the average load, $846 \mathrm{~kW}$, gives 1 sigma (one standard deviation) $=114 \mathrm{~kW}$ and 3 sigma $=342 \mathrm{~kW}$. These values would require very large operating margins. However, the change in demand from one hour to the next is lower using the derived SCI hourly demand data, with an average of $48 \mathrm{~kW}$ and a peak of $287 \mathrm{~kW}$. These fluctuations coincide with operating experience, which has demonstrated about 50 $\mathrm{kW}$ normal fluctuation and an occasional $100-\mathrm{kW}$ to $300-\mathrm{kW}$ demand step or spike. The hybrid spreadsheet model accommodates this fluctuation by reserving a $300-\mathrm{kW}$ margin of diesel capacity above the net demand for each 12-hour period.

The hourly wind speed averages from 1998 composite data set was used in the hybrid-system model. Both wind and load data were arranged to a calendar year to assure proper synchronization. The wind frequency distribution was presented earlier in Figure 14. Annual diurnal wind speed and load are overlaid in Figure 31. Both the diurnal load and wind speed are relatively steady, 
with the diurnal wind speed cycling between 5.4 and $7.7 \mathrm{~m} / \mathrm{s}$, giving a somewhat neutral correlation.

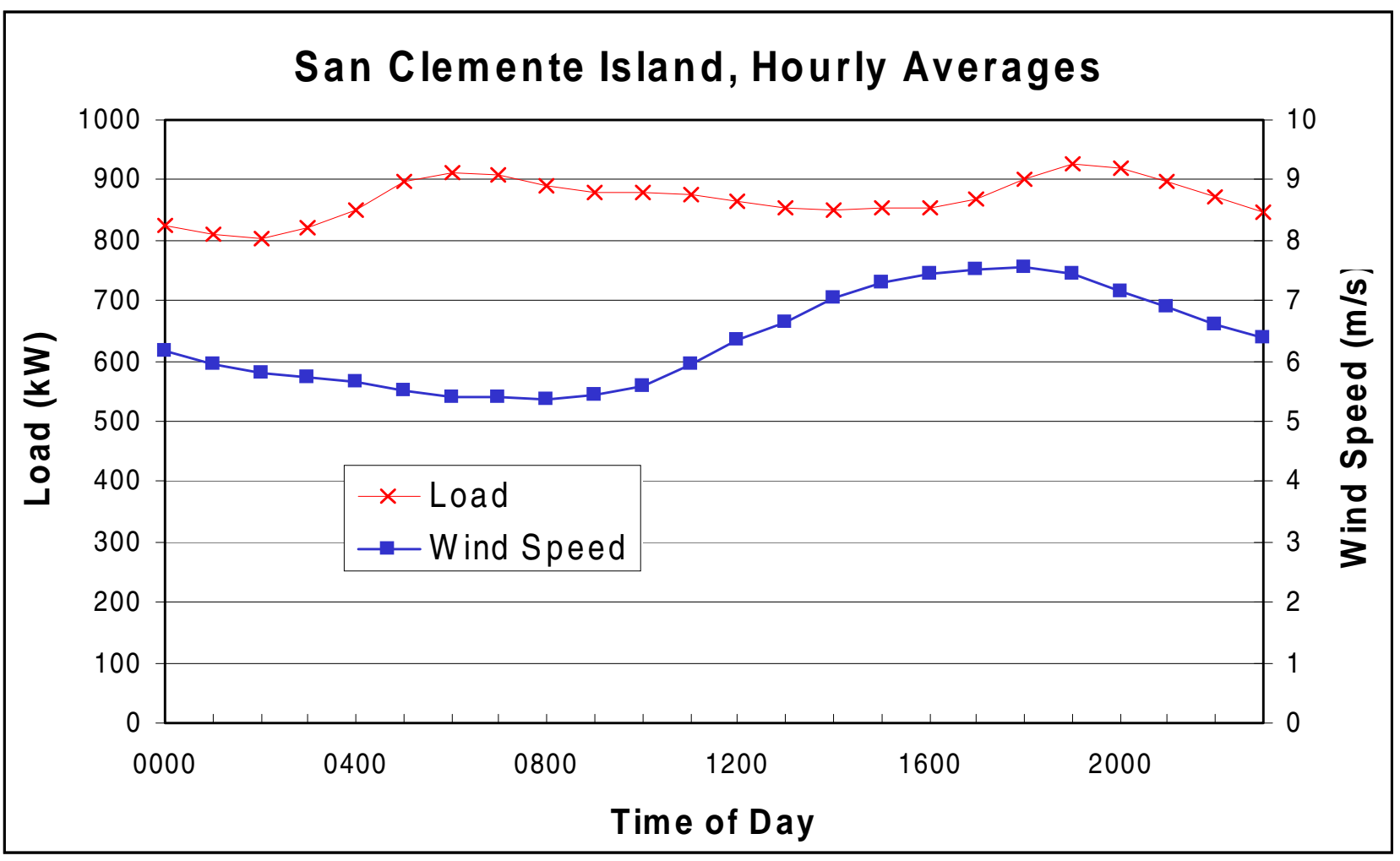

Figure 31: SCI Diurnal Load and Wind Speed Overlay

\subsection{Energy System Operating Results}

Using the first year's operating data with two $225 \mathrm{~kW}$ wind turbines (February 1998 through January 1999), the diesel energy production and fuel consumption fell by $11.2 \%$. More detail is given in the monthly power plant production logs in Appendix B. The wind turbines were not fully utilized during this time because of initial startup and adjustment activities and subsequent grid problems and construction activities.

\subsection{Hybrid System Spreadsheet Model}

The hybrid system model uses the existing wind-diesel system plus new wind generation; the load data are from SCI 1998 operating data and the wind data are from the NREL/SCI 1996 through 1999 measurements. The spreadsheet model starts by calculating a diesel rating that covers the load demand with sufficient margin to ensure a minimum diesel run time of 12 hours and capable of handling 400-kW excursions. Diesel consumption for a diesel-only baseline system is calculated next, based on demand and efficiency. Finally, the number of diesel starts and run time are computed. 
The wind-diesel hybrid section follows by calculating the power produced by a single wind turbine for each hour of the year. Then it calculates the optimal wind power usage by choosing the greatest number of turbines to operate without exceeding demand, and while maintaining at least $200 \mathrm{~kW}$ of diesel energy online. This wind power, when subtracted from the demand, reduces the amount of power required from the diesel generators. Only in very low or very high winds are the diesel power demand unchanged. Diesel fuel consumption is then calculated from this net demand and fed into the fuel savings over the baseline system.

Four different cases of the wind-diesel hybrid system were examined. The results are summarized in Table 5. In the first case, just one $225-\mathrm{kW}$ wind turbine was added to the baseline diesel system, the second case two $225-\mathrm{kW}$ turbines, and so on, up to four $225-\mathrm{kW}$ wind turbines. The minimum and maximum net loads (demand minus wind power) are $0 \mathrm{~kW}$ (loss of grid) and 1472 $\mathrm{kW}$ for all cases. The number of diesel starts is determined by incrementing a counter every time the diesel demand changes. The diesel run time is 8760 hours ( 1 diesel all year), plus the number of hours at $1700 \mathrm{~kW}$ capacity ( 2 diesels on). The diesel-only case required 100 starts and 15,491 engine-hours of total run time for the year.

Four $225 \mathrm{~kW}$ wind turbines reduce diesel energy production by $23.1 \%$ and fuel consumption by $17.0 \%$. Fuel savings fall below energy savings because the high wind variability necessitates greater diesel capacity running at somewhat less efficient conditions. However, these fuel savings could be improved significantly if the diesel usage was optimized, but at the cost of starting and stopping the engines much more frequently. 


\section{Table 5: 1998 Hybrid Systems vs Baseline: Spreadsheet Model Results}

\begin{tabular}{|c|c|c|c|c|c|c|}
\hline \multicolumn{2}{|l|}{ Hybrid Results } & $\begin{array}{r}\text { Baseline } \\
\text { Diesel } \\
\text { Only }\end{array}$ & $\begin{array}{l}1 \text { Wind } \\
\text { Turbine } \\
225 \mathrm{~kW}\end{array}$ & $\begin{array}{r}2 \text { Wind } \\
\text { Turbines } \\
225 \mathrm{~kW}\end{array}$ & $\begin{array}{r}3 \text { Wind } \\
\text { Turbines } \\
225 \mathrm{~kW} \\
\end{array}$ & $\begin{array}{r}4 \text { Wind } \\
\text { Turbines } \\
225 \mathrm{~kW}\end{array}$ \\
\hline Average WS, 1yr & $\mathrm{m} / \mathrm{s}$ & 6.1 & 6.1 & 6.1 & 6.1 & 6.1 \\
\hline Average Load, 1yr & $\mathrm{kW}$ & 870 & 870 & 870 & 870 & 870 \\
\hline Run Duration & hour & 8,760 & 8,760 & 8,760 & 8,760 & 8,760 \\
\hline Avg Net Diesel Load & $(1), \mathrm{kW}$ & 870 & 817 & 763 & 711 & 669 \\
\hline Energy Demand, 1yr & MWh & 7618 & 7618 & 7618 & 7618 & 7618 \\
\hline Diesel Energy, 1yr & MWh & 7618 & 7153 & 6687 & 6232 & 5856 \\
\hline Wind Energy, Used & MWh & 0 & 466 & 931 & 1386 & 1762 \\
\hline Wind Energy, Unused & $\mathrm{MWh}$ & 0 & 0 & 0 & 10 & 100 \\
\hline Diesel Energy & $\%$ & 100.0 & 93.9 & 87.8 & 81.8 & 76.9 \\
\hline Wind Energy & $\%$ & 0.0 & 6.1 & 12.2 & 18.2 & 23.1 \\
\hline Wind Energy Increme & ntal Turbine & e $\% 0.0$ & 6.1 & 6.1 & 6.0 & 4.9 \\
\hline Wind System Capacit & y Factor $\%$ & (2) $\mathrm{n} / \mathrm{a}$ & 23.6 & 23.6 & 23.4 & 22.3 \\
\hline Wind Sys Inctl Turbin & le Cap Fac \% & $\mathrm{n} / \mathrm{a}$ & 23.6 & 23.6 & 23.1 & 19.1 \\
\hline Fuel Usage & kltr & 2689 & 2568 & 2447 & 2329 & 2232 \\
\hline Fuel Usage & $\%$ of base & 0.0 & 95.5 & 91.0 & 86.6 & 83.0 \\
\hline Fuel Saving & kltr & 0 & 121 & 242 & 360 & 457 \\
\hline Wind Energy COE & $\$ / \mathrm{kWh}$ & $\mathrm{n} / \mathrm{a}$ & 0.152 & 0.142 & 0.138 & 0.139 \\
\hline Effective Wind COE & (3), \$/kWh & $\mathrm{n} / \mathrm{a}$ & 0.361 & 0.353 & 0.350 & 0.351 \\
\hline Hybrid System COE & $\$ / \mathrm{kWh}$ & 0.476 & 0.469 & 0.461 & 0.453 & 0.447 \\
\hline System COE Saving & $\$ / \mathrm{kWh}$ & 0.000 & 0.007 & 0.015 & 0.023 & 0.029 \\
\hline System COE Saving & $\%$ of base & 0.0 & 1.5 & 3.2 & 4.8 & 6.1 \\
\hline Payback Period & year & $\mathrm{n} / \mathrm{a}$ & 7.00 & 6.49 & 6.28 & 6.32 \\
\hline Internal Rate of Retur & $n, \%$ & $\mathrm{n} / \mathrm{a}$ & 13.1 & 14.4 & 14.9 & 14.8 \\
\hline
\end{tabular}

Notes:

(1) "Net Diesel Load" means net power required from the diesels, or system load minus useable wind power.

(2) Wind System Capacity Factor = Wind Energy [MWh] /

(\#turbines*rating[0.225MW]*8760[h]).

(3) Effective Wind Cost of Energy $(\mathrm{COE})=$ (hybrid COE*energy demand - baseline $\mathrm{COE}^{*}$ diesel energy) / wind energy.

(4) All other values derived from spreadsheet model results, Appendix A.

(5) For efficiency, this table includes some of the economic results developed and discussed in the next section. 


\subsection{COST ANALYSIS}

\subsection{Methodology}

After estimating 1998 operating costs for the four cases of the wind-diesel hybrid system and for the baseline diesel-only system, the resulting levelized costs of energy (COE) were compared. Also, payback periods were computed for the four cases of hybrid system investment. COE is derived using

$$
\mathrm{COE}=\mathrm{NPV} * \mathrm{CRFI} / \mathrm{AEP}
$$

where NPV is the total net present value of all system costs, CRFI is the capital recovery factor for system income, and AEP is annual energy production (system load). A simple payback period is calculated by dividing the total initial capital cost by the annual savings from system operation, which includes the difference in fuel, overhaul, and operations and maintenance (O\&M) costs between the wind-diesel hybrid and baseline systems [4].

Economic assumptions included 2\% general inflation, 2\% fuel inflation, 6.9\% discount rate, 20 year system life, and $100 \%$ down payment on new investment. Although new wind turbines will start with a 20 -year life, the existing diesel systems have been in service for several years and have limited lives of their own. This is covered by a fund for major diesel overhauls. It was further assumed that no additional labor would be required to operate the wind-diesel hybrid plant beyond that already assigned to operate the existing diesel power plant.

\subsection{Diesel System Costs}

The diesel system operating costs are derived partly from San Nicolas Island cost data because the San Clemente Island information is incomplete. Fuel costs are based on various memos, email and verbal conversations with the PWC.

Since a full breakdown of SCI power system costs was not available, we resorted to the rate SCI charges its customers: $\$ 0.390$ / $\mathrm{kWh}$, which gives $\$ 2,971,205$ for $7,618,475 \mathrm{kWh}$. The inherent assumption is that this rate reflects true and total life-cycle costs for the SCI power system without profit, since its customers are other Navy entities and their subcontractors. We suspect the true diesel system costs are lower, but don't have any other basis to work with at this time.

The fuel price also is known, at $\$ 0.206 /$ liter $(\$ 0.78 /$ gal), and adding transportation and other hidden costs bring the total fuel cost up to $\$ 0.264 /$ liter $(\$ 1.00 /$ gal). That translates into $\$ 0.082$ / $\mathrm{kWh}$ for fuel using the baseline fuel and energy totals for 1998. The remaining amount of $\$ 0.308 /$ $\mathrm{kWh}$ is included in the O\&M item in the economic analysis spreadsheet, but it must cover O\&M, diesel overhauls, and eventual replacement. However, some of these costs are fixed and part variable. We will assume they split half-and-half, based on experience with similar facilities [5]. Therefore the variable part is $\$ 0.154 / \mathrm{kWh}$, and the fixed part is $0.5 *(0.308 * 7,618,475)=$ $\$ 1,173,245$. 


\subsection{Wind Energy System Costs}

Wind-diesel hybrid system costs include the baseline costs as given above, plus new costs associated with the wind turbines and interconnect and control equipment. The interconnect and control equipment are included with the wind turbine balance of station (BOS) costs, along with foundations, installation, spare parts inventory, site surveying and preparation, O\&M facilities and equipment, permits and licenses, project management and engineering, and construction insurance and contingency. Initial capital costs including BOS are detailed in Table 6. If multiple turbines were installed at one time, per-unit turbine price and BOS costs would drop considerably, but we have not applied this adjustment. Also, it may be possible to further reduce installation and operation costs by utilizing Navy heavy equipment (such as a crane).

Each $225 \mathrm{~kW}$ wind turbine costs $\$ 220,000$, plus $\$ 25,000$ shipping from Denmark to Los Angeles then to SCI. An additional $\$ 450,510$ is required to cover BOS costs. Thus, the total capital cost required for four wind turbines is $\$ 2,742,040$, when installed one at a time. If all four turbines were installed together, the overall cost would be about $\$ 2,500,000$. Overhaul costs are fixed at an annual $\$ 1000$ per wind turbine, regardless of turbine usage. Actual wind turbine O\&M costs of $\$ 0.005 / \mathrm{kWh}$ are doubled to $\$ 0.01 / \mathrm{kWh}$ to account for the small system size and the extra burden SCI represents with its remote setting. As implied by its units, this O\&M cost is variable, or fully dependent on wind turbine usage. These amounts are based on a working system using the 225 $\mathrm{kW}$ wind turbine.

\section{Table 6: Initial Capital Costs for One Additional 225 kW Wind Turbine}

\begin{tabular}{lrrr} 
Item & $\begin{array}{c}\text { Mainland } \\
\text { Cost }\end{array}$ & $\begin{array}{c}\text { Extra Cost for } \\
\text { SCI Access }\end{array}$ & $\begin{array}{r}\text { Total SCI } \\
\text { Cost 1998 }\end{array}$ \\
\hline 225kW Wind Turbine & $\$ 220,000$ & $\$ 25,000$ & $\$ 245,000$ \\
Turbine installation on SCI & 75,000 & 67,180 & 142,180 \\
225kW Service Parts & 3,000 & 400 & 3,400 \\
Turbine Maintenance / Warranty & 2,000 & 2,730 & 4,730 \\
Turbine Siting & 3,100 & 2,000 & 5,100 \\
Turbine Foundation & 90,000 & 41,000 & 131,000 \\
Project Engineering & 25,000 & 5,500 & 30,500 \\
Trenching \& Land Improvements & 5,000 & 8000 & 13,000 \\
Electrical Infrastructure & 80,000 & 23,000 & 103,000 \\
Electrical Maintenance / Warranty & 4,000 & 3,600 & 7,600 \\
Total & 507,100 & 178,410 & $\$ 685,510$
\end{tabular}

If multiple turbines were installed together, a discount should be available on the wind turbines, and significant economies of scale would be possible with the BOS costs. Based on bids for multiple turbine projects at SCI, the initial capital cost for one wind turbine should drop by $\$ 50,000$ each for two turbines, $\$ 75,000$ each for three, and $\$ 100,000$ each for four. These 
reductions are used in the economic model. However, the wind farm at SCI began with two units and will have a third and a fourth added at different times.

\subsection{Wind-Diesel Hybrid System Operational Savings}

Once all of the engineering and cost data were ready, an economic assessment was performed according to the procedure used in Hunter [4]. Figure 32 shows the resulting COE decreasing as the number of wind turbines increases. The trend will eventually reverse and start to increase with number of turbines, each additional wind turbine would be less efficiently utilized because of the growing wind energy penetration and lack of system storage. For this same reason, Figures 33 and 34 show the payback period dropping and the internal rate of return rising from one to three turbines and then leveling and reversing thereafter. The complete economic tables can be found in Appendix A. These results are provided for those who need data points to check their own simulations. Copies of the spreadsheets used here can be obtained from the authors.

The $\$ 1,271,000$ capital investment in the two-turbine hybrid system was easily offset by savings in fuel and operating costs for diesel generation of $\$ 196,000$ annually, giving a 6.49 year simple payback period, $14.4 \%$ internal rate of return, $\$ 0.142 / \mathrm{kWh}$ wind $\mathrm{COE}$, and dropping the system COE from $\$ 0.476 / \mathrm{kWh}$ to $\$ 0.461 / \mathrm{kWh}$. This would give net savings of $\$ 0.015 / \mathrm{kWh}$, or $\$ 114,000$ in 1998. Using the EPRI TAG approach gives a wind energy $\mathrm{COE}=(\mathrm{ICC} * \mathrm{FCR}) / \mathrm{AEP}+\mathrm{O} \& \mathrm{M}=$ $(635510 * .102) / 466000+0.01=\$ 0.149 / \mathrm{kWh}$.

With a capital investment of $\$ 2,342,000$, four $225 \mathrm{~kW}$ wind turbines have annual operating savings of $\$ 370,000$, and would give a 6.32 year simple payback period, $14.8 \%$ internal rate of return, $\$ 0.139 / \mathrm{kWh}$ wind COE, and $\$ 0.447 / \mathrm{kWh}$ system COE, with net savings of $\$ 0.029 / \mathrm{kWh}$, or $\$ 223,000$ in 1998 . 


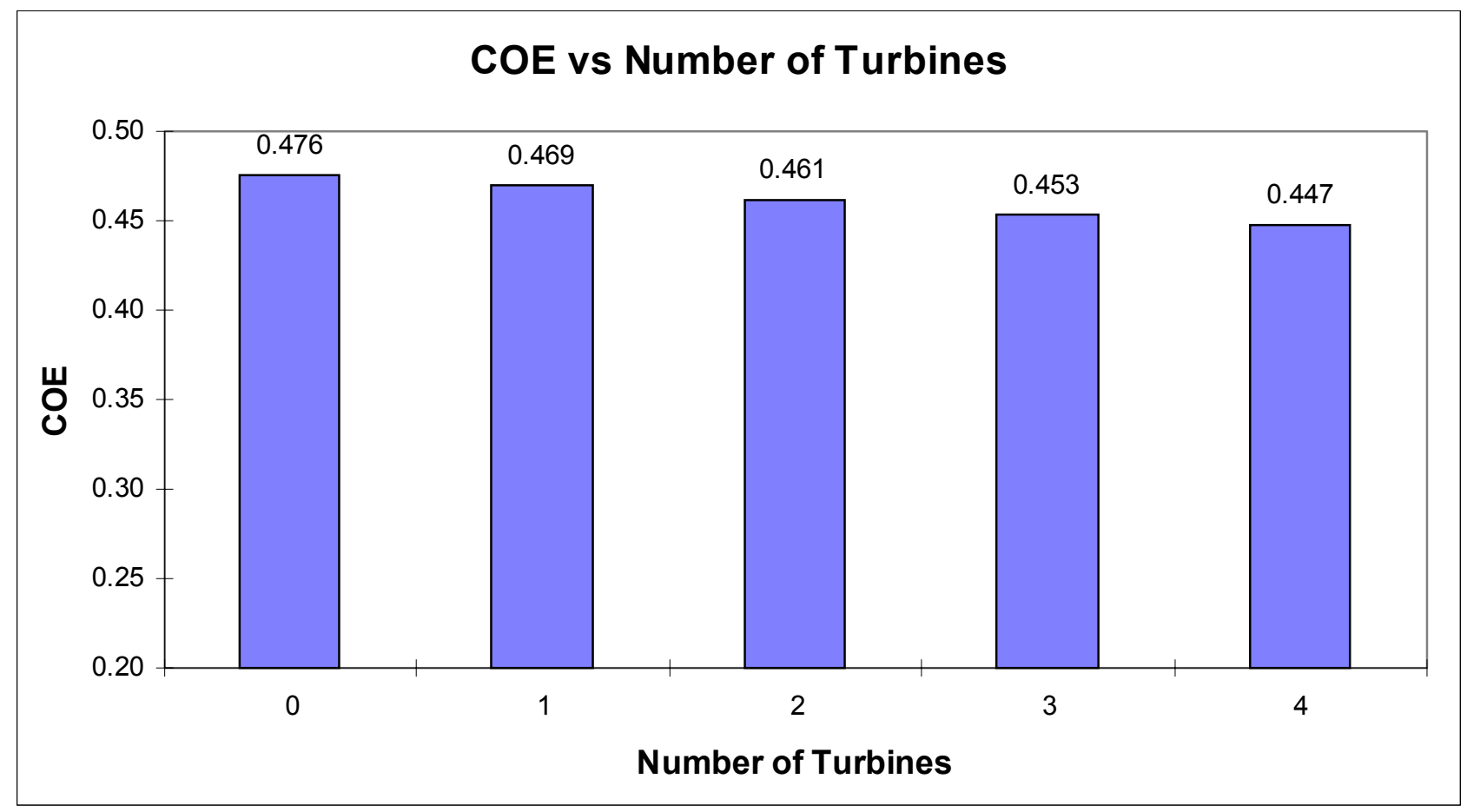

Figure 32: System COE vs Number of Wind Turbines

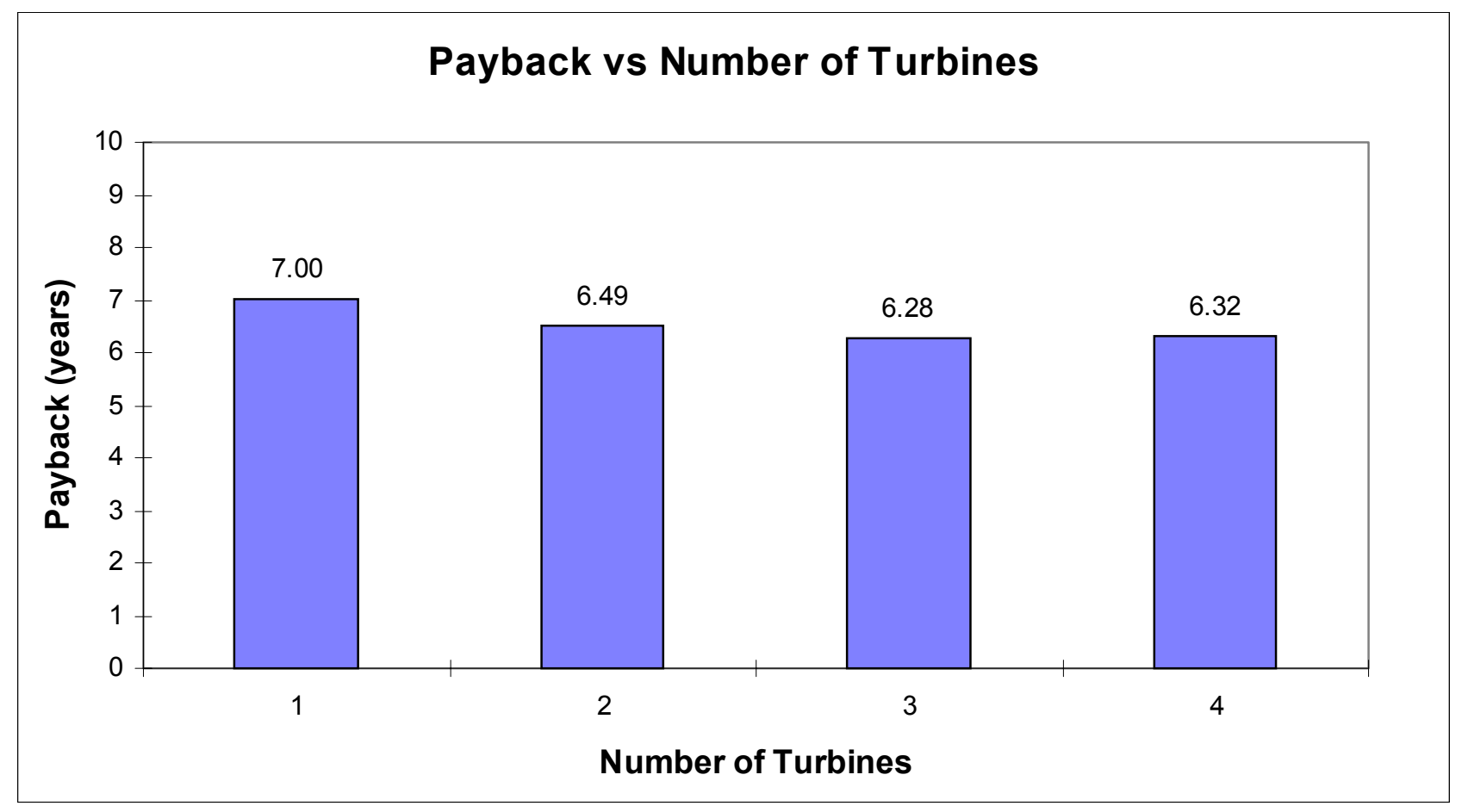

Figure 33: Payback Period vs Number of Wind Turbines 


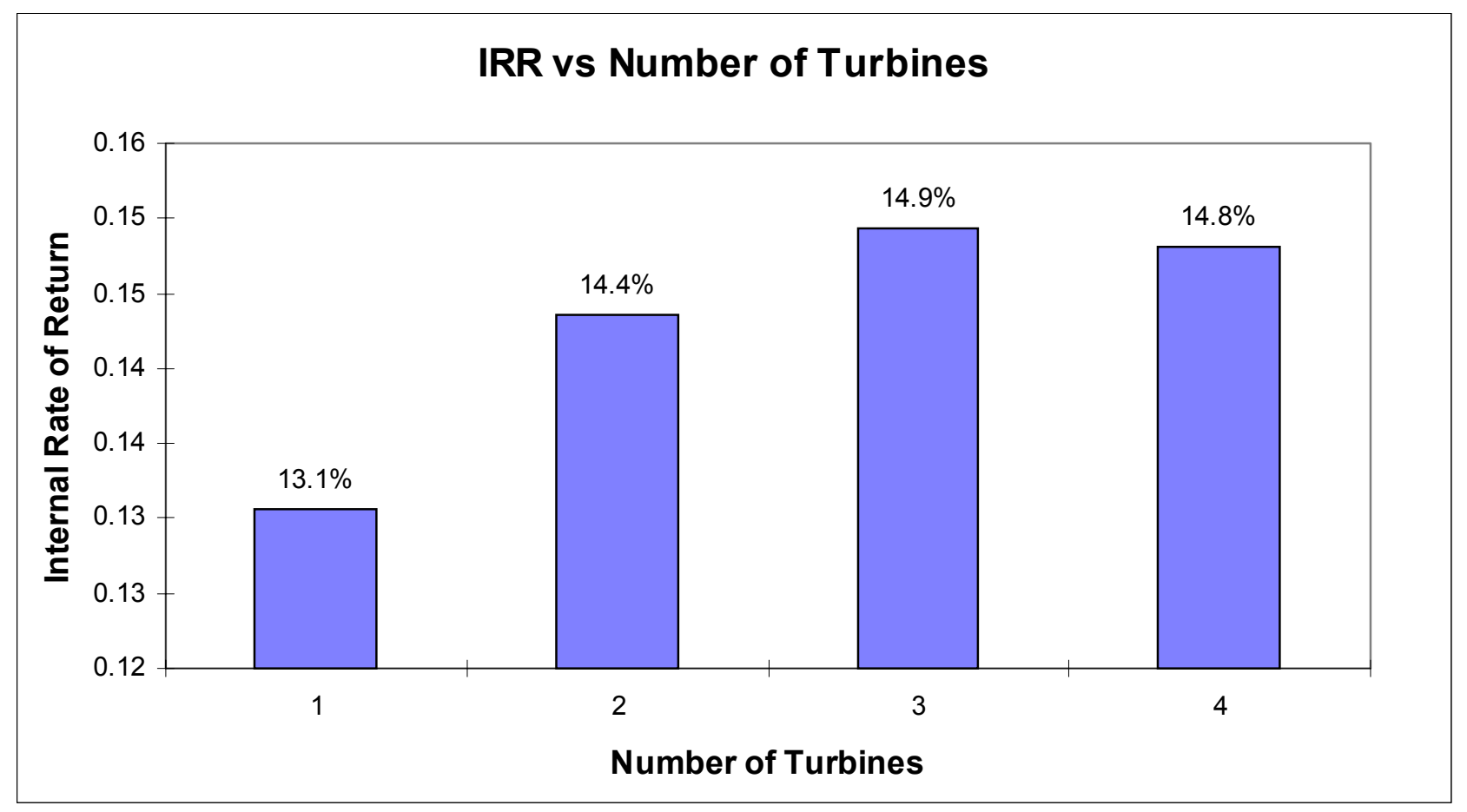

Figure 34: Internal Rate of Return vs Number of Wind Turbines

\subsection{Sensitivity Analysis}

To check the sensitivity of the results to variations in average wind speed from year to year, the two-turbine case was run with the wind speeds adjusted upward and downward by $17.5 \%$, which is the interannual variability (one standard deviation) found in the historical wind measurements. The results are shown in Table 7 . With the wind speed $17.5 \%$ lower than the NREL measurement year, $\mathrm{COE}$ and payback period rose by $2.6 \%$ and $63 \%$. With the wind speed $17.5 \%$ higher, COE and payback period dropped by $2.6 \%$ and $28 \%$.

Table 7: Economic Sensitivity to Wind Speed Variations

Spreadsheet Model for 2 Turbines

\begin{tabular}{lccccc} 
Case & $\begin{array}{c}\text { Diesel } \\
\text { Saving } \\
(\mathrm{kltr})\end{array}$ & $\begin{array}{c}\text { Cost of } \\
\text { Energy } \\
(\$ / \mathrm{kWh})\end{array}$ & $\begin{array}{c}\text { Payback } \\
\text { Period } \\
(\text { years })\end{array}$ & $\begin{array}{c}\text { Internal } \\
\text { Rate of } \\
\text { Return }(\%)\end{array}$ \\
\hline minus $17.5 \%$ & $5.0 \mathrm{~m} / \mathrm{s}$ & 149 & 0.473 & 10.6 & 7.0 \\
baseline & $6.1 \mathrm{~m} / \mathrm{s}$ & 242 & 0.461 & 6.5 & 14.4 \\
plus $17.5 \%$ & $7.2 \mathrm{~m} / \mathrm{s}$ & 336 & 0.449 & 4.7 & 21.0
\end{tabular}


The wind energy COE of $\$ 0.15 / \mathrm{kWh}$ is much higher than the typical range of $\$ 0.04 / \mathrm{kWh}$ to $\$ 0.09 / \mathrm{kWh}$. Several factors contribute to this discrepancy, including costs associated with island access, severe Naval construction requirements, and moderately low wind speeds at this site. To gain some understanding of the COE sensitivity to these issues, we ran an economic case for two turbines without the severe Naval and island access requirements. This case uses mainland costs with those for installation, foundation, and electrical infrastructure reduced by half, plus a $\$ 30,000$ discount for each of two turbines. The net initial capital cost of $\$ 354,600$ per turbine generates a wind energy COE of $\$ 0.086 / \mathrm{kWh}$, a hybrid system COE of $\$ 0.454 / \mathrm{kWh}$, a payback period of 3.6 years, and a $27.4 \%$ internal rate of return. Using the EPRI TAG approach gives $\mathrm{COE}=$ $(\mathrm{ICC} * \mathrm{FCR}) / \mathrm{AEP}+\mathrm{O} \& \mathrm{M}=(354600 * .102) / 466000+0.01=\$ 0.088 / \mathrm{kWh}$.

\subsection{CONCLUSIONS}

San Clemente Island (SCI) has a moderate wind resource, with an annual average wind speed of $6.1 \mathrm{~m} / \mathrm{s}$ (11.6 knots) as measured by the National Renewable Energy Laboratory and the Naval Facilities Engineering Service Center at the Met2 tower wind site location from the 1995 through 1999 data collection period. Recognizing this, the recently constructed wind-diesel hybrid energy system was modeled to examine its performance and economics, as well as the merits of adding more wind energy generation. Using generally conservative assumptions (unfavorable to wind energy) in the model, the hybrid system displayed favorable operation and economics.

Using two $225 \mathrm{~kW}$ wind turbines, the wind energy COE of $\$ 0.142 / \mathrm{kWh}$ helps reduce the winddiesel hybrid system COE from the baseline $\$ 0.476 / \mathrm{kWh}$ to $\$ 0.461 / \mathrm{kWh}$. This reduces system COE by $3.2 \%$. The payback period is 6.5 years, the internal rate of return $14.4 \%$. The four-turbine case had a wind energy COE of $\$ 0.139 / \mathrm{kWh}$ and a hybrid system COE of $\$ 0.447 / \mathrm{kWh}$, saving $6.1 \%$. The payback period is 6.3 years, the internal rate of return $14.8 \%$.

The costs of energy (COE) for this case is relatively insensitive to annual average wind speed, varying $2.6 \%$ for a $17.5 \%$ change in wind speed. But the payback period is quite sensitive to wind speed, varying $28 \%$ to $63 \%$ for a $17.5 \%$ change in wind speed. Different economic assumptions, such as higher and lower inflation, do not appear to have much impact on the results. Because cost and savings components are well distributed, there does not appear to be a dominant factor affecting the economic results. Factors that could affect the results include the actual capital and installation costs of the wind equipment, diesel fuel costs, and diesel system O\&M and overhaul costs.

This work presented a study of the SCI wind-diesel hybrid system using two wind turbines with an option for two more. For the operating and economic conditions examined, it appears wind energy is cost effective in this application. We believe these conditions are realistic but regret the lack of complete cost data on the existing diesel system. Certainly many alternatives to these cases merit consideration. For instance, it appears that the wind penetration could be increased, thus producing further, yet diminishing, savings. 
Moreover, excess electrical energy should not be curtailed or wasted on dump loads; rather, it should be used for beneficial purposes, provided those purposes make economic sense. Within the SCI electrical grid, such benefits may be realized by using excess wind energy for deferrable loads such as the SCI reverse osmosis water system, water heating, or space heating. The Navy is planning for a reverse osmosis water system with its fourth wind turbine in 2001.

As a preliminary review, this study used 1-hour average wind and load data for the hybrid system modeling to develop a general sense of economic tradeoffs. Dynamic load management should be addressed using load and wind data at shorter intervals (1 minute or less) to study system dynamics. 


\section{REFERENCES}

1. Marriott, Ken, et al (1983). Operational / Land Use Compatibility Study for NALF San Clemente Island, KTU+A under Southwest Division Contract \# N68711-91-C-0035 for USN NAS North Island Staff Civil Engineers.

2. Elliott, D.L., et al. (1987). Wind Energy Resource Atlas of the United States, DOE/CH10093-4, Pacific Northwest Laboratory.

3. Pal, D. and Casteel, F. (1986). Wind Resource Assessment for Naval Auxiliary Landing Field, San Clemente Island, California, TM M-73-86-10, Navy Energy and Natural Resources R\&D Office, Naval Facilities Engineering Command.

4. Hunter, R. and Elliott, G. (1994). Wind Diesel Systems, Cambridge University Press.

5. Olsen, T and McKenna, E (1996). Hybrid Energy System Cost Analysis: San Nicolas Island, California, NREL/TP-440-21120.

6. Miller, Alan (1996). The Evaluation of the Wind Resource at San Nicolas Island, report to NREL, Problem Solvers, International, Golden, Colorado. 


\section{APPENDIX A: \\ Hybrid System Model and Economic Summary Tables}

This appendix contains the hybrid system model and economic summary tables used to develop the economic conclusions reached in this report. 
SAN CLEMENTE ISLAND HYBRID SYSTEM MODEL

Maxdmum number of wind lutines: 1

\begin{tabular}{|c|c|c|c|c|c|c|c|c|c|c|c|c|c|c|c|c|c|c|}
\hline $\begin{array}{l}7 m e \\
(\mathrm{hr})\end{array}$ & $\begin{array}{l}\text { Demand } \\
\text { (WW }\end{array}$ & $\begin{array}{l}\text { Diesel } \\
\text { fating } \\
(\mathrm{hW})\end{array}$ & $\begin{array}{l}\text { Percent of } \\
\text { Rating } \\
\text { Used }\end{array}$ & $\begin{array}{l}\text { Litres of } \\
\text { Oiesel } \\
\text { Consumed }\end{array}$ & $\begin{array}{l}\text { starts } \\
\text { counter }\end{array}$ & $\begin{array}{l}\text { Diosel } \\
\text { run time } \\
\text { (houre) }\end{array}$ & $\begin{array}{l}\text { Adiuoted } \\
\text { Wind } \\
\text { Spoed } \\
\text { (m/s) }\end{array}$ & $\begin{array}{l}\text { Wind hybrid- } \\
\text { Single } \\
\text { Turbine } \\
\text { Wind } \\
\text { Power } \\
\text { (kW) }\end{array}$ & $\begin{array}{l}\text { Maximum } \\
\text { Allowod } \\
\text { Wind } \\
\text { Demand } \\
\text { (kW) }\end{array}$ & $\begin{array}{l}\text { Number } \\
\text { of } \\
\text { Turbined }\end{array}$ & $\begin{array}{l}\text { Not } \\
\text { Demand } \\
(\mathbf{K W})\end{array}$ & $\begin{array}{l}\text { Dlesel } \\
\text { Pating } \\
(\mathrm{kW})\end{array}$ & $\begin{array}{l}\text { Percent of } \\
\text { Rating } \\
\text { Ueod }\end{array}$ & $\begin{array}{l}\text { Litres of } \\
\text { Diesel } \\
\text { Consumed }\end{array}$ & $\begin{array}{l}\text { etarte } \\
\text { counter }\end{array}$ & $\begin{array}{l}\text { Diesel } \\
\text { run time } \\
\text { (hours) }\end{array}$ & $\begin{array}{l}\text { litreo } \\
\text { saved }\end{array}$ & $\begin{array}{l}98.4 \mathrm{ft} \\
\text { Onginal } \\
\text { Wind } \\
\text { Speed } \\
6.1 \mathrm{~m} / \mathrm{s}\end{array}$ \\
\hline rerage & 069.7 & 1531.7 & $58 \%$ & 308.6 & & & 6.1 & 53.1 & 669.7 & 0.8 & 816.5 & 1448.9 & 0.5 & 293.2 & & & & \\
\hline andard Deviation & 114,0 & 236.9 & $8 \%$ & 37.8 & & & 3.1 & 60.9 & $\$ 14,0$ & 0.4 & 107.0 & 250.0 & 0.1 & 35.5 & & & 15.80659 & 3.108 \\
\hline Meximum & 1519.1 & 1700.0 & $60 \%$ & 484.3 & & & 21.6 & 229.4 & 1319.1 & 1.0 & 1289.8 & 1700.0 & 0.8 & 424.9 & & & 59.48818 & 21.62711 \\
\hline Minimum & 514.2 & 1200.0 & $32 \%$ & 197.1 & & & 0.3 & 0.0 & 314.2 & 0.0 & 489.8 & 1200.0 & 0.3 & 197.1 & & & 0 & 0.300872 \\
\hline Total & 7618476 & & & 2688873 & 190 & 14572 & & 465547 & 5868476 & & 7152929 & & & 2568122 & 220 & 13121 & 120751 & \\
\hline
\end{tabular}

468547 Wind Energy Uaod

465547 Wind Energy Available

D Wnd Energy Curtailad

Maximum number of wind authes: 2

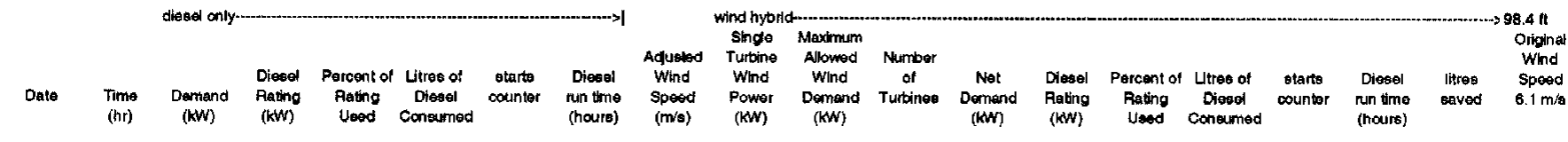

\begin{tabular}{|c|c|c|c|c|c|c|c|c|c|c|c|c|c|c|c|c|c|}
\hline Averago & 869.7 & 1531.7 & $58 \%$ & 300.8 & & & 6.1 & 53.1 & 609.7 & 1.7 & 763.4 & 1393.1 & 0.5 & 279.4 & & 27.5688 & 0.119481 \\
\hline Standard Deviation & 114.0 & 236.3 & $8 \%$ & 37.8 & & & 3.1 & 60.8 & 114.0 & 0.7 & 131.6 & 243.6 & 0.1 & 39.8 & & 31.81318 & 3.10947 \\
\hline Maxamum & 1519.1 & 1700.0 & $88 \%$ & 484.3 & & & 21.6 & 229.4 & 1319.1 & 2.0 & 1277.8 & 1700.0 & 0.8 & 421.7 & & 119 & 21.62711 \\
\hline Minimum & 514.2 & 1200.0 & $32 \%$ & 197.1 & & & 0.3 & 0.0 & 314.2 & 0.0 & 281.1 & 750.0 & 0.2 & 154.8 & & 0 & 0.300872 \\
\hline Total & 7618476 & & & 2688873 & 196 & 14572 & & 465547 & 5866476 & & 6687381 & & & 2447371 & 236 & 241503 & \\
\hline
\end{tabular}

931095 Wind Energy Ueod

931095 Wind Energy Available
0 Wind Energy Cuttailed

Maximum number of wind thitineo: 3

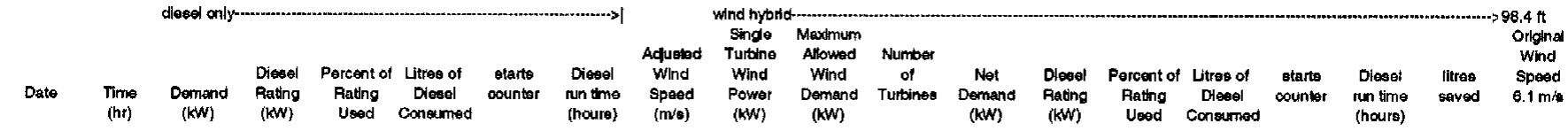

$\begin{array}{lrrrrrr}\text { Average } & 869.7 & 1531.7 & \mathbf{5 8 \%} & 308.8 & & \\ \text { Standard Deviation } & 114.0 & 238.3 & 8 \% & 37.9 & & \\ \text { Maximum } & 1519.1 & 1700.0 & 89 \% & 484.3 & & \\ \text { Minimum } & 514.2 & 1200.0 & \mathbf{3 2 \%} & 197.1 & & \\ \text { Total } & 7618476 & & & 2688973 & 190 & 14572\end{array}$

$\begin{array}{rrr}6.1 & 53.1 & 669.7 \\ 3.1 & 60.9 & 114.0 \\ 21.6 & 229.4 & 1319.1 \\ 0.3 & 0.0 & 314.2 \\ & 465547 & 5868476\end{array}$

$\begin{array}{rrr}2.5 & 711.4 & 1355.1 \\ 1.1 & 172.0 & 247.3 \\ 3.0 & 1277.8 & 1700.0 \\ 0.0 & 201.0 & 760.0 \\ & 6232205 & \end{array}$

$\begin{array}{rr}0.5 & 265.9 \\ 0.1 & 48.3 \\ 0.8 & 421.7 \\ 0.1 & 116.1 \\ & 2329309\end{array}$

416.119481

$\begin{array}{rr}46.75209 & 3.10947 \\ 178.4645 & 21.62711\end{array}$

1386271 Wind Energy Used

1396842 Wind Energy Available

Maximum numbes of wind altines: 4

t037: Wind

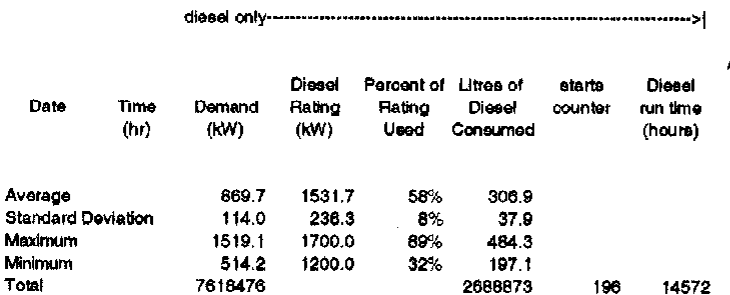

\begin{tabular}{|c|c|c|c|c|c|c|c|c|c|c|c|}
\hline $\begin{array}{l}\text { Adutiod } \\
\text { Wind } \\
\text { Spood }\end{array}$ & $\begin{array}{l}\text { Singe } \\
\text { Turthe } \\
\text { Wind } \\
\text { Power } \\
\text { (kW) }\end{array}$ & $\begin{array}{l}\text { Moximum } \\
\text { Allowod } \\
\text { Wind } \\
\text { Demand } \\
(\mathrm{kW})\end{array}$ & $\begin{array}{l}\text { Number } \\
\text { of } \\
\text { Turbines }\end{array}$ & $\begin{array}{c}\text { Net } \\
\text { Demand } \\
\text { f(KW) }\end{array}$ & $\begin{array}{l}\text { Diesel } \\
\text { Rating } \\
\text { (kW) }\end{array}$ & $\begin{array}{l}\text { Percent of } \\
\text { Rating }\end{array}$ & $\begin{array}{l}\text { Utree of } \\
\text { Olesel }\end{array}$ & $\begin{array}{l}\text { etarti } \\
\text { counber }\end{array}$ & $\begin{array}{l}\text { Dieed } \\
\text { nun time } \\
\text { fhore }\end{array}$ & $\begin{array}{l}\text { litreos } \\
\text { seved }\end{array}$ & $\begin{array}{l}\text { Original } \\
\text { Wind } \\
\text { Spood } \\
8.1 \mathrm{~m} / \mathrm{s}\end{array}$ \\
\hline
\end{tabular}

6.1
3.1
21.6
0.3

$\begin{array}{rr}53.1 & 689.7 \\ 60.9 & 114.0 \\ 229.4 & 1319.1 \\ 0.0 & 314.2 \\ 465547 & 5866476\end{array}$

$\begin{array}{rrr}3.3 & 668.5 & 1326.3 \\ 1.4 & 201.7 & 259.2 \\ 4.0 & 1277.8 & 1700.0 \\ 0.0 & 200.2 & 750.0\end{array}$

$\begin{array}{lr}0.4 & 254.8 \\ 0.1 & 55.0 \\ 0.8 & 421.7 \\ 0.1 & 116.1 \\ & 2231808\end{array}$

526.11948

5856374

$\begin{array}{rr}57.26681 & 3.10947 \\ 237.9527 & 21.6271\end{array}$

1762102 Wind Energy Used

1862189 Wind Energy Availab

100087 Wind Energy Curtalled 


\section{ECONOMIC ANALYSIS}

\section{Input Values}

System load (kWh/y)

Diesel energy $(\mathrm{kWh} / \mathrm{y})$

Wind energy $(\mathrm{kWh} / \mathrm{y})$

Diesel fuel usage, no wind $(\mathrm{I} / \mathrm{yr}) \quad \mathrm{FL} \quad 2,688,873$

Diesel fuel usage, with wind (I/yr) $F$

Diesel fuel cost (\$/I)

Diesel ops cost, variable $(\$ / k W h)$ OV

Diesel ops cost, fixed (\$/y)

Wind ICC (\$)

Wind O\&M cost $(\$ / \mathrm{kWh})$

System life, (yrs)

General inflation

Fuel inflation

Discount rate

Interest

Term of loan, (yrs)

\section{Quantity:}

\section{1}

$\begin{array}{lr}\text { SL } & 7,618,476 \\ & 7,152,929 \\ \text { FL } & 465,547 \\ \text { FL } & 2,688,873 \\ \text { FC } & 2,568,122 \\ \text { OV } & 0.264 \\ \text { OF } & 0.154 \\ \text { WC } & 1,173,245 \\ \text { WO } & 685,510 \\ \text { L } & 0.01 \\ \text { i } & 20 \\ \text { e } & 2.0 \% \\ \text { d } & 2.0 \% \\ \text { b } & 6.9 \% \\ \text { N } & 10.0 \% \\ \end{array}$

Site: $\quad$ San Clemente Island, CA, $6.1 \mathrm{~m} / \mathrm{s}$ avg

Turbine: 225 kW, Commercial

\section{Economic Factors}

Present worth factor of fuel costs, PWFF, $a=(1+e) /(1+d)$ Present worth factor of O\&M costs, PWFO, $a=(1+i) /(1+d)$

Present worth factor of interest payments, $P W F P, a=1 /(1+b)$

\begin{tabular}{|c|c|c|}
\hline$\underline{\text { a variable }}$ & $\underline{\mathrm{n} \text { variable }}$ & $Y(a, n)$ \\
\hline 0.95416277 & 20 & 12.67203 \\
\hline 0.95416277 & 20 & 12.67203 \\
\hline 0.9354537 & 10 & 7.05616 \\
\hline
\end{tabular}

\section{$\underline{\text { a variable }} \underline{\mathrm{n} \text { variable } \quad \underline{X(a, n)}}$}

Capital recovery factor for system income, CRFI, $a=1 /(1+d)$

Capital recovery factor for interest payments, CRFP, $a=1 /(1+b)$

$\begin{array}{lll}0.9354537 & 20 & 0.09366054 \\ 0.90909091 & 10 & 0.16274539\end{array}$

\section{Calculated Values for Both Systems}

\section{Capital cost}

Initial payment on system

Loan

NPV of annual payment

Fuel cost per annum

NPV of fuel costs

NPV of overhaul costs

O\&M costs per annum

NPV of O\&M costs

Total annual costs

Total system NPV, TNPV

Annual savings

Levelized cost of energy, COE

Payback period, years

Internal rate of return, IRR, $(x)$
Annual payment

Overhaul cost per annum

\begin{abstract}
$\mathrm{C}=\mathrm{ICC}+\mathrm{BOS}$
Ad

$\mathrm{Al}=\mathrm{C}-\mathrm{Ad}$

$A p=A l *$ CRFP

Apnpv $=$ Ap*PWFP

$\mathrm{Af}=\mathrm{FL}{ }^{*} \mathrm{FC}$

Afnpv $=A f *$ PWFF

Ao

Aonpv $=$ Ao * PWFO

Am

$A m n p v=A m * P W F O$

$A t=A p+A f+A o+A m$

$=A d+$ sum(NPVs)

Sv $=$ dsl At - hbd At

$=\mathrm{TNPV}{ }^{*} \mathrm{CRFI} / \mathrm{SL}$
\end{abstract}

$\left[(1+x)^{\wedge} L-1\right] /\left[x^{*}(1+x)^{\wedge} L\right]-P=$

$(\mathrm{NPV}=$ net present value $; \mathrm{ICC}=$ initial capitol cost; $\mathrm{BOS}=$ balance of station $=26 \%$ ICC; O\&M = operations and maintenance $)$
Diesel

Only

\begin{tabular}{r} 
Hybrid System \\
Diesel Part \\
\hline 0 \\
0 \\
0 \\
0 \\
0 \\
677,984 \\
$8,591,439$ \\
0 \\
0 \\
$2,274,796$ \\
$28,826,290$ \\
$2,952,780$ \\
$37,417,728$ \\
0.490
\end{tabular}

Hybrid System

Wind Part

685,510

685,510

0
0

0

0
1,000

12,672

4,655

58,994

5,655

$3,056,353$

$38,730,204$

0.476

0.152
Hybrid System

Total

685,510

685,510

0

0

677,984

$8,591,439$

1,000

12,672

$2,279,451$

$28,885,284$

$2,958,436$

$38,174,905$

97,917

0.469

7.00

$13.1 \%$ 


\section{ECONOMIC ANALYSIS}

\section{Input Values}

System load (kWh/y)

Diesel energy $(\mathrm{kWh} / \mathrm{y})$

Wind energy $(\mathrm{kWh} / \mathrm{y})$

Diesel fuel usage, no wind (I/yr) $\mathrm{FL}$

Diesel fuel usage, with wind (I/yr) $F$

Diesel fuel cost (\$/I)

Diesel ops cost, variable $(\$ / k W h)$ OV

Diesel ops cost, fixed $(\$ / y)$

Wind ICC (\$)

Wind O\&M cost $(\$ / \mathrm{kWh})$

System life, (yrs)

General inflation

Fuel inflation

Discount rate

Interest

Term of loan, (yrs)
Site: $\quad$ San Clemente Island, CA, $5.0 \mathrm{~m} / \mathrm{s}$ avg

Turbine: 225 kW, Commercial

\section{Quantity:}

\section{2}

$\begin{array}{lr}\text { SL } & 7,618,476 \\ & 7,042,272 \\ \text { FL } & 576,204 \\ \text { FL } & 2,688,873 \\ \text { FC } & 2,539,421 \\ \text { OV } & 0.264 \\ \text { OF } & 0.154 \\ \text { WC } & 1,173,245 \\ \text { WO } & 635,510 \\ \text { L } & 0.01 \\ \text { i } & 20 \\ \text { e } & 2.0 \% \\ \text { d } & 2.0 \% \\ \text { b } & 6.9 \% \\ \text { N } & 10.0 \% \\ \text { W } & 10\end{array}$

\section{Economic Factors}

Present worth factor of fuel costs, PWFF, $a=(1+e) /(1+d)$ Present worth factor of O\&M costs, PWFO, $a=(1+i) /(1+d)$

Present worth factor of interest payments, $P W F P, a=1 /(1+b)$

\begin{tabular}{|c|c|c|}
\hline$\underline{\text { a variable }}$ & $\underline{\mathrm{n} \text { variable }}$ & $Y(a, n)$ \\
\hline 0.95416277 & 20 & 12.67203 \\
\hline 0.95416277 & 20 & 12.67203 \\
\hline 0.935453 & 10 & 7.056 \\
\hline
\end{tabular}

\section{$\underline{\text { a variable }} \underline{\mathrm{n} \text { variable }} \quad \underline{\mathrm{X}(\mathrm{a}, \mathrm{n})}$}

Capital recovery factor for system income, CRFI, $a=1 /(1+d)$

Capital recovery factor for interest payments, CRFP, $a=1 /(1+b)$

$\begin{array}{lll}0.9354537 & 20 & 0.09366054 \\ 0.90909091 & 10 & 0.16274539\end{array}$

$10 \quad 0.16274539$

\section{Calculated Values for Both Systems}

\section{Capital cost}

Initial payment on system

Loan

Annual payment

NPV of annual payment

Fuel cost per annum

NPV of fuel costs

Overhaul cost per annum

NPV of overhaul costs

O\&M costs per annum

NPV of O\&M costs

Total annual costs

Total system NPV, TNPV

Annual savings

Levelized cost of energy, COE

Payback period, years

Internal rate of return, IRR, $(x)$

\begin{abstract}
$\mathrm{C}=\mathrm{ICC}+\mathrm{BOS}$
Ad

$\mathrm{Al}=\mathrm{C}-\mathrm{Ad}$

$A p=A l * C R F P$

Apnpv $=$ Ap*PWFP

$A f=F L$ * FC

Afnpv $=A f *$ PWFF

Ao

Aonpv $=$ Ao * PWFO

Am

$A m n p v=A m * P W F O$

$A t=A p+A f+A o+A m$

$=A d+\operatorname{sum}(N P V s)$

Sv $=$ dsl At - hbd At

$=\mathrm{TNPV}^{*} \mathrm{CRFI} / \mathrm{SL}$
\end{abstract}

$\begin{array}{rr}\begin{array}{c}\text { Diesel } \\ \text { Only }\end{array} & \begin{array}{r}\text { Hybrid System } \\ \text { Diesel Part }\end{array} \\ 0 & 0 \\ 0 & 0 \\ 0 & 0 \\ 0 & 0 \\ 0 & 0 \\ 709,863 & 670,407 \\ 8,995,402 & 8,495,420 \\ 0 & 0 \\ 0 & 0 \\ 2,346,490 & 2,257,755 \\ 29,734,802 & 28,610,344 \\ 3,056,353 & 2,928,162 \\ 38,730,204 & 37,105,764 \\ 0.476 & 0.493\end{array}$
Hybrid System
Wind Part
$1,271,020$
$1,271,020$

Hybrid System

Total

$1,271,020$

$1,271,020$

0

0

670,407

$8,495,420$

2,000

25,344

$2,263,517$

$28,683,361$

$2,935,924$

$38,475,145$

120,429

0.473

10.55

0.000

$(\mathrm{NPV}=$ net present value $; \mathrm{ICC}=$ initial capitol cost; $\mathrm{BOS}=$ balance of station $=26 \% \mathrm{ICC} ;$ O\&M = operations and maintenance $)$ 


\section{ECONOMIC ANALYSIS}

\section{Input Values}

System load (kWh/y)

Diesel energy $(\mathrm{kWh} / \mathrm{y})$

Wind energy $(\mathrm{kWh} / \mathrm{y})$

Diesel fuel usage, no wind (I/yr) $\mathrm{FL}$

Diesel fuel usage, with wind (I/yr) $F$

Diesel fuel cost (\$/I)

Diesel ops cost, variable $(\$ / \mathrm{kWh})$ OV

Diesel ops cost, fixed (\$/y)

Wind ICC (\$)

Wind O\&M cost $(\$ / \mathrm{kWh})$

System life, (yrs)

General inflation

Fuel inflation

Discount rate

Interest

Term of loan, (yrs)
Site: $\quad$ San Clemente Island, CA, $6.1 \mathrm{~m} / \mathrm{s}$ avg

Turbine: 225 kW, Commercial

\section{Quantity:}

\section{2}

$\begin{array}{lr}\text { SL } & 7,618,476 \\ & 6,687,381 \\ \text { FL } & 931,095 \\ \text { FL } & 2,688,873 \\ \text { FC } & 2,447,371 \\ \text { OV } & 0.264 \\ \text { OF } & 0.154 \\ \text { WC } & 1,173,245 \\ \text { WO } & 635,510 \\ \text { L } & 0.01 \\ \text { i } & 20 \\ \text { e } & 2.0 \% \\ \text { d } & 2.0 \% \\ \text { b } & 6.9 \% \\ \text { N } & 10.0 \% \\ \text { W } & 10\end{array}$

\section{Economic Factors}

Present worth factor of fuel costs, PWFF, $a=(1+e) /(1+d)$ Present worth factor of O\&M costs, PWFO, $a=(1+i) /(1+d)$

Present worth factor of interest payments, $P W F P, a=1 /(1+b)$

\begin{tabular}{|c|c|c|}
\hline$\underline{\text { a variable }}$ & $\underline{\mathrm{n} \text { variable }}$ & $Y(a, n)$ \\
\hline 0.95416277 & 20 & 12.67203 \\
\hline 0.95416277 & 20 & 12.67203 \\
\hline 0.935453 & 10 & 7.056 \\
\hline
\end{tabular}

\section{$\underline{\text { a variable }} \underline{\mathrm{n} \text { variable }} \underline{\mathrm{X}(\mathrm{a}, \mathrm{n})}$}

Capital recovery factor for system income, CRFI, $a=1 /(1+d)$

Capital recovery factor for interest payments, CRFP, $a=1 /(1+b)$

$\begin{array}{lll}0.9354537 & 20 & 0.09366054 \\ 0.90909091 & 10 & 0.16274539\end{array}$

$10 \quad 0.16274539$

\section{Calculated Values for Both Systems}

\section{Capital cost}

Initial payment on system

Loan

Annual payment

Fuel cost per annum

NPV of fuel costs

Overhaul cost per annum

NPV of overhaul costs

O\&M costs per annum

NPV of O\&M costs

Total annual costs

Total system NPV, TNPV

Annual savings

Levelized cost of energy, COE

Payback period, years

Internal rate of return, IRR, $(x)$
NPV of annual payment

\begin{abstract}
$\mathrm{C}=\mathrm{ICC}+\mathrm{BOS}$
Ad

$\mathrm{Al}=\mathrm{C}-\mathrm{Ad}$

$A p=A l * C R F P$

Apnpv $=$ Ap*PWFP

$\mathrm{Af}=\mathrm{FL}{ }^{*} \mathrm{FC}$

Afnpv $=A f *$ PWFF

Ao

Aonpv $=$ Ao * PWFO

Am

$A m n p v=A m * P W F O$

$A t=A p+A f+A o+A m$

$=A d+\operatorname{sum}(N P V s)$

Sv $=$ dsl At - hbd At

$=\mathrm{TNPV}^{*} \mathrm{CRFI} / \mathrm{SL}$
\end{abstract}

\section{Diesel}

Only

$\left[(1+x)^{\wedge} L-1\right] /\left[x^{*}(1+x)^{\wedge} L\right]-P=$

Hybrid System
Diesel Part
0
0
0
0
0
646,106
$8,187,475$
0
0
$2,203,102$
$27,917,777$
$2,849,208$
$36,105,252$
0.506

0.000

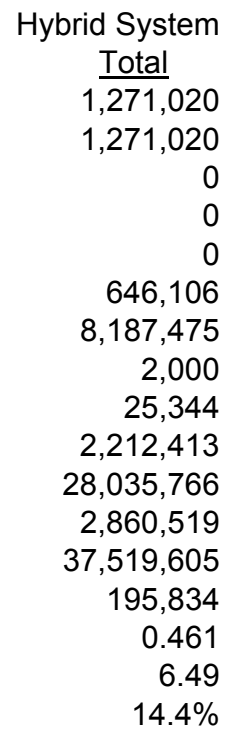

$(\mathrm{NPV}=$ net present value; $\mathrm{ICC}=$ initial capitol cost; $\mathrm{BOS}=$ balance of station $=26 \%$ ICC; O\&M = operations and maintenance $)$ 


\section{ECONOMIC ANALYSIS}

\section{Input Values}

System load (kWh/y)

Diesel energy $(\mathrm{kWh} / \mathrm{y})$

Wind energy $(\mathrm{kWh} / \mathrm{y})$

Diesel fuel usage, no wind (I/yr) $\mathrm{FL}$

Diesel fuel usage, with wind (I/yr) $F$

Diesel fuel cost (\$/I)

Diesel ops cost, variable $(\$ / k W h)$ OV

Diesel ops cost, fixed $(\$ / y)$

Wind ICC (\$)

Wind O\&M cost $(\$ / \mathrm{kWh})$

System life, (yrs)

General inflation

Fuel inflation

Discount rate

Interest

Term of loan, (yrs)
Site: $\quad$ San Clemente Island, CA, 7.2 m/s avg

Turbine: 225 kW, Commercial

\section{Quantity:}

\section{2}

$\begin{array}{lr}\text { SL } & 7,618,476 \\ & 6,323,127 \\ \text { FL } & 1,295,349 \\ \text { FL } & 2,688,873 \\ \text { FC } & 2,352,892 \\ \text { OV } & 0.264 \\ \text { OF } & 0.154 \\ \text { WC } & 1,173,245 \\ \text { WO } & 635,510 \\ \text { L } & 0.01 \\ \text { i } & 20 \\ \text { e } & 2.0 \% \\ \text { d } & 2.0 \% \\ \text { b } & 6.9 \% \\ \text { N } & 10.0 \% \\ \text { W } & 10\end{array}$

\section{Economic Factors}

Present worth factor of fuel costs, PWFF, $a=(1+e) /(1+d)$ Present worth factor of O\&M costs, PWFO, $a=(1+i) /(1+d)$

Present worth factor of interest payments, $P W F P, a=1 /(1+b)$

\begin{tabular}{|c|c|c|}
\hline$\underline{\text { a variable }}$ & $\underline{\mathrm{n} \text { variable }}$ & $Y(a, n)$ \\
\hline 0.95416277 & 20 & 12.67203 \\
\hline 0.95416277 & 20 & 12.67203 \\
\hline 0.935453 & 10 & 7.056 \\
\hline
\end{tabular}

\section{$\underline{\text { a variable }} \underline{\mathrm{n} \text { variable }} \quad \underline{\mathrm{X}(\mathrm{a}, \mathrm{n})}$}

Capital recovery factor for system income, CRFI, $a=1 /(1+d)$

Capital recovery factor for interest payments, CRFP, $a=1 /(1+b)$

$\begin{array}{lll}0.9354537 & 20 & 0.09366054 \\ 0.90909091 & 10 & 0.16274539\end{array}$

$10 \quad 0.16274539$

\section{Calculated Values for Both Systems}

\section{Capital cost}

Initial payment on system

Loan

Annual payment

NPV of annual payment

Fuel cost per annum

NPV of fuel costs

Overhaul cost per annum

NPV of overhaul costs

O\&M costs per annum

NPV of O\&M costs

Total annual costs

Total system NPV, TNPV

Annual savings

Levelized cost of energy, COE

Payback period, years

Internal rate of return, IRR, $(x)$

\begin{abstract}
$\mathrm{C}=\mathrm{ICC}+\mathrm{BOS}$
Ad

$\mathrm{Al}=\mathrm{C}-\mathrm{Ad}$

$A p=A l * C R F P$

Apnpv $=$ Ap*PWFP

$\mathrm{Af}=\mathrm{FL}{ }^{*} \mathrm{FC}$

Afnpv $=A f *$ PWFF

Ao

Aonpv $=$ Ao * PWFO

Am

$A m n p v=A m * P W F O$

$A t=A p+A f+A o+A m$

$=A d+\operatorname{sum}(N P V s)$

Sv $=$ dsl At - hbd At

$=\mathrm{TNPV}^{*} \mathrm{CRFI} / \mathrm{SL}$
\end{abstract}

$\begin{array}{rr}\begin{array}{r}\text { Diesel } \\ \text { Only }\end{array} & \begin{array}{r}\text { Hybrid System } \\ \text { Diesel Part }\end{array} \\ 0 & 0 \\ 0 & 0 \\ 0 & 0 \\ 0 & 0 \\ 0 & 0 \\ 709,863 & 621,164 \\ 8,995,402 & 7,871,405 \\ 0 & 0 \\ 0 & 0 \\ 2,346,490 & 2,147,007 \\ 29,734,802 & 27,206,938 \\ 3,056,353 & 2,768,170 \\ 38,730,204 & 35,078,343\end{array}$

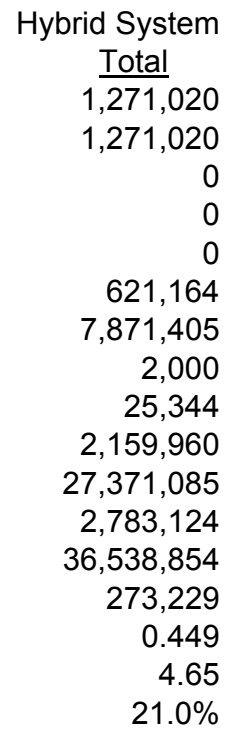

$(\mathrm{NPV}=$ net present value $; \quad I C C=$ initial capitol cost; $B O S=$ balance of station $=26 \%$ ICC; O\&M = operations and maintenance $)$ 


\section{ECONOMIC ANALYSIS}

\section{Input Values}

System load (kWh/y)

Diesel energy $(\mathrm{kWh} / \mathrm{y})$

Wind energy $(\mathrm{kWh} / \mathrm{y})$

Diesel fuel usage, no wind $(\mathrm{I} / \mathrm{yr}) \quad \mathrm{FL} \quad 2,688,873$

Diesel fuel usage, with wind (I/yr) F

Diesel fuel cost (\$/I)

Diesel ops cost, variable $(\$ / k W h)$ OV

Diesel ops cost, fixed (\$/y)

Wind ICC (\$)

Wind O\&M cost $(\$ / \mathrm{kWh})$

System life, (yrs)

General inflation

Fuel inflation

Discount rate

Interest

Term of loan, (yrs)

\section{Quantity:}

\section{3}

$\begin{array}{lr}\text { SL } & 7,618,476 \\ & 6,232,205 \\ \text { FL } & 1,386,271 \\ \text { FL } & 2,688,873 \\ \text { FC } & 2,329,309 \\ \text { OV } & 0.264 \\ \text { OF } & 0.154 \\ \text { WC } & 1,173,245 \\ \text { WO } & 610,510 \\ \text { L } & 0.01 \\ \text { i } & 20 \\ \text { e } & 2.0 \% \\ \text { d } & 2.0 \% \\ \text { b } & 6.9 \% \\ \text { N } & 10.0 \% \\ \end{array}$

Site: $\quad$ San Clemente Island, CA, $6.1 \mathrm{~m} / \mathrm{s}$ avg

Turbine: 225 kW, Commercial

\section{Economic Factors}

Present worth factor of fuel costs, PWFF, $a=(1+e) /(1+d)$ Present worth factor of O\&M costs, PWFO, $a=(1+i) /(1+d)$

Present worth factor of interest payments, $P W F P, a=1 /(1+b)$

\begin{tabular}{|c|c|c|}
\hline$\underline{\text { a variable }}$ & $\underline{\mathrm{n} \text { variable }}$ & $Y(a, n)$ \\
\hline 0.95416277 & 20 & 12.67203 \\
\hline 0.95416277 & 20 & 12.67203 \\
\hline 0.9354537 & 10 & 7.05616 \\
\hline
\end{tabular}

\section{$\underline{\text { a variable }} \underline{\mathrm{n} \text { variable } \quad \underline{X(a, n)}}$}

Capital recovery factor for system income, CRFI, $a=1 /(1+d)$

Capital recovery factor for interest payments, CRFP, $a=1 /(1+b)$

$\begin{array}{lll}0.9354537 & 20 & 0.09366054 \\ 0.90909091 & 10 & 0.16274539\end{array}$

Hybrid System

Wind Part

$1,831,530$

$1,831,530$

Diesel Part

Only

$\mathrm{Ad}$

$\mathrm{Al}=\mathrm{C}-\mathrm{Ad}$

$A p=A l * C R F P$

Apnpv $=$ Ap*PWFP

Af $=F L{ }^{*} F C$

Afnpv $=A f * P W F F$

Ao

Aonpv $=$ Ao * PWFO

Am

$A m n p v=A m * P W F O$

$A t=A p+A f+A o+A m$

$=A d+\operatorname{sum}(N P V s)$

Sv $=$ dsl At - hbd At

$=\mathrm{TNPV}^{*} \mathrm{CRFI} / \mathrm{SL}$
0

0

0

0

0

709,863

$8,995,402$

0

$2,346,490$

$29,734,802$

$3,056,353$

$38,730,204$

0.476

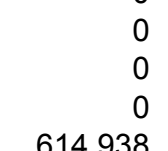

$7,792,510$
0

$2,133,005$

$27,029,503$

$2,747,942$

$34,822,014$

0.523

0.000
Hybrid System

Total

$1,831,530$

$1,831,530$

0

0

614,938

$7,792,510$

3,000

38,016

$2,146,867$

$27,205,172$

$2,764,805$

$36,867,229$

291,548

0.453

6.28

$14.9 \%$
0.138

Internal rate of return, $I R R,(x) \quad\left[(1+x)^{\wedge} L-1\right] /\left[x^{*}(1+x)^{\wedge} L\right]-P=$

$(\mathrm{NPV}=$ net present value; $\mathrm{ICC}=$ initial capitol cost; $\mathrm{BOS}=$ balance of station $=26 \% \mathrm{ICC} ; \mathrm{O} \& \mathrm{M}=$ operations and maintenance $)$ 


\section{ECONOMIC ANALYSIS}

\section{Input Values}

System load (kWh/y)

Diesel energy $(\mathrm{kWh} / \mathrm{y})$

Wind energy $(\mathrm{kWh} / \mathrm{y})$

Diesel fuel usage, no wind (I/yr) $\mathrm{FL}$

Diesel fuel usage, with wind (I/yr) $F$

Diesel fuel cost (\$/I)

Diesel ops cost, variable $(\$ / k W h)$ OV

Diesel ops cost, fixed $(\$ / y)$

Wind ICC (\$)

Wind O\&M cost $(\$ / \mathrm{kWh})$

System life, (yrs)

General inflation

Fuel inflation

Discount rate

Interest

Term of loan, (yrs)

\section{Calculated Values for Both Systems}

\section{Capital cost}

Initial payment on system

Loan

Annual payment

NPV of annual payment

Fuel cost per annum

NPV of fuel costs

NPV of overhaul costs

O\&M costs per annum

NPV of O\&M costs

Total annual costs

Total system NPV, TNPV

Annual savings

Levelized cost of energy, COE

Internal rate of return, IRR, $(x)$

Ad

Ao

Am
Site: $\quad$ San Clemente Island, CA, $6.1 \mathrm{~m} / \mathrm{s}$ avg

Turbine:

Quantity:

225 kW, Commercia

$\begin{array}{lr}\text { SL } & 7,618,476 \\ & 5,856,374 \\ \text { FL } & 1,762,102 \\ \text { FL } & 2,688,873 \\ \text { FC } & 2,231,828 \\ \text { OV } & 0.264 \\ \text { OF } & 0.154 \\ \text { WC } & 1,173,245 \\ \text { WO } & 585,510 \\ \text { L } & 0.01 \\ \text { i } & 20 \\ \text { e } & 2.0 \% \\ \text { d } & 2.0 \% \\ \text { b } & 6.9 \% \\ \text { N } & 10.0 \% \\ \end{array}$

\section{Economic Factors}

Present worth factor of fuel costs, PWFF, $a=(1+e) /(1+d)$ Present worth factor of O\&M costs, PWFO, $a=(1+i) /(1+d)$

Present worth factor of interes payments, $P W F P, a=1 /(1+b)$

\begin{tabular}{|c|c|c|}
\hline variable & $\underline{\mathrm{n} \text { variable }}$ & $\underline{Y(a, n)}$ \\
\hline 0.95416 & 20 & 12.67203 \\
\hline 0.95416 & 20 & 12.67203 \\
\hline 0.93545 & 10 & 7.05616 \\
\hline
\end{tabular}

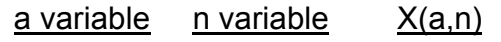

Capital recovery factor for system income, CRFI, $a=1 /(1+d)$

Capital recovery factor for interest payments, CRFP, $a=1 /(1+b)$

$\begin{array}{lll}0.93545 & 20 & 0.09366 \\ 0.90909 & 10 & 0.16275\end{array}$

Hybrid System Hybrid System Wind Part

$2,342,040$

$2,342,040$

$2,342,040$

$2,342,040$

Apnpv $=$ Ap*PWFP

Hybrid System
Diesel Part

Only

$\mathrm{Sv}=\mathrm{ds}$ At $-\mathrm{hbd}$ At

0
Overhaul cost per annum

Payback period, years

$\mathrm{Al}=\mathrm{C}-\mathrm{Ad}$

$A p=A l * C R F P$

$A f=F L{ }^{*} F C$

Afnpv $=A f * P W F F$

Aonpv $=$ Ao * PWFO

Amnpv $=A m^{*} P W F O$

$A t=A p+A f+A o+A m$

$=A d+\operatorname{sum}(N P V s)$

$=\mathrm{TNPV}{ }^{*} \mathrm{CRFI} / \mathrm{SL}$

0

0

0

0
0983

$8,995,402$

0

$2,346,490$

$29,734,802$

$3,056,353$

$38,730,204$

0.476

$\mathrm{P}=\mathrm{C} / \mathrm{SV}$

$\left[(1+x)^{\wedge} L-1\right] /\left[x^{*}(1+x)^{\wedge} L\right]-P=$

0
0
589,203
$7,466,395$
0
0
$2,075,127$
$26,296,072$
$2,664,329$
$33,762,467$

0.540

0.000

$$
\begin{array}{r}
0 \\
0 \\
0 \\
589,203 \\
7,466,395 \\
4,000 \\
50,688 \\
2,092,748 \\
26,519,366 \\
2,685,950 \\
36,378,490 \\
370,403 \\
0.447 \\
6.32 \\
14.8 \%
\end{array}
$$

$(N P V=$ net present value; $I C C=$ initial capitol cost; $B O S=$ balance of station $=26 \%$ ICC $; \quad O \& M=$ operations and maintenance $)$ 


\section{$\underline{\text { Input Values }}$}

$\begin{array}{llr}\text { System load }(\mathrm{kWh} / \mathrm{y}) & \mathrm{SL} & 7,618,476 \\ \text { Diesel energy }(\mathrm{kWh} / \mathrm{y}) & & 6,687,381 \\ \text { Wind energy }(\mathrm{kWh} / \mathrm{y}) & & 931,095 \\ \text { Diesel fuel usage, no wind }(\mathrm{I} / \mathrm{yr}) & \mathrm{FL} & 2,688,873 \\ \text { Diesel fuel usage, with wind (I/yr) } & \mathrm{FL} & 2,447,371 \\ \text { Diesel fuel cost }(\$ / \mathrm{l}) & \mathrm{FC} & 0.264 \\ \text { Diesel ops cost, variable (\$/kWh) } & \text { OV } & 0.154 \\ \text { Diesel ops cost, fixed }(\$ / \mathrm{y}) & \text { OF } & 1,173,245 \\ \text { Wind ICC }(\$) & \text { WC } & 354,600 \\ \text { Wind O\&M cost }(\$ / \mathrm{kWh}) & \text { WO } & 0.01 \\ \text { System life, }(\mathrm{yrs}) & \mathrm{L} & 20 \\ \text { General inflation } & \mathrm{i} & 2.0 \% \\ \text { Fuel inflation } & \mathrm{e} & 2.0 \% \\ \text { Discount rate } & \mathrm{d} & 6.9 \% \\ \text { Interest } & \mathrm{b} & 10.0 \% \\ \text { Term of loan, }(\mathrm{yrs}) & \mathrm{N} & 10\end{array}$

\section{Calculated Values for Both Systems}

\section{Capital cost}

Initial payment on system

Loan

Annual payment

NPV of annual payment

Fuel cost per annum

NPV of fuel costs

Overhaul cost per annum

NPV of overhaul costs

O\&M costs per annum

NPV of O\&M costs

Total annual costs

Total system NPV, TNPV

Annual savings

Levelized cost of energy, COE

Payback period, years

Internal rate of return, IRR, (x)

\section{Economic Factors}

Present worth factor of fuel costs, PWFF, $a=(1+e) /(1+d)$ Present worth factor of O\&M costs, PWFO, $a=(1+i) /(1+d)$ Present worth factor of interest payments, PWFP, $a=1 /(1+b)$

\begin{tabular}{|c|c|c|}
\hline$\underline{\text { a variable }}$ & $\underline{\mathrm{n} \text { variable }}$ & $\underline{Y(a, n)}$ \\
\hline 0.95416277 & 20 & 12.67203 \\
\hline 0.95416277 & 20 & 12.67203 \\
\hline 0.9354537 & 10 & \\
\hline
\end{tabular}

Capital recovery factor for system income, CRFI, $a=1 /(1+d)$

Capital recovery factor for interest payments, CRFP, $a=1 /(1+b)$

$\begin{array}{lrrr}\text { a variable } & \underline{n \text { variable }} & \underline{X(a, n)} \\ 0.9354537 & 20 & 0.09366054 \\ 0.90909091 & 10 & 0.16274539\end{array}$

Hybrid System Hybrid System Wind Part Total

\begin{tabular}{|c|c|c|c|c|}
\hline$C=I C C+B O S$ & 1 & 0 & 709,200 & 709,200 \\
\hline $\mathrm{Ad}$ & 0 & 0 & 709,200 & 709,200 \\
\hline $\mathrm{Al}=\mathrm{C}-\mathrm{Ad}$ & 0 & 0 & 0 & 0 \\
\hline$A p=A l * C R F P$ & 0 & 0 & 0 & 0 \\
\hline$A p n p v=A p^{*} P W F P$ & 0 & 0 & 0 & 0 \\
\hline $\mathrm{Af}=\mathrm{FL}{ }^{*} \mathrm{FC}$ & 709,863 & 646,106 & 0 & 646,106 \\
\hline Afnpv $=A f * P W F F$ & $8,995,402$ & $8,187,475$ & 0 & $8,187,475$ \\
\hline Ao & 0 & 0 & 2,000 & 2,000 \\
\hline Aonpv $=$ Ao * PWFO & 0 & 0 & 25,344 & 25,344 \\
\hline $\mathrm{Am}$ & $2,346,490$ & $2,203,102$ & 9,311 & $2,212,413$ \\
\hline Amnpv $=A m * P W F O$ & $29,734,802$ & $27,917,777$ & 117,989 & $28,035,766$ \\
\hline$A t=A p+A f+A o+A m$ & $3,056,353$ & $2,849,208$ & 11,311 & $2,860,519$ \\
\hline$=\mathrm{Ad}+\mathrm{sum}(\mathrm{NPVs})$ & $38,730,204$ & $36,105,252$ & 852,533 & $36,957,785$ \\
\hline$S v=d s l A t-h b d$ At & & & & 195,834 \\
\hline$=\mathrm{TNPV}{ }^{*} \mathrm{CRFI} / \mathrm{SL}$ & 0.476 & 0.506 & 0.086 & $\begin{array}{r}0.454 \\
3.62\end{array}$ \\
\hline$\left[(1+x)^{\wedge} L-1\right] /\left[x^{*}(1+x)^{\wedge} L\right]$ & & & & $27.4 \%$ \\
\hline
\end{tabular}

(NPV = net present value; ICC = initial capitol cost; BOS = balance of station $=26 \%$ ICC; O\&M = operations and maintenance $)$ 


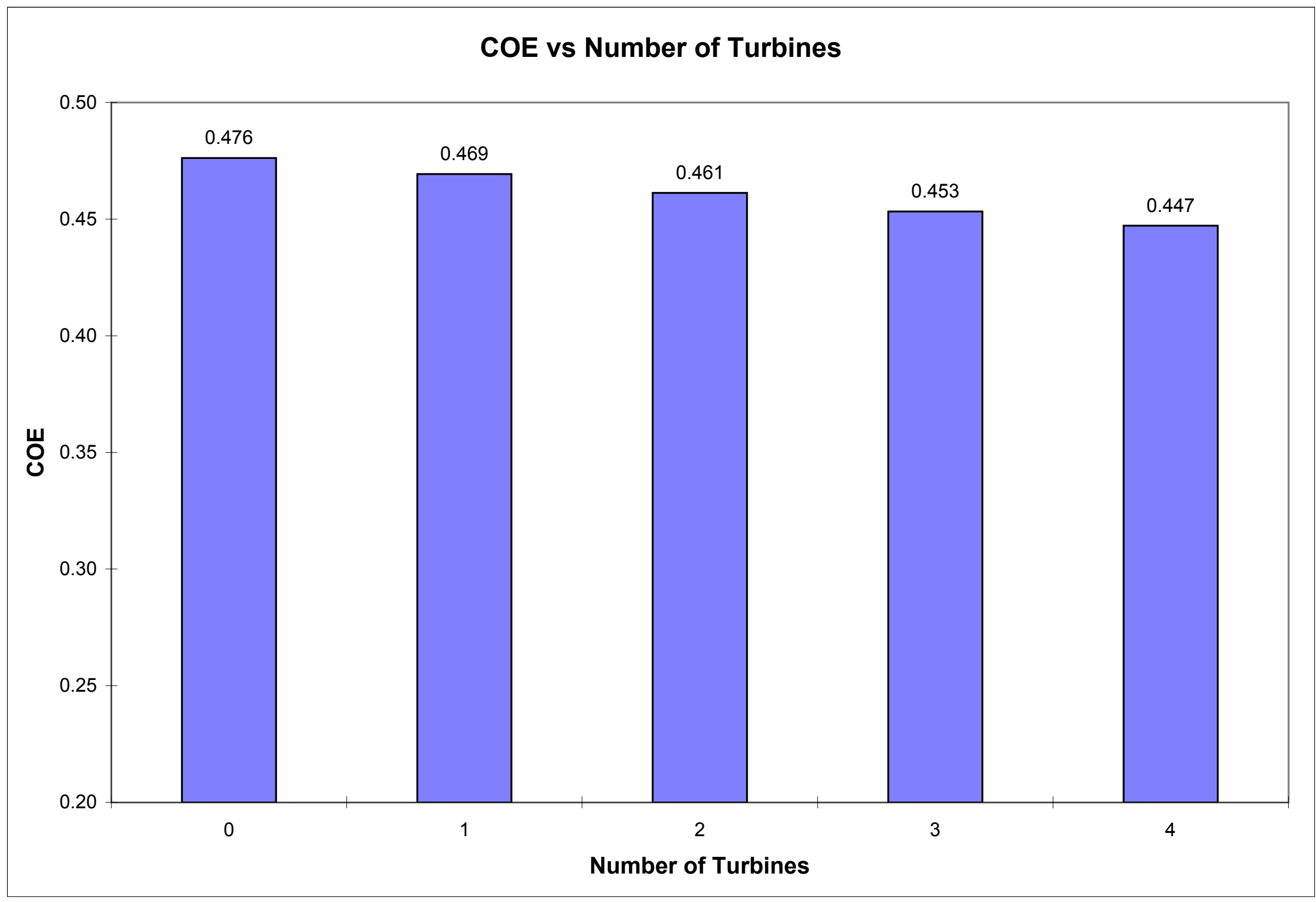

Page 1 


\section{APPENDIX B: \\ SCI 1998-1999 Power Plant Status and Production Reports}

SCI 1998-1999 power plant status and production reports displaying the measured wind turbine and diesel electrical energy production contributing to the total San Clemente Island electrical

demand. These spreadsheets indicate fuel usage, individual diesel operation and production, and individual wind turbine operation and production. 


\section{February 1998 - January 1999}

\begin{tabular}{|c|c|c|c|c|c|c|c|c|c|c|c|c|c|c|c|c|c|c|c|}
\hline & & & & & & & SCl & Power Plc & lant Proo & Iuction $R e$ & port & & & & & & & & \\
\hline & & Fuel \& & Oil Used & & & & & & Diesel G & enerators & & & Wind Tu & urbines & & & al Diesel & rot. $W$ & Grid Load \\
\hline & & & Tota & & Daily $P$ & Demand & Avg & $500 \mathrm{KW}$ & $500 \mathrm{KW}$ & $1.2 \mathrm{MW}$ & $750 \mathrm{KW}$ & 225 & $K W W T-1$ & 225 & $W W T-2$ & & $K W H$ & $K W H$ & Tot. KWH \\
\hline Date & Fuel & Lube & Fuel & Lube & Time & Load & PF & $D E-1$ & $D E-2$ & $D E-3$ & $D E-4$ & Daily & CUM & Daily & CUM & Daily & CUM & Daily & Daily \\
\hline & & & & & & & & & & & & & & & & & & & 0 \\
\hline Jan-98 & & & & & & & & & & & & & & & & & & & 0 \\
\hline Feb-98 & & & 42580 & 496.9 & & & & & & & & & 38122 & & 57757 & & 510068 & & 605947 \\
\hline \begin{tabular}{|l|} 
Mar-98 \\
\end{tabular} & & & 45250 & 387.4 & & & & & & & & & 37839 & & 44341 & & 520800 & & 602980 \\
\hline Apr-98 & & & 43710 & 309.9 & & & & & & & & & 46161 & & 44819 & & 531300 & & 622280 \\
\hline May-98 & & & 40940 & 287 & & & & & & & & & 53621 & & 52120 & & 496300 & & 602041 \\
\hline Jun-98 & & & 41780 & 282 & & & & & & & & & 49255 & & 46972 & & 495600 & & 591827 \\
\hline Jul-98 & & & 45251 & 289.5 & & & & & & & & & 31481 & & 29385 & & 542150 & & 603016 \\
\hline Aug-98 & & & 48700 & 285 & & & & & & & & & 23649 & & 21977 & & 584850 & & 630476 \\
\hline Sep-98 & & & 45736 & 585 & & & & & & & & & 23594 & & 22423 & & 555778 & & 601795 \\
\hline Oct-98 & & & 48441 & 360.5 & & & & & & & & & 20356 & & 19511 & & 563150 & & 603017 \\
\hline \begin{tabular}{|l|} 
Nov-98 \\
\end{tabular} & & & 51180 & 528 & & & & & & & & & 32155 & & 27362 & & 607600 & & 667117 \\
\hline Dec-98 & & & 55380 & 373.7 & & & & & & & & & 29516 & & 33522 & & 645400 & & 708438 \\
\hline Jan-99 & & & 54680 & 453.6 & & & & & & & & & 28982 & & 30333 & & 634550 & & 693865 \\
\hline Totals & & & 563628 & 4638.5 & & & & & & & & & 414731 & & 430522 & & 6687546 & & 7532799 \\
\hline & & & & & & & & & & & & & & & & & & & \\
\hline MONTH & TAL K & H PR & JCED & & & & & & & & & & & & & & & & 7532799 \\
\hline DIESEL & PROD & CED $P$ & GAL OF & FUEL & & & & & & & & & & & & & & & 11.87 \\
\hline \% WIND & BINE K & H PR & JCED TO & TOTAL & GRID & & & & & & & & & & & & & & $11.22 \%$ \\
\hline FUEL S & S BY & IND T & BINE OP & ERATIO & NS IN & GALLON & (AVC & IDED GA & ALLONS & USED) & & & & & & & & & 71238 \\
\hline & & & & & & WT\#1 & & WT\#2 & & Total & & & Total & & & & & & \\
\hline & & & & & & & & & & WTs & & & Diesel & & & & & & \\
\hline & & & & & & 38122 & & 57757 & & 95879 & & & 510068 & & & & & & \\
\hline & & & & & & 37839 & & 44341 & & 82180 & & & 520800 & & & & & & \\
\hline & & & & & & 46161 & & 44819 & & 90980 & & & 531300 & & & & & & \\
\hline & & & & & & 53621 & & 52120 & & 105741 & & & 496300 & & & & & & \\
\hline & & & & & & 49255 & & 46972 & & 96227 & & & 495600 & & & & & & \\
\hline & & & & & & 31481 & & 29385 & & 60866 & & & 542150 & & & & & & \\
\hline & & & & & & 23649 & & 21977 & & 45626 & & & 584850 & & & & & & \\
\hline & & & & & & 23594 & & 22423 & & 46017 & & & 555778 & & & & & & \\
\hline & & & & & & 20356 & & 19511 & & 39867 & & & 563150 & & & & & & \\
\hline & & & & & & 32155 & & 27362 & & 59517 & & & 607600 & & & & & & \\
\hline & & & & & & 29516 & & 33522 & & 63038 & & & 645400 & & & & & & \\
\hline & & & & & & 28982 & & 30333 & & 59315 & & & 634550 & & & & & & \\
\hline & & & & & & & & & & & & & & & & & & & \\
\hline
\end{tabular}




\section{San Clemente Island, California}

\section{Total Electrical Production}

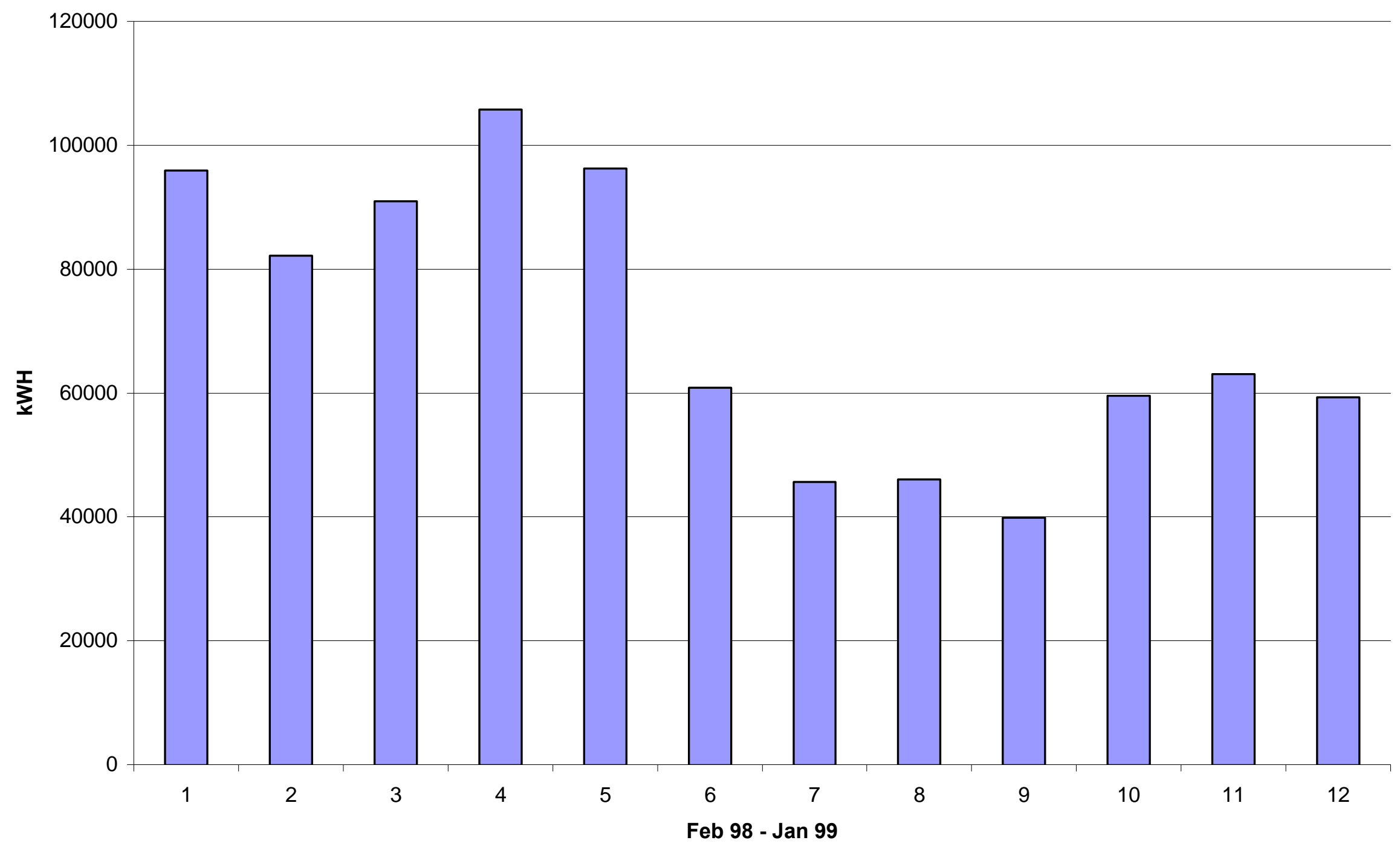




\section{San Clemente Island, CA}

Total Production Levels

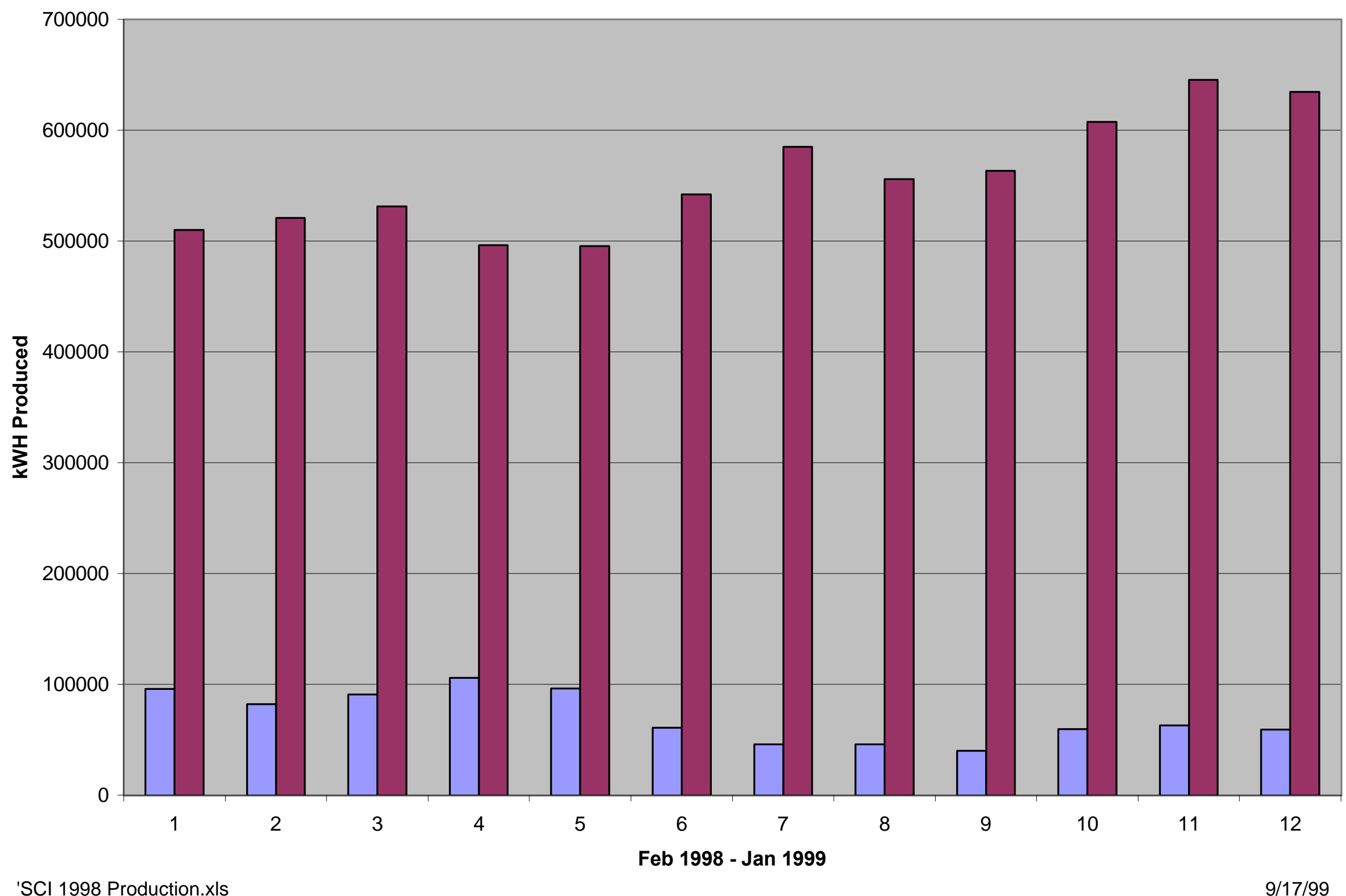


February 1998

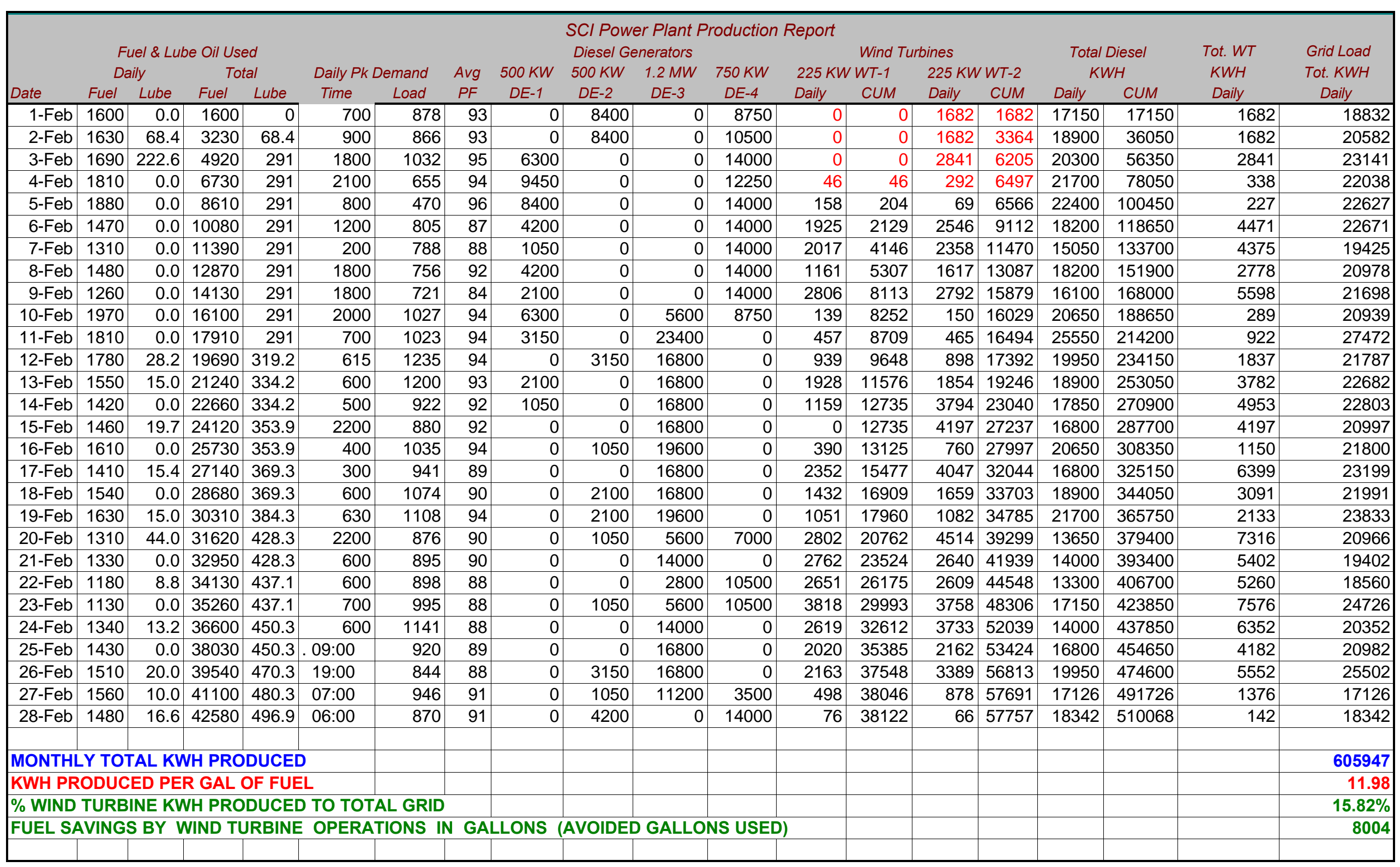


MARCH 1998

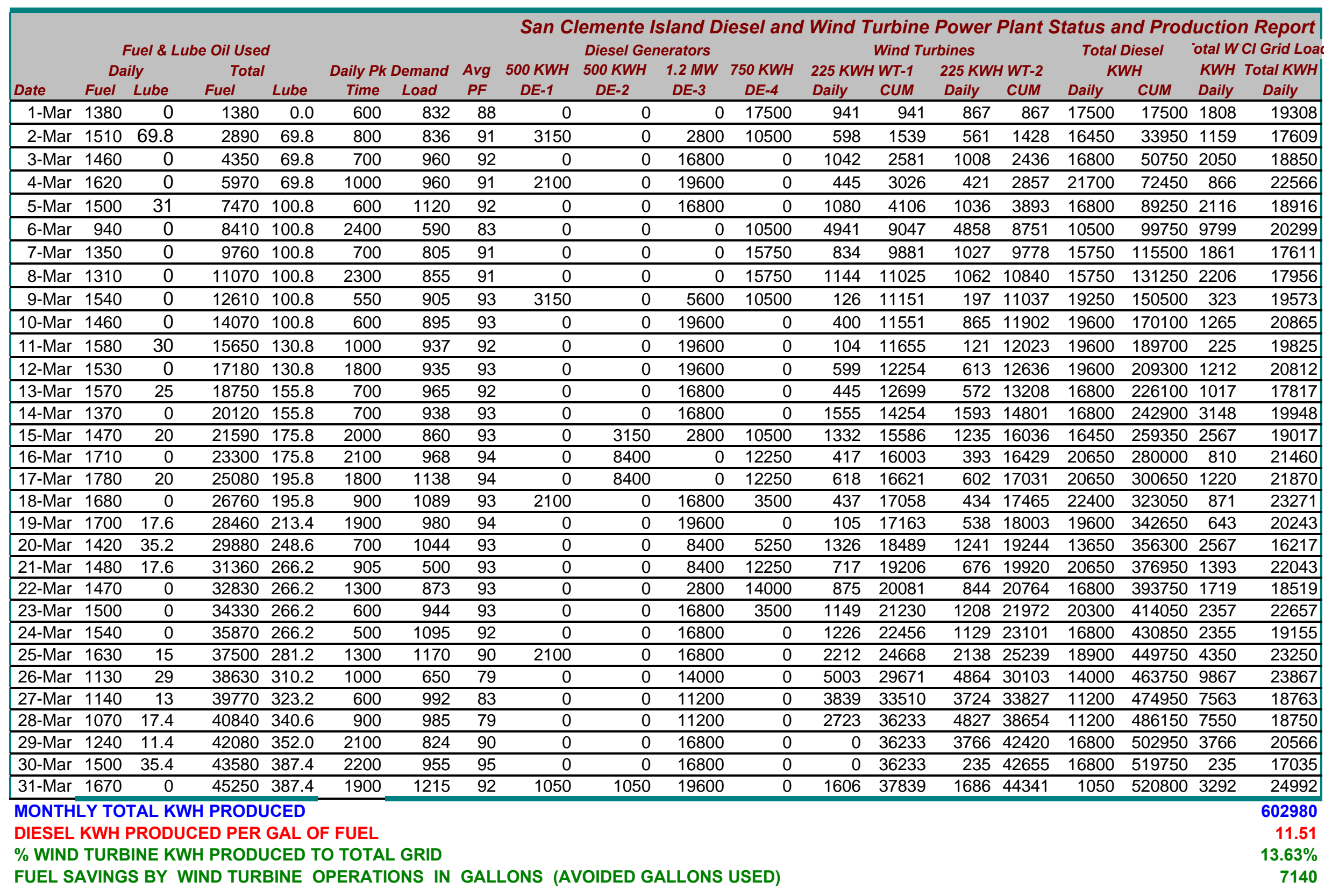


APRIL 1998

\begin{tabular}{|c|c|c|c|c|c|c|c|c|c|c|c|c|c|c|c|c|c|c|c|}
\hline & & & & & & & & & SCl Power & Plant Pro & duction $F$ & eport & & & & & & & \\
\hline & & el \& Lul & Ibe Oil Us & & & & & & Diesel Ger & erators & & & Wind Tu & bines & & Total & Diesel & Tot. WT & Grid Load \\
\hline & Dai & & Tot & & Daily $P$ & mand & Avg & $500 \mathrm{KW}$ & $500 \mathrm{KW}$ & $1.2 \mathrm{MW}$ & $750 \mathrm{KW}$ & $225 \mathrm{KW}$ & $W T-1$ & $225 \mathrm{KW}$ & $W T-2$ & $k V$ & VH & $K W H$ & Tot. KWH \\
\hline Date & Fuel & Lube & Fuel & Lube & Time & Load & PF & $D E-1$ & $D E-2$ & $D E-3$ & $D E-4$ & Daily & CUM & Daily & CUM & Daily & CUM & Daily & Daily \\
\hline 1-Apr & 1670 & 13.5 & 1670 & 13.5 & 2000 & 1019 & 92 & 4200 & 0 & 14000 & 0 & 2094 & 2094 & 2062 & 2062 & 18200 & 18200 & 4156 & 22356 \\
\hline 2-Apr & 1730 & 0 & 3400 & 13.5 & 900 & 1030 & 96 & 1050 & 0 & 22400 & 0 & 160 & 2254 & 164 & 2226 & 23450 & 41650 & 324 & 23774 \\
\hline 3-Apr & 1630 & 13.6 & 5030 & 27.1 & 2400 & 879 & 95 & 1050 & 0 & 8400 & 7000 & 726 & 2980 & 737 & 2963 & 16450 & 58100 & 1463 & 17913 \\
\hline 4-Apr & 1450 & 0 & 6480 & 27.1 & 2400 & 902 & 93 & 1050 & 0 & 0 & 17500 & 491 & 3471 & 480 & 3443 & 18550 & 76650 & 971 & 19521 \\
\hline 5-Apr & 1330 & 0 & 7810 & 27.1 & 500 & 836 & 83 & 1050 & 0 & 0 & 15750 & 1403 & 4874 & 1358 & 4801 & 16800 & 93450 & 2761 & 19561 \\
\hline 6-Apr & 1110 & 0 & 8920 & 27.1 & 2100 & 690 & 84 & 0 & 0 & 0 & 12250 & 4202 & 9076 & 4114 & 8915 & 12250 & 105700 & 8316 & 20566 \\
\hline 7-Apr & 1190 & 7.9 & 10110 & 35.0 & 700 & 917 & 85 & 0 & 0 & 11200 & 5250 & 4183 & 13259 & 4097 & 13012 & 16450 & 122150 & 8280 & 24730 \\
\hline 8-Apr & 1700 & 23.7 & 11810 & 58.7 & 500 & 1082 & 96 & 4200 & 0 & 16800 & 0 & 1454 & 14713 & 1417 & 14429 & 21000 & 143150 & 2871 & 23871 \\
\hline 9-Apr & 1590 & 20 & 13400 & 78.7 & 800 & 972 & 94 & 2100 & 0 & 16800 & 0 & 937 & 15650 & 883 & 15312 & 18900 & 162050 & 1820 & 20720 \\
\hline 10-Apr & 1270 & 18 & 14670 & 96.7 & 2000 & 847 & 94 & 0 & 3150 & 8400 & 1750 & 2451 & 18101 & 2420 & 17732 & 13300 & 175350 & 4871 & 18171 \\
\hline 11-Apr & 1310 & 0 & 15980 & 96.7 & 600 & 881 & 94 & 0 & 1050 & 0 & 14000 & 4986 & 23087 & 4722 & 22454 & 15050 & 190400 & 9708 & 24758 \\
\hline 12-Apr & 920 & 26.5 & 16900 & 123.2 & 1900 & 895 & 85 & 0 & 0 & 0 & 8750 & 4591 & 27678 & 4482 & 26936 & 8750 & 199150 & 9073 & 17823 \\
\hline 13-Apr & 1480 & 0 & 18380 & 123.2 & 1900 & 972 & 90 & 0 & 6300 & 0 & 14000 & 1949 & 29627 & 1913 & 28849 & 20300 & 219450 & 3862 & 24162 \\
\hline 14-Apr & 1700 & 35 & 20080 & 158.2 & 1000 & 975 & 91 & 0 & 8400 & 0 & 10500 & 1316 & 30943 & 1255 & 30104 & 18900 & 238350 & 2571 & 21471 \\
\hline 15-Apr & 1290 & 0 & 21370 & 158.2 & 2400 & 875 & 90 & 0 & 4200 & 8400 & 5250 & 4441 & 35384 & 4497 & 34601 & 17850 & 256200 & 8938 & 26788 \\
\hline 16-Apr & 1660 & 0 & 23030 & 158.2 & 700 & 1068 & 95 & 0 & 2100 & 19600 & 0 & 653 & 36037 & 619 & 35220 & 21700 & 277900 & 1272 & 22972 \\
\hline 17-Apr & 1490 & 61.6 & 24520 & 219.8 & 630 & 1038 & 93 & 0 & 0 & 11200 & 5250 & 315 & 36352 & 424 & 35644 & 16450 & 294350 & 739 & 17189 \\
\hline 18-Apr & 1410 & 0 & 25930 & 219.8 & 700 & 907 & 94 & 0 & 0 & 11200 & 8750 & 516 & 36868 & 291 & 35935 & 19950 & 314300 & 807 & 20757 \\
\hline 19-Apr & 1340 & 0 & 27270 & 219.8 & 630 & 820 & 93 & 0 & 0 & 0 & 15750 & 596 & 37464 & 520 & 36455 & 15750 & 330050 & 1116 & 16866 \\
\hline 20-Apr & 1490 & 0 & 28760 & 219.8 & 600 & 874 & 94 & 0 & 0 & 14000 & 5250 & 298 & 37762 & 269 & 36724 & 19250 & 349300 & 567 & 19817 \\
\hline 21-Apr & 1540 & 0 & 30300 & 219.8 & 2000 & 915 & 94 & 0 & 0 & 19600 & 0 & 153 & 37915 & 148 & 36872 & 19600 & 368900 & 301 & 19901 \\
\hline 22-Apr & 1640 & 22.5 & 31940 & 242.3 & 700 & 1040 & 95 & 0 & 0 & 19600 & 0 & 135 & 38050 & 139 & 37011 & 19600 & 388500 & 274 & 19874 \\
\hline 23-Apr & 1540 & 0 & 33480 & 242.3 & 620 & 1060 & 94 & 0 & 0 & 19600 & 0 & 475 & 38525 & 467 & 37478 & 19600 & 408100 & 942 & 20542 \\
\hline 24-Apr & 1220 & 0 & 34700 & 242.3 & 2100 & 943 & 95 & 0 & 0 & 5600 & 5250 & 2282 & 40807 & 2238 & 39716 & 10850 & 418950 & 4520 & 15370 \\
\hline 25-Apr & 1150 & 0 & 35850 & 242.3 & 700 & 1038 & 95 & 0 & 0 & 0 & 14000 & 2682 & 43489 & 2646 & 42362 & 14000 & 432950 & 5328 & 19328 \\
\hline 26-Apr & 1510 & 25 & 37360 & 267.3 & 600 & 866 & 94 & 0 & 5250 & 0 & 12250 & 362 & 43851 & 333 & 42695 & 17500 & 450450 & 695 & 18195 \\
\hline 27-Apr & 1470 & 0 & 38830 & 267.3 & 2100 & 986 & 94 & 0 & 0 & 19600 & 0 & 553 & 44404 & 514 & 43209 & 19600 & 470050 & 1067 & 20667 \\
\hline 28-Apr & 1630 & 25 & 40460 & 292.3 & 800 & 1032 & 95 & 2100 & 0 & 19600 & 0 & 665 & 45069 & 595 & 43804 & 21700 & 491750 & 1260 & 22960 \\
\hline 29-Apr & 1610 & 0 & 42070 & 292.3 & 900 & 1071 & 94 & 1050 & 0 & 19600 & 0 & 846 & 45915 & 767 & 44571 & 20650 & 512400 & 1613 & 22263 \\
\hline 30-Apr & 1640 & 17.6 & 43710 & 309.9 & 550 & 1075 & 94 & 2100 & 0 & 16800 & 0 & 246 & 46161 & 248 & 44819 & 18900 & 531300 & 494 & 19394 \\
\hline & & & 43710 & & & & & & & & & & 46161 & & 44819 & & 531300 & & \\
\hline$\overline{\text { MONTH }}$ & LY TOT & 'AL KI & $\overline{\text { WH PRC }}$ & DDUCE & & & & & & & & & & & & & & & 622280 \\
\hline DIESEL & KWH P & RODL & UCED P & ER GA & OF FU & & & & & & & & & & & & & & 12.16 \\
\hline$\%$ WIND & TURB & INE KI & WH PRC & DDUCE & TO TC & L GRID & & & & & & & & & & & & & $14.62 \%$ \\
\hline FUEL $S$ & AVINGS & $S B Y$ & WIND T & URBIN & & DNS II & & & & & & & & & & & & & 7485 \\
\hline
\end{tabular}




\section{MAY 1998}

\begin{tabular}{|c|c|c|c|c|c|c|c|c|c|c|c|c|c|c|c|c|c|c|c|}
\hline & & & & & & & & & SCI Power & at Proc & duction $R e$ & port & & & & & & & \\
\hline & & el \& Lut & be Oil Us & & & & & & Diesel Ger & erators & & & Wind Tu & bines & & Total & Diesel & Tot. WT & Grid Load \\
\hline & Dai & & Tot & & Daily PI & emand & Avg & $500 \mathrm{KW}$ & $500 \mathrm{KW}$ & $1.2 M W$ & $750 \mathrm{KW}$ & $225 K W$ & $W T-1$ & $225 \mathrm{Kn}$ & $W W T-2$ & $K V$ & & $K W H$ & Tot. KWH \\
\hline Date & Fuel & Lube & Fuel & Lube & Time & Load & PF & $D E-1$ & $D E-2$ & $D E-3$ & $D E-4$ & Daily & CUM & Daily & CUM & Daily & CUM & Daily & Daily \\
\hline 1-May & 1470 & 4.4 & 1470 & 4.4 & 700 & 905 & 94 & 0 & 0 & 14000 & 5250 & 356 & 356 & 382 & 382 & 19250 & 19250 & 738 & 19988 \\
\hline 2-May & 1270 & 0 & 2740 & 4.4 & 1100 & 760 & 94 & 0 & 0 & 0 & 14000 & 1084 & 1440 & 1098 & 1480 & 14000 & 33250 & 2182 & 16182 \\
\hline 3-May & 1300 & 8.8 & 4040 & 13.2 & 700 & 775 & 94 & 0 & 0 & 0 & 17500 & 567 & 2007 & 597 & 2077 & 17500 & 50750 & 1164 & 18664 \\
\hline 4-May & 1330 & 39.9 & 5370 & 53.1 & 635 & 860 & 94 & 0 & 0 & 11200 & 5250 & 1048 & 3055 & 1039 & 3116 & 16450 & 67200 & 2087 & 18537 \\
\hline 5-May & 1330 & 0 & 6700 & 53.1 & 2100 & 950 & 94 & 0 & 0 & 16800 & 0 & 1597 & 4652 & 1627 & 4743 & 16800 & 84000 & 3224 & 20024 \\
\hline 6-May & 1510 & 0 & 8210 & 53.1 & 900 & 1068 & 95 & 0 & 0 & 16800 & 0 & 604 & 5256 & 606 & 5349 & 16800 & 100800 & 1210 & 18010 \\
\hline 7-May & 1270 & 14 & 9480 & 67.1 & 600 & 912 & 95 & 0 & 0 & 11200 & 3500 & 2101 & 7357 & 2042 & 7391 & 14700 & 115500 & 4143 & 18843 \\
\hline 8-May & 1010 & 0 & 10490 & 67.1 & 700 & 931 & 93 & 0 & 0 & 0 & 12250 & 3378 & 10735 & 3303 & 10694 & 12250 & 127750 & 6681 & 18931 \\
\hline 9-May & 1100 & 10 & 11590 & 77.1 & 800 & 904 & 93 & 0 & 0 & 0 & 14000 & 2698 & 13433 & 2606 & 13300 & 14000 & 141 & 5304 & 19304 \\
\hline 10-May & 1180 & 0 & 12770 & 77.1 & 2300 & 895 & 95 & 0 & 0 & 0 & 14000 & 2505 & 15938 & 2435 & 15735 & 14000 & 155750 & 4940 & 18940 \\
\hline 11-May & 1180 & 20 & 13950 & 97.1 & 2300 & 852 & 94 & 0 & 1050 & 0 & 12250 & 2934 & 18872 & 2875 & 18610 & 13300 & 169050 & 5809 & 19109 \\
\hline 12-May & 1420 & 15 & 15370 & 112.1 & 1900 & 1020 & 93 & 0 & 1050 & 11200 & 3500 & 2266 & 21138 & 2288 & 20898 & 15750 & 184800 & 4554 & 20304 \\
\hline 13-May & 1200 & 4.4 & 16570 & 116.5 & 2200 & 790 & 89 & 0 & 0 & 16800 & 0 & 2386 & 23524 & 2352 & 23250 & 16800 & 201 & 4738 & 21538 \\
\hline 14-May & 1350 & 28 & 17920 & 144.5 & 500 & 878 & 90 & 0 & 0 & 16800 & 0 & 1807 & 25331 & 1727 & 24977 & 16800 & 218400 & 3534 & 20334 \\
\hline 15-May & 1290 & 0 & 19210 & 144.5 & 700 & 854 & 91 & 0 & 0 & 11200 & 5250 & 1452 & 26783 & 1360 & 26337 & 16450 & 234850 & 2812 & 19262 \\
\hline 16-May & 1090 & 0 & 20300 & 144.5 & 700 & 797 & 81 & 0 & 0 & 0 & 14000 & 2454 & 29237 & 2418 & 28755 & 14000 & 248850 & 4872 & 18872 \\
\hline 17-May & 1190 & 1.5 & 21490 & 146.0 & 700 & 812 & 90 & 0 & 0 & 0 & 14000 & 1707 & 30944 & 1732 & 30487 & 14000 & 262850 & 3439 & 17439 \\
\hline 18-May & 1400 & 0 & 22890 & 146.0 & 700 & 838 & 91 & 0 & 0 & 14000 & 3500 & 809 & 31753 & 743 & 31230 & 17500 & 280350 & 1552 & 19052 \\
\hline 19-May & 1430 & 0 & 24320 & 146.0 & 1500 & 825 & 92 & 0 & 0 & 16800 & 0 & 1289 & 33042 & 1206 & 32436 & 16800 & 297150 & 2495 & 19295 \\
\hline 20-May & 1450 & 22 & 25770 & 168.0 & 2200 & 1004 & 93 & 0 & 0 & 16800 & 0 & 2003 & 35045 & 1914 & 34350 & 16800 & 313950 & 3917 & 20717 \\
\hline 21-May & 1460 & 0 & 27230 & 168.0 & 2300 & 1088 & 94 & 0 & 0 & 19600 & 0 & 1727 & 36772 & 1665 & 36015 & 19600 & 333550 & 3392 & 22992 \\
\hline 22-May & 1360 & 18 & 28590 & 186.0 & 600 & 1037 & 94 & 0 & 0 & 14000 & 0 & 2127 & 38899 & 2035 & 38050 & 14000 & 347550 & 4162 & 18162 \\
\hline 23-May & 1400 & 20 & 29990 & 206.0 & 700 & 895 & 93 & 3150 & 0 & 0 & 12250 & 1361 & 40260 & 1286 & 39336 & 15400 & 362950 & 2647 & 18047 \\
\hline 24-May & 1390 & 20 & 31380 & 226.0 & 2400 & 938 & 93 & 4200 & 0 & 0 & 14000 & 1461 & 41721 & 1405 & 40741 & 18200 & 381 & 2866 & 21066 \\
\hline 25-May & 1210 & 0 & 32590 & 226.0 & 600 & 979 & 94 & 0 & 0 & 0 & 14000 & 2397 & 44118 & 2301 & 43042 & 14000 & 395150 & 4698 & 18698 \\
\hline 26-May & 1150 & 20 & 33740 & 246.0 & 1900 & 930 & 93 & 0 & 0 & 2800 & 12250 & 3620 & 47738 & 3512 & 46554 & 15050 & 410200 & 7132 & 22182 \\
\hline 27-May & 1450 & 0 & 35190 & 246.0 & 2200 & 852 & 93 & 1050 & 0 & 16800 & 0 & 1404 & 49142 & 1325 & 47879 & 17850 & 428050 & 2729 & 20579 \\
\hline 28-May & 1550 & 10 & 36740 & 256.0 & 1400 & 830 & 93 & 1050 & 0 & 16800 & 0 & 806 & 49948 & 732 & 48611 & 17850 & 445900 & 1538 & 19388 \\
\hline 29-May & 1280 & 0 & 38020 & 256.0 & 600 & 786 & 89 & 0 & 0 & 14000 & 0 & 2616 & 52564 & 2531 & 51142 & 14000 & 459900 & 5147 & 19147 \\
\hline 30-May & 1430 & 31 & 39450 & 287.0 & 2300 & 849 & 93 & 0 & 0 & & 0 & 724 & 53288 & 672 & 51814 & 19600 & & 1396 & 20996 \\
\hline 31-May & 1490 & 0 & 40940 & 287.0 & 600 & 873 & 92 & 0 & 0 & 16800 & 0 & 333 & 53621 & 306 & 52120 & 16800 & 496300 & 639 & 17439 \\
\hline MONTH & IY TO] & & 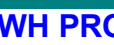 & ODUCE & & & & & & & & & & & & & & & 602041 \\
\hline DIESEL & KWH P & PRODL & UCED $P$ & PER GAL & - OF FU & & & & & & & & & & & & & & 12.12 \\
\hline$\%$ WIND & TURB & INE KV & WH PRC & ODUCEI & D TO TC & GRID & & & & & & & & & & & & & $17.56 \%$ \\
\hline FUEL $S$ & AVINGS & DY & VIIVE & URDIINL & & n & & 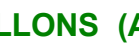 & IIJLE & LEL & USED) & & & & & & & & 8723 \\
\hline
\end{tabular}




\section{JUNE 1998}

\begin{tabular}{|c|c|c|c|c|c|c|c|c|c|c|c|c|c|c|c|c|c|c|c|}
\hline & & & & & & & & & Cl Power & Plant Proc & duction $R$ & port & & & & & & & \\
\hline & & el \& Lut & be Oil Us & & & & & & Diesel Ger & nerators & & & Wind Tu & rbines & & Total & Diesel & Tot. WT & Grid Load \\
\hline & Da & & Tot & & Daily $P k$ & emand & Avg & $500 \mathrm{KW}$ & $500 \mathrm{KW}$ & $1.2 \mathrm{MW}$ & $750 \mathrm{KW}$ & $225 \mathrm{KW}$ & $W T-1$ & $225 \mathrm{KW}$ & $V W T-2$ & $K V$ & & $K W H$ & Tot. KWH \\
\hline Date & Fuel & Lube & Fuel & Lube & Time & Load & PF & $D E-1$ & $D E-2$ & $D E-3$ & $D E-4$ & Daily & CUM & Daily & CUM & Daily & CUM & Daily & Daily \\
\hline 1-Jun & 1430 & 0 & 1430 & 0.0 & 700 & 866 & 93 & 0 & 0 & 19600 & 0 & 1277 & 1277 & 1193 & 1193 & 19600 & 19600 & 2470 & 22070 \\
\hline 2-Jun & 1170 & 26.4 & 2600 & 26.4 & 200 & 649 & 87 & 0 & 0 & 11200 & 0 & 3891 & 5168 & 3730 & 4923 & 11200 & 30800 & 7621 & 18821 \\
\hline 3-Jun & 1390 & 0 & 3990 & 26.4 & 1400 & 997 & 90 & 0 & 0 & 16800 & 0 & 2659 & 7827 & 2537 & 7460 & 16800 & 47600 & 5196 & 21996 \\
\hline 4-Jun & 1460 & 20 & 5450 & 46.4 & 700 & 944 & 91 & 1050 & 0 & 16800 & 0 & 1973 & 9800 & 1889 & 9349 & 17850 & 65450 & 3862 & 21712 \\
\hline 5-Jun & 1250 & 0 & 6700 & 46.4 & 600 & 1009 & 88 & 0 & 0 & 16800 & 0 & 2646 & 12446 & 2541 & 11890 & 16800 & 82250 & 5187 & 21987 \\
\hline 6-Jun & 1320 & 25 & 8020 & 71.4 & 1100 & 922 & 92 & 0 & 0 & 14000 & 0 & 1781 & 14227 & 1719 & 13609 & 14000 & 96250 & 3500 & 17500 \\
\hline 7-Jun & 1310 & 4.4 & 9330 & 75.8 & 2100 & 840 & 92 & 0 & 0 & 16800 & 0 & 1855 & 16082 & 1771 & 15380 & 16800 & 113050 & 3626 & 20426 \\
\hline 8-Jun & 1450 & 0 & 10780 & 75.8 & 1900 & 976 & 91 & 0 & 0 & 16800 & 0 & 1369 & 17451 & 1327 & 16707 & 16800 & 129850 & 2696 & 19496 \\
\hline 9-Jun & 1700 & 22 & 12480 & 97.8 & 1100 & 1014 & 92 & 2100 & 0 & 16800 & 0 & 303 & 17754 & 269 & 16976 & 18900 & 148750 & 572 & 19472 \\
\hline 10-Jun & 1600 & 0 & 14080 & 97.8 & 700 & 1217 & 92 & 2100 & 0 & 16800 & 0 & 1218 & 18972 & 1155 & 18131 & 18900 & 167650 & 2373 & 21273 \\
\hline 11-Jun & 1430 & 13.2 & 15510 & 111.0 & 600 & 944 & 91 & 0 & 0 & 19600 & 0 & 1610 & 20582 & 1548 & 19679 & 19600 & 187250 & 3158 & 22758 \\
\hline 12-Jun & 1270 & 8.8 & 16780 & 119.8 & 2200 & 861 & 92 & 0 & 0 & 14000 & 0 & 749 & 21331 & 731 & 20410 & 14000 & 201250 & 1480 & 15480 \\
\hline 13-Jun & 1370 & 0 & 18150 & 119.8 & 700 & 834 & 91 & 0 & 0 & 16800 & 0 & 1624 & 22955 & 1591 & 22001 & 16800 & 218050 & 3215 & 20015 \\
\hline 14-Jun & 1380 & 0 & 19530 & 119.8 & 1000 & 786 & 91 & 0 & 0 & 2800 & 10500 & 1766 & 24721 & 1646 & 23647 & 13300 & 231350 & 3412 & 16712 \\
\hline 15-Jun & 1550 & 0 & 21080 & 119.8 & 700 & 878 & 90 & 0 & 5250 & 0 & 12250 & 923 & 25644 & 890 & 24537 & 17500 & 248850 & 1813 & 19313 \\
\hline 16-Jun & 1660 & 0 & 22740 & 119.8 & 700 & 971 & 94 & 0 & 7350 & 0 & 12250 & 468 & 26112 & 453 & 24990 & 19600 & 268450 & 921 & 20521 \\
\hline \begin{tabular}{|l}
$17-J u n$ \\
\end{tabular} & 1730 & 30.8 & 24470 & 150.6 & 700 & 1092 & 95 & 0 & 8400 & 0 & 12250 & 526 & 26638 & 523 & 25513 & 20650 & 289100 & 1049 & 21699 \\
\hline 18-Jun & 1650 & 17.6 & 26120 & 168.2 & 2100 & 915 & 93 & 0 & 8400 & 0 & 12250 & 210 & 26848 & 199 & 25712 & 20650 & 309750 & 409 & 21059 \\
\hline 19-Jun & 1530 & 13.2 & 27650 & 181.4 & 900 & 906 & 93 & 0 & 5250 & 0 & 12250 & 784 & 27632 & 745 & 26457 & 17500 & 327250 & 1529 & 19029 \\
\hline 20-Jun & 1240 & 0 & 28890 & 181.4 & 1400 & 712 & 91 & 0 & 0 & 0 & 14000 & 1354 & 28986 & 1296 & 27753 & 14000 & 341250 & 2650 & 16650 \\
\hline 21-Jun & 1220 & 0 & 30110 & 181.4 & 1600 & 830 & 92 & 0 & 0 & 0 & 15750 & 1687 & 30673 & 1650 & 29403 & 15750 & 357000 & 3337 & 19087 \\
\hline \begin{tabular}{|l|} 
22-Jun \\
\end{tabular} & 1340 & 50 & 31450 & 231.4 & 2200 & 845 & 91 & 0 & 0 & 16800 & 1750 & 1497 & 32170 & 1447 & 30850 & 18550 & 375550 & 2944 & 21494 \\
\hline \begin{tabular}{|l} 
23-Jun \\
\end{tabular} & 1330 & 4.4 & 32780 & 235.8 & 800 & 929 & 89 & 0 & 0 & 14000 & 0 & 2050 & 34220 & 1956 & 32806 & 14000 & 389550 & 4006 & 18006 \\
\hline 24-Jun & 1390 & 0 & 34170 & 235.8 & 1100 & 905 & 90 & 0 & 0 & 16800 & 0 & 1652 & 35872 & 1605 & 34411 & 16800 & 406350 & 3257 & 20057 \\
\hline 25-Jun & 1380 & 0 & 35550 & 235.8 & 1400 & 860 & 90 & 0 & 0 & 16800 & 0 & 1599 & 37471 & 1519 & 35930 & 16800 & 423150 & 3118 & 19918 \\
\hline 26-Jun & 1330 & 22.2 & 36880 & 258.0 & 1000 & 870 & 90 & 0 & 0 & 11200 & 3500 & 1634 & 39105 & 1538 & 37468 & 14700 & 437850 & 3172 & 17872 \\
\hline 27-Jun & 1360 & 0 & 38240 & 258.0 & 2100 & 880 & 90 & 0 & 0 & 0 & 15750 & 1184 & 40289 & 1099 & 38567 & 15750 & 453600 & 2283 & 18033 \\
\hline \begin{tabular}{|l} 
28-Jun \\
\end{tabular} & 1250 & 24 & 39490 & 282.0 & 2100 & 840 & 91 & 0 & 0 & 0 & 14000 & 2121 & 42410 & 1965 & 40532 & 14000 & 467600 & 4086 & 18086 \\
\hline 29-Jun & 1180 & 0 & 40670 & 282.0 & 1900 & 920 & 90 & 0 & 0 & 0 & 14000 & 3082 & 45492 & 2921 & 43453 & 14000 & 481600 & 6003 & 20003 \\
\hline 30-Jun & 1110 & 0 & 41780 & 282.0 & 700 & 940 & 91 & 0 & 0 & 0 & 14000 & 3763 & 49255 & 3519 & 46972 & 14000 & 495600 & 7282 & 21282 \\
\hline & & & 41780 & & & & & & & & & & 49255 & & 46972 & & 495600 & & \\
\hline MONTR & [YY TO1 & $\overline{A L L I}$ & $\overline{W H}$ PRC & ODUCĒ & & & & & & & & & & & & & & & 591827 \\
\hline DIESEL & KWH F & RODL & UCED P & PER GAL & OF FU & & & & & & & & & & & & & & 11.86 \\
\hline$\%$ WIN & TURB & INE KI & WH PRC & ODUCE & D то то & L GRID & & & & & & & & & & & & & $16.26 \%$ \\
\hline FUEL S & AVING & $S B Y$ & WIND T & CURBINE & $=0$ & & & & & & & & & & & & & & 8112 \\
\hline
\end{tabular}




\section{JULY 1998}

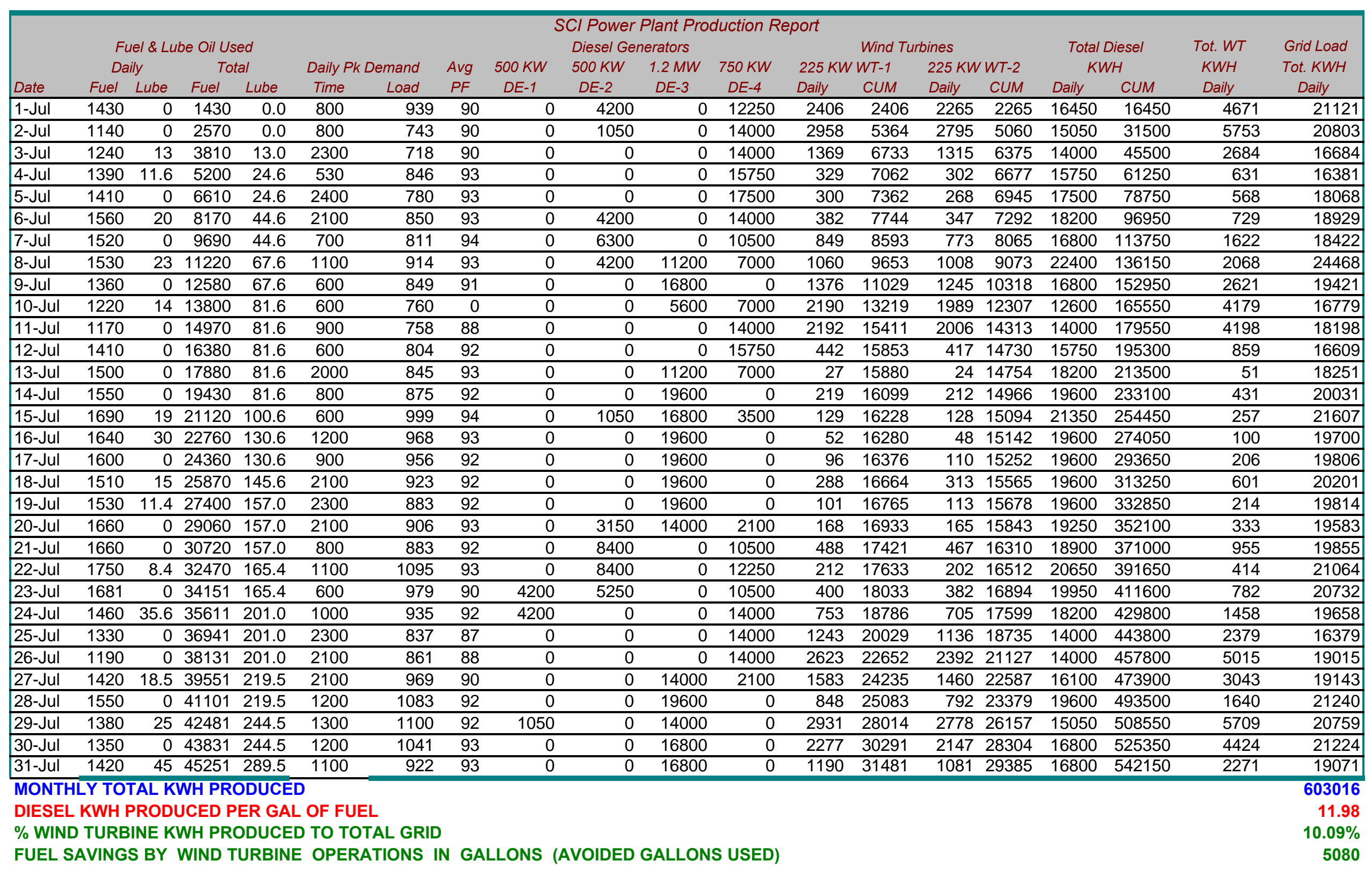


AUGUST 1998

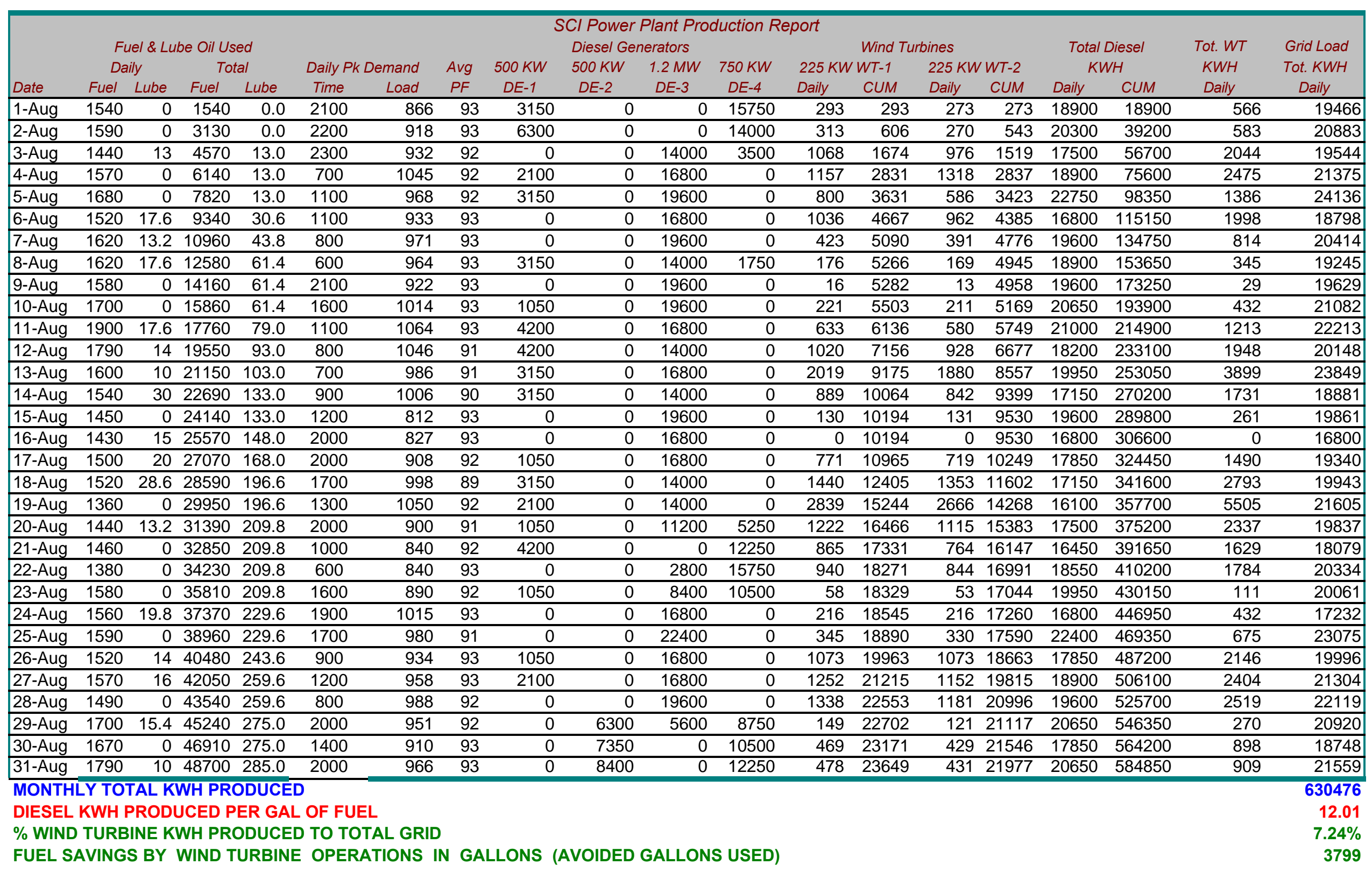




\section{SEPTEMBER 1998}

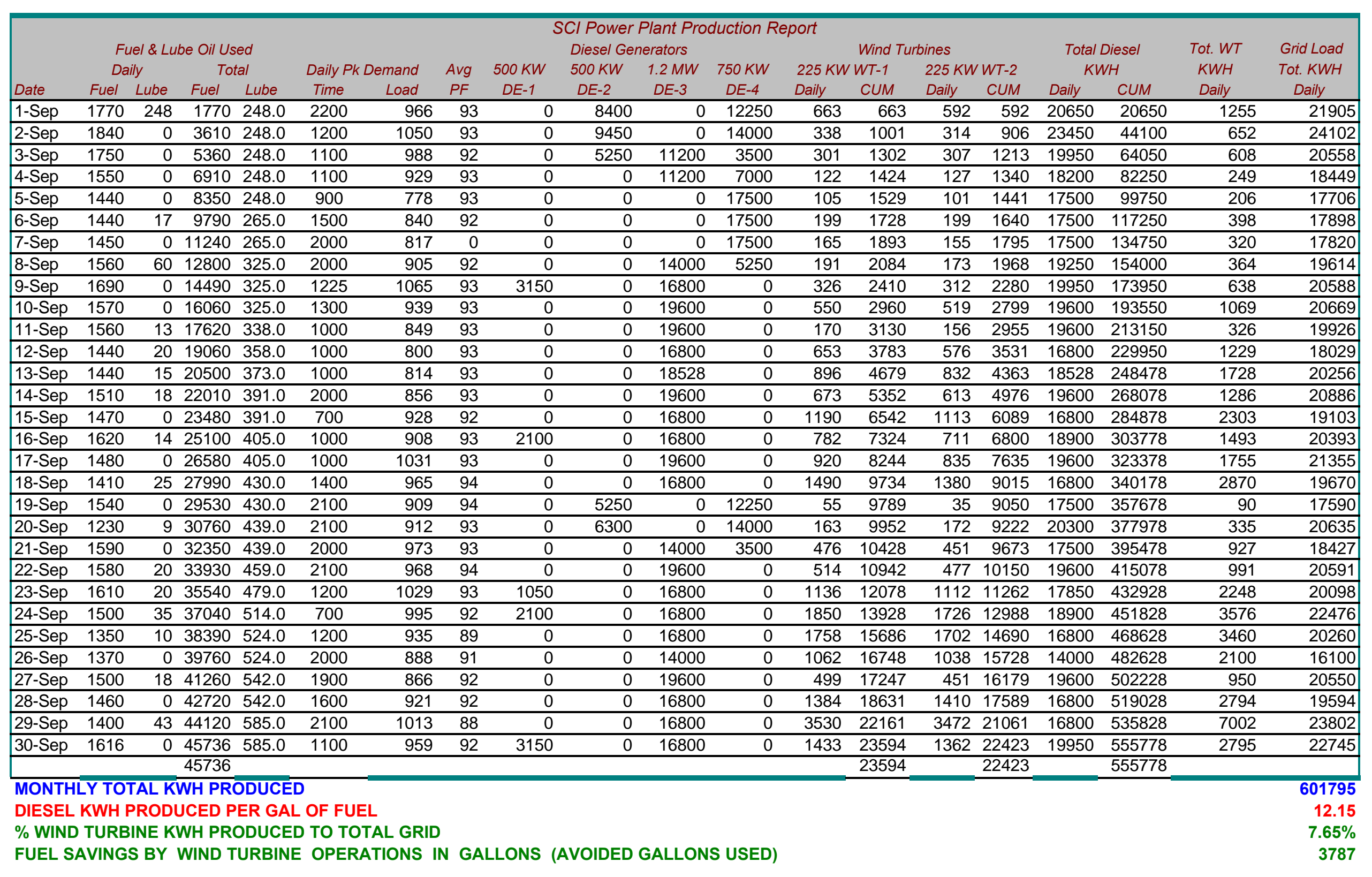


OCTOBER 1998

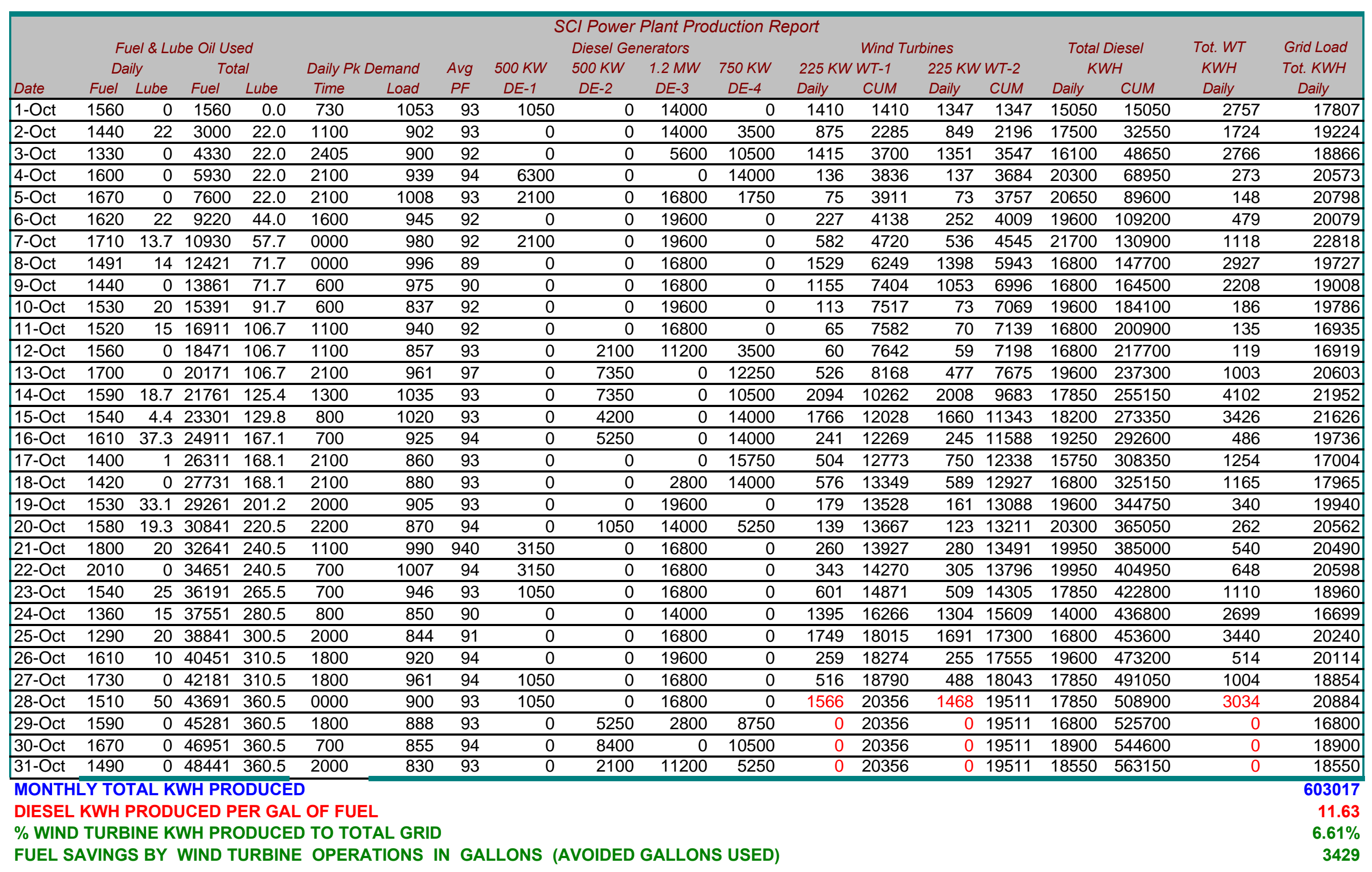


NOVEMBER 1998

\begin{tabular}{|c|c|c|c|c|c|c|c|c|c|c|c|c|c|c|c|c|c|c|c|}
\hline & & & & & & & & & Cl Power & Plant Proc & duction $R$ & port & & & & & & & \\
\hline & & sel \& Lut & be Oil Us & & & & & & Diesel Ger & erators & & & Wind Tur & bines & & Total & Diesel & Tot. WT & Grid Load \\
\hline & Dai & & Tot & & Daily $P k$ & emand & Avg & $500 \mathrm{KW}$ & $500 \mathrm{KW}$ & $1.2 \mathrm{MW}$ & $750 \mathrm{KW}$ & $225 K W$ & $W T-1$ & $225 \mathrm{KW}$ & $W T-2$ & $K V$ & VH & $K W H$ & Tot. KWH \\
\hline Date & Fuel & Lube & Fuel & Lube & Time & Load & $P F$ & $D E-1$ & $D E-2$ & $D E-3$ & $D E-4$ & Daily & CUM & Daily & CUM & Daily & CUM & Daily & Daily \\
\hline 1-Nov & 1530 & 0 & 1530 & 0.0 & 1800 & 827 & 94 & 0 & 0 & 19600 & 0 & 0 & 0 & 0 & 0 & 19600 & 19600 & 0 & 19600 \\
\hline 2-Nov & 1650 & 0 & 3180 & 0.0 & 1700 & 1200 & 95 & 1050 & 0 & 19600 & 0 & 0 & 0 & 0 & 0 & 20650 & 40250 & 0 & 1610 \\
\hline 3-Nov & 1610 & 46 & 4790 & 46.0 & 700 & 1100 & 94 & 1050 & 0 & 19600 & 0 & 2011 & 2011 & 1829 & 1829 & 20650 & 60900 & 3840 & 24490 \\
\hline 4-Nov & 1670 & 0 & 6460 & 46.0 & 600 & 1038 & 94 & 3150 & 0 & 16800 & 0 & 3094 & 5105 & 2805 & 4634 & 19950 & 80850 & 5899 & 25849 \\
\hline 5-Nov & 1680 & 17.6 & 8140 & 63.6 & 600 & 982 & 94 & 2100 & 0 & 16800 & 0 & 1210 & 6315 & 1142 & 5776 & 18900 & 99750 & 2352 & 21252 \\
\hline 6-Nov & 1440 & 0 & 9580 & 63.6 & 700 & 921 & 94 & 0 & 0 & 16800 & 0 & 2235 & 8550 & 2291 & 8067 & 16800 & 116550 & 4526 & 21326 \\
\hline 7-Nov & 1550 & 27 & 11130 & 90.6 & 1800 & 938 & 94 & 2100 & 0 & 16800 & 0 & 1542 & 10092 & 1663 & 9730 & 18900 & 135450 & 3205 & 22105 \\
\hline 8-Nov & 1910 & 13.2 & 13040 & 103.8 & 1100 & 960 & 94 & 1050 & 0 & 16800 & 0 & 3842 & 13934 & 3694 & 13424 & 17850 & 153300 & 7536 & 25386 \\
\hline 9-Nov & 1590 & 53 & 14630 & 156.8 & 1900 & 1029 & 94 & 2100 & 0 & 14000 & 0 & 525 & 14459 & 694 & 14118 & 16100 & 169400 & 1219 & 17319 \\
\hline 10-Nov & 1880 & 0 & 16510 & 156.8 & 600 & 1150 & 94 & 5250 & 0 & 16800 & 0 & 347 & 14806 & 313 & 14431 & 22050 & 191450 & 660 & 22710 \\
\hline 11-Nov & 1970 & 0 & 18480 & 156.8 & 600 & 1089 & 94 & 7350 & 0 & 16800 & 0 & 296 & 15102 & 456 & 14887 & 24150 & 215600 & 752 & 24902 \\
\hline 12-Nov & 1790 & 25 & 20270 & 181.8 & 600 & 1059 & 95 & 4200 & 0 & 16800 & 0 & 360 & 15462 & 467 & 15354 & 21000 & 236600 & 827 & 21827 \\
\hline 13-Nov & 1660 & 25 & 21930 & 206.8 & 700 & 1025 & 95 & 1050 & 0 & 19600 & 0 & 354 & 15816 & 362 & 15716 & 20650 & 257250 & 716 & 21366 \\
\hline 14-Nov & 1580 & 15 & 23510 & 221.8 & 600 & 958 & 94 & 0 & 3150 & 0 & 15750 & 522 & 16338 & 468 & 16184 & 18900 & 276150 & 990 & 19890 \\
\hline 15-Nov & 1630 & 25 & 25140 & 246.8 & 2300 & 1053 & 95 & 0 & 5250 & 0 & 15750 & 741 & 17079 & 655 & 16839 & 21000 & 297150 & 1396 & 22396 \\
\hline 16-Nov & 1650 & 0 & 26790 & 246.8 & 2200 & 962 & 94 & 0 & 7350 & 0 & 12250 & 1194 & 18273 & 1138 & 17977 & 19600 & 316750 & 2332 & 21932 \\
\hline 17-Nov & 1780 & 10 & 28570 & 256.8 & 1800 & 1196 & 95 & 0 & 8400 & 0 & 12250 & 1475 & 19748 & 1424 & 19401 & 20650 & 337400 & 2899 & 23549 \\
\hline 18-Nov & 1950 & 0 & 30520 & 256.8 & 700 & 1129 & 95 & 0 & 9450 & 0 & 14000 & 217 & 19965 & 213 & 19614 & 23450 & 360850 & 430 & 23880 \\
\hline 19-Nov & 1940 & 35 & 32460 & 291.8 & 700 & 1121 & 96 & 0 & 9450 & 0 & 14000 & 193 & 20158 & 200 & 19814 & 23450 & 384300 & 393 & 23843 \\
\hline $20-N o v$ & 1850 & 0 & 34310 & 291.8 & 700 & 1154 & 96 & 0 & 8400 & 0 & 14000 & 207 & 20365 & 192 & 20006 & 22400 & 406700 & 399 & 22799 \\
\hline 21-Nov & 1760 & 0 & 36070 & 291.8 & 2355 & 1074 & 96 & 0 & 6300 & 5600 & 7000 & 292 & 20657 & 247 & 20253 & 18900 & 425600 & 539 & 19439 \\
\hline 22-Nov & 1740 & 50 & 37810 & 341.8 & 200 & 972 & 95 & 0 & 3150 & 19600 & 0 & 596 & 21253 & 548 & 20801 & 22750 & 448350 & 1144 & 23894 \\
\hline 23-Nov & 1940 & 30 & 39750 & 371.8 & 1200 & 1013 & 95 & 0 & 5250 & 16800 & 0 & 1439 & 22692 & 1314 & 22115 & 22050 & 470400 & 2753 & 24803 \\
\hline 24-Nov & 1780 & 0 & 41530 & 371.8 & 800 & 1121 & 95 & 0 & 7350 & 14000 & 0 & 1064 & 23756 & 1044 & 23159 & 21350 & 491750 & 2108 & 23458 \\
\hline $25-\mathrm{Nov}$ & 1700 & 52.8 & 43230 & 424.6 & 600 & 1044 & 94 & 0 & 2100 & 19600 & 0 & 266 & 24022 & 248 & 23407 & 21700 & 513450 & 514 & 22214 \\
\hline 26-Nov & 1570 & 0 & 44800 & 424.6 & 2000 & 1025 & 94 & 1050 & 0 & 19600 & 0 & 921 & 24943 & 812 & 24219 & 20650 & 534100 & 1733 & 22383 \\
\hline 27-Nov & 1740 & 37.4 & 46540 & 462.0 & 630 & 1060 & 95 & 3150 & 0 & 16800 & 0 & 270 & 25213 & 259 & 24478 & 19950 & 554050 & 529 & 20479 \\
\hline 28-Nov & 1190 & 26.4 & 47730 & 488.4 & 1700 & 1010 & 88 & 0 & 0 & 14000 & 0 & 5030 & 30243 & 2808 & 27286 & 14000 & 568050 & 7838 & 21838 \\
\hline 29-Nov & 1590 & 0 & 49320 & 488.4 & 2000 & 965 & 94 & 0 & 0 & 19600 & 0 & 1669 & 31912 & 0 & 27286 & 19600 & 587650 & 1669 & 21269 \\
\hline 30-Nov & 1860 & 39.6 & 51180 & 528.0 & 2000 & 1080 & 94 & 2100 & 1050 & 16800 & 0 & 243 & 32155 & 76 & 27362 & 19950 & 607600 & 319 & 20269 \\
\hline & & & 51180 & & & & & & & & & & 32155 & & 27362 & & 607600 & & \\
\hline MONTH & LY TOT & TAL KI & $\overline{\text { WH PRC }}$ & ODUCĒ & & & & & & & & & & & & & & & 667117 \\
\hline DIESEL & KWH P & PRODL & UCED P & 'ER GAL & OF FU & & & & & & & & & & & & & & 11.87 \\
\hline$\%$ WIND & TURB & INE KI & WH PRC & ODUCE & D TO TC & L GRID & & & & & & & & & & & & & $8.92 \%$ \\
\hline FUEL S & AVINGS & $S$ BY & WIND T & CURBINE & & & & & & & & & & & & & & & 5013 \\
\hline
\end{tabular}

11-Nov-98 Production.xls Nov 1-3 WT Production lost due to Navy Utilities construction for 3rd Wind Turbine Installation 


\section{DECEMBER 1998}

\begin{tabular}{|c|c|c|c|c|c|c|c|c|c|c|c|c|c|c|c|c|c|c|c|}
\hline \multirow[b]{3}{*}{ Date } & \multicolumn{15}{|c|}{ SCI Power Plant Production Report } & \multirow{2}{*}{\multicolumn{2}{|c|}{$\begin{array}{c}\text { Total Diesel } \\
\text { KWH }\end{array}$}} & \multirow{3}{*}{$\begin{array}{c}\text { Tot. WT } \\
\text { KWH } \\
\text { Daily }\end{array}$} & \multirow{3}{*}{$\begin{array}{l}\text { Grid Load } \\
\text { Tot. KWH } \\
\text { Daily }\end{array}$} \\
\hline & \multicolumn{2}{|c|}{ Daily } & \multicolumn{2}{|c|}{ Total } & \multicolumn{2}{|c|}{ Daily Pk Demand } & \multirow{2}{*}{$\begin{array}{l}\text { Avg } \\
\text { PF }\end{array}$} & \multirow{2}{*}{$\begin{array}{c}500 \mathrm{KW} \\
\mathrm{DE}-1 \\
\end{array}$} & \multirow{2}{*}{$\begin{array}{c}500 \mathrm{KW} \\
\mathrm{DE}-2 \\
\end{array}$} & \multirow{2}{*}{$\begin{array}{c}1.2 \mathrm{MW} \\
\mathrm{DE}-3\end{array}$} & \multirow{2}{*}{$\begin{array}{c}750 K W \\
D E-4 \\
\end{array}$} & \multicolumn{2}{|c|}{$225 K W W T-1$} & \multicolumn{2}{|c|}{$225 K W W T-2$} & & & & \\
\hline & Fuel & Lube & Fuel & Lube & Time & Load & & & & & & Daily & CUM & Daily & CUM & \multicolumn{2}{|c|}{ Daily CUM } & & \\
\hline 2-Dec & 2040 & 17.6 & 4020 & 26.4 & 2000 & 1175 & 96 & 7350 & 0 & 16800 & 0 & 197 & 971 & 200 & 1712 & 24150 & 46200 & 397 & 24547 \\
\hline 3-Dec & 2910 & 0 & 6930 & 26.4 & 600 & 1216 & 95 & 6300 & 0 & 16800 & 0 & 1330 & 2301 & 1473 & 3185 & 23100 & 69300 & 2803 & 25903 \\
\hline 4-Dec & 1950 & 32.2 & 8880 & 58.6 & 700 & 1009 & 92 & 4200 & 0 & 16800 & 0 & 2498 & 4799 & 2417 & 5602 & 21000 & 90300 & 4915 & 25915 \\
\hline 5-Dec & 1460 & 0 & 10340 & 58.6 & 700 & 1014 & 95 & 7350 & 0 & 2800 & 10500 & 0 & 4799 & 0 & 5602 & 20650 & 110950 & 0 & 20650 \\
\hline 6-Dec & 1750 & 0 & 12090 & 58.6 & 600 & 1129 & 96 & 7350 & 0 & 0 & 12250 & 0 & 4799 & 0 & 5602 & 19600 & 130550 & 0 & 19600 \\
\hline 7-Dec & 1990 & 19.4 & 14080 & 78.0 & 1800 & 1130 & 97 & 9450 & 0 & 0 & 15750 & 4267 & 9066 & 5680 & 11282 & 25200 & 155750 & 9947 & 35147 \\
\hline 8-Dec & 2070 & 20 & 16150 & 98.0 & 500 & 1317 & 96 & 8400 & 0 & 11200 & 3500 & 876 & 9942 & 994 & 12276 & 23100 & 178850 & 1870 & 24970 \\
\hline 9-Dec & 1860 & 0 & 18010 & 98.0 & 1800 & 1150 & 95 & 6300 & 0 & 14000 & 0 & 2362 & 12304 & 2320 & 14596 & 20300 & 199150 & 4682 & 24982 \\
\hline 10-Dec & 2080 & 0 & 20090 & 98.0 & 700 & 1200 & 96 & 0 & 6300 & 19600 & 0 & 173 & 12477 & 251 & 14847 & 25900 & 225050 & 424 & 26324 \\
\hline 11-Dec & 1850 & 25 & 21940 & 123.0 & 700 & 1200 & 96 & 0 & 4200 & 16800 & 0 & 158 & 12635 & 185 & 15032 & 21000 & 246050 & 343 & 21343 \\
\hline 12-Dec & 1720 & 7 & 23660 & 130.0 & 800 & 990 & 95 & 0 & 5250 & 5600 & 8750 & 30 & 12665 & 286 & 15318 & 19600 & 265650 & 316 & 19916 \\
\hline 13-Dec & 1590 & 10 & 25250 & 140.0 & 600 & 900 & 96 & 0 & 5250 & 5600 & 8750 & 1249 & 13914 & 1147 & 16465 & 19600 & 285250 & 2396 & 21996 \\
\hline 15-Dec & 1730 & 37 & 28580 & 181.0 & 1100 & 1028 & 96 & 4200 & 2100 & 5600 & 8750 & 1260 & 17740 & 1675 & 21203 & 20650 & 323750 & 2935 & 23585 \\
\hline 16-Dec & 1780 & 20 & 30360 & 201.0 & 1200 & 1056 & 96 & 5250 & 0 & 16800 & 0 & 835 & 18575 & 1455 & 22658 & 22050 & 345800 & 2290 & 24340 \\
\hline 17-Dec & 1650 & 0 & 32010 & 201.0 & 1100 & 1184 & 94 & 1050 & 0 & 19600 & 0 & 739 & 19314 & 673 & 23331 & 20650 & 366450 & 1412 & 22062 \\
\hline 18-Dec & 1490 & 13.7 & 33500 & 214.7 & 1800 & 1091 & 94 & 6300 & 0 & 16800 & 0 & 97 & 19411 & 90 & 23421 & 23100 & 389550 & 187 & 23287 \\
\hline 19-Dec & 1530 & 3.9 & 35030 & 218.6 & 1900 & 1048 & 95 & 0 & 0 & 11200 & 0 & 1527 & 20938 & 1483 & 24904 & 11200 & 400750 & 3010 & 14210 \\
\hline 20-Dec & 1320 & 16.3 & 36350 & 234.9 & 2000 & 1091 & 86 & 0 & 0 & 16800 & 0 & 3892 & 24830 & 3804 & 28708 & 16800 & 417550 & 7696 & 24496 \\
\hline 21-Dec & 1860 & 27 & 38210 & 261.9 & 1800 & 1154 & 96 & 6300 & 0 & 14000 & 3500 & 951 & 25781 & 1062 & 29770 & 23800 & 441350 & 2013 & 25813 \\
\hline 22-Dec & 2010 & 13 & 40220 & 274.9 & 700 & 1200 & 95 & 5250 & 0 & 16800 & 0 & 479 & 26260 & 498 & 30268 & 22050 & 463400 & 977 & 23027 \\
\hline 23-Dec & 1830 & 0 & 42050 & 274.9 & 700 & 1100 & 97 & 4200 & 0 & 19600 & 0 & 449 & 26709 & 516 & 30784 & 23800 & 487200 & 965 & 24765 \\
\hline 24-Dec & 1800 & 35 & 43850 & 309.9 & 600 & 1100 & 96 & 1050 & 0 & 16800 & 0 & 194 & 26903 & 225 & 31009 & 17850 & 505050 & 419 & 18269 \\
\hline 25-Dec & 1670 & 15 & 45520 & 324.9 & 600 & 1016 & 96 & 1050 & 0 & 22400 & 0 & 341 & 27244 & 326 & 31335 & 23450 & 528500 & 667 & 24117 \\
\hline 26-Dec & 1610 & 0 & 47130 & 324.9 & 600 & 912 & 96 & 9450 & 10500 & 0 & 0 & 117 & 27361 & 147 & 31482 & 19950 & 548450 & 264 & 20214 \\
\hline 27-Dec & 1580 & 0 & 48710 & 324.9 & 600 & 920 & 96 & 9450 & 10500 & 0 & 0 & 63 & 27424 & 85 & 31567 & 19950 & 568400 & 148 & 20098 \\
\hline 28-Dec & 1700 & 30 & 50410 & 354.9 & 2100 & 1000 & 95 & 2100 & 0 & 14000 & 1750 & 257 & 27681 & 218 & 31785 & 17850 & 586250 & 475 & 18325 \\
\hline 29-Dec & 1790 & 0 & 52200 & 354.9 & 2000 & 1005 & 96 & 3150 & 0 & 19600 & 0 & 393 & 28074 & 350 & 32135 & 22750 & 609000 & 743 & 23493 \\
\hline 30-Dec & 1740 & 8.8 & 53940 & 363.7 & 600 & 1038 & 95 & 3150 & 0 & 16800 & 0 & 352 & 28426 & 359 & 32494 & 19950 & 628950 & 711 & 20661 \\
\hline 31-Dec & 1440 & 10 & 55380 & 373.7 & 600 & 874 & 95 & 1050 & 0 & 8400 & 7000 & 1090 & 29516 & 1028 & 33522 & 16450 & 645400 & 2118 & 18568 \\
\hline$\%$ WIND & TURB & INE KI & WH PRC & ODUCE & TO TC & L GRID & & & & & & & & & & & & & $8.90 \%$ \\
\hline FUEL S & AVINGS & $S$ BY & WIND T & URBIN & OPER & IONS II & N GA & LONS & VOIDED & 100 & ED) & & & & & & & & 5409 \\
\hline
\end{tabular}

12-Dec-98 Production.xls

12-05-98 Wind Turbines off line $\sim 8$ hours - Pwr Plant Grid Failure 12-05, 12-06 Computer Display Problem 
JANUARY 1999

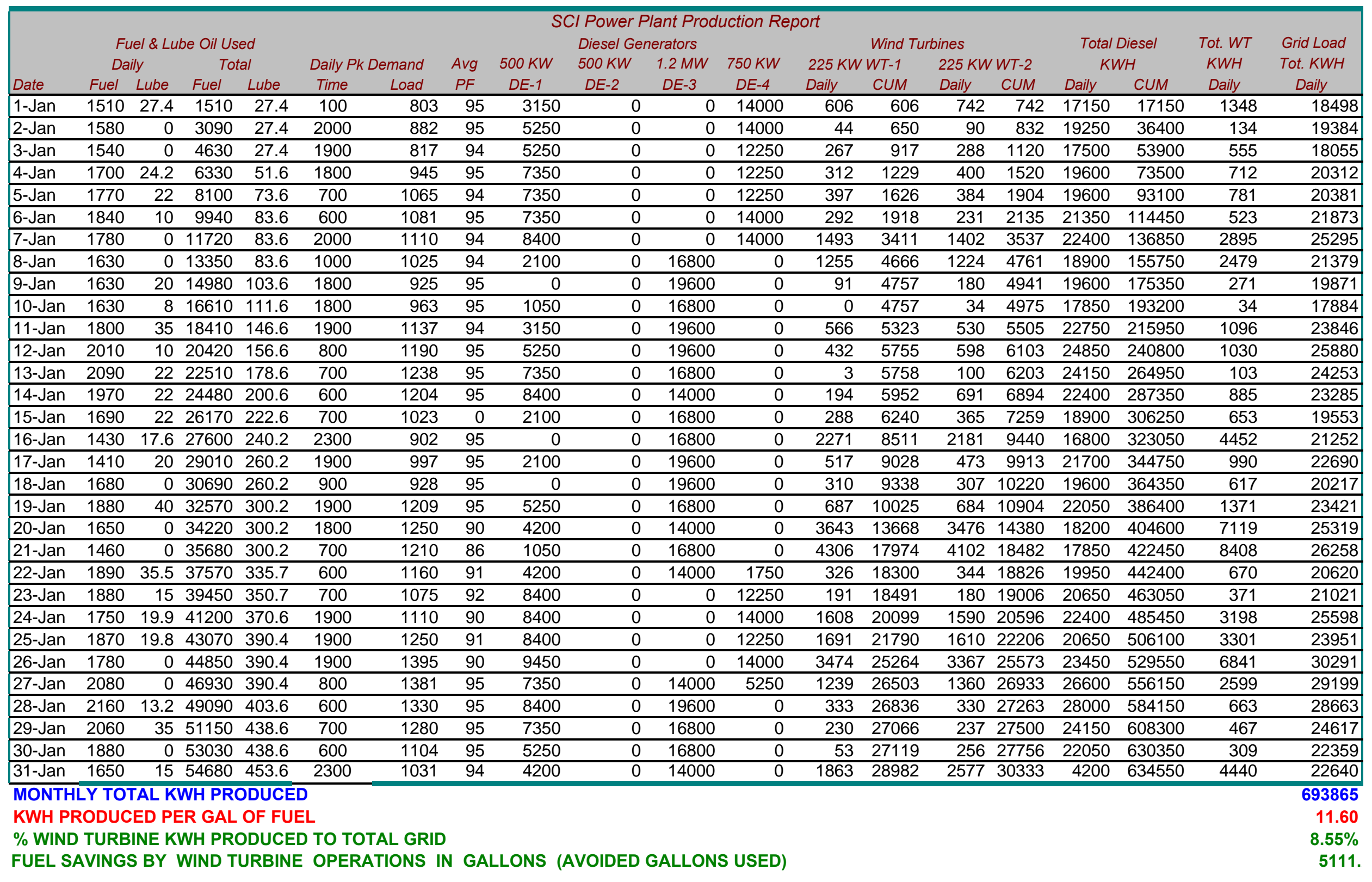

01-Jan-99.xls 
FEBRUARY 1999

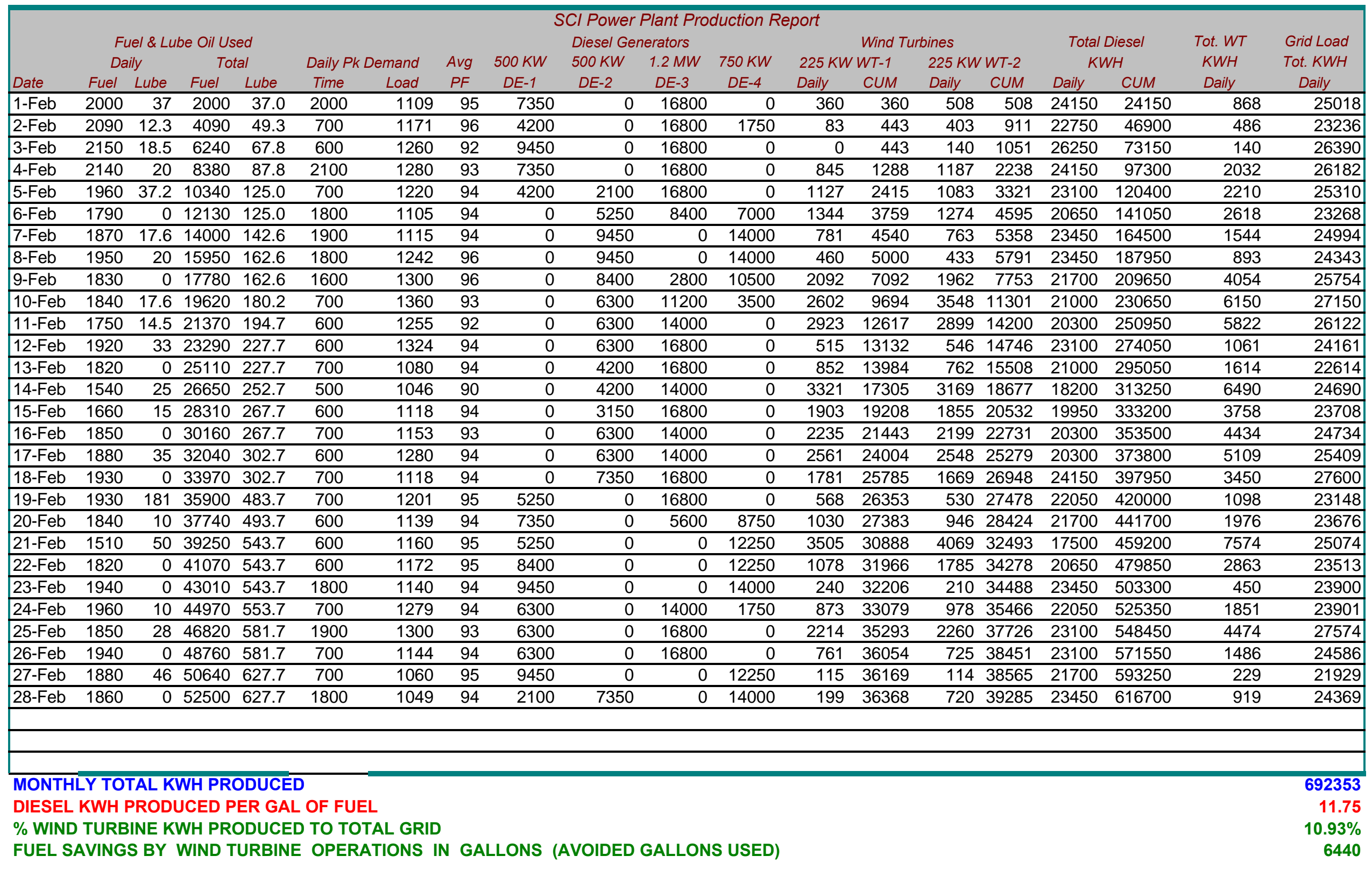

02-Feb-99.xls 


\section{MARCH 1999}

\begin{tabular}{|c|c|c|c|c|c|c|c|c|c|c|c|c|c|c|c|c|c|c|c|}
\hline & & & & & & & & & Cl Power & Plant Proc & duction $R \in$ & port & & & & & & & \\
\hline & & \& \& Lu & ube Oil Us & & & & & & Diesel Ger & nerators & & & Wind Tu & bines & & Total & Diesel & Tot. WT & Grid Load \\
\hline & Dai & & Tot & & Daily $P$ & emand & Avg & $500 \mathrm{KW}$ & $500 \mathrm{KW}$ & $1.2 \mathrm{MW}$ & $750 \mathrm{KW}$ & $225 \mathrm{KW}$ & $W T-1$ & $225 \mathrm{Kn}$ & $V W T-2$ & $K V$ & & $K W H$ & Tot. KWH \\
\hline Date & Fuel & Lube & Fuel & Lube & Time & Load & PF & $D E-1$ & $D E-2$ & $D E-3$ & $D E-4$ & Daily & CUM & Daily & CUM & Daily & CUM & Daily & Daily \\
\hline 1-Mar & 1780 & 0 & 1780 & 0.0 & 2300 & 1139 & 93 & 0 & 7350 & 0 & 12250 & 995 & 995 & 1204 & 1204 & 19600 & 19600 & 2199 & 21799 \\
\hline 2-Mar & 1830 & 0 & 3610 & 0.0 & 2000 & 1181 & 92 & 1050 & 7350 & 0 & 12250 & 1892 & 2887 & 1770 & 2974 & 20650 & 40250 & 3662 & 24312 \\
\hline 3-Mar & 1710 & 0 & 5320 & 0.0 & 600 & 1254 & 94 & 0 & 7350 & 2800 & 10500 & 3385 & 6272 & 3355 & 6329 & 20650 & 60900 & 6740 & 27390 \\
\hline 4-Mar & 1760 & 0 & 7080 & 0.0 & 700 & 1305 & 94 & 4200 & 0 & 16800 & 0 & 2633 & 8905 & 2536 & 8865 & 21000 & 81900 & 5169 & 26169 \\
\hline 5-Mar & 2090 & 17 & 9170 & 17.0 & 700 & 1211 & 95 & 7350 & 0 & 16800 & 0 & 2 & 8907 & 56 & 8921 & 24150 & 106050 & 58 & 24208 \\
\hline 6-Mar & 2110 & 0 & 11280 & 17.0 & 2000 & 1203 & 94 & 9450 & 0 & 2800 & 12250 & 211 & 9118 & 240 & 9161 & 24500 & 130550 & 451 & 24951 \\
\hline 7-Mar & 1860 & 0 & 13140 & 17.0 & 1900 & 1265 & 94 & 9450 & 0 & 2800 & 12250 & 1014 & 10132 & 2126 & 11287 & 24500 & 155050 & 3140 & 27640 \\
\hline 8-Mar & 1940 & 20 & 15080 & 37.0 & 2100 & 1215 & 95 & 8400 & 0 & 11200 & 3500 & 1312 & 11444 & 1313 & 12600 & 23100 & 178150 & 2625 & 25725 \\
\hline 9-Mar & 2020 & 20 & 17100 & 57.0 & 1900 & 1352 & 94 & 8400 & 0 & 19600 & 0 & 1174 & 12618 & 1352 & 13952 & 28000 & 206150 & 2526 & 30526 \\
\hline 10-Mar & 1950 & 0 & 19050 & 57.0 & 1900 & 1382 & 91 & 8400 & 0 & 16800 & 0 & 2888 & 15506 & 2896 & 16848 & 25200 & 231350 & 5784 & 30984 \\
\hline 11-Mar & 2030 & 55 & 21080 & 112.0 & 800 & 1395 & 91 & 7350 & 0 & 16800 & 0 & 1595 & 17101 & 1883 & 18731 & 24150 & 255500 & 3478 & 27628 \\
\hline 12-Mar & 1890 & 0 & 22970 & 112.0 & 500 & 1211 & 93 & 4200 & 0 & 19600 & 0 & 367 & 17468 & 362 & 19093 & 23800 & 279300 & 729 & 24529 \\
\hline 13-Mar & 1830 & 0 & 24800 & 112.0 & 2000 & 1070 & 94 & 3150 & 0 & 16800 & 0 & 375 & 17843 & 358 & 19451 & 19950 & 299250 & 733 & 20683 \\
\hline 14-Mar & 1920 & 22 & 26720 & 134.0 & 2000 & 1069 & 94 & 7350 & 0 & 16800 & 0 & 410 & 18253 & 421 & 19872 & 24150 & 323400 & 831 & 24981 \\
\hline 15-Mar & 1840 & 22 & 28560 & 156.0 & 1100 & 1296 & 94 & 7350 & 0 & 14000 & 0 & 1827 & 20080 & 1884 & 21756 & 21350 & 344750 & 3711 & 25061 \\
\hline 16-Mar & 1970 & 0 & 30530 & 156.0 & 600 & 1146 & 96 & 9450 & 0 & 14000 & 0 & 424 & 20504 & 622 & 22378 & 23450 & 368200 & 1046 & 24496 \\
\hline 17-Mar & 2290 & 40 & 32820 & 196.0 & 1900 & 1228 & 96 & 9450 & 0 & 16800 & 0 & 181 & 20685 & 346 & 22724 & 26250 & 394450 & 527 & 26777 \\
\hline 18-Mar & 2180 & 18 & 35000 & 214.0 & 2200 & 1205 & 96 & 7350 & 3150 & 16800 & 0 & 100 & 20785 & 123 & 22847 & 27300 & 421750 & 223 & 27523 \\
\hline 19-Mar & 1980 & 13 & 36980 & 227.0 & 700 & 1151 & 96 & 0 & 8400 & 8400 & 5250 & 456 & 21241 & 656 & 23503 & 22050 & 443800 & 1112 & 23162 \\
\hline 20-Mar & 1890 & 0 & 38870 & 227.0 & 2100 & 1043 & 96 & 0 & 8400 & 0 & 14000 & 338 & 21579 & 398 & 23901 & 22400 & 466200 & 736 & 23136 \\
\hline 21-Mar & 1840 & 35 & 40710 & 262.0 & 700 & 1027 & 96 & 2100 & 7350 & 0 & 12250 & 1007 & 22586 & 1115 & 25016 & 21700 & 487900 & 2122 & 23822 \\
\hline 22-Mar & 2620 & 9 & 43330 & 271.0 & 600 & 1090 & 96 & 9450 & 0 & 0 & 10500 & 2189 & 24775 & 2354 & 27370 & 19950 & 507850 & 4543 & 24493 \\
\hline 23-Mar & 1920 & 22 & 45250 & 293.0 & 2000 & 1128 & 96 & 9450 & 0 & 5600 & 10500 & 1856 & 26631 & 1796 & 29166 & 25550 & 533400 & 3652 & 29202 \\
\hline 24-Mar & 2100 & 0 & 47350 & 293.0 & 600 & 1244 & 95 & 8400 & 0 & 16800 & 0 & 1234 & 27865 & 1302 & 30468 & 25200 & 558600 & 2536 & 27736 \\
\hline 25-Mar & 2180 & 13 & 49530 & 306.0 & 1200 & 1258 & 95 & 9450 & 0 & 16800 & 0 & 641 & 28506 & 1139 & 31607 & 26250 & 584850 & 1780 & 28030 \\
\hline 26-Mar & 1880 & 38 & 51410 & 344.0 & 2300 & 1114 & 94 & 6300 & 0 & 16800 & 0 & 1566 & 30072 & 1840 & 33447 & 23100 & 607950 & 3406 & 26506 \\
\hline 27-Mar & 1960 & 0 & 53370 & 344.0 & 600 & 1005 & 96 & 7350 & 0 & 14000 & 0 & 170 & 30242 & 163 & 33610 & 21350 & 629300 & 333 & 21683 \\
\hline 28-Mar & 1950 & 0 & 55320 & 344.0 & 600 & 1060 & 95 & 1050 & 8400 & 2800 & 8750 & 752 & 30994 & 675 & 34285 & 21000 & 650300 & 1427 & 22427 \\
\hline 29-Mar & 1930 & 0 & 57250 & 344.0 & 2100 & 1125 & 94 & 0 & 10500 & 0 & 14000 & 115 & 31109 & 138 & 34423 & 24500 & 674800 & 253 & 24753 \\
\hline 30-Mar & 1680 & 16 & 58930 & 360.0 & 800 & 996 & 93 & 0 & 8400 & 0 & 10500 & 3607 & 34716 & 3500 & 37923 & 18900 & 693700 & 7107 & 26007 \\
\hline 31-Mar & 1610 & 20 & 60540 & 380.0 & 900 & 1325 & 88 & 0 & 7350 & 0 & 10500 & 4989 & 39705 & 4942 & 42865 & 10500 & 704200 & 9931 & 27781 \\
\hline MONTH & LY TOT & AL KI & WH PRC & ODUCĒ & & & & & & & & & & & & & & & 786770 \\
\hline DIESEL & KWH P & RODL & UCED P & 'ER GAL & OF FL & & & & & & & & & & & & & & 11.63 \\
\hline$\%$ WIND & TURB & NE KI & WH PRC & ODUCE & D TO T & LL GRID & & & & & & & & & & & & & $10.49 \%$ \\
\hline FUEL S & AVINGS & BY & WIND T & FURBINE & & & & & & & & & & & & & & & 7099 \\
\hline
\end{tabular}


APRIL 1999

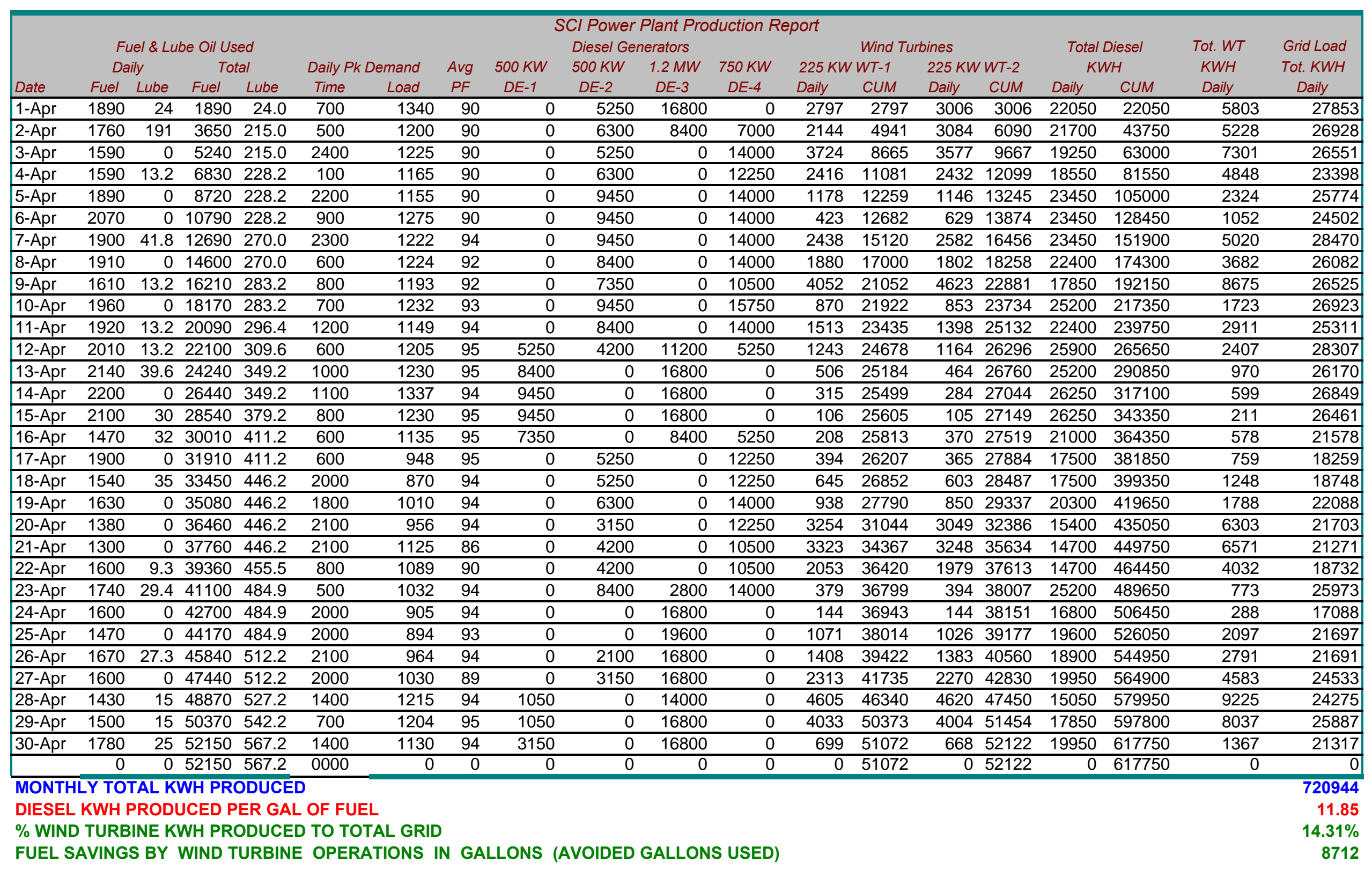




\section{May 1999}

\begin{tabular}{|c|c|c|c|c|c|c|c|c|c|c|c|c|c|c|c|c|c|c|c|}
\hline \multirow[b]{3}{*}{ Date } & \multicolumn{4}{|c|}{ Fuel \& Lube Oil Used } & & \multirow{3}{*}{$\begin{array}{l}\text { Avg } \\
\text { PF }\end{array}$} & \multirow{3}{*}{$\begin{array}{c}500 \mathrm{KW} \\
\mathrm{DE-1} \\
\end{array}$} & \multicolumn{3}{|c|}{ Diesel Generators } & \multicolumn{4}{|c|}{ Wind Turbines } & \multirow{2}{*}{\multicolumn{2}{|c|}{$\begin{array}{c}\text { Total Diesel } \\
\text { KWH }\end{array}$}} & \multirow{3}{*}{$\begin{array}{l}\text { Tot. WT } \\
\text { KWH } \\
\text { Daily }\end{array}$} & \multirow{3}{*}{$\begin{array}{l}\text { Grid Load } \\
\text { Tot. KWH } \\
\text { Daily }\end{array}$} \\
\hline & \multicolumn{2}{|c|}{ Daily } & \multicolumn{2}{|c|}{ Total } & & & & & \multirow{2}{*}{$\begin{array}{c}500 \mathrm{KW} \\
D E-2\end{array}$} & \multirow{2}{*}{$\begin{array}{c}1.2 \mathrm{MW} \\
D E-3 \\
\end{array}$} & \multirow{2}{*}{$\begin{array}{c}750 \mathrm{KW} \\
\mathrm{DE}-4 \\
\end{array}$} & \multicolumn{2}{|c|}{$225 K W W T-1$} & \multicolumn{2}{|c|}{$225 K W W T-2$} & & & & \\
\hline & Fuel & Lube & Fuel & Lube & Daily Pk Demand & Load & & & & & & Daily & CUM & Daily & CUM & Daily & CUM & & \\
\hline 1-May & 1730 & 30 & 1730 & 30.0 & 2100 & 1027 & 95 & 8400 & 0 & 0 & 10500 & 712 & 712 & 667 & 667 & 18900 & 18900 & 1379 & 20279 \\
\hline 2-May & 1520 & 0 & 3250 & 30.0 & 2000 & 1011 & 94 & 0 & 4200 & 0 & 12250 & 2413 & 3125 & 2366 & 3033 & 16450 & 35350 & 4779 & 21229 \\
\hline 3-May & 1350 & 10 & 4600 & 40.0 & 2000 & 1118 & 94 & 0 & 2100 & 0 & 14000 & 4331 & 7456 & 4309 & 7342 & 16100 & 51450 & 8640 & 24740 \\
\hline 4-May & 1610 & 5 & 6210 & 45.0 & 600 & 1125 & 95 & 0 & 5250 & 0 & 14000 & 2930 & 10386 & 2834 & 10176 & 19250 & 70700 & 5764 & 25014 \\
\hline 5-May & 2040 & 31.3 & 8250 & 76.3 & 800 & 1185 & 95 & 0 & 9450 & 0 & 15750 & 90 & 10476 & 97 & 10273 & 25200 & 95900 & 187 & 25387 \\
\hline 6-May & 1900 & 0 & 10150 & $\overline{76.3}$ & 1100 & 1051 & 95 & 0 & 7350 & 0 & 14000 & 453 & 10929 & 396 & 10669 & 21350 & 117250 & 849 & 22199 \\
\hline 7-May & 1630 & 14 & 11780 & 90.3 & 800 & 948 & 93 & 0 & 4200 & 8400 & 7000 & 1133 & 12062 & 1060 & 11729 & 19600 & 136850 & 2193 & 21793 \\
\hline 8-May & 1540 & 14 & 13320 & 104.3 & 1800 & 894 & 94 & 0 & 0 & 16800 & 0 & 679 & 12741 & 642 & 12371 & 16800 & 153650 & 1321 & 18121 \\
\hline 9-May & 1540 & 12.7 & 14860 & 117.0 & 1900 & 942 & 95 & 0 & 0 & 19600 & 0 & 511 & 13252 & 474 & 12845 & 19600 & 173250 & 985 & 20585 \\
\hline 10-May & 1660 & 18.9 & 16520 & 135.9 & 2000 & 952 & 94 & 0 & 0 & 19600 & 0 & 271 & 13523 & 264 & 13109 & 19600 & 192850 & 535 & 20135 \\
\hline 11-May & 1790 & 42 & 18310 & 177.9 & 2200 & 1002 & 95 & 7350 & 0 & 8400 & 8750 & 87 & 13610 & 76 & 13185 & 24500 & 217350 & 163 & 24663 \\
\hline 12-May & 1900 & 12 & 20210 & 189.9 & 1300 & 1021 & 95 & 7350 & 0 & 14000 & 0 & 256 & 13866 & 243 & 13428 & 21350 & 238700 & 499 & 21849 \\
\hline 13-May & 1900 & 0 & 22110 & 189.9 & 2300 & 987 & 95 & 8400 & 0 & 1400 & 0 & 102 & 13968 & 102 & 13530 & 9800 & 248500 & 204 & 10004 \\
\hline 14-May & 1600 & 31 & 23710 & 220.9 & 600 & 1035 & 95 & 4200 & 0 & 11200 & 0 & 1693 & 15661 & 1650 & 15180 & 15400 & 263900 & 3343 & 18743 \\
\hline 15-May & 1390 & 15 & 25100 & 235.9 & 700 & 865 & 95 & 0 & 3150 & 0 & 14000 & 2263 & 17924 & 2270 & 17450 & 17150 & 281050 & 4533 & 21683 \\
\hline 16-May & 1630 & 0 & 26730 & 235.9 & 900 & 890 & 95 & 0 & 3150 & 8400 & 8750 & 294 & 18218 & 273 & 17723 & 20300 & 301350 & 567 & 20867 \\
\hline 17-May & 1710 & 20 & 28440 & 255.9 & 700 & 948 & 95 & 1050 & 0 & 19600 & 0 & 70 & 18288 & 66 & 17789 & 20650 & 322000 & 136 & 20786 \\
\hline 18-May & 1710 & 18 & 30150 & 273.9 & 500 & 953 & 95 & 2100 & 0 & 16800 & 0 & 908 & 19196 & 849 & 18638 & 18900 & 340900 & 1757 & 20657 \\
\hline 19-May & 1480 & 20 & 31630 & 293.9 & 1000 & 980 & 94 & 1050 & 0 & 16800 & 0 & 2553 & 21749 & 2445 & 21083 & 17850 & 358750 & 4998 & 22848 \\
\hline 20-May & 1660 & 1.3 & 33290 & 295.2 & 600 & 920 & 94 & 0 & 5250 & 5600 & 10500 & 2123 & 23872 & 2071 & 23154 & 21350 & 380100 & 4194 & 25544 \\
\hline 21-May & 1930 & 10 & 35220 & 305.2 & 600 & 1101 & 95 & 0 & 9450 & 0 & 14000 & 64 & 23936 & 65 & 23219 & 23450 & 403550 & 129 & 23579 \\
\hline 22-May & 1860 & 0 & 37080 & 305.2 & 2200 & 1055 & 95 & 0 & 7350 & 0 & 14000 & 76 & 24012 & 71 & 23290 & 21350 & 424900 & 147 & 21497 \\
\hline 23-May & 1830 & 28 & 38910 & 333.2 & 600 & 1031 & 95 & 0 & 8400 & 0 & 14000 & 234 & 24246 & 212 & 23502 & 22400 & 447300 & 446 & 22846 \\
\hline 24-May & 1680 & 10 & 40590 & 343.2 & 2200 & 1005 & 95 & 0 & 7250 & 0 & 12250 & 1797 & 26043 & 1709 & 25211 & 19500 & 466800 & 3506 & 23006 \\
\hline 25-May & 1800 & 0 & 42390 & 343.2 & 600 & 1022 & 95 & 0 & 8400 & 0 & 12250 & 1163 & 27206 & 1085 & 26296 & 20650 & 487450 & 2248 & 22898 \\
\hline 26-May & 1920 & 18 & 44310 & 361.2 & 1200 & 1150 & 94 & 0 & 8400 & 0 & 14000 & 809 & 28015 & 766 & 27062 & 22400 & 509850 & 1575 & 23975 \\
\hline 27-May & 1800 & 26 & 46110 & 387.2 & 1900 & 1070 & 94 & 0 & 7350 & 0 & 14000 & 1024 & 29039 & 937 & 27999 & 21350 & 531200 & 1961 & 23311 \\
\hline 28-May & 1610 & 0 & 47720 & 387.2 & 700 & 1000 & 93 & 0 & 5250 & 8400 & 7000 & 1490 & 30529 & 1427 & 29426 & 20650 & 551850 & 2917 & 23567 \\
\hline 29-May & 1550 & 2 & 49270 & 389.2 & 2300 & 1035 & 93 & 0 & 0 & 16800 & 0 & 1590 & 32119 & 1541 & 30967 & 16800 & 568650 & 3131 & 19931 \\
\hline 30-May & 1560 & 28 & 50830 & 417.2 & 2100 & 970 & 93 & 0 & 0 & 19600 & 0 & 1268 & 33387 & 1197 & 32164 & 19600 & 588250 & 2465 & 22065 \\
\hline 31-May & 1540 & 0 & 52370 & 417.2 & 2200 & 905 & 93 & 0 & 0 & 16800 & 0 & 1032 & 34419 & 1016 & 33180 & 16800 & 605050 & 2048 & 18848 \\
\hline \multicolumn{12}{|c|}{ MONTHLY TOTAL KWH PRODUCED } & & & & & & & & 672649 \\
\hline DIESEL & KWH & RODL & UCED P & ER GA & OF FU & & & & & & & & & & & & & & 11.55 \\
\hline$\%$ WIND & TURB & INE KI & WH PRC & DDUCE & TO TC & - GRID & & & & & & & & & & & & & $10.05 \%$ \\
\hline FUEL S & AVING & 5 BY & WIND T & URBIN & OPEF & ONS If & $\mathbf{N}$ GA & LLONS & OIDED & ALLONS & S USED) & & & & & & & & 5851 \\
\hline
\end{tabular}




\section{APPENDIX C: \\ Independent Paper on Wind-Diesel Hybrid Energy System Design and Operation [6]}

This appendix was included to display some of the earlier design and operational strategy

developed by NREL and NREL sub-contractors for the remote wind-diesel system. 


\title{
The Evaluation of the Wind Resource at San Nicolas Island
}

\author{
Alan H. Miller \\ P.S.I. \\ Golden, Colorado
}

\section{Introduction}

One use of renewable energy in the near term is the addition of wind turbines on isolated, (non-intertied, non-gridconnected), electrical systems such as on small to moderately populated islands or in very remote, sparsely populated areas. Such systems are usually powered by diesel engines. While fairly large wind systems have been installed in diesel powered grids on several of the off-shore islands in Great Britain, and also on some islands off the coast of Norway, none in a class of systems comprising a megawatt or more has ever been installed in the United States, it's possessions or protectorates.

This report provides an assessment of the wind energy potential on one island owned by the U.S. Navy off the southwest coast of California. The wind energy atlases produced by the Pacific Northwest Laboratory and it's subcontractors over a decade ago, assessed the Channel Islands as having a class two wind resource - a rather low value. A more recent look and a number of qualitative indications gave rise to a program to collect some new wind data in an area appropriate for the installation of wind turbines on the island. This assessment makes use of that data. The assessment has been accomplished in a manner that went beyond the normal resource assessment in that it was done with the current diesel system in mind and in a manner not necessarily intended to maximize the wind energy capture but to integrate as much wind energy as possible without causing any significant disruption to the existing system other than to reduce it's costs and the effluent of pollutants. The system under study here is the U.S. Navy's San Nicolas Island, California. The secondary purpose of this report is to document the efficacy of a simple spreadsheet model to perform such resource assessments.

The report is comprised of nine sections. Immediately following this Introduction is a section on the Background and history of this assessment and model development task. This is immediately followed by a concise statement of the purpose of the project and the model. The fourth section elucidates the assumptions that had to be made in developing the model. While the terminology 'assumption' might elicit the thought that the model is somewhat subjective, the section includes justification for each and every assumption and the potential effect of the assumption.

A separate section on the existing power system on the island follows. Though it might well have been placed further forward in the Background section, it was placed where it is so that the technical background material included was in closer proximity to the remainder of the technical development of the system. The model, as will be explained later, was developed based on hourly average data. The description of the data and it's sources comprises the following section. Thereafter the reader will find the details of the development of the spreadsheet model which lacks a name since it is based on commercially available software.

When designing large machinery or complex systems, the ultimate driver for the project is typically, economics. The next section outlines the economics of the system. Obtaining many of the inputs to the economics was tenuous leading to the uneasy feeling that the numbers were something akin to a "guess". Some of the costs for the turbines is admittedly a guess based on some experience. In all cases, it is believed that the values used are at least conservative. The final two sections show the results of the modeling effort and what conclusions can be drawn from the results. Recommendations have not been included as that seemed inappropriate and self-serving at best. 


\section{Background}

Since 1994, the U.S. Navy, with the help of the National Renewable Energy Laboratory, (NREL) has been taking wind and related data on several of the Channel Islands off the coast of Southern California. The purpose of this effort was to evaluate the technical and economic potential of integrating wind energy into the diesel powered grid at a non-grid connected military installation. Further, wind energy needed to be evaluated as a means to both reduce the consumption of diesel fuel and abate the discharge of pollutants into the atmosphere. One of these island facilities among the Channel Island group, San Clemente Island, is moving ahead with the acquisition of wind turbines to integrate into the island power system. The island of interest in this report, however, is San Nicolas Island. While there is no immediate plan to incorporate wind energy on the island, there is a sufficient interest in wind energy to warrant performing this assessment and system operations modeling effort.

Several groups have moved in the direction of modeling wind/diesel systems in an effort to demonstrate the utility of adding wind to a diesel system. The number of diesel powered, islanded grids on the face of the earth probably approaches ten thousand. Not all of these have viable wind resources to draw on but many may. The great majority of these are probably systems with a maximum peak demand of less than $100 \mathrm{KW}$ - relatively small village communities. Some preliminary analyses of these smaller system leads to the conclusion that the most desirable system and end effect can only be attained if the diesel(s) can be totally shut off. For small systems that can afford some small amount of battery or other storage, this is probably true. In a system comprising a $1000 \mathrm{~kW}$ or more, the addition of multi-MWh capacity batteries is 1) too expensive and 2) extremely maintenance intensive and, 3) an environmental hazard. Therefore, battery storage was not included in the scenario.

One high resolution, wind/diesel model, HYBRID2, is a simulation model with many diverse attributes. It has the capability to simulate minute by minute operations of a wind/hybrid/diesel system that can include storage and any or all of a number of prominent renewable technologies. It was developed by the University of Massachusetts in conjunction with NREL and sponsored by the U. S. Department of Energy. HYBRID2 may well be the epitome of hybrid energy system models with multiple resource modeling capability. However, for cases where only hourly wind and load data are available, a sophisticated model such as this are not justified. Models of this nature may be an expert tool to help define and describe an optimum operating strategy and even to specify optimal component sizes but are not practical tools for looking at low resolution, resource assessment type data.

\section{Purpose}

The purpose of this report, as stated previously, is two-fold. The first and most important is to provide an assessment of the wind resource at San Nicolas and the potential interactions of wind turbines with the diesel system. The second is to document the development and operation of a simple model of a wind/diesel system based on a MicroSoft Excel ${ }^{\Phi}$ Spread Sheet. It should be pointed out that developing a "model" per se, was not in the definition of the task. The resulting model, while being fairly versatile, is not a model in the true sense of the term but could be converted easily enough.

The data used in this analysis was also run in the HYBRID2 model and results were obtained by another investigator. At the time this work is being done, the HYBRID2 model had not been fully validated and for the simulation run, the model was apparently allowed to specify the operating strategy of the diesel system including picking the optimum engine(s) to have on line as well as total engine shutdown. While this is an ideal operating situation, it is unrealistic in the example. A simple spread sheet model has the advantage of being as flexible and/or as complex as one is willing to program it.

\section{Assumptions in the Spreadsheet Model}

While the author, a long time advocate of wind energy, would hope that the results of any model would work to the utmost advantage of wind energy, the task of assessing the value of the resource with the spreadsheet model has been carried out very conservatively. The data handling techniques and the modeling development have all been accomplished with a conservative bent. The idea was to "let the chips fall where they may". None of the data was modified in any way other than to move a portion of one set as explained below. No exponent was applied to the 
wind speed data nor was their any atmospheric density correction. Since the altitude of the site is only about $700 \mathrm{ft}$, a density correction would only amount to a factor of about .05

In the modeling and assessment effort, the load and wind data were used as provided. No finer scale data was available to develop power spectral density functions of within-hour load or wind speed variances. As noted above no shear exponent was applied which should have evidenced an increase in wind speeds generally whereas the small density correction would have worked the other direction essentially nullifying the shear induced increase. Since the wind input data is averaged over hourly periods, the subsequent convolution of the wind turbine generator power curve with the hourly average wind data should produce a reasonably conservative estimate of the energy produced. This is due to the fact that while the averaging process is linear, the power available in the wind follows the equation:

$$
\mathrm{P}=1 / 2 \rho \mathrm{AV}^{3}
$$

where $\mathrm{P}=$ available power in the wind, $\rho=$ atmospheric density, and $\mathrm{V}=$ the wind speed, and the curve fit to the wind includes a cubic function thereby producing the under-estimates.

Wind resource data is usually analyzed and condensed into a convenient characteristic distribution such as the two parameter Weibull or the simpler, single parameter Rayleigh distribution in which the $\mathrm{K}$ (shape) parameter is set constant at 2. The concept of fitting a Weibull or Rayleigh distribution function to annual hourly averaged wind data and convoluting the fit with the power curve of a specific wind turbine to ascribe an estimated annual energy capture was successfully challenged over a decade ago. With the large, multi-megawatt wind turbines such as the MOD-1 and MOD-2 that were under development at the time, there was concern that the time derivatives in the operating strategy weren't being adequately represented. Such methods of estimating annual energy capture did prove to be significantly in error (over-estimates).

As mentioned earlier, the HYBRID2 model was apparently allowed to dictate the operating strategy of the diesel power plant. The spread sheet model also applied certain constraints. The only constraint on the diesel system was to set the minimum allowable load remaining on the system for the diesel plant to pick up. For the current presentation, the lower limit was set at $200 \mathrm{KW}$ minimum load. (A second iteration with the minimum set at $100 \mathrm{KW}$ was also run). This was based on the fact that wind turbines incorporating induction generators require some system load to work into or the system voltage and frequency become unstable. Obviously, induction machines also require field magnetization current from the line By setting this constraint it is felt one can maintain system stability (frequency and voltage) and reliability. The number, $200 \mathrm{KW}$, could as well have been 100 or 500 .

\section{The San Nicolas power system}

The array of diesel engines that are available to serve load on San Nicolas Island include two Caterpillar diesels with a capacity of $750 \mathrm{KW}$ each and three EMD diesels with capacities of $500 \mathrm{KW}(2)$ and $1000 \mathrm{KW}(1)$. In a typical large utility operation, pairs of engines would be operated such that either one could pick up the entire expected load should the other engine fail or trip off line for some untoward reason. It is not known if the power plant on San Nicolas is equipped with Woodward Governors and Load Share devices like San Clemente's powerhouse is, but it is presumed they are. The incorporation of this apparatus makes the operation of the diesel plant fairly simple and manages whatever engines are on line.

Frequently, people apply a "rule of thumb" that a diesel generator should never be run below the $40 \%$ load level. The author's experience with large (megawatt and larger) diesels suggested that this was quite possibly hyperbole rather than fact. The Electro-Motive Division (EMD) of Detroit Diesel in LaGrange, Illinois, was contacted to determine the minimum operating conditions for EMD engines. The engineering department indicated that as long as the engines were loaded to a higher level - say $60-80 \%$ of rated - for a while before being shut off, there was no problem running them at $10 \%$ load, for many hours. They pointed out that railroad locomotives are commonly left running at idle for entire weekends. It has also been pointed out that maintaining engine temperature is mandatory and in these large, sub- and multi-megawatt stationary engines, circulation of coolant and the maintenance of temperature is quite easy and usually accomplished with electrically operated, proportional controllers rather than mechanical thermostats. 
A significant factor in the philosophy of the spread sheet model is related to human engineering. The Navy's interest is also in maintaining system reliability - that is, a minimum of potential system outages. The typical utility system operating strategy would operate with two engines on line and the load, assuming the presence of LoadShare devices, would be proportionally split. For instance, with the $750 \mathrm{KW}$ and a $500 \mathrm{KW}$ diesel running, the $750 \mathrm{KW}$ engine would be called upon to provide about $60 \%$ of the total load and the $500 \mathrm{KW}$ engine would provide the remaining $40 \%$. The combination of diesels that the operators put on line at San Clemente is a function of the anticipated loads. For example, in the middle of the night with minimum load and no expected operational or abnormal load increases, the load is usually only about $450 \mathrm{~kW}$. Under these circumstances the operators would likely have two $500 \mathrm{~kW}$ generators on line. Each would be running at about $50 \%$ load on average with no wind energy installed. In reality, on both islands, the operators are familiar and comfortable with their systems that they frequently operate with only one engine running at any time.

If significant wind energy was added to the system there is a finite possibility that more wind energy would be available than needed. With the addition of as many as four $225 \mathrm{~kW}$ rated wind turbines there is a very good possibility that the island might experience sufficient wind for the wind turbines to be generating their rated power of $225 \mathrm{~kW}$. Obviously, with two or more turbines running and the system load at it's minimum, $(\sim 50 \mathrm{~kW})$ the system would be unstable. By constraining the wind turbines to only make up the difference between a minimum set point, say $200 \mathrm{~kW}$, and the total load, we might be left with only one wind turbine operating (depending on load) but the operating diesel(s) running at a $450 \mathrm{~kW}$ or a little over $100 \mathrm{~kW}$ each if the pair were running (about $20 \%$ load), well within the safe operating envelope. Obviously, with this sort of operating strategy the system is not minimizing the amount of diesel fuel used but by doing so we have maintained system stability and reliability and the operators are confident that their system will handle the load without interruption. As will be seen later, even with this less than maximum incorporation and utilization of wind, the economics of the entire system appear to be good.

\section{The Data}

The San Nicolas Island wind data is hourly average data. The data were collected on a tower located in reasonable proximity to the area available for wind turbine installation. The data were collected at the 30.5 meter (100') level, a reasonable approximation to the likely hub height for modern wind turbines. The units of measure are meters/second. They are averaged from 10 -minute averages. No other sample statistics such as the hourly standard deviation, skewness or kurtosis were available to the author.

The hourly system load data in kilowatts, was transcribed from the operators hand written records to a spread sheet and represent, at least crudely, the operators best guess or "eyeball average" load for the hour. While this is not a terribly satisfying source for such data, looking at daily, weekly and monthly time series plots of the data does not reveal any obvious anomalies in the load and is acceptable for the purposes of this report.

The two data sets were not for synonymous periods of time but had 10 months overlap on an annual basis. The wind data collection began on August 1, 1994 and ran for a year while the load data were for the year October 1, 1989 through September, 1990. Since the model is meant to be "representative" of any year, it was decided to shift the load data to mate August and September 1990 loads to the August and September 1994 wind data. It has been pointed out that some form of newer load data is available that indicates an annual increase in load and the suggestion was made that an across-the-board increase be applied to the data but the author has chosen not to do that for a number of reasons.

Table 1. The load and wind data overlap. The Aug/Sept Load data were cut and pasted on to the front of the load file.

\begin{tabular}{|llllllllllllllll}
\hline Load & 1989 & & & Oct & Nov & Dec & Jan & Feb & Mar & Apr & May & Jun & Jul & Aug & Sept \\
Wind & 1994 & Aug & Sept & Oct & Nov & Dec & Jan & Feb & Mar & Apr & May & Jun & Jul & & \\
\hline
\end{tabular}

To represent the wind turbine, the power curve for a current model, $225 \mathrm{KW}$ rated wind turbine was used. The manufacturers literature included a 23 point tabulation of the wind speed vs. power output. This data was truncated at the $18 \mathrm{~meter} / \mathrm{second}$ inflection point in the curve and a polynomial fit was developed. Second, third, fourth and fifth order fits were then calculated with the results shown in table 2 
Table 2 Results of fitting the Micon power curve data to a polynomial curve of several orders.

\begin{tabular}{|c|c|c|}
\hline Order of Fit & Residual Variance & Coef. Of Determination $\left(\mathrm{R}^{2}\right)$ \\
\hline 2 & 232.28 & .9743 \\
\hline 3 & 49.28 & .9949 \\
\hline 4 & 9.56 & .9991 \\
\hline 5 & 8.68 & .9993 \\
\hline
\end{tabular}

The fourth order was chosen since the residual variance was not reduced significantly by going to the fifth order and coefficient of determination (goodness of fit) was insignificantly better at the fifth order than for the fourth order fit. The power curve when fit with the fourth order polynomial along with the original power curve provided by the manufacturer is shown in Figure 1 below.

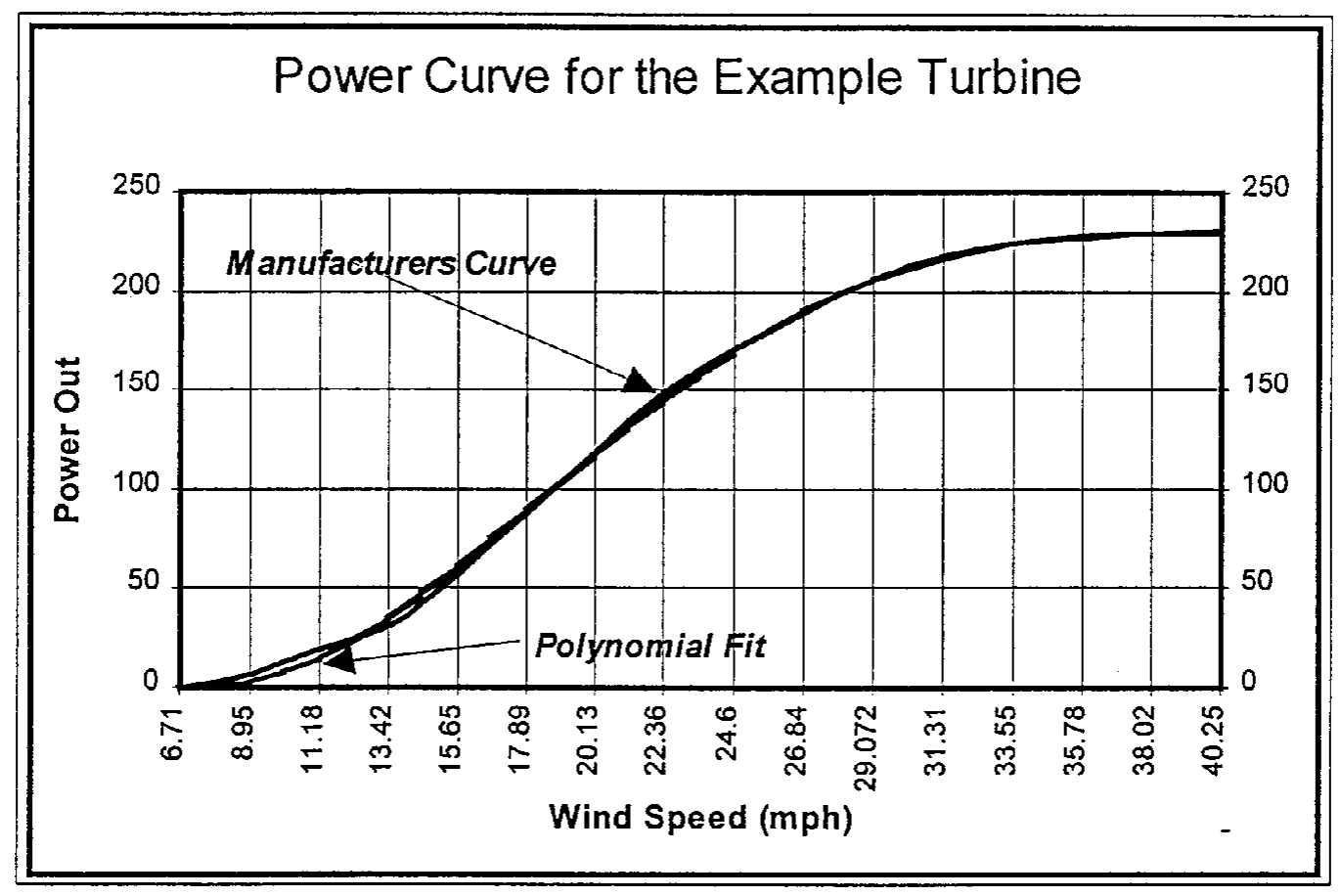

Figure 1. The Manufacturers power curve (the thin, dark, smooth line) and the $4^{\text {th }}$ order polynomial fit to the tabulated data (the thick, gray, jagged line).

\section{The Model}

The model was developed in a Microsoft Excel ${ }^{\circledR}$ format. The spreadsheet was set up in it's simplest form with the columns assigned as shown in Table 2 below. While it is possible to have a model such as this run totally externally to the data, the task was not to develop such a model but simply to derive the assessment data.

The first two columns are self explanatory. They simply provide the identifying date and time stamp. The third column is the hourly averaged wind speed data. This data was originally in units of meters/sec but was converted to miles/hour for the convenience of the reader. Column four is the equivalent (time stamped) system load data and constitutes the data that was edited to place the last two months of data (August and September, '90) at the beginning of the file.

This was done in case there was any seasonal component to the annual load or wind profile. Column five is the equivalent wind power out of one example turbine. It is calculated by taking the wind speed data in column three and convoluting it with the fourth order polynomial to the WTG power curve. 
The sixth column simply eliminates all WTG power out data below the $5.1 \mathrm{~kW}$ threshold. Here again, the value of 5.1 could have as easily been 10.1 . It was intended to eliminate the questionably low output energy levels. Typically, with the lower wind speeds, the within hour variance is likely to have been high. Therefore, while the average may have been 5.1, there is a high probability that the wind turbine would never have started up because it was not at that speed for long enough uninterrupted periods. The energy contribution, or loss in this case, is so small as to be insignificant.

The seventh, ninth, eleventh and thirteenth columns are written to determine if the addition of one, two, three, or four wind turbines at that output level would reduce the load remaining at the power house to below the minimum set point of $200 \mathrm{KW}$. If the test turns out negative, (the addition of the turbine will not reduce the balance of load on the diesels below the minimum), then the flag in the following column is set to a "1" (turbine allowed to operate). If the addition of that turbine would reduce the load on the diesels below the set point limit, then the flag is set to a " 0 " (the turbine is not allowed to operate). The leading and intervening columns, numbers six, eight, ten, and twelve are the power available with one, two, three, or four turbines in operation. The $14^{\text {th }}$ and $15^{\text {th }}$ columns simply sum the number of " $1 \mathrm{~s}$ " in "flag" columns seven, nine, eleven, and thirteen and the total wind power that can be utilized under the minimum set point constraint. The value in column 16 is the number representing the wind turbine power available that is not being utilized (the waste wind energy). Column 17 is the balance of load to be picked up by the diesels and column 18 is the equivalent fuel usage by the diesels. This last value was generated assuming a $13 \mathrm{kWh}$ gallon $^{-1}$ rate.

Table 2. Layout of the spread sheet columns.

\begin{tabular}{|l|l|}
\hline \multicolumn{2}{|l|}{ Column Number } \\
\hline 1 & Julian day \\
\hline 2 & Hour \\
\hline 3 & Wind Speed Average (mph)* \\
\hline 4 & System Load (kW) \\
\hline 5 & Power out of one WTG $(\mathrm{kW}$ unconstrained) \\
\hline 6 & Power out of first WTG $\left(\mathrm{kW}\right.$ constrained $\left.{ }^{* *}\right)$ \\
\hline 7 & Test \#1 for Excess Power \\
\hline 8 & Power out of second WTG (kW constrained $\left.{ }^{* *}\right)$ \\
\hline 9 & Test \#2 for Excess Power \\
\hline 10 & Power out of third WTG (kW constrained $\left.{ }^{* *}\right)$ \\
\hline 11 & Test \#3 for Excess Power \\
\hline 12 & Power out of fourth WTG (kW constrained $\left.{ }^{* *}\right)$ \\
\hline 13 & Test \#4 for Excess Power \\
\hline 14 & Total wind energy allowed on line (kW) \\
\hline 15 & Number of turbines on line \\
\hline 16 & Waste Wind Energy (kWh not generated due to curtailment of some number of WTGs) \\
\hline 17 & Diesel load balance (kW load remaining for the diesels to generate) \\
\hline 18 & Diesel fuel consumed (gal) at $13 \mathrm{kWh}$ gal ${ }^{-1}$ \\
\hline
\end{tabular}

* The wind speed data was converted from $\mathrm{m} / \mathrm{s}$ to $\mathrm{mph}$ for the convenience of the reader that may have no concept of speeds in meters per second.

** The only WTG constraint was simply to set the output of the turbine to zero if the

turbine output was below $5 \mathrm{~kW}$ since the reliability of such a calculation is somewhat questionable

Considerable work has been done to characterize the rate of fuel consumption by diesel engines compared to the percent load on the engine. The results indicate a nearly linear fit with approximately a $25 \%$ offset at zero load is appropriate. The operating generator(s) on the islands are never operated below synchronous speed except if they have been taken off line, then they are shut down completely.

The use of the Skarstein-Uhlen equation to accumulate fuel use is justified for high temporal resolution models. However, it is the authors opinion that with only hourly sampled load data, applying such an equation is meaningless. Experience with modern, large, low to intermediate speed, stationary diesels shows that the upper end of the 
efficiency spectrum might show as much as $15-17 \mathrm{kWh} \mathrm{gal}^{-1}$ fuel rate. A record of the fuel utilization on the island was available. The data was in Excel ${ }^{\star}$ format and gave the date, the daily energy generated/used in $\mathrm{kWh}$, the engine hours, and the fuel used. When expressed in terms of $\mathrm{kWh} \mathrm{gal}^{-1}$, the annual mean value is $11.6 \mathrm{kWh} \mathrm{gal}^{-1}$. Further investigation of the fuel use data seemed to be an exercise in futility. The understanding is that 24 engine hours indicates that at no time was there more than one engine on line. Any higher number indicates that for some portion of the day a number of diesels were running and on line. A multivariate analysis of the available data did not help clear up the picture. The relationship of engine hours, to $\mathrm{kWh}$, to gallons of fuel used over the entire year, was uncorrelated. While one could choose to use the $11.6 \mathrm{kWh}$ gal number as the average, the decision was made to use the number $13 \mathrm{kWh} \mathrm{gal}^{-1}$, a more typical value for similar operations familiar to the author. If in fact the real values are lower, such as $11 \mathrm{kWh} \mathrm{gal}^{-1}$, then the value of wind to the system is even greater.

It is important to realize that, though one might expect to see a $200 \mathrm{~kW}$ diesel load occur frequently in column 17 in this example, the $200 \mathrm{~kW}$ minimum constraint will not allow the addition of another WTG if that addition would reduce the diesel load below the $200 \mathrm{~kW}$ set point (limit). Therefore, the number in column 17 will always be between $200 \mathrm{~kW}$ and $425 \mathrm{kw}$ unless there is no wind power available. It must also be kept in mind that this entire model is based on hourly averaged data. In reality, there is little relationship between these apparent ramp rates with the actual ramp rates. One aspect of the control algorithm that was not incorporated into the present model but was "tested" for specific instances is the appropriate addition of load. The appropriate addition of load would occur when the disparity between the minimum set point and balance of diesel load were such that adding some load would allow another wind turbine to come on line thereby reducing the diesel load back to it's set point.

For example; assume that the wind is such that the example wind turbines would be putting out about $200 \mathrm{~kW}$; and the system load balance (after reduction by the wind) is $300 \mathrm{~kW}$. The addition of another turbine would reduce the load balance to be picked up by the diesel to $\sim 100 \mathrm{~kW}$ - below the minimum set point assumed to be $200 \mathrm{~kW}$. Now, if the control strategy added $\sim 100 \mathrm{~kW}$ of load to the system, the load balance would be increased to $400 \mathrm{~kW}$ thus allowing the addition of another wind turbine while reducing the balance of load on the diesel(s) to $200 \mathrm{~kW}$ (from $300 \mathrm{~kW}$ ), a reduction of $100 \mathrm{~kW}$ load and $\sim 8$ gallons of fuel based on hourly averages.

Figure 2 shows one of the model results for a six day period at the beginning of the file. The purpose of the figure is to show how the combination of wind and load governs the operation (on/off) of each of the four wind turbines. While Figure 2 provides a graphical representation of the operation of the wind turbines, the amount of wind energy that is being used is not indicated and the explanation of some of the operations is, thus, obscured. To provide some enlightenment, Figure 3 furnishes a time series chart depicting both the wind energy being used (bottom line bounding the shaded area) in the system and the total system load (top line bounding the shaded area).

The wind energy used (from column 14 of the spread sheet) is not necessarily the wind energy available. There are exceptions such as in cases where the bottom line on the chart goes to zero when there is more than $200 \mathrm{~kW}$ load. To help clarify the content of Figures 2 and 3 , the reader is asked to look at the region of each chart on late Julian day 213 and early day 214 . There is a period of about ten hours on both charts that appear as a relatively flat floored valley. In Figure 2, the period shows that only one turbine was in operation during the interval. During that same period on Figure 3, it is evident that the single turbine was producing around it's rated power of $225 \mathrm{~kW}$. If the operating strategy allowed a second turbine to come on line, the balance of load remaining for the diesel(s) to pick up would have been less than $100 \mathrm{~kW}$. Therefore, the test for excess power for the second turbine was positive and a second turbine was not allowed to come on line. 


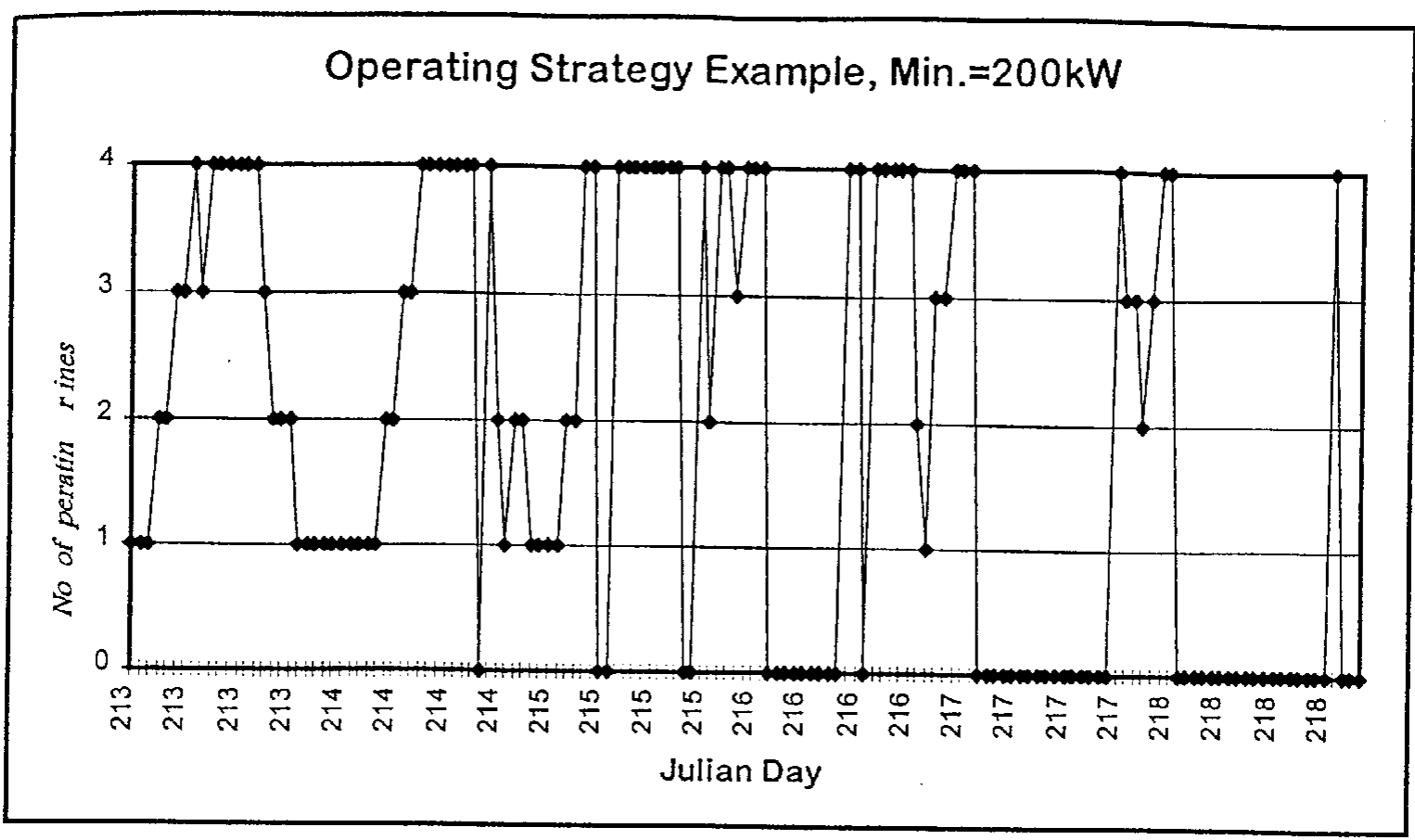

Figure 2. Chart showing the number of wind turbines operating during each hour for a six day period in early August. Each diannond represents an hour. The numbers on the abscissa are the Julian Day and are repeated every four hours. This chart does not provide any indication of the wind energy utilization.

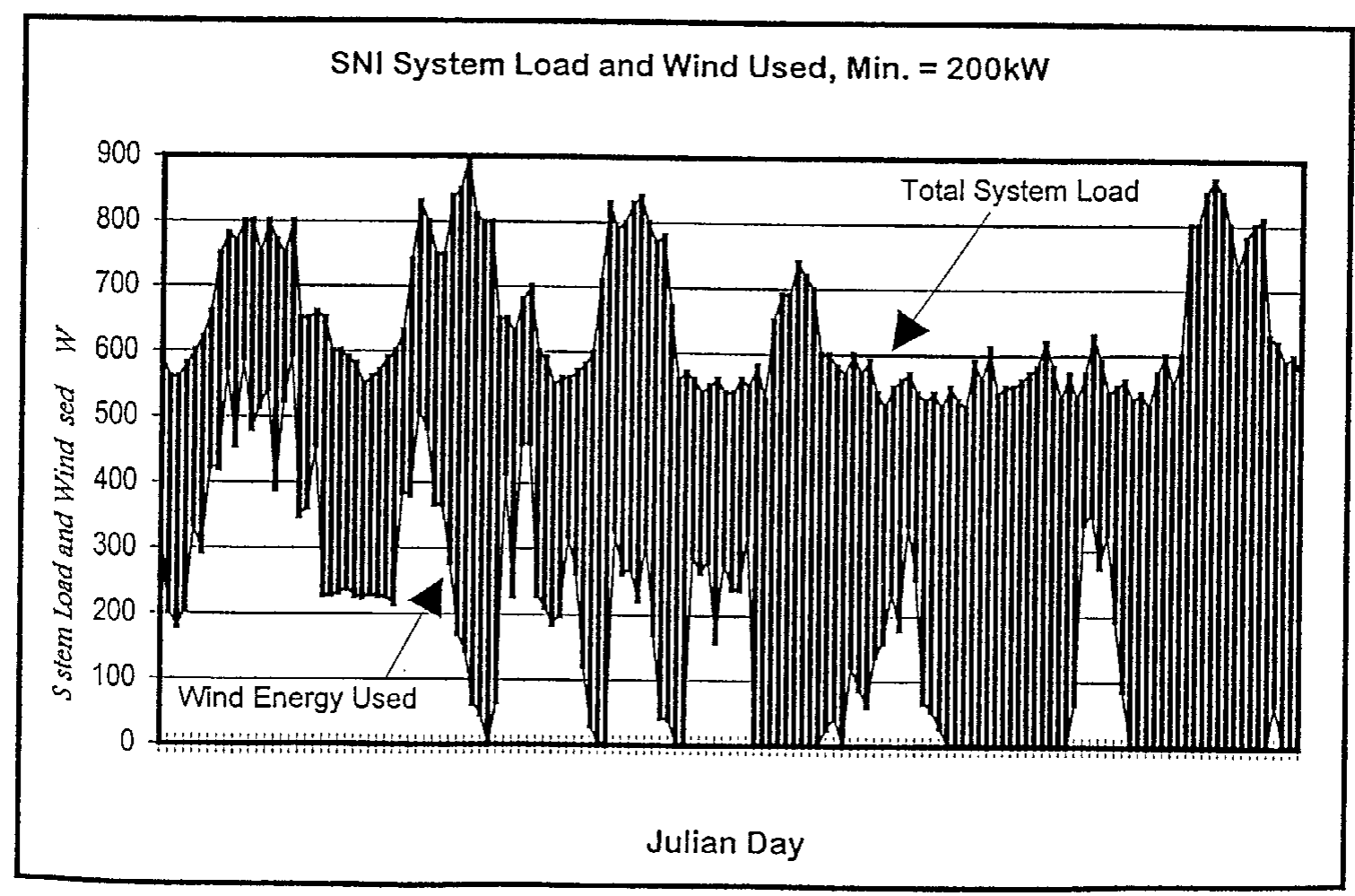

Figure 3. A time series plot of the total system load (top line) and the wind energy being used by the system (bottom line) during the same period. The area in the chart that is darkened is the portion of the load that the diesel generators would have to pick up and the clear area from the $x$-axis to the darkened area constitutes the load picked up by the wind turbines. 
Figures 4 and 5, below, are added to show the effect of changing the minimum set point to $100 \mathrm{~kW}$. Figure 4 shows that the number of hours during the period when only one turbine was running under the $200 \mathrm{~kW}$ set point have been significantly reduced with the lower set point. Note also in Figure 5, that the broad, flat floored valley during late day 213 and early day 214 has become a single hour that the diesels will have to pick up. For clarity, Figure 6 shows what the wind speed was doing during the same period. As can be seen, when there are zero wind turbines operating in both Figures 2 and 4, it is not because of low loads but rather low to no wind. Recall that the power out of the wind turbine below about 10 miles per hour is nil.

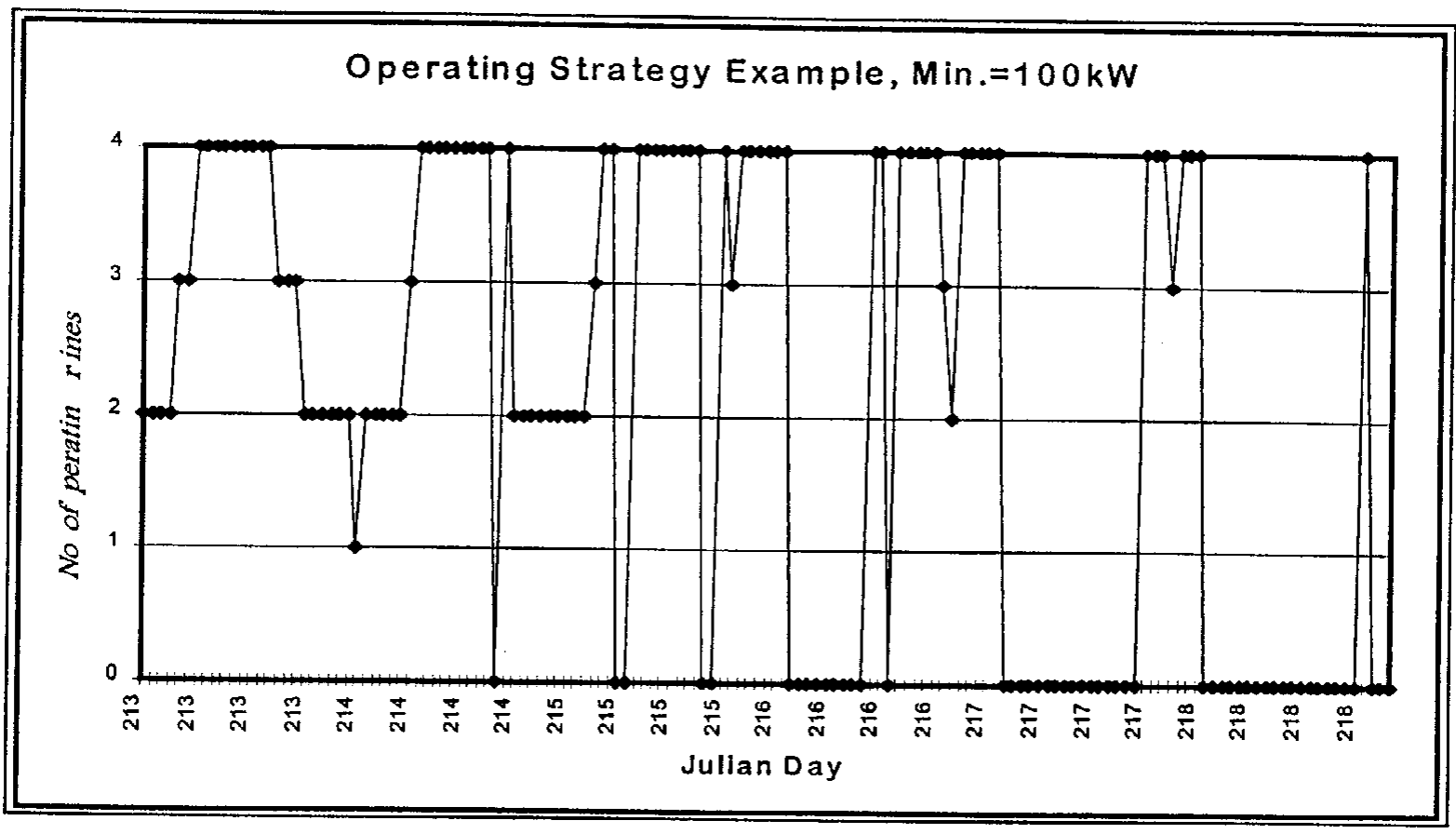

Figure 4. Similar to Figure 2 but with the minimum set-point for the diesel load at $100 \mathrm{~kW}$. Note that the period of time on late day 213 and early day 214 allows a second turbine to operate for 12 of 13 hours.

\section{The Economics of Wind Energy on SNI.}

The economics of a wind energy project can become quite complex due to financing arrangements. It is assumed for this exercise that the wind energy project is bought and paid for as a capitol development by the Navy. While that simplifies the calculation considerably, there are sufficient unknowns that some values are, at best, estimates. Here again, the estimates are reasonably conservative.

The cost, per turbine, installed on the island, is assumed to be $\$ 337,500.00$ in 1996 dollars. This value simply assumes the cost is $\$ 1500.00$ per $\mathrm{kW}$ installed. While this appears to be an above market price, the costs of installing this small number of turbines on off-shore islands is going to be fairly high since there would be a requirement for the contractor to provide and ship to the island all the necessary heavy equipment including a portable concrete batch plant. This number may be excessively high but, again, it is conservative. The cost of the entire installation of four turbines is about $\$ 1,350,000.00$ total. Electrical infrastructure and control systems are additional but are a relatively small portion of the total cost. The life expectancy for these turbines according to Navy criteria, is to be 20 years $^{1}$ and thus, the per year amortization amounts to $\sim \$ 67,500$ PA

\footnotetext{
${ }^{1}$ In the wind energy industry, the presumed and design life is typically 30 years however the Navy has made the assumption that the wind turbines will have a life expectancy of only 20 years.
} 


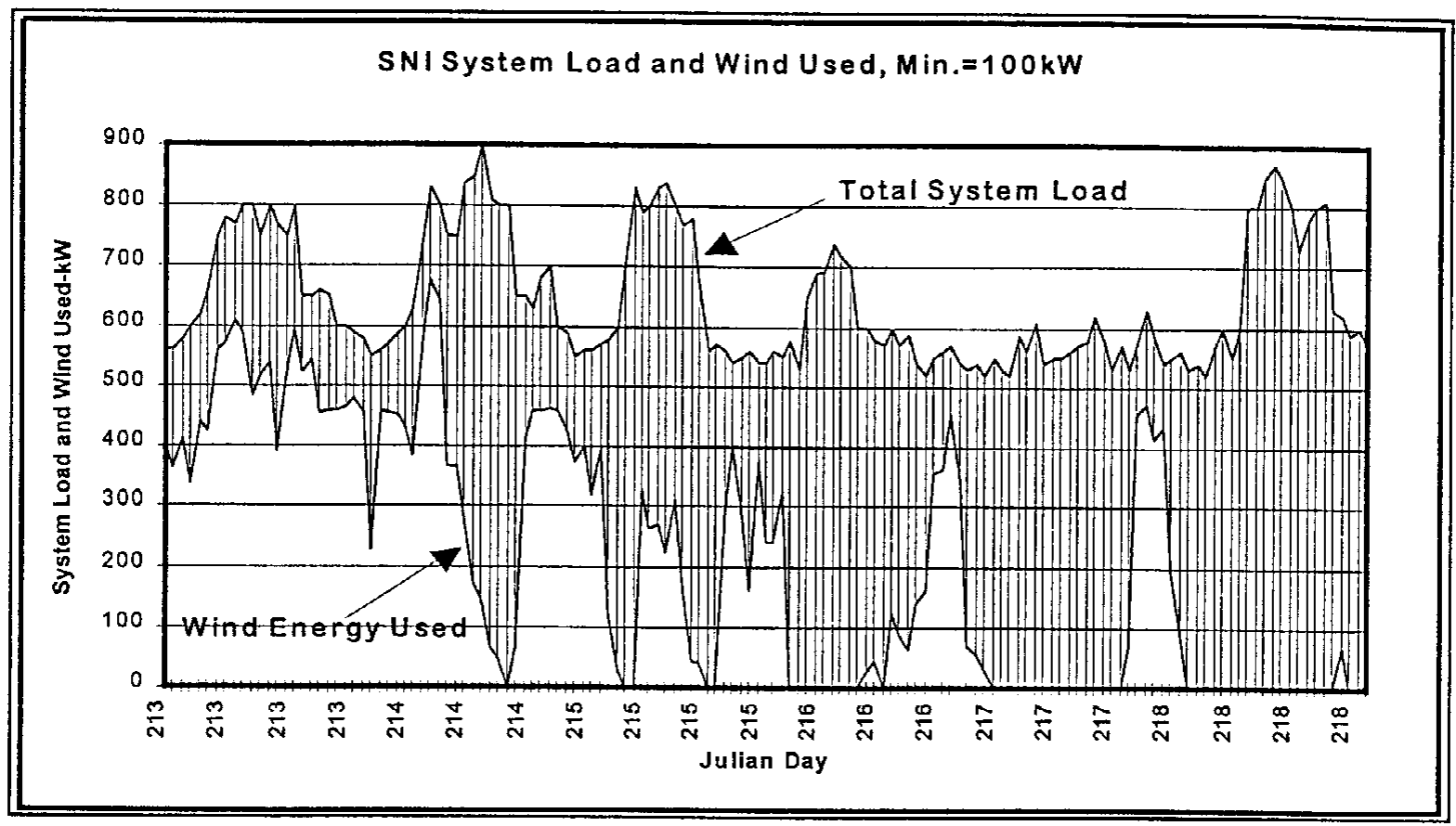

Figure 5. Similar to Figure 3 but with the minimum set-point for the diesel load at $100 \mathrm{~kW}$.

The diesel fuel cost, or in the case of San Nicolas, the cost of $J P-5^{2}$, their reported fuel of choice, was determined to be $\sim \$ 1.14$ gal. $^{-1}$ at the site. This value includes a $5 \xi$ charge for administrative handling. Numbers such as this can easily be changed in the model. An additional charge associated with the cost of fuel is the cost of cleaning the barge tanks with each shipment. That cost is $\$ 25,000$ per barge load. This charge is incurred $\sim 10$ times per year for a total cost of $\$ 250,000$.

The diesel power plant also has certain costs. While the original capital costs are ignored here, a "sinking fund" is established to provide for the replacement of the engines. The life of such engines is set at 10 years and the cost of replacement is estimated to be about $\$ 700.00 / \mathrm{kW}$ or $\$ 2,450,000$ for all five engines. Amortized over 10 years this is simply taken as $\$ 245,000 /$ year. Another charge that needs to be added to the O\&M costs for the diesel plant is a $\$ 250,000 /$ year contract for overhaul of all five engines after 2000 run-hours. This charge has apparently been nearly annual in the past but is pegged to the 2000 hour run time and is, therefore, less with the addition of wind energy. For the year 1989, the total number of engine hours was 9983 hours, essentially 10,000 hours. With the addition of wind, the number of hours the diesels operate is presumed to be reduced by the ratio of $\mathrm{kWh}$ without wind to that with wind. The overhaul contract costs on an annual basis would be reduced to $\$ 186,630$ if the minimum set point for the diesel plant was $200 \mathrm{~kW}$ and further reduced to $\$ 172,120$ if the minimum can be set to $100 \mathrm{~kW}$.

A very serious consideration concerning the diesel plant and one of the major differences between the HYBRID2 model and this simple spread sheet is fuel use. The HYBRID2 model incorporates a built-in function that calculates the diesel fuel utilization. This function is based on published observations and is a linear function of load with an offset at zero load (idle speed). This is a good example of an attribute of the model that is appropriate with subhourly data and a smaller system but is questionable with only hourly averaged data and a large system. In the spread sheet model, and in reality, the engines are never at idle or shut off unless there is another on line. Therefore a simple value for the $\mathrm{kWh} / \mathrm{gal}$ was assigned based on the best available information and experience with other similar sites and was not calculated via the function .

\footnotetext{
${ }^{2}$ The diesel engine manufacturers recommend that a "chiller" be added to JP-5 to increase it's lubricity and reduce wear on the fuel pump, the injection pump and the injectors.
} 


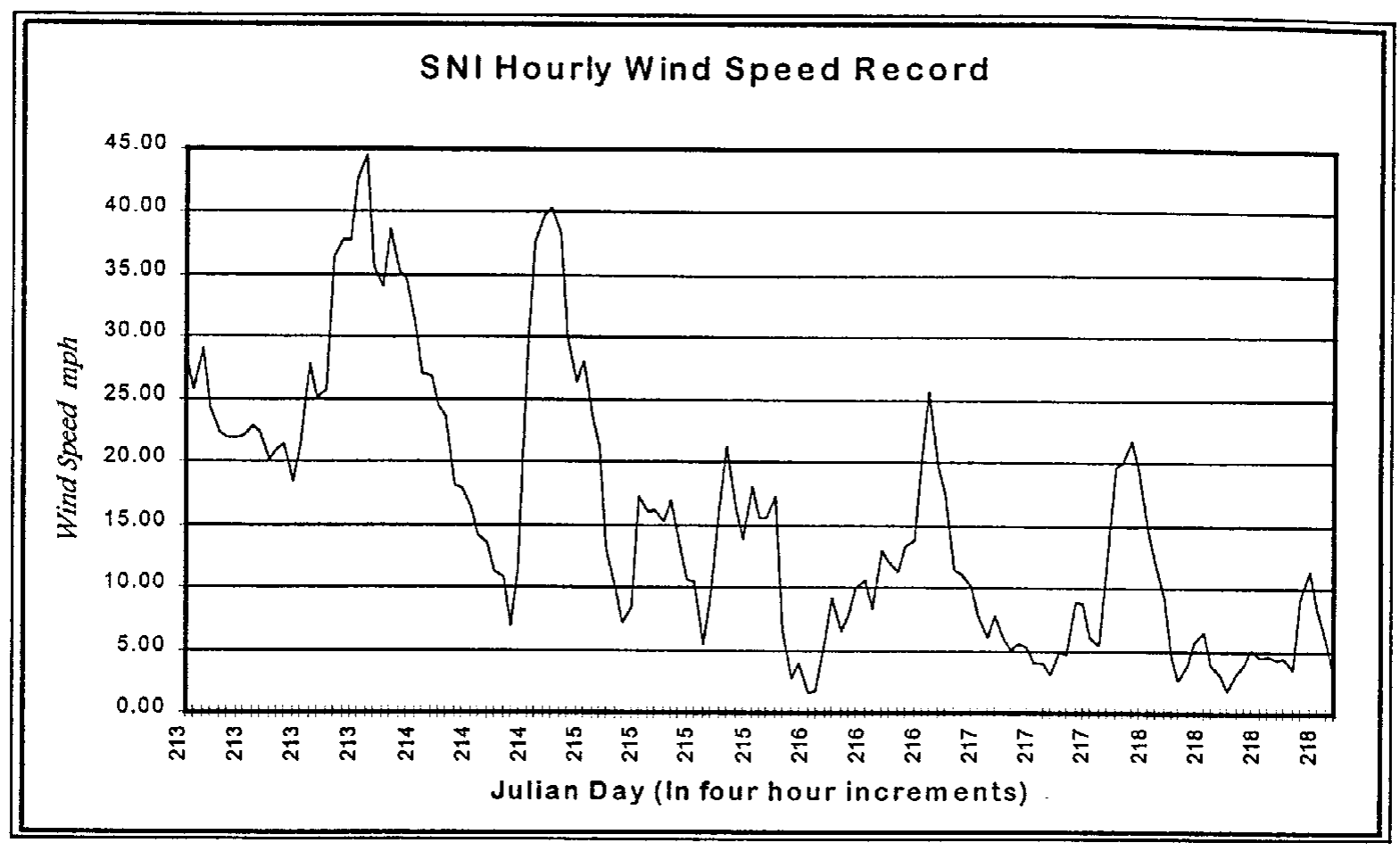

Figure 6. Time series plot of the wind speed during the same period of time as that shown in figures $2,3,4$, and 5 .

\section{The Results}

Included as an addendum to this report is a copy of the actual spread sheet on 3.5" diskettes. By simply convolving the wind speed to the power curve of the wind turbine for all 8760 hours of the year one gets the number of kWh you might expect assuming $100 \%$ availability of the wind turbine. In this exercise, there is no arbitrary assignment of WTG availability. It is the authors contention that it is meaningless to assign an availability since 1) there are sufficient lulls in the wind to perform most maintenance functions and 2) with a constrained, four WTG plant there is nearly always a "spare" turbine to replace one that might be down for some longer duration maintenance. A third and final point would be that today's wind turbines are exhibiting an availability of $>97-98 \%$. Therefore, availability deems to be a "non-issue" in this circumstance. If desired, some sort of Monte Carlo simulation of turbine outages based on experience could easily be added. Also, there were no deductions for losses due to "Array Effects" since there were only to be four wind turbines and the wind has a prevailing direction. Siting of a four turbine array under these circumstances should be straight forward enough to be able to avoid any such effects. There will be some electrical losses in the lines and transformers but these are small enough that the conservative approach to this entire analysis probably has them covered

The result of convoluting the wind speed data with the example wind turbine power curve is that a single turbine should produce about 675,000 kilowatt hours of energy per year at the San Nicolas Island site for the year modeled. That is equal to a capacity factor of $34.2 \%$ - a number that tends to indicate the resource at the site is extremely good. Again, assuming no artificial availability numbers, with all four turbines allowed to run unconstrained the production swells to 2.7 million kilowatt hours. In fact, however, assuming the constraints imposed by the operating strategy requiring a minimum $200 \mathrm{~kW}$ load for the diesel(s), the combined, usable energy production of the four wind turbines is only about 1.43 million $\mathrm{kWh}$ of energy for the year. The result of re-running the model using a $100 \mathrm{~kW}$ minimum load constraint showed that the number of usable $\mathrm{kWh}$ increases to 1.75 million. The reduction in cost is most easily seen as the fuel cost per $\mathrm{kWh}$ (saved) plus the $O \& M$ cost $/ \mathrm{kWh}$ minus the added cost of O\&M on the wind turbine. Table 3 , below summarizes the best estimates of the apparent cost savings.

Figure 7 shows the number of hours that each of four turbines would be running during the year with the $200 \mathrm{~kW}$ minimum diesel constraint. This is taken directly from the model data and indicates that out of one year ( 8760 hours) nearly 7400 hours had sufficient wind and system load to have at least one wind turbine running, monotonically decreasing to about 4500 hours with sufficient wind and system load for four turbines to be operating. 
Table 3. Summary of costs and savings assuming the $200 \mathrm{~kW}$ minimum set point.

\begin{tabular}{|c|c|c|}
\hline Item & Without Wind Turbines & With Wind Turbines \\
\hline Wind Turbine O\&M/Yr.@0.01/kWh & $\$ 0.00$ & $\$ 14,305.45$ \\
\hline Diesel O\&M/Yr.@0.066/kWh & $\$ 375,863.76$ & $\$ 278061.61$ \\
\hline Diesel Fuel Costs@ @ \$1.14/gal & $\$ 494,900.31$ & $\$ 369,452.49$ \\
\hline Annual Amortization of Wind Turbines & $\$ 0.00$ & $\$ 67,500.00$ \\
\hline Sinking Fund to Replace Diesels & $\$ 210,000.00$ & $\$ 210,999.00$ \\
\hline 2000 hour Engine Overhauls & $\$ 250,000.00$ & $* * \$ 186,629.75$ \\
\hline Totals & $\$ \$ 1,330,764.07$ & $\$ 1,125,949.30$ \\
\hline Savings & & $\$ 204,814.76$ \\
\hline
\end{tabular}

** With the set point at $100 \mathrm{~kW}$, this number becomes $\$ 172,118.74$ and the total savings become $\$ 266,396.14$.

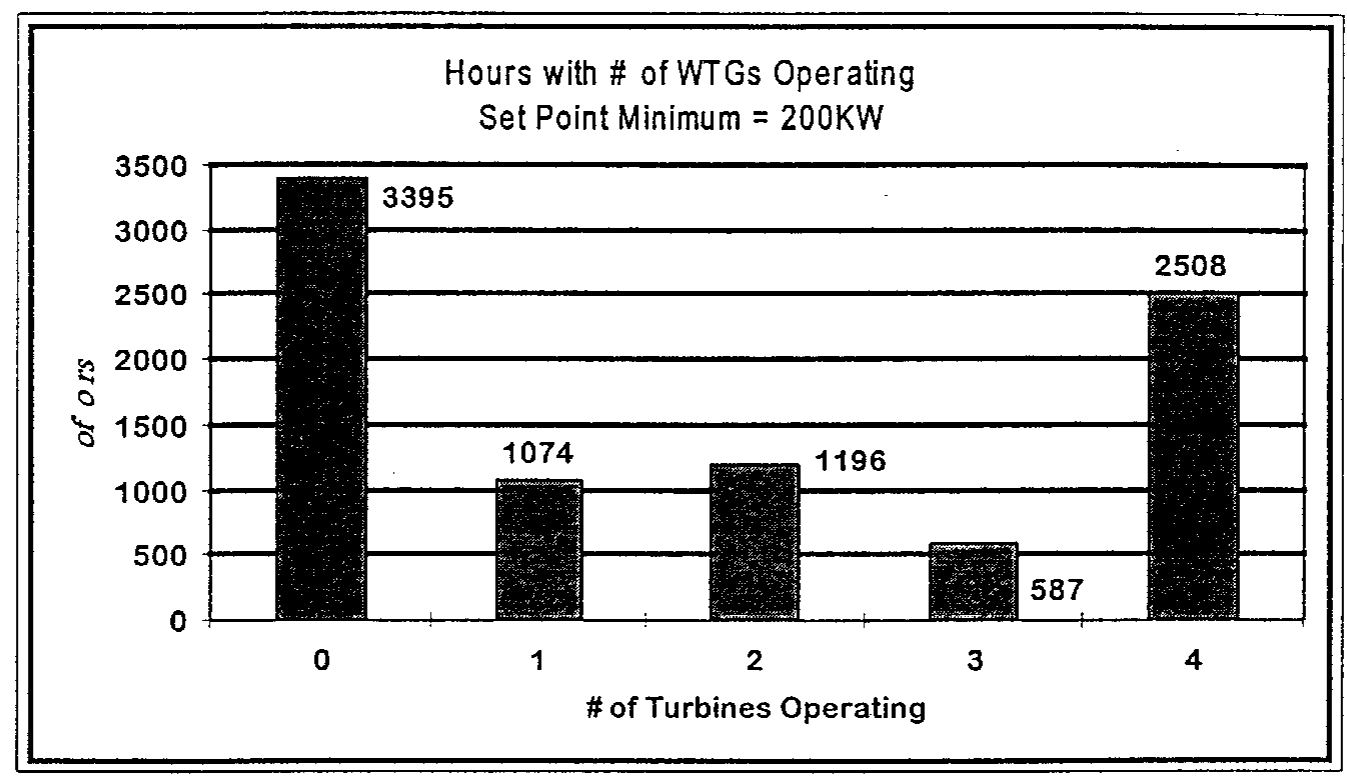

Figure 7. A Histogram of the number of hours that each of the four available WTG would operate with the operating strategy modeled herein.

The difference in the estimates is between $\$ 205,000$ to $\$ 266,000$ per year saved by adding the four wind turbines. This equates to amortizing one wind turbine every 1.6 or 1.4 years depending on the minimum set point. This seems to provide a good rate of return of investment .

For completeness sake Figure 8 , shown below, is similar to figure 7 but with the minimum diesel constraint set to $100 \mathrm{Kw}$. 


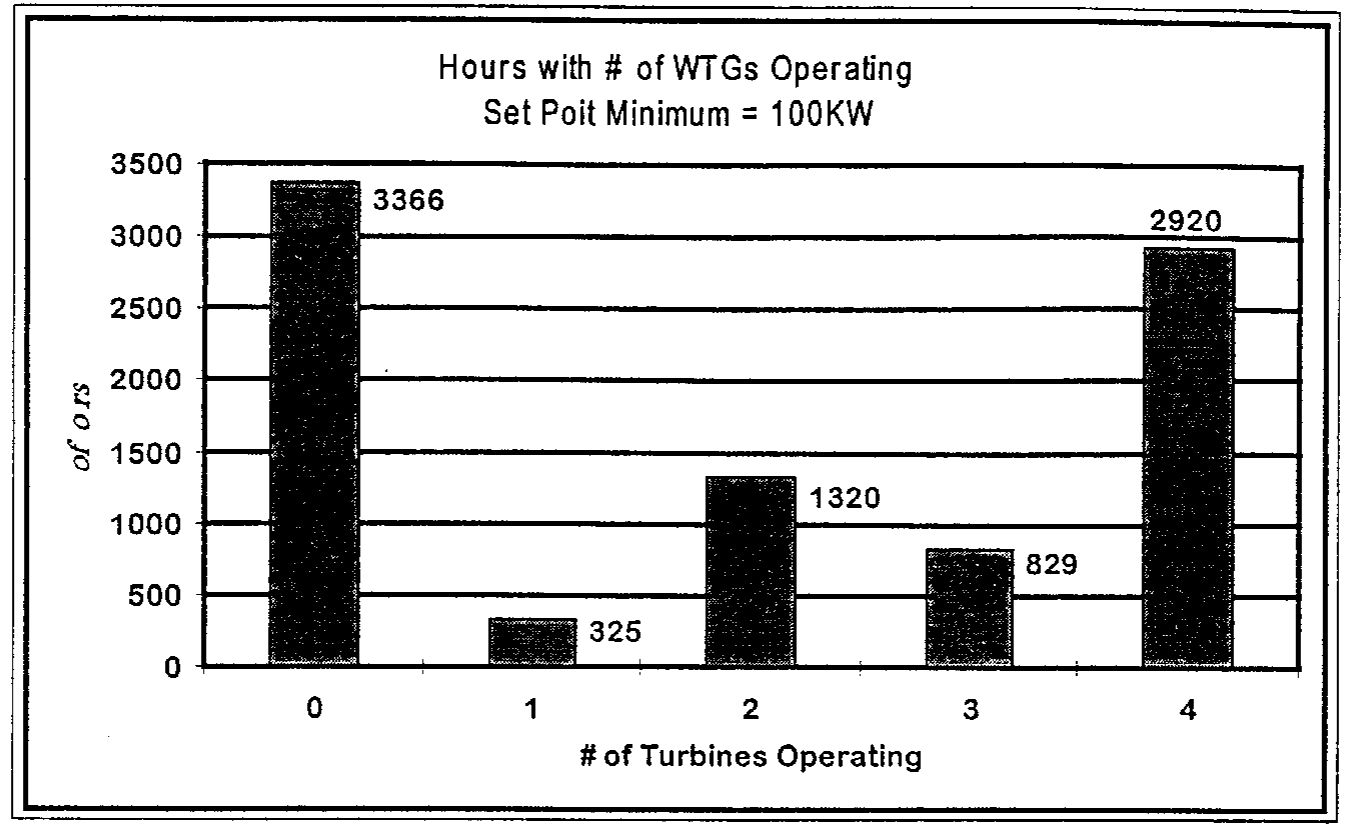

Figure 8. A Histogram of the number of hours that each of the four available WTG would operate with the operating strategy minimum set to 100

\section{Conclusions}

Although it is too early to make very bold statements, it appears that this simple wind/diesel model performs quite adequately for the purpose that it is intended. Students getting into the higher mathematics of college frequently do not comprehend the difference between resolution and accuracy. The simple spreadsheet model described herein has all the resolution the data can justify. The accuracy is a question but is certainly within the $10 \%$ region. A model such as HYBRID2, afforded the luxury of high temporal resolution data and more quantitative data on such things as fuel utilization, may provide a clearer look into the minute by minute operational details but the accuracy relative to reality is also a question. With the low rate data available for this investigation, the HYBRID2 model is clearly an over-kill and probably can not produce any better (more accurate) results.

The Navy has expressed concern over the potential of a wind power plant experiencing large scale changes in output very rapidly thus causing the diesels to work harder to follow load. While this task does not include the documentation of such, it is well documented that the stronger the average winds, the lower the variance and conversely, the lower the average winds, the higher the variance, percentage-wise. Further, there has been expressed the concern that the jitter or variance in the wind will add to the variance in the load. While this has never been documented to the best of the authors knowledge, the one thing that has been documented is that when multiple WTGs are on line, their long term mean power is strictly additive while the variances add as the reciprocal of the number of turbines. It is logical that when considering a "noisy source" (the WTGs) interacting with a "noisy sink" (the load), their variances must at least partially cancel. It would be a worthwhile exercise to take a short period (i.e. a week) of high resolution ( $\left.1 \mathrm{sec}^{-1}\right)$ wind speed and direction data and synonymous load data at the island to investigate the apparent effects of adding wind to the San Nicolas Island power system and might be considered a mandatory first step. 


\section{APPENDIX D: \\ Wind-Diesel System Operational Guidelines}

This appendix contains the wind-diesel system operational guidelines that lead to the overall operational scenario. This scenario was developed by NREL and its sub-contractors for the SERDP-funded San Clemente Island wind turbine installation.

This appendix conveys information on the amount of wind turbine electrical energy that can be utilized with the SCI diesel system and on the appropriate use of external loads to manage excess wind energy. Fuel savings are still achievable with low demand when the wind-diesel system includes a $225 \mathrm{~kW}$ load bank. 


\begin{tabular}{|c|c|c|c|c|c|c|c|c|c|c|c|c|}
\hline \multirow{3}{*}{$\begin{array}{l}\text { DEMAND } \\
\text { LOAD (kW) }\end{array}$} & \multicolumn{12}{|c|}{ WIND SPEED (mph) } \\
\hline & \multicolumn{4}{|c|}{$\begin{array}{r}10 \\
\end{array}$} & \multicolumn{4}{|c|}{15} & \multicolumn{4}{|c|}{20} \\
\hline & \#WG & WG (kW) & DG (kW) & LB $(\mathrm{kW})$ & \#WG & WG (kW) & DG (kW) & LB (kW) & \#WG & WG (kW) & DG (kW) & LB (kW) \\
\hline \multirow[t]{4}{*}{400} & 1 & 19.5 & 380.5 & 0.0 & 1 & 57.1 & 342.9 & 0.0 & 1 & 118.7 & \begin{tabular}{|l|}
781.3 \\
\end{tabular} & 0.0 \\
\hline & 2 & 39.0 & 361.0 & 0.0 & 2 & 114.2 & 285.8 & 0.0 & 2 & 237.4 & 162.6 & 0.0 \\
\hline & 3 & 58.5 & 341.5 & 0.0 & 3 & 171.3 & 228.7 & 0.0 & 3 & 356.1 & 118.9 & 75.0 \\
\hline & 4 & 78.0 & 322.0 & 0.0 & 4 & 228.4 & 171.6 & 0.0 & 4 & 474.8 & 150.2 & 225.0 \\
\hline \multirow[t]{4}{*}{500} & 1 & 19.5 & 480.5 & 0.0 & 1 & 57.1 & 442.9 & 0.0 & 1 & 118.7 & 381.3 & 0.0 \\
\hline & 2 & 39.0 & 461.0 & 0.0 & 2 & 114.2 & 385.8 & 0.0 & 2 & 237.4 & 262.6 & 0.0 \\
\hline & 3 & 58.5 & 441.5 & 0.0 & 3 & 171.3 & 328.7 & 0.0 & 3 & 356.1 & 143.9 & 0.0 \\
\hline & 4 & 78.0 & 422.0 & 0.0 & 4 & 228.4 & 271.6 & 0.0 & 4 & 474.8 & 100.2 & 75.0 \\
\hline \multirow[t]{4}{*}{600} & 1 & 19.5 & 580.5 & 0.0 & 1 & 57.1 & 542.9 & 0.0 & 1 & 118.7 & 481.3 & 0.0 \\
\hline & 2 & 39.0 & 561.0 & 0.0 & 2 & 114.2 & 485.8 & 0.0 & 2 & 237.4 & 362.6 & 0.0 \\
\hline & 3 & 58.5 & 541.5 & 0.0 & 3 & 171.3 & 428.7 & 0.0 & 3 & 356.1 & 243.9 & 0.0 \\
\hline & 4 & 78.0 & 522.0 & 0.0 & 4 & 228.4 & 371.6 & 0.0 & 4 & 474.8 & 125.2 & 0.0 \\
\hline \multirow[t]{4}{*}{700} & 1 & 19.5 & 680.5 & 0.0 & 1 & 57.1 & 642.9 & 0.0 & 1 & 118.7 & 581.3 & 0.0 \\
\hline & 2 & 39.0 & 661.0 & 0.0 & 2 & 114.2 & 585.8 & 0.0 & 2 & 237.4 & 462.6 & 0.0 \\
\hline & 3 & 58.5 & 641.5 & 0.0 & 3 & 171.3 & 528.7 & 0.0 & 3 & 356.1 & 343.9 & 0.0 \\
\hline & 4 & 78.0 & 622.0 & 0.0 & 4 & 228.4 & 471.6 & 0.0 & 4 & 474.8 & 225.2 & 0.0 \\
\hline \multirow[t]{4}{*}{800} & 1 & 19.5 & 780.5 & 0.0 & 1 & 57.1 & 742.9 & 0.0 & 1 & 118.7 & 681.3 & 0.0 \\
\hline & 2 & 39.0 & 761.0 & 0.0 & 2 & 114.2 & 685.8 & 0.0 & 2 & 237.4 & 562.6 & 0.0 \\
\hline & 3 & 58.5 & 741.5 & 0.0 & 3 & 171.3 & 628.7 & 0.0 & 3 & 356.1 & 443.9 & 0.0 \\
\hline & 4 & 78.0 & 722.0 & 0.0 & 4 & 228.4 & 571.6 & 0.0 & 4 & 474.8 & 325.2 & 0.0 \\
\hline \multirow[t]{4}{*}{900} & 1 & 19.5 & 880.5 & 0.0 & 1 & 57.1 & 842.9 & 0.0 & 1 & 118.7 & 781.3 & 0.0 \\
\hline & 2 & 39.0 & 861.0 & 0.0 & 2 & 114.2 & 785.8 & 0.0 & 2 & 237.4 & 662.6 & 0.0 \\
\hline & 3 & 58.5 & 841.5 & 0.0 & 3 & 171.3 & 728.7 & 0.0 & 3 & 356.1 & 543.9 & 0.0 \\
\hline & 4 & 78.0 & 822.0 & 0.0 & 4 & 228.4 & 671.6 & 0.0 & 4 & 474.8 & 425.2 & 0.0 \\
\hline \multirow[t]{4}{*}{1000} & 1 & 19.5 & 980.5 & 0.0 & 1 & 57.1 & 942.9 & 0.0 & 1 & 118.7 & 881.3 & 0.0 \\
\hline & 2 & 39.0 & 961.0 & 0.0 & 2 & 114.2 & 885.8 & 0.0 & 2 & 237.4 & 762.6 & 0.0 \\
\hline & 3 & 58.5 & 941.5 & 0.0 & 3 & 171.3 & 828.7 & 0.0 & 3 & 356.1 & 643.9 & 0.0 \\
\hline & 4 & 78.0 & 922.0 & 0.0 & 4 & 228.4 & 771.6 & 0.0 & 4 & 474.8 & 525.2 & 0.0 \\
\hline \multirow[t]{4}{*}{1100} & 1 & 19.5 & $1,080.5$ & 0.0 & 1 & 57.1 & $1,042.9$ & 0.0 & 1 & 118.7 & 981.3 & 0.0 \\
\hline & 2 & 39.0 & $1,061.0$ & 0.0 & 2 & 114.2 & 985.8 & 0.0 & 2 & 237.4 & 862.6 & 0.0 \\
\hline & 3 & 58.5 & $1,041.5$ & 0.0 & 3 & 171.3 & 928.7 & 0.0 & 3 & 356.1 & 743.9 & 0.0 \\
\hline & 4 & 78.0 & $1,022.0$ & 0.0 & 4 & 228.4 & 871.6 & 0.0 & 4 & 474.8 & 625.2 & 0.0 \\
\hline \multirow[t]{4}{*}{1200} & 1 & 19.5 & $1,180.5$ & 0.0 & 1 & 57.1 & $1,142.9$ & 0.0 & 1 & 118.7 & $1,081.3$ & 0.0 \\
\hline & 2 & 39.0 & $1,161.0$ & 0.0 & 2 & 114.2 & $1,085.8$ & 0.0 & 2 & 237.4 & 962.6 & 0.0 \\
\hline & 3 & 58.5 & $1,141.5$ & 0.0 & 3 & 171.3 & $1,028.7$ & 0.0 & 3 & 356.1 & 843.9 & 0.0 \\
\hline & 4 & 78.0 & $1,122.0$ & 0.0 & 4 & 228.4 & 971.6 & 0.0 & 4 & 474.8 & 725.2 & 0.0 \\
\hline \multirow[t]{4}{*}{1300} & 1 & 19.5 & $1,280.5$ & 0.0 & 1 & 57.1 & $1,242.9$ & 0.0 & 1 & 118.7 & $1,181.3$ & 0.0 \\
\hline & 2 & 39.0 & $1,261.0$ & 0.0 & 2 & 114.2 & $1,185.8$ & 0.0 & 2 & 237.4 & $1,062.6$ & 0.0 \\
\hline & 3 & 58.5 & $1,241.5$ & 0.0 & 3 & 171.3 & $1,128.7$ & 0.0 & 3 & 356.1 & 943.9 & 0.0 \\
\hline & 4 & 78.0 & $1,222.0$ & 0.0 & 4 & 228.4 & $1,071.6$ & 0.0 & 4 & 474.8 & 825.2 & 0.0 \\
\hline \multirow[t]{4}{*}{1400} & 1 & 19.5 & $1,380.5$ & 0.0 & 1 & 57.1 & $1,342.9$ & 0.0 & 1 & 118.7 & $1,281.3$ & 0.0 \\
\hline & 2 & 39.0 & $1,361.0$ & 0.0 & 2 & 114.2 & $1,285.8$ & 0.0 & 2 & 237.4 & $1,162.6$ & 0.0 \\
\hline & 3 & 58.5 & $1,341.5$ & 0.0 & 3 & 171.3 & $1,228.7$ & 0.0 & 3 & 356.1 & $1,043.9$ & 0.0 \\
\hline & 4 & 78.0 & $1,322.0$ & 0.0 & 4 & 228.4 & $1,171.6$ & 0.0 & 4 & 474.8 & 925.2 & 0.0 \\
\hline \multirow[t]{4}{*}{1500} & 1 & 19.5 & $1,480.5$ & 0.0 & 1 & 57.1 & $1,442.9$ & 0.0 & 1 & 118.7 & $1,381.3$ & 0.0 \\
\hline & 2 & 39.0 & $1,461.0$ & 0.0 & 2 & 114.2 & $1,385.8$ & 0.0 & 2 & 237.4 & $1,262.6$ & 0.0 \\
\hline & 3 & 58.5 & $1,441.5$ & 0.0 & 3 & 171.3 & $1,328.7$ & 0.0 & 3 & 356.1 & $1,143.9$ & 0.0 \\
\hline & 4 & 78.0 & $1,422.0$ & 0.0 & 4 & 228.4 & $1,271.6$ & 0.0 & 4 & 474.8 & $1,025.2$ & 0.0 \\
\hline
\end{tabular}

\begin{tabular}{|l|} 
KEY \\
\#WG : NUMBER OF WIND GENERATORS \\
WG : WIND GENERATOR LOAD PRODUCTION $(\mathrm{kW})$ \\
DG : DIESEL GENERATOR LOAD PRODUCTION $(\mathrm{kW})$ \\
LB : LOAD BANK LOAD DISSIPATION $(\mathrm{kW})$
\end{tabular}




\begin{tabular}{|c|c|c|c|c|c|c|c|c|c|c|c|c|}
\hline \multirow{3}{*}{$\begin{array}{l}\text { DEMAND } \\
\text { LOAD (kW) }\end{array}$} & \multicolumn{12}{|c|}{ WIND SPEED (mph) } \\
\hline & \multicolumn{4}{|c|}{25} & \multicolumn{4}{|c|}{30} & \multicolumn{4}{|c|}{35} \\
\hline & \#WG & WG (kW) & DG (kW) & LB (kW) & \#WG & WG (kW) & DG (kW) & LB (kW) & \#WG & WG (kW) & DG (kW) & LB (kW) \\
\hline \multirow[t]{4}{*}{400} & $\begin{array}{ll}1 \\
\end{array}$ & $\begin{array}{r}171.4 \\
\end{array}$ & 228.6 & 0.0 & 1 & 206.0 & 194.0 & 0.0 & 1 & 227.0 & 173.0 & 0.0 \\
\hline & 2 & 342.8 & 132.2 & 75.0 & 2 & 412.0 & 138.0 & 150.0 & 2 & 454.0 & 171.0 & 225.0 \\
\hline & 3 & 514.2 & 110.8 & 225.0 & 3 & OFF & & & 3 & OFF & & \\
\hline & 4 & OFF & & & 4 & OFF & & & 4 & OFF & & \\
\hline \multirow[t]{4}{*}{500} & 1 & 171.4 & 328.6 & 0.0 & 1 & 206.0 & 294.0 & 0.0 & 1 & 227.0 & 273.0 & 0.0 \\
\hline & 2 & 342.8 & 157.2 & 0.0 & 2 & 412.0 & 163.0 & 75.0 & 2 & 454.0 & 121.0 & 75.0 \\
\hline & 3 & 514.2 & 135.8 & 150.0 & 3 & 618.0 & 107.0 & 225.0 & 3 & OFF & & \\
\hline & 4 & OFF & & & 4 & OFF & & & 4 & OFF & & \\
\hline \multirow[t]{4}{*}{600} & 1 & 171.4 & 428.6 & 0.0 & 1 & 206.0 & 394.0 & 0.0 & 1 & 227.0 & 373.0 & 0.0 \\
\hline & 2 & 342.8 & 257.2 & 0.0 & 2 & 412.0 & 188.0 & 0.0 & 2 & 454.0 & 146.0 & 0.0 \\
\hline & 3 & 514.2 & 160.8 & 75.0 & 3 & 618.0 & 132.0 & 150.0 & 3 & 681.0 & 144.0 & 225.0 \\
\hline & 4 & 685.6 & 139.4 & 225.0 & 4 & OFF & & & 4 & OFF & & \\
\hline \multirow[t]{4}{*}{700} & 1 & 171.4 & 528.6 & 0.0 & 1 & 206.0 & 494.0 & 0.0 & 1 & 227.0 & 473.0 & 0.0 \\
\hline & 2 & 342.8 & 357.2 & 0.0 & 2 & 412.0 & 288.0 & 0.0 & 2 & 454.0 & 246.0 & 0.0 \\
\hline & 3 & 514.2 & 185.8 & 0.0 & 3 & 618.0 & 157.0 & 75.0 & 3 & 681.0 & 169.0 & 150.0 \\
\hline & 4 & 685.6 & 164.4 & 150.0 & 4 & 824.0 & 101.0 & 225.0 & 4 & OFF & & \\
\hline \multirow[t]{4}{*}{800} & 1 & 171.4 & 628.6 & 0.0 & 1 & 206.0 & 594.0 & 0.0 & 1 & 227.0 & 573.0 & 0.0 \\
\hline & 2 & 342.8 & 457.2 & 0.0 & 2 & 412.0 & 388.0 & 0.0 & 2 & 454.0 & 346.0 & 0.0 \\
\hline & 3 & 514.2 & 285.8 & 0.0 & 3 & 618.0 & 182.0 & 0.0 & 3 & 681.0 & 119.0 & 0.0 \\
\hline & 4 & 685.6 & 114.4 & 0.0 & 4 & 824.0 & 126.0 & 150.0 & 4 & 908.0 & 117.0 & 225.0 \\
\hline \multirow[t]{4}{*}{900} & 1 & 171.4 & 728.6 & 0.0 & 1 & 206.0 & 694.0 & 0.0 & 1 & 227.0 & 673.0 & 0.0 \\
\hline & 2 & 342.8 & 557.2 & 0.0 & 2 & 412.0 & 488.0 & 0.0 & 2 & 454.0 & 446.0 & 0.0 \\
\hline & 3 & 514.2 & 385.8 & 0.0 & 3 & 618.0 & 282.0 & 0.0 & 3 & 681.0 & 219.0 & 0.0 \\
\hline & 4 & 685.6 & 214.4 & 0.0 & 4 & 824.0 & 151.0 & 75.0 & 4 & 908.0 & 142.0 & 150.0 \\
\hline \multirow[t]{4}{*}{1000} & 1 & 171.4 & 828.6 & 0.0 & 1 & 206.0 & 794.0 & 0.0 & 1 & 227.0 & 773.0 & 0.0 \\
\hline & 2 & 342.8 & 657.2 & 0.0 & 2 & 412.0 & 588.0 & 0.0 & 2 & 454.0 & 546.0 & 0.0 \\
\hline & 3 & 514.2 & 485.8 & 0.0 & 3 & 618.0 & 382.0 & 0.0 & 3 & 681.0 & 319.0 & 0.0 \\
\hline & 4 & 685.6 & 314.4 & 0.0 & 4 & 824.0 & 176.0 & 0.0 & 4 & 908.0 & 167.0 & 75.0 \\
\hline \multirow[t]{4}{*}{1100} & 1 & 171.4 & 928.6 & 0.0 & 1 & 206.0 & 894.0 & 0.0 & 1 & 227.0 & 873.0 & 0.0 \\
\hline & 2 & 342.8 & 757.2 & 0.0 & 2 & 412.0 & 688.0 & 0.0 & 2 & 454.0 & 646.0 & 0.0 \\
\hline & 3 & 514.2 & 585.8 & 0.0 & 3 & 618.0 & 482.0 & 0.0 & 3 & 681.0 & 419.0 & 0.0 \\
\hline & 4 & 685.6 & 414.4 & 0.0 & 4 & 824.0 & 276.0 & 0.0 & 4 & 908.0 & 192.0 & 0.0 \\
\hline \multirow[t]{4}{*}{1200} & 1 & 171.4 & $1,028.6$ & 0.0 & 1 & 206.0 & 994.0 & 0.0 & 1 & 227.0 & 973.0 & 0.0 \\
\hline & 2 & 342.8 & 857.2 & 0.0 & 2 & 412.0 & 788.0 & 0.0 & 2 & 454.0 & 746.0 & 0.0 \\
\hline & 3 & 514.2 & 685.8 & 0.0 & 3 & 618.0 & 582.0 & 0.0 & 3 & 681.0 & 519.0 & 0.0 \\
\hline & 4 & 685.6 & 514.4 & 0.0 & 4 & 824.0 & 376.0 & 0.0 & 4 & 908.0 & 292.0 & 0.0 \\
\hline \multirow[t]{4}{*}{1300} & 1 & 171.4 & $1,128.6$ & 0.0 & 1 & 206.0 & $1,094.0$ & 0.0 & 1 & 227.0 & $1,073.0$ & 0.0 \\
\hline & 2 & 342.8 & 957.2 & 0.0 & 2 & 412.0 & 888.0 & 0.0 & 2 & 454.0 & 846.0 & 0.0 \\
\hline & 3 & 514.2 & \begin{tabular}{|l|}
785.8 \\
\end{tabular} & 0.0 & 3 & 618.0 & 682.0 & 0.0 & 3 & 681.0 & 619.0 & 0.0 \\
\hline & 4 & 685.6 & $\begin{array}{ll}614.4 \\
\end{array}$ & 0.0 & 4 & 824.0 & 476.0 & 0.0 & 4 & 908.0 & 392.0 & 0.0 \\
\hline \multirow[t]{4}{*}{1400} & 1 & 171.4 & $1,228.6$ & 0.0 & 1 & 206.0 & $1,194.0$ & 0.0 & 1 & 227.0 & $1,173.0$ & 0.0 \\
\hline & 2 & 342.8 & $1,057.2$ & 0.0 & 2 & 412.0 & 988.0 & 0.0 & 2 & 454.0 & 946.0 & 0.0 \\
\hline & 3 & 514.2 & 885.8 & 0.0 & 3 & 618.0 & 782.0 & 0.0 & 3 & 681.0 & 719.0 & 0.0 \\
\hline & 4 & 685.6 & 714.4 & 0.0 & 4 & 824.0 & 576.0 & 0.0 & 4 & 908.0 & 492.0 & 0.0 \\
\hline \multirow[t]{4}{*}{1500} & 1 & 171.4 & $1,328.6$ & 0.0 & 1 & 206.0 & $1,294.0$ & 0.0 & 1 & 227.0 & $1,273.0$ & 0.0 \\
\hline & 2 & 342.8 & $1,157.2$ & 0.0 & 2 & 412.0 & $1,088.0$ & 0.0 & 2 & 454.0 & $1,046.0$ & 0.0 \\
\hline & 3 & 514.2 & 985.8 & 0.0 & 3 & 618.0 & 882.0 & 0.0 & 3 & 681.0 & 819.0 & 0.0 \\
\hline & 4 & 685.6 & 814.4 & 0.0 & 4 & 824.0 & 676.0 & 0.0 & 4 & 908.0 & 592.0 & 0.0 \\
\hline
\end{tabular}

\begin{tabular}{l} 
KEY \\
\#WG : NUMBER OF WIND GENERATORS \\
WG $:$ WIND GENERATOR LOAD PRODUCTION $(\mathrm{kW})$ \\
DG $:$ DIESEL GENERATOR LOAD PRODUCTION $(\mathrm{kW})$ \\
LB $:$ LOAD BANK LOAD DISSIPATION $(\mathrm{kW})$ \\
\hline
\end{tabular}




\begin{tabular}{|c|c|c|c|c|}
\hline \multirow{3}{*}{$\begin{array}{l}\text { DEMAND } \\
\text { LOAD (kW) }\end{array}$} & \multicolumn{4}{|c|}{ WIND SPEED (mph) } \\
\hline & \multicolumn{4}{|c|}{40} \\
\hline & \#WG & WG (kW) & DG (kW) & LB $(\mathrm{kW})$ \\
\hline \multirow[t]{4}{*}{400} & 1 & 230.0 & 170.0 & 0.0 \\
\hline & 2 & 460.0 & 165.0 & 225.0 \\
\hline & 3 & OFF & & \\
\hline & 4 & OFF & & \\
\hline \multirow[t]{4}{*}{500} & 1 & 230.0 & 270.0 & 0.0 \\
\hline & 2 & 460.0 & 115.0 & 75.0 \\
\hline & 3 & OFF & & \\
\hline & 4 & OFF & & \\
\hline \multirow[t]{4}{*}{600} & 1 & 230.0 & 370.0 & 0.0 \\
\hline & 2 & 460.0 & 140.0 & 0.0 \\
\hline & 3 & 690.0 & 135.0 & 225.0 \\
\hline & 4 & OFF & & \\
\hline \multirow[t]{4}{*}{700} & 1 & 230.0 & 470.0 & 0.0 \\
\hline & 2 & 460.0 & 240.0 & 0.0 \\
\hline & 3 & 690.0 & 160.0 & 150.0 \\
\hline & 4 & OFF & & \\
\hline \multirow[t]{4}{*}{800} & 1 & 230.0 & 570.0 & 0.0 \\
\hline & 2 & 460.0 & 340.0 & 0.0 \\
\hline & 3 & 690.0 & 110.0 & 0.0 \\
\hline & 4 & 920.0 & 105.0 & 225.0 \\
\hline \multirow[t]{4}{*}{900} & 1 & 230.0 & 670.0 & 0.0 \\
\hline & 2 & 460.0 & 440.0 & 0.0 \\
\hline & 3 & 690.0 & 210.0 & 0.0 \\
\hline & 4 & 920.0 & 130.0 & 150.0 \\
\hline \multirow[t]{4}{*}{1000} & 1 & 230.0 & 770.0 & 0.0 \\
\hline & 2 & 460.0 & 540.0 & 0.0 \\
\hline & 3 & 690.0 & 310.0 & 0.0 \\
\hline & 4 & 920.0 & 155.0 & 75.0 \\
\hline \multirow[t]{4}{*}{1100} & 1 & 230.0 & 870.0 & 0.0 \\
\hline & 2 & 460.0 & 640.0 & 0.0 \\
\hline & 3 & 690.0 & 410.0 & 0.0 \\
\hline & 4 & 920.0 & 180.0 & 0.0 \\
\hline \multirow[t]{4}{*}{1200} & 1 & 230.0 & 970.0 & 0.0 \\
\hline & 2 & 460.0 & 740.0 & 0.0 \\
\hline & 3 & 690.0 & 510.0 & 0.0 \\
\hline & 4 & 920.0 & 280.0 & 0.0 \\
\hline \multirow[t]{4}{*}{1300} & 1 & 230.0 & $1,070.0$ & 0.0 \\
\hline & 2 & 460.0 & 840.0 & 0.0 \\
\hline & 3 & 690.0 & 610.0 & 0.0 \\
\hline & 4 & 920.0 & 380.0 & 0.0 \\
\hline \multirow[t]{4}{*}{1400} & 1 & 230.0 & $1,170.0$ & 0.0 \\
\hline & 2 & 460.0 & 940.0 & 0.0 \\
\hline & 3 & 690.0 & 710.0 & 0.0 \\
\hline & 4 & 920.0 & 480.0 & 0.0 \\
\hline \multirow[t]{4}{*}{1500} & 1 & 230.0 & $1,270.0$ & 0.0 \\
\hline & 2 & 460.0 & $1,040.0$ & 0.0 \\
\hline & 3 & 690.0 & 810.0 & 0.0 \\
\hline & 4 & 920.0 & 580.0 & 0.0 \\
\hline
\end{tabular}

\begin{tabular}{|l|} 
KEY \\
\#WG : NUMBER OF WIND GENERATORS \\
WG : WIND GENERATOR LOAD PRODUCTION $(\mathrm{kW})$ \\
DG : DIESEL GENERATOR LOAD PRODUCTION $(\mathrm{kW})$ \\
LB : LOAD BANK LOAD DISSIPATION $(\mathrm{kW})$
\end{tabular}


INPUT

\begin{tabular}{|r|r|r|r|}
\hline $\begin{array}{r}\text { WIND SPEED } \\
(\mathrm{mph})\end{array}$ & $\begin{array}{r}\text { GEN LOAD } \\
(\mathrm{kW})\end{array}$ & $\begin{array}{r}\text { DG LOAD MIN } \\
(\mathrm{kW})\end{array}$ & $\begin{array}{r}\text { DG INC } \\
(\mathrm{kW})\end{array}$ \\
\hline 10 & 19.5 & 100.0 & 75.0 \\
\hline 15 & 57.1 & & \\
\hline 20 & 118.7 & & \\
\hline 25 & 171.4 \\
\hline 30 & 206.0 \\
\hline 35 & 227.0 \\
\hline 40 & 230.0 & & \\
\cline { 1 - 2 } & & & \\
& & &
\end{tabular}

105.0 
FUEL CONSUMPTION ESTIMATE

\begin{tabular}{|r|r|r|r|r|r|r|}
\cline { 2 - 7 } \multicolumn{1}{c|}{ WIND SPEED (10 $\mathbf{~ m p h}$ ) } \\
\hline $\begin{array}{r}\text { DEMAND } \\
\text { LOAD (kW) }\end{array}$ & \#WG & WG (kW) & DG (kW) & $\begin{array}{r}\text { FUEL DEMAND } \\
\text { (gal/hr) }\end{array}$ & $\begin{array}{r}\text { FUEL USED } \\
\text { (gal/hr) }\end{array}$ & $\begin{array}{r}\text { FUEL SAVED } \\
\text { (gal/hr) }\end{array}$ \\
\hline 800 & 1 & 19.5 & 780.5 & 51.6 & 50.3 & 1.3 \\
\cline { 2 - 7 } & 2 & 39.0 & 761.0 & 51.6 & 48.8 & 2.8 \\
\cline { 2 - 7 } & 3 & 58.5 & 741.5 & 51.6 & 47.7 & 3.9 \\
\cline { 2 - 7 } & 4 & 78.0 & 722.0 & 51.6 & 46.7 & 4.9 \\
\hline
\end{tabular}

\begin{tabular}{|r|r|r|r|r|r|r|}
\cline { 2 - 7 } \multicolumn{1}{c|}{ WIND SPEED (15 mph) } \\
\hline $\begin{array}{r}\text { DEMAND } \\
\text { LOAD (kW) }\end{array}$ & \#WG & WG (kW) & DG (kW) & $\begin{array}{r}\text { FUEL DEMAND } \\
\text { (gal/hr) }\end{array}$ & $\begin{array}{r}\text { FUEL USED } \\
\text { (gal/hr) }\end{array}$ & $\begin{array}{r}\text { FUEL SAVED } \\
\text { (gal/hr) }\end{array}$ \\
\hline 800 & 1 & 57.1 & 742.9 & 51.6 & 47.8 & 3.8 \\
\cline { 2 - 7 } & 2 & 114.2 & 685.8 & 51.6 & 44.8 & 6.8 \\
\cline { 2 - 7 } & 3 & 171.3 & 628.7 & 51.6 & 41.7 & 9.9 \\
\cline { 2 - 7 } & 4 & 228.4 & 571.6 & 51.6 & 38.6 & 13.0 \\
\hline
\end{tabular}

\begin{tabular}{|r|r|r|r|r|r|r|}
\cline { 2 - 7 } \multicolumn{1}{c|}{} & \multicolumn{7}{|c|}{ WIND SPEED (20 $\mathbf{m p h})$} \\
\hline $\begin{array}{r}\text { DEMAND } \\
\text { LOAD (kW) }\end{array}$ & \#WG & WG (kW) & DG (kW) & $\begin{array}{r}\text { FUEL DEMAND } \\
\text { (gal/hr) }\end{array}$ & $\begin{array}{r}\text { FUEL USED } \\
\text { (gal/hr) }\end{array}$ & $\begin{array}{r}\text { FUEL SAVED } \\
(\mathrm{gal} / \mathrm{hr})\end{array}$ \\
\hline 800 & 1 & 118.7 & 681.3 & 51.6 & 44.5 & 7.1 \\
\cline { 2 - 7 } & 2 & 237.4 & 562.6 & 51.6 & 38.2 & 13.4 \\
\cline { 2 - 7 } & 3 & 356.1 & 443.9 & 51.6 & 31.8 & 19.8 \\
\cline { 2 - 7 } & 4 & 474.8 & 325.2 & 51.6 & 25.4 & 26.2 \\
\hline
\end{tabular}

\begin{tabular}{|r|r|r|r|r|r|r|}
\cline { 2 - 7 } \multicolumn{1}{c|}{ WIND SPEED (25 mph) } \\
\hline $\begin{array}{r}\text { DEMAND } \\
\text { LOAD (kW) }\end{array}$ & \#WG & WG (kW) & DG (kW) & $\begin{array}{r}\text { FUEL DEMAND } \\
\text { (gal/hr) }\end{array}$ & $\begin{array}{r}\text { FUEL USED } \\
\text { (gal/hr) }\end{array}$ & $\begin{array}{r}\text { FUEL SAVED } \\
\text { (gal/hr) }\end{array}$ \\
\hline 800 & 1 & 171.4 & 628.6 & 51.6 & 41.7 & 9.9 \\
\cline { 2 - 7 } & 2 & 342.8 & 457.2 & 51.6 & 32.5 & 19.1 \\
\cline { 2 - 7 } & 3 & 514.2 & 285.8 & 51.6 & 23.5 & 28.1 \\
\cline { 2 - 7 } & 4 & 685.6 & 114.4 & 51.6 & 16.6 & 35.0 \\
\hline
\end{tabular}

\begin{tabular}{|r|r|r|r|r|r|r|}
\cline { 2 - 7 } \multicolumn{1}{c|}{ WIND SPEED (30 $\mathbf{~ m p h}$ ) } \\
\hline $\begin{array}{r}\text { DEMAND } \\
\text { LOAD (kW) }\end{array}$ & \#WG & WG (kW) & DG (kW) & $\begin{array}{r}\text { FUEL DEMAND } \\
\text { (gal/hr) }\end{array}$ & $\begin{array}{r}\text { FUEL USED } \\
\text { (gal/hr) }\end{array}$ & $\begin{array}{r}\text { FUEL SAVED } \\
\text { (gal/hr) }\end{array}$ \\
\hline 800 & 1 & 206.0 & 594.0 & 51.6 & 39.8 & 11.8 \\
\cline { 2 - 7 } & 2 & 412.0 & 388.0 & 51.6 & 28.8 & 22.8 \\
\cline { 2 - 7 } & 3 & 618.0 & 182.0 & 51.6 & 19.3 & 32.3 \\
\cline { 2 - 7 } & 4 & 824.0 & 126.0 & 51.6 & 17.1 & 34.5 \\
\hline
\end{tabular}

\begin{tabular}{|r|r|r|r|r|r|r|}
\cline { 2 - 7 } \multicolumn{1}{c|}{ WIND SPEED (35 mph) } \\
\hline $\begin{array}{r}\text { DEMAND } \\
\text { LOAD (kW) }\end{array}$ & \#WG & WG (kW) & DG (kW) & $\begin{array}{r}\text { FUEL DEMAND } \\
\text { (gal/hr) }\end{array}$ & $\begin{array}{r}\text { FUEL USED } \\
\text { (gal/hr) }\end{array}$ & $\begin{array}{r}\text { FUEL SAVED } \\
\text { (gal/hr) }\end{array}$ \\
\hline 800 & 1 & 227.0 & 573.0 & 51.6 & 38.7 & 12.9 \\
\cline { 2 - 7 } & 2 & 454.0 & 346.0 & 51.6 & 26.6 & 25.0 \\
\cline { 2 - 7 } & 3 & 681.0 & 119.0 & 51.6 & 16.8 & 34.8 \\
\cline { 2 - 7 } & 4 & 908.0 & 117.0 & 51.6 & 16.7 & 34.9 \\
\hline
\end{tabular}

\begin{tabular}{|r|r|r|r|r|r|r|}
\cline { 2 - 7 } \multicolumn{1}{c|}{ WIND SPEED (40 $\mathbf{~ m p h}$ ) } \\
\hline $\begin{array}{r}\text { DEMAND } \\
\text { LOAD (kW) }\end{array}$ & \#WG & WG (kW) & DG (kW) & $\begin{array}{r}\text { FUEL DEMAND } \\
\text { (gal/hr) }\end{array}$ & $\begin{array}{r}\text { FUEL USED } \\
\text { (gal/hr) }\end{array}$ & $\begin{array}{r}\text { FUEL SAVED } \\
\text { (gal/hr) }\end{array}$ \\
\hline 800 & 1 & 230.0 & 570.0 & 51.6 & 38.5 & 13.1 \\
\cline { 2 - 7 } & 2 & 460.0 & 340.0 & 51.6 & 26.2 & 25.4 \\
\cline { 2 - 7 } & 3 & 690.0 & 110.0 & 51.6 & 16.4 & 35.2 \\
\cline { 2 - 7 } & 4 & 920.0 & 105.0 & 51.6 & 16.2 & 35.4 \\
\hline
\end{tabular}




\section{NREL: SAN CLEMENTE ISLAND}

$3 \mathrm{gal} / 75 \mathrm{~kW}=$

$4 \mathrm{gal} / 75 \mathrm{~kW}=$

$5 \mathrm{gal} / 75 \mathrm{~kW}=$

$6 \mathrm{gal} / 75 \mathrm{~kW}=$

$7 \mathrm{gal} / 75 \mathrm{~kW}=$
0.04

0.053333

0.066667

0.08

0.093333

$\begin{array}{llll}\text { (1) } W G & \text { (2) WG } & \text { (3) WG } & \text { (4) WG }\end{array}$

$\begin{array}{rrrrr}10 & 1.3 & 2.8 & 3.9 & 4.9 \\ 15 & 3.8 & 6.8 & 9.9 & 13.0 \\ 20 & 7.1 & 13.4 & 19.8 & 26.2 \\ 25 & 9.9 & 19.1 & 28.1 & 35.0 \\ 30 & 11.8 & 22.8 & 32.3 & 34.5 \\ 35 & 12.9 & 25.0 & 34.8 & 34.9 \\ 40 & 13.1 & 25.4 & 35.2 & 35.4\end{array}$

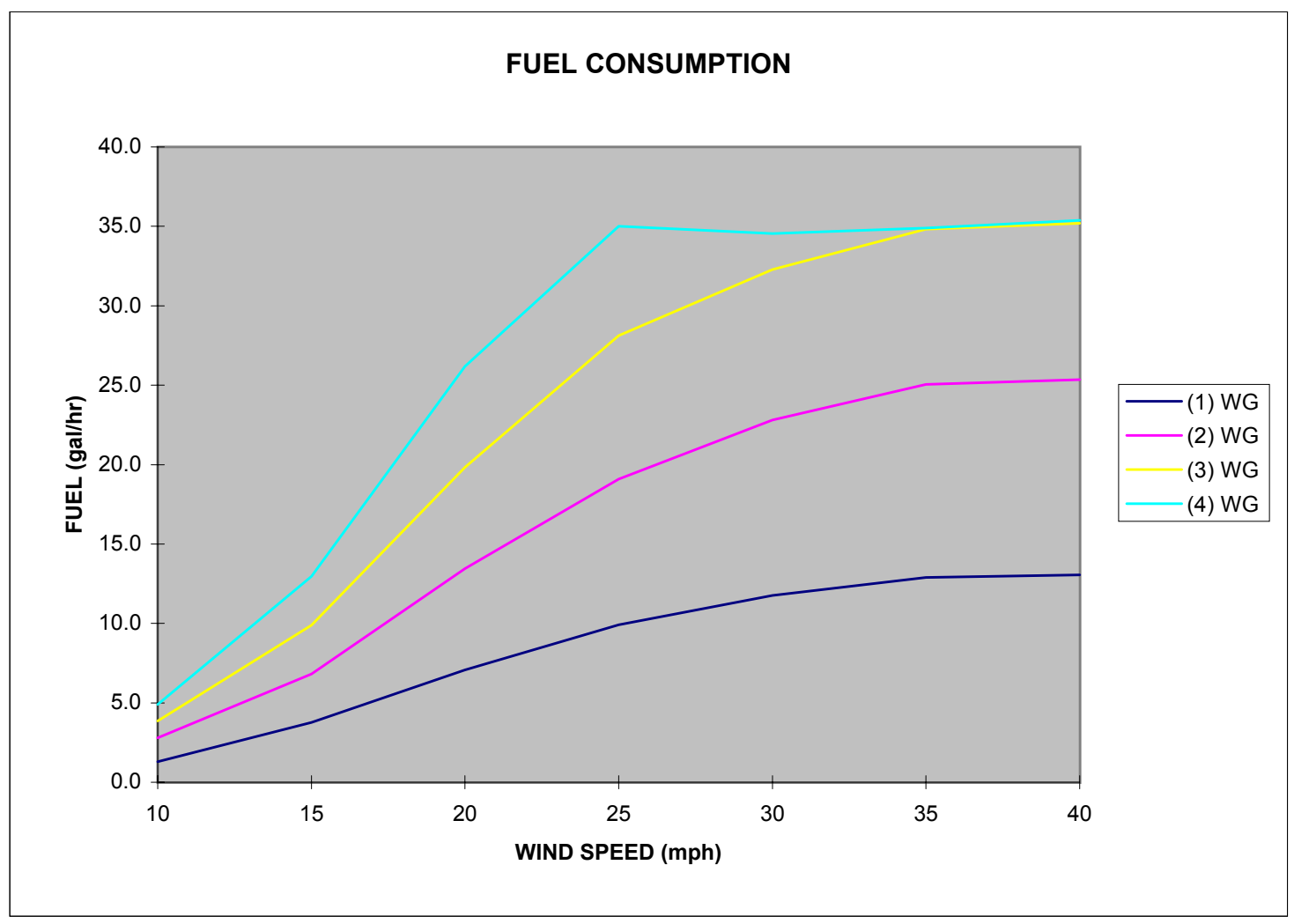


POWER CURVE DATA

WIND GENERATOR: MODEL 225kW

\begin{tabular}{|r|r|r|}
\hline WIND & WIND & ELECTRIC \\
SPEED & SPEED & POWER \\
\hline $\mathrm{m} / \mathrm{s}$ & $\mathrm{Mph}$ & $\mathrm{kWh}$ \\
\hline 3.0 & 6.7 & 0.0 \\
\hline 4.0 & 8.9 & 6.8 \\
\hline 5.0 & 11.2 & 19.5 \\
\hline 6.0 & 13.4 & 31.2 \\
\hline 7.0 & 15.7 & 57.1 \\
\hline 8.0 & 17.9 & 87.6 \\
\hline 9.0 & 20.1 & 118.7 \\
\hline 10.0 & 22.4 & 149.6 \\
\hline 11.0 & 24.6 & 171.4 \\
\hline 12.0 & 26.8 & 189.3 \\
\hline 13.0 & 29.1 & 206.0 \\
\hline 14.0 & 31.3 & 216.0 \\
\hline 15.0 & 33.6 & 224.0 \\
\hline 16.0 & 35.8 & 227.0 \\
\hline 17.0 & 38.0 & 229.0 \\
\hline 18.0 & 40.3 & 230.0 \\
\hline 19.0 & 42.5 & 225.0 \\
\hline 20.0 & 44.7 & 215.0 \\
\hline 21.0 & 47.0 & 212.0 \\
\hline 22.0 & 49.2 & 210.0 \\
\hline 23.0 & 51.5 & 210.0 \\
\hline 24.0 & 53.7 & 210.0 \\
\hline 25.0 & 55.9 & 210.0 \\
\hline$>25$ & 0.0 & 0.0 \\
\hline & & \\
\hline
\end{tabular}

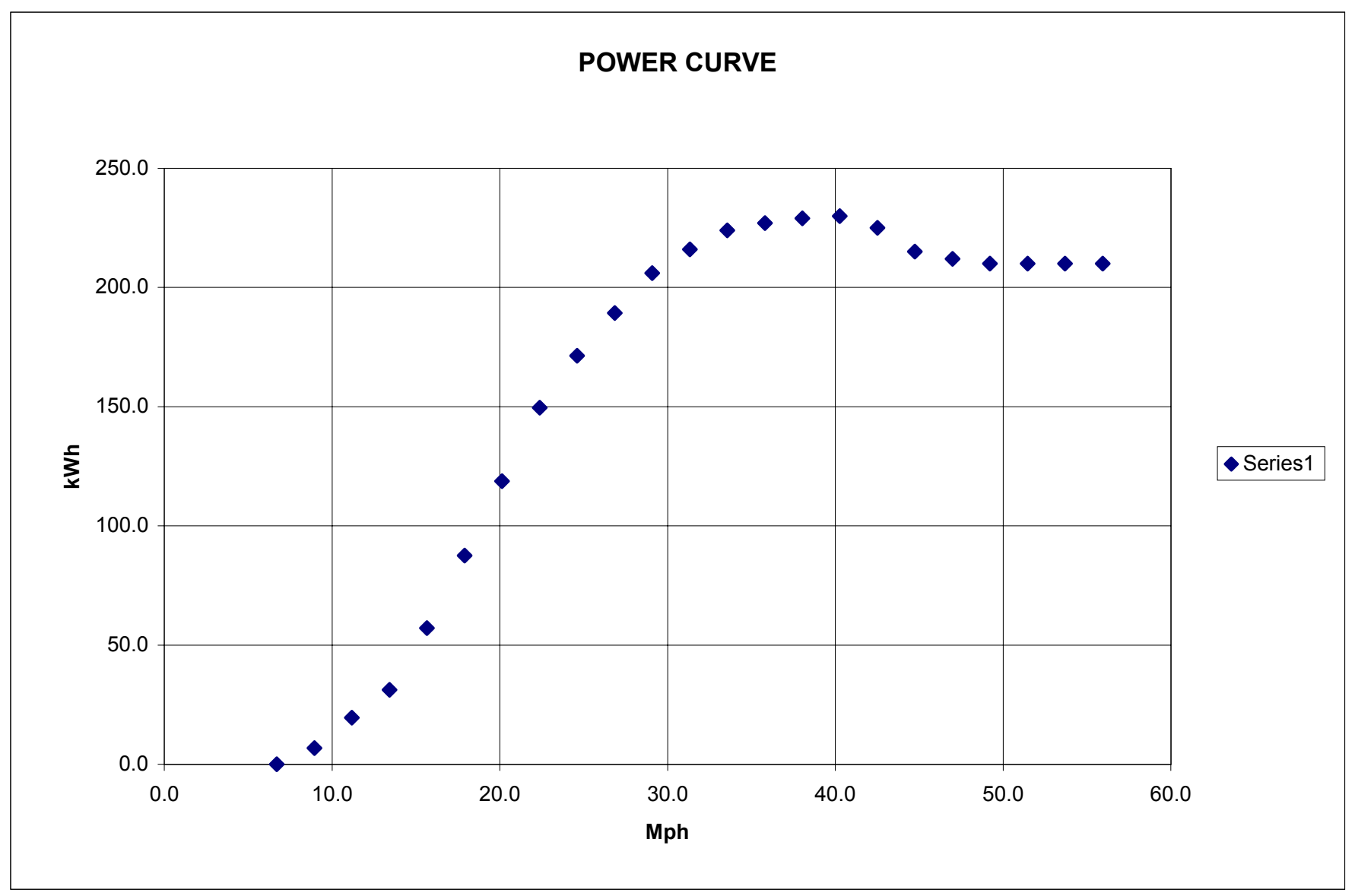

$\mathrm{Mph}=(\mathrm{m} / \mathrm{s})^{\star}(2.237)$ 
PERFORMANCE CURVE DATA

DETROIT DIESEL GENERATOR: MODEL 16V-149TI SCCC

\begin{tabular}{|r|r|r|}
\hline POWER & POWER & FUEL \\
\hline $\mathrm{bph}$ & $\mathrm{kW}$ & $\mathrm{gal} / \mathrm{hr}$ \\
\hline 0.0 & 0.0 & 12.0 \\
\hline 100.0 & 74.6 & 15.0 \\
\hline 200.0 & 149.2 & 18.0 \\
\hline 300.0 & 223.8 & 21.0 \\
\hline 400.0 & 298.4 & 24.0 \\
\hline 500.0 & 373.0 & 28.0 \\
\hline 600.0 & 447.6 & 32.0 \\
\hline 700.0 & 522.2 & 36.0 \\
\hline 800.0 & 596.8 & 40.0 \\
\hline 900.0 & 671.4 & 44.0 \\
\hline $1,000.0$ & 746.0 & 48.0 \\
\hline $1,100.0$ & 820.6 & 53.0 \\
\hline $1,200.0$ & 895.2 & 58.0 \\
\hline $1,300.0$ & 969.8 & 63.0 \\
\hline $1,400.0$ & $1,044.4$ & 68.0 \\
\hline $1,500.0$ & $1,119.0$ & 73.0 \\
\hline $1,600.0$ & $1,193.6$ & 78.0 \\
\hline $1,700.0$ & $1,268.2$ & 84.0 \\
\hline $1,800.0$ & $1,342.8$ & 90.0 \\
\hline $1,900.0$ & $1,417.4$ & 96.0 \\
\hline $2,000.0$ & $1,492.0$ & 102.0 \\
\hline $2,100.0$ & $1,566.6$ & 108.0 \\
\hline $2,200.0$ & $1,641.2$ & 114.0 \\
\hline $2,300.0$ & $1,715.8$ & 121.0 \\
\hline & &
\end{tabular}

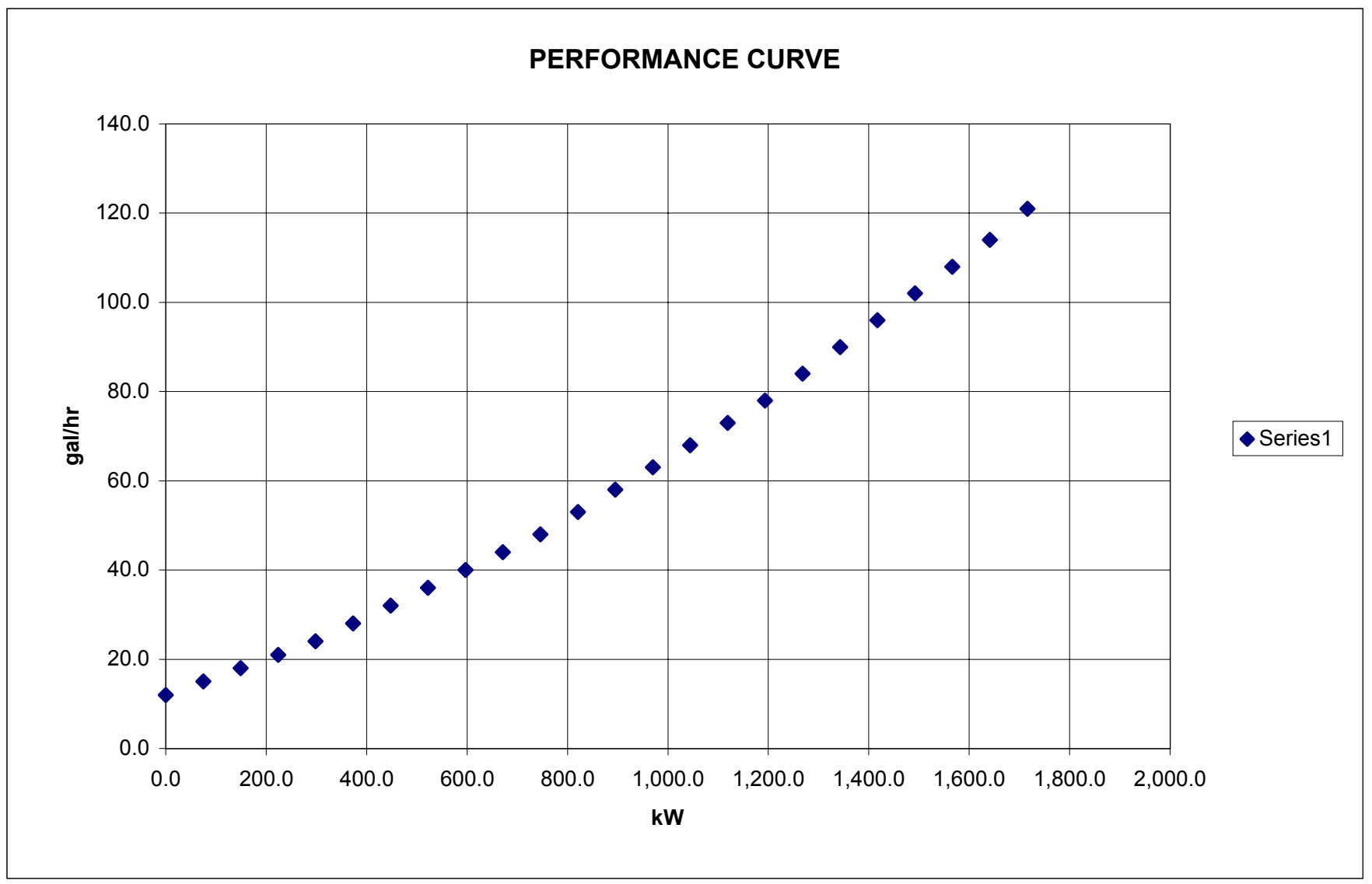

$\mathrm{kW}=\mathrm{bhp}^{*} 0.746$ 


\section{Graphs Chart 1}

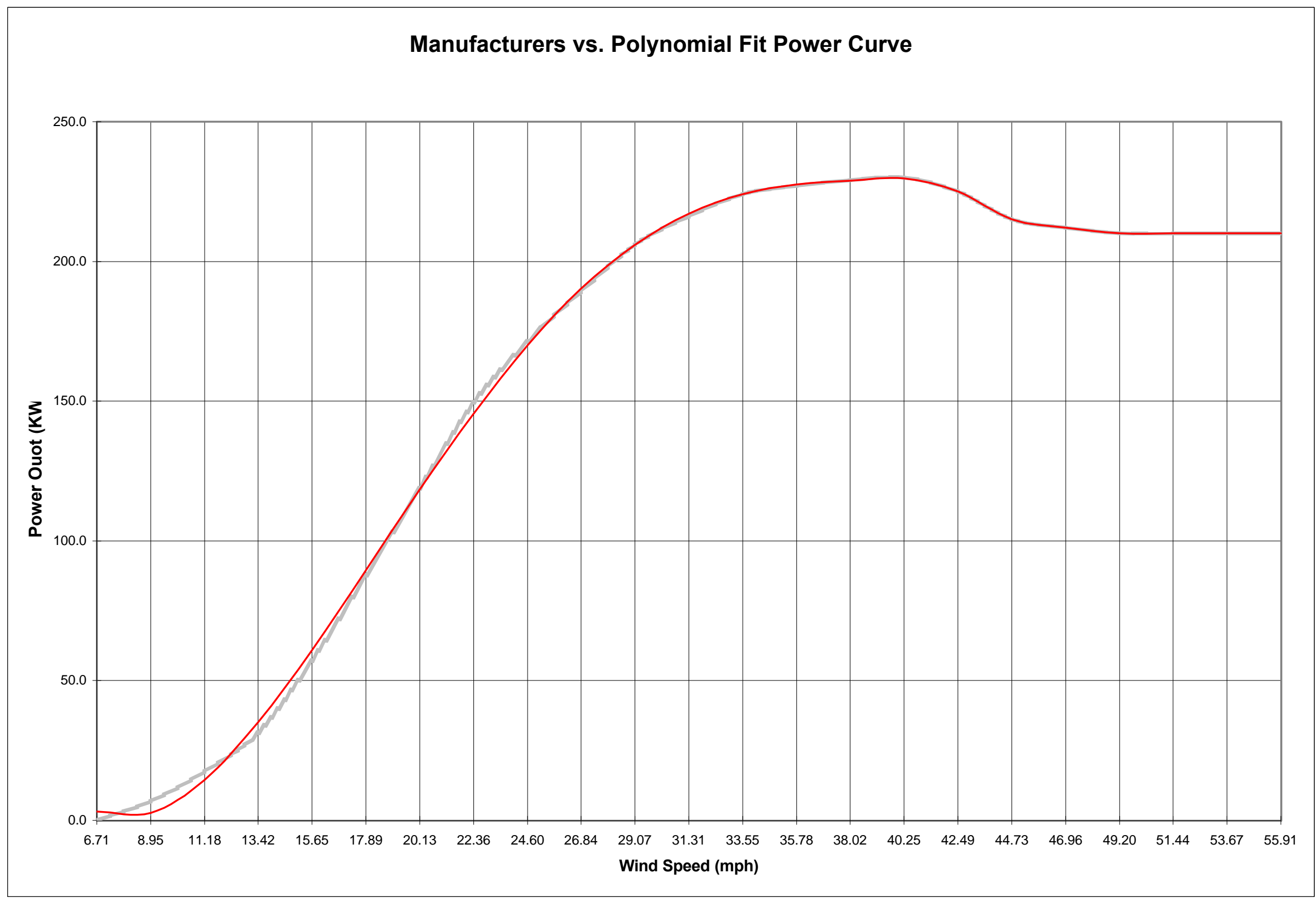

Page 1 
Graphs Chart 3

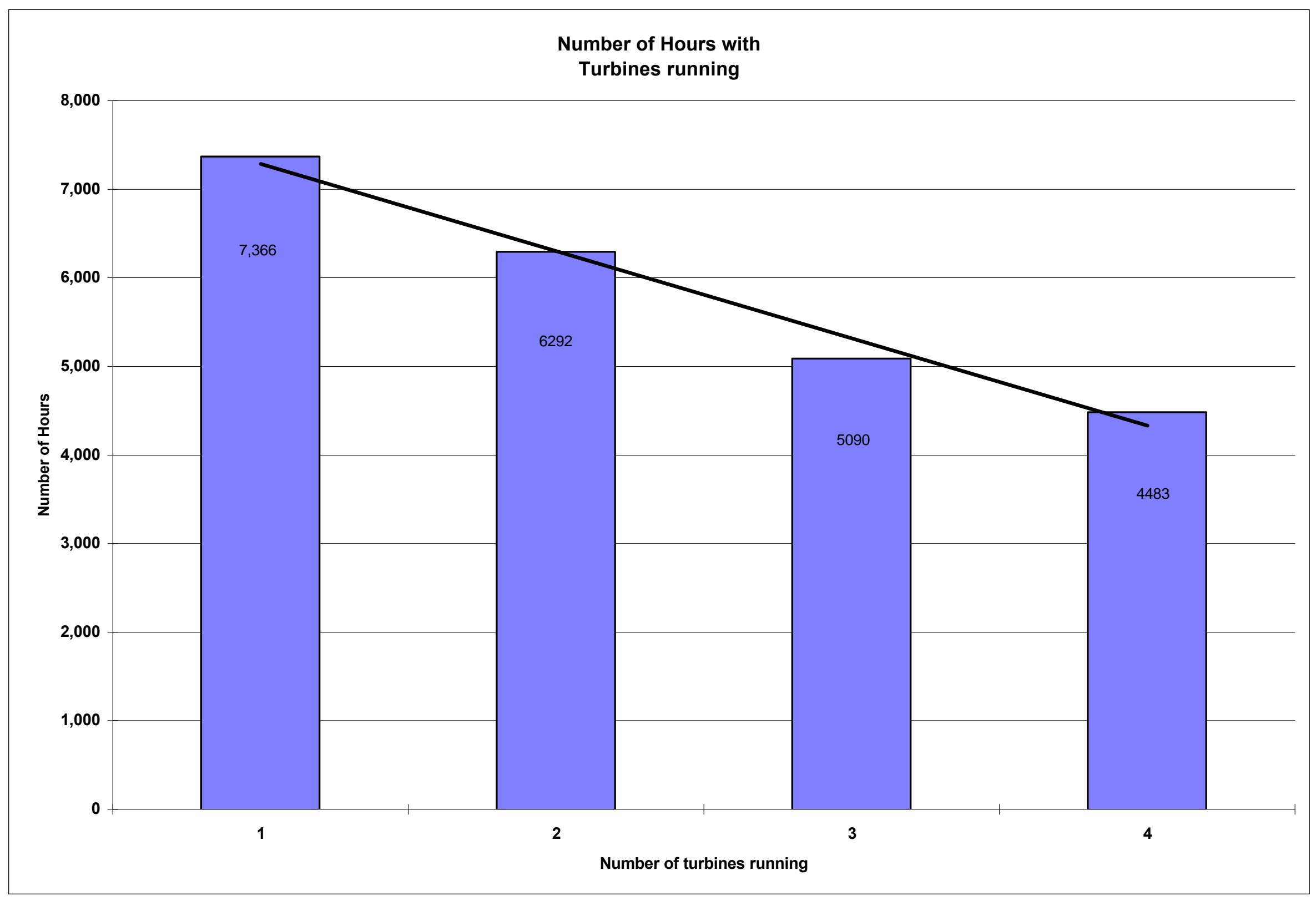

Page 1 


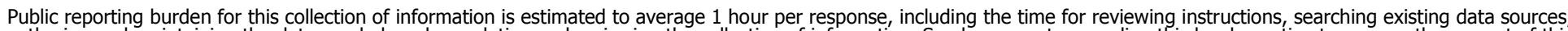

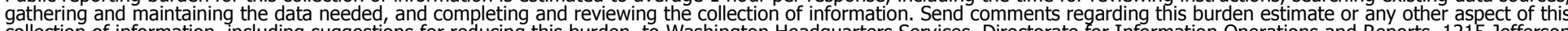

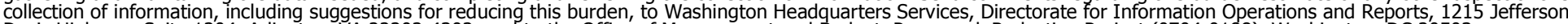

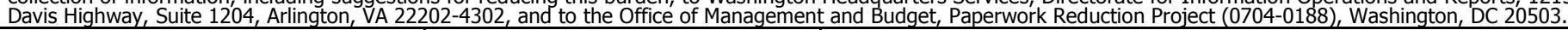
1. AGENCY USE ONLY (Leave blank)
2. REPORT DATE July 1999
3. REPORT TYPE AND DATES COVERED
Subcontract Report

4. TITLE AND SUBTITLE

Performance and Economics of a Wind-Diesel Hybrid Energy System: Naval Air Landing Field,

San Clemente Island, California

5. FUNDING NUMBERS

WE903030

6. $\operatorname{AUTHOR}(\mathrm{S})$

Ed McKenna, NREL

Timothy L. Olsen, Tim Olsen Consulting

7. PERFORMING ORGANIZATION NAME(S) AND ADDRESS(ES)

National Renewable Energy Laboratory

1617 Cole Blvd.

Golden, CO 80401-3393
Tim Olsen Consulting

1428 S. Humboldt

Denver, Colorado 80210
8. PERFORMING ORGANIZATION REPORT NUMBER

9. SPONSORING/MONITORING AGENCY NAME(S) AND ADDRESS(ES)

National Renewable Energy Laboratory

1617 Cole Blvd.

Golden, CO 80401-3393

10. SPONSORING/MONITORING

AGENCY REPORT NUMBER

SR-540-24663

\section{SUPPLEMENTARY NOTES}

NREL Technical Monitor: Ed McKenna

12a. DISTRIBUTION/AVAILABILITY STATEMENT

National Technical Information Service

12b. DISTRIBUTION CODE

U.S. Department of Commerce

5285 Port Royal Road

Springfield, VA 22161

13. ABSTRACT (Maximum 200 words)

This report provides an overview of the wind resource, economics and operation of the recently installed wind turbines in conjunction with diesel power for the Naval Air Landing Field (NALF), San Clemente Island (SCI), California Project.

The primary goal of the SCI wind power system is to operate with the existing diesel power plant and provide equivalent or better power quality and system reliability than the existing diesel system. The wind system is also intended to reduce, as far as possible, the use of diesel fuel and the inherent generation of nitrogen-oxide emissions and other pollutants.

The first two NM 225/30 225kW wind turbines were installed and started shake-down operations on February 5, 1998. This report describes the initial operational data gathered from February 1998 through January 1999, as well as the SCI wind resource and initial cost of energy provided by the wind turbines on SCI. In support of this objective, several years of data on the wind resources of San Clemente Island were collected and compared to historical data. The wind resource data were used as input to economic and feasibility studies for a wind-diesel hybrid installation for SCI.

14. SUBJECT TERMS

wind power, wind turbines, wind power and military applications, wind-diesel applications, Federal Energy Management Program

17. SECURITY CLASSIFICATION OF REPORT
18. SECURITY CLASSIFICATION OF THIS PAGE
19. SECURITY CLASSIFICATION OF ABSTRACT
15. NUMBER OF PAGES

16. PRICE CODE

20. LIMITATION OF ABSTRACT

UL 